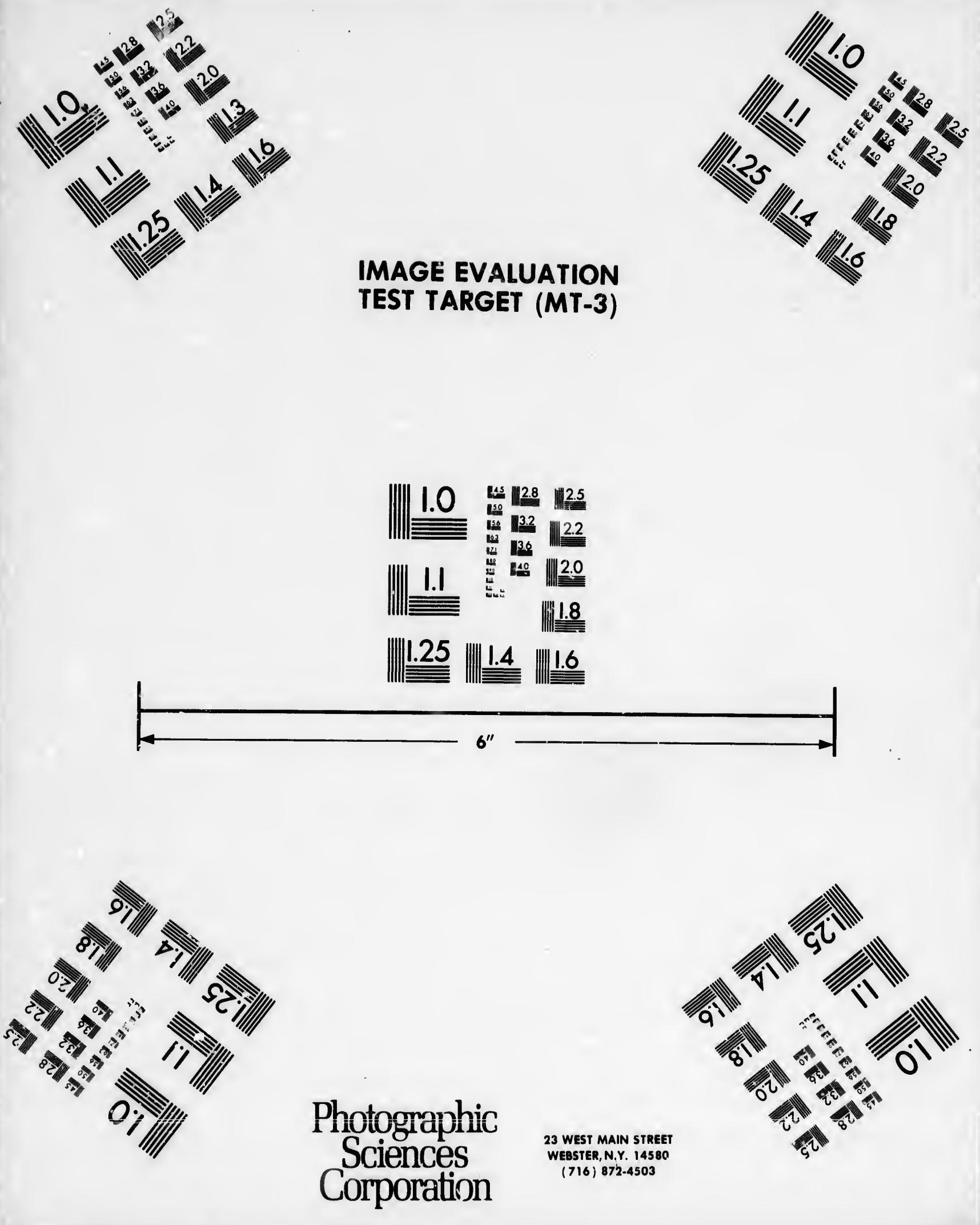




\section{CIHM/ICMH Microfiche Series.}

\section{CIHM/ICMH Collection de microfiches.}

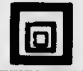

Canadian Institute for Historical Microreproductions / Institut canadien de microreproductions historiques
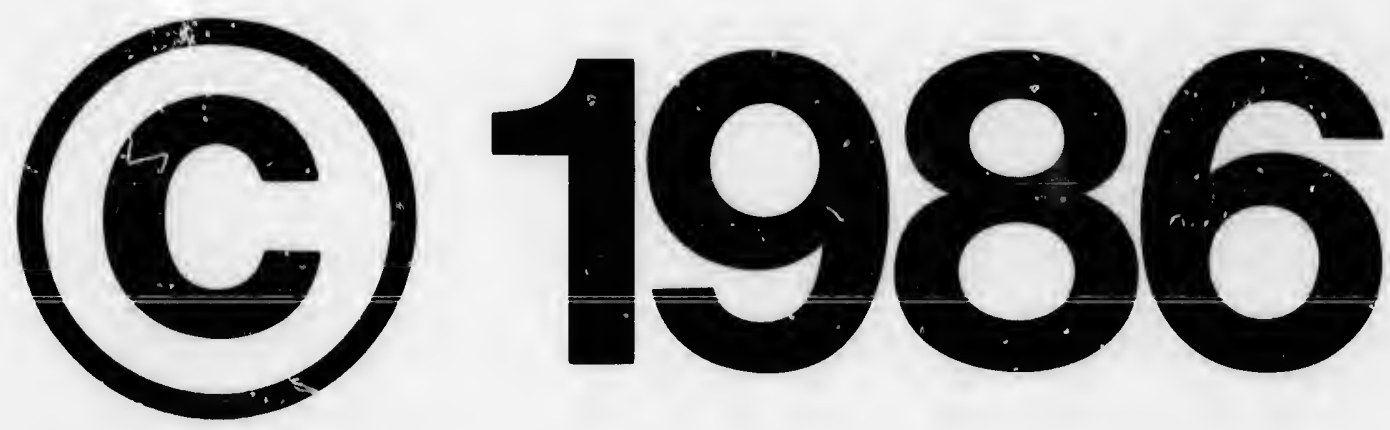
The Instltute hes ettempted to obtain the best original copy available for filming. Fantures of this copy which moy be blbliographlcally unique. whlch may eltar any of the images in the reproduction, or which may significantly change the usuel method of filming, are checked below.

Coioured covars/

Cousverture de couisur

Covers damaged/

Couverture andommagie

Covers restored and/or iaminated/

Couverture restaurde ot/ou peilicuide

Cover tltle missing/

Le titre de couverture manque

Coloured meps/

Cartes géographiques en coulour

Coloured ink (i.e. other than blue or black)/

Encre de couleur (i.e. autre que biaus ou noire)

Coloured piates and/or iiiustrations/

Planches of ou iilustrations en couloup

Bound with other materiai/

Reiib avec d'autres documents

Tight binding may cause shadows or distortion along interior margin/

La rs liure serróe peut causer de i'ambre ou de ia distorsion is long de ia marge intérieure

Blank leaves added during restoration may appeer within the texs. Whenaver possible, these heve been omltted from filming/

II se paut que cartalnee pagas blanches ejoutóes lore d'une restauration apparaissent dens le texte. mais, iorsque ceia dtait possibie, ces pages n'ont pas dté fiimbes.

Additlonai comments:/

Commentairses suppiémentaires.
L'Inatitut a microfilmo le mailleur exemplaire qu'ii lul a été posslble de se procurer. Lez détails de cet exempleire qui sont peut-atre uniques du point de vue bibllographiqua, qui peuvent modifier une imege reprodulte, ou qui peuvent exiger une modification dans la móthode normale de filmage sont indlqubs cl-dessous.

Coioured pagess'

Pagos de coulour

Page damaged/

Pages endommagies

Pages reatored end/or laminated/

Pages restaurdes et/ou pelliculdes

Pages discoloured, stained or foxed/

Pages décolorées, tachetées ou piquées

Pages detached/

Pager dótachíes

Showthrough/

Transparence

Quellty of print varies/

Quatite indgale de l'impression

inciudas supplementary material/

Comprend du matóriai suppiémentaire

Oniy edition availabie/

Souie dodition dlsponible

Pages wholly or partially obscured by errata slips, tissues, otc. have been refiimed to ensure the best possible image/

Les pages totelament ou partiellement obscurcies par un feuillet d'errata, une pelure. etc.. ont été filmbes à nouveeu de façon à obtenir ia meillaure image possible.

This item is filmed at the reduction ratio chocked below/ Ce document ess filmó au teux de róduction indiqué ci-dessous.

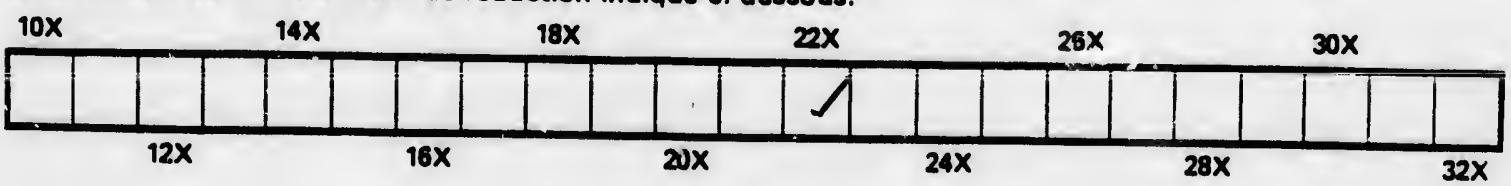


The copy filmed here has been reproduced thanks to the generosity of:

\section{Library \\ Agriculture Canada}

The imeges appearing here are the best quelity posslbie considering the condition and legibility of the original copy end in keeping with the filming contract speciflcations.

Originai copies in printed paper covers are filmed beginning with the front cover and ending on the last page with a printed or lilustrated impression, or the back cover when appropriate. Aii other originei copies are flimed buginning on the first page with a printed or iliustrated Impression, and ending on the iast page with a printed or illustrated impression.

The iast recorded frame on each microfiche shali contain the symboi $\rightarrow$ Imeaning "CONTINUED"), or the symboi $\nabla$ (meaning "END"). whichever applies.

Maps, plates, charts, etc.. may be filmed at different reduction ratios. Those too iarge to be entirely inciuded in one exposure are filmed beginning in the upper left hand corner, left to rlght and top to bottom, as many frames as required. The foilowing diagrams illustrate the method:
L'exemplaire fllmb fut reproduit grace a la gónórosité da:

\section{Bibliothdque}

Agriculture Canada

Les Images sulvantes ont óté reproduites ovec ie plus grand soin, compte tenu de ia condition ot de la notteté de l'oxemplaire filims, ot en conformité avec les conditlons du contret de filmage.

Les exempiaires originaux dont ia couverture en papier est imprimbe sont filimbs on commencant per le premier piat ot en terminant soit par la derniere page qui comporte une emprolnte d'impression ou d'iliustration, solt par le second piat, seion ie ces. Tous ies autres exémpiaires originoux sont filmes on commençant par ia première page qul comporte une empreinte d'impression ou d'iliustration et en termlnant par ia dernibre page qui comporte une teile empreinte.

Un des symboies suivents apparaîtra sur ia dernlòre imege de chaque miciofiche, selon le cas: ie symboie $\rightarrow$ signifle "A SUIVRE", le symbole $\nabla$ signific "FiN".

Les cartes, pianches, tabieaux, etc., peuvent otre filmés a des taux de róduction differents.

Lorsque ie document est trop grand pour stre reproduit on un seui cliche, il est flimé a partir de l'angle superleur gauche, de gauche droite, et de haut en bas, en prenant le nombre d'images nécessaire. Les diagrammes suivante iilustrent la móthode.
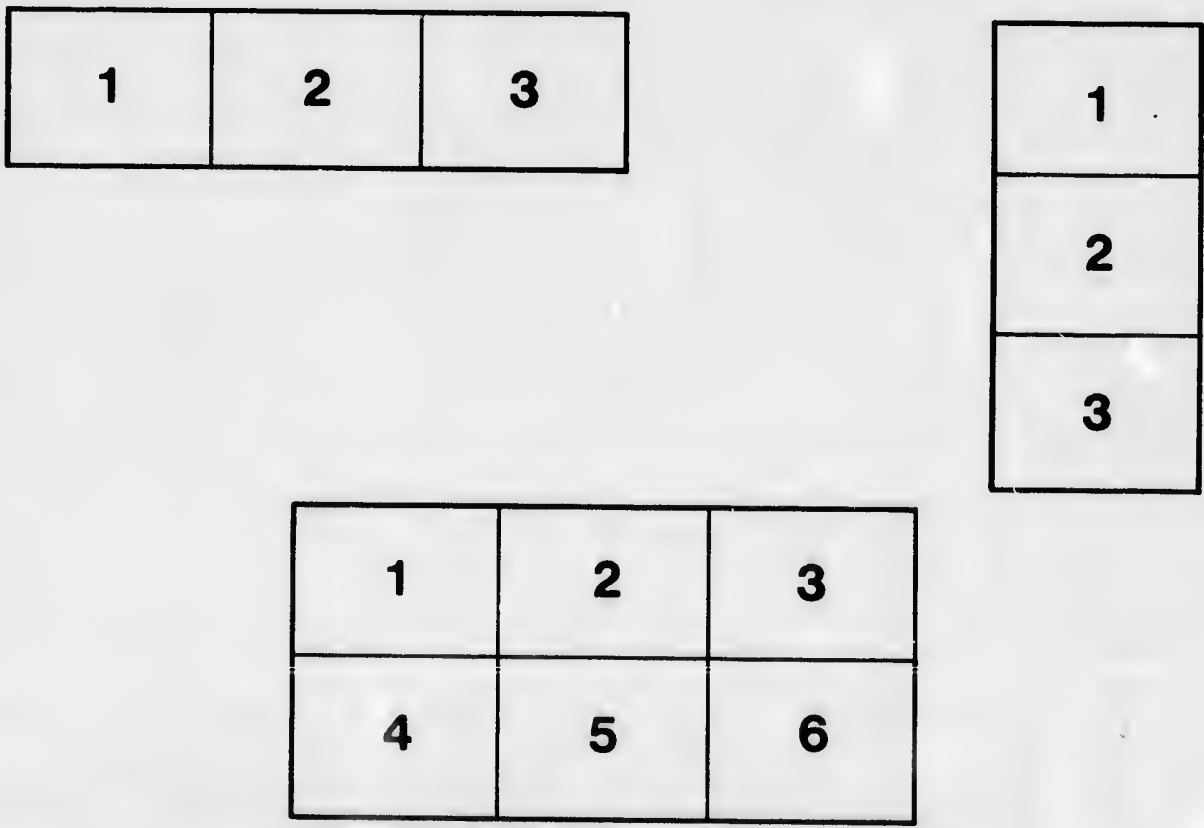
ENGLISH TREES \&? 


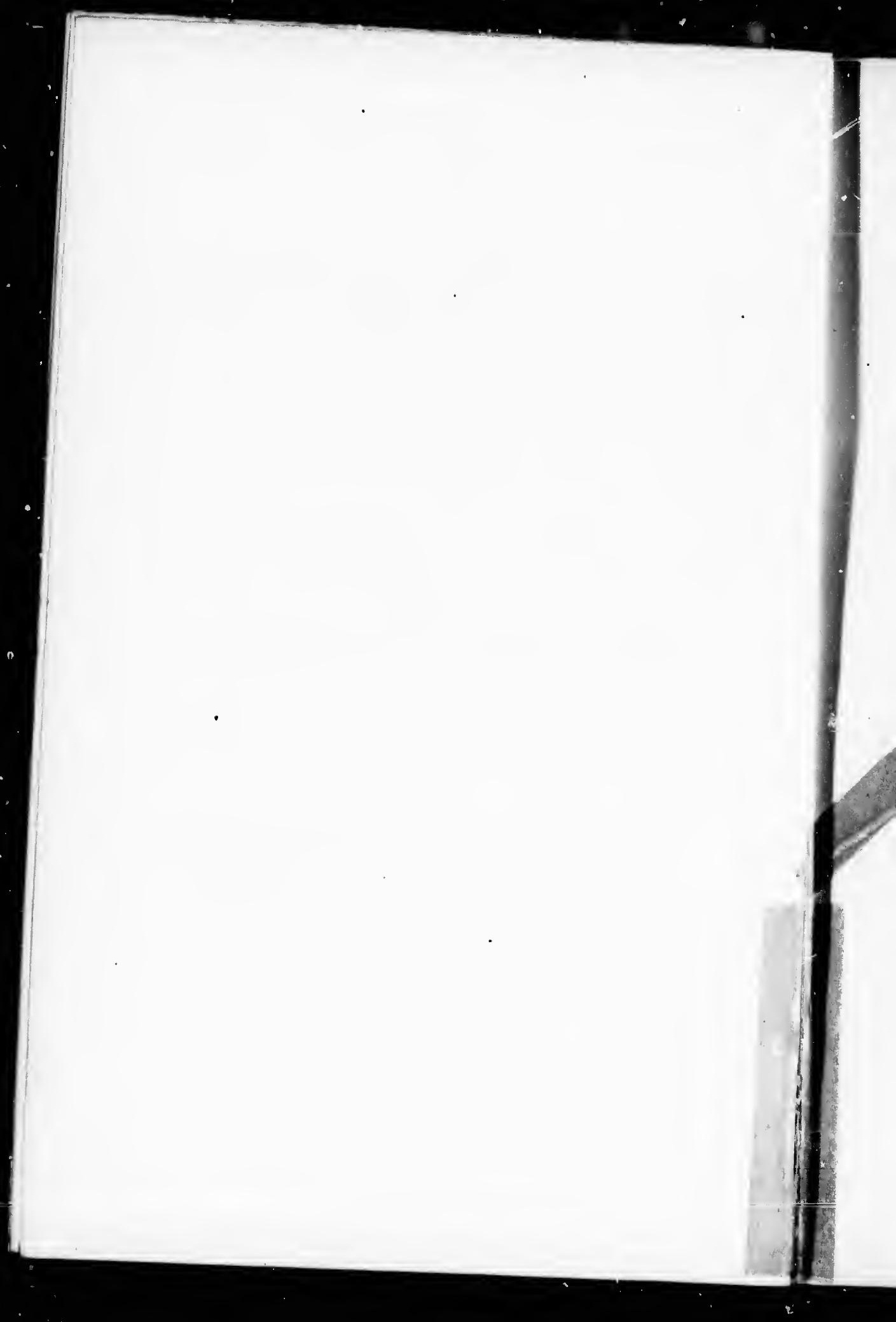




$$
F
$$




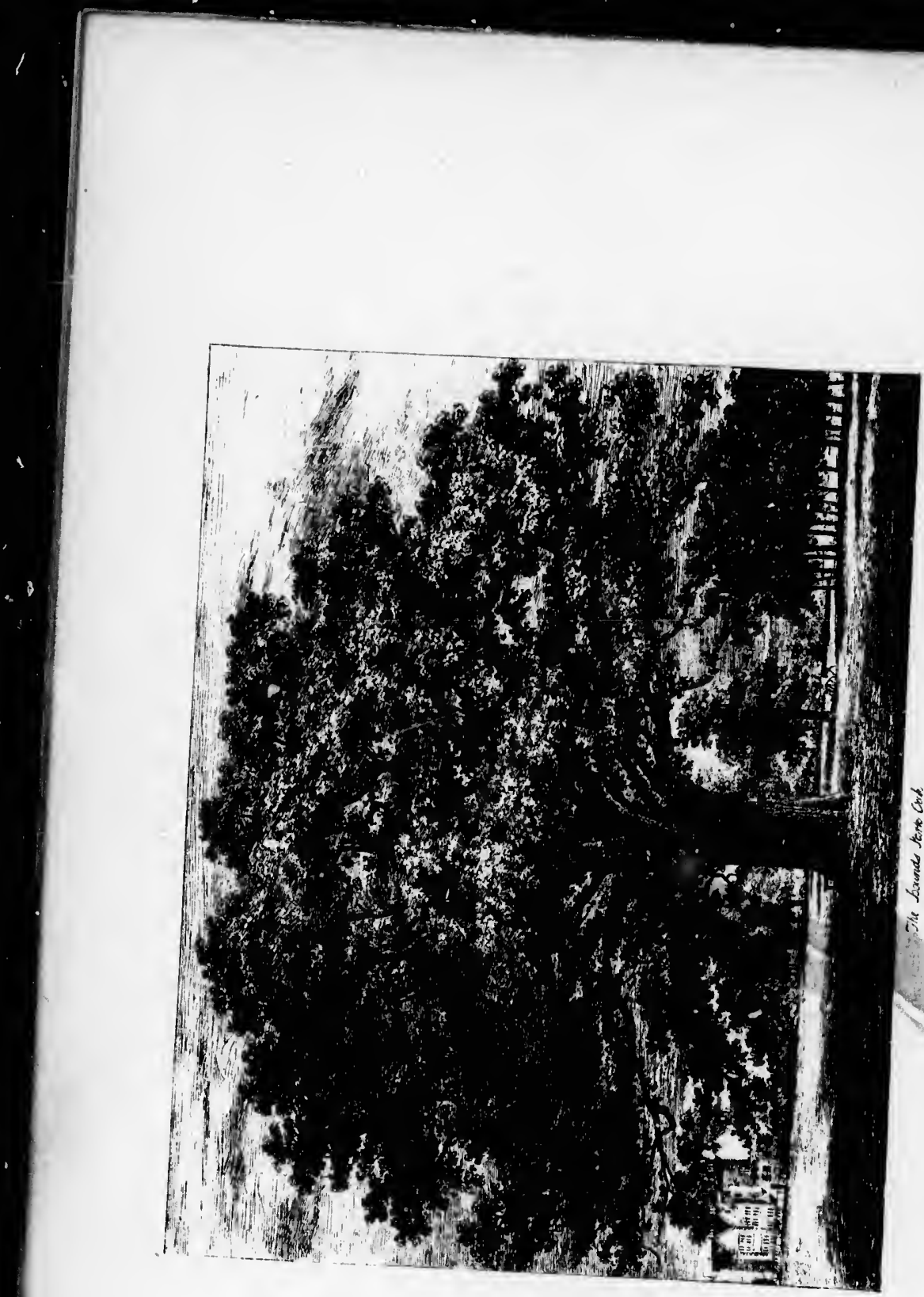




\title{
ENGLISH TREES AND
}

\author{
TREE-PLA NTING
}

BY

WILLIAM H. ABLETT

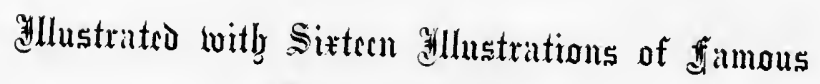
韵istorical Tress.

LONDON
SMITH, ELDER, \& : $0 ., 15$ WATERIOO PLACE
1 isso 


\title{
CONTENTS.
}

\author{
$\rightarrow \infty$ \\ CHAPTER I. \\ BALUBRIOUS INFLUENCE OF TRHES DPON THE ATMOSPHERE-COU- PAGE \\ MERCIAL PRODUCTS OF FIR-TRHES-INTRODUCIOH OE TE- COM- \\ GRODUCTION OF THE LARCH \\ GARDENS AT ROME-NATIVE \\ DUCED TREES-ANCIENT FORESTS

CHAPTER II.

TIRST PRINCIPLES OF PLANTING-SOILS AND BITUATIONB-PALM BUNDAY IN ITALY - DURABILITY OF CEDAR WOOD-BIBLICAL DESCRIPTION OF THE CEDARS OF LEBAYON-THE VIBITS OF TRAVELLERS TO MOUNT IRBANON-OF THE PRINCIPLES OF FERTILITY OF THE SOIL-COBBETT ON TULL-TULL'S PROTEST-THE HUSBANDRY OF VIRGI', GEORGICS-TULL'S ACCOUNT OF HIS INVENTION OF DRILL-COBBITT'S ANTICIPATIONB OF FUTURE CREDIT-COBBETT

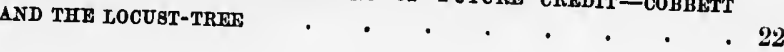

\section{CHAPTER III.}

THE MODERN RAGE FOR PLANTING-TREE-PLANTING AT THE ANTIPODES -CONE-BEARING OR RESINOUS TREFS FIT FOR COLD AND GTEVATED DISTRICTB-FAST-GROWING AND SOFT-WOODED TREES FIT FOR MOIST LAND-BROAD-LEAVED TIMBER TREES SUITABLE FOR LANDSCAPE DECORATION AND GOOD SOIL-TREES AND GHROBS FOR ARBORETICAL DECORATION

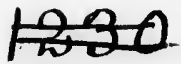




\section{OHAPTER IV.}

CONIFEROUS TREES.

THE BCOTCH PINE-DETERIORATION OF THE SCOTCH PINE-TIEE PINFE OF NORTIERR EUROPE-THE SLIDE OF ALPNACH-PRODUCE OY SCOTCI PINE PLANTATIONS-OBTAINING THE BEEDS-SOWING THE SEED-CULTIVATION-THE CLUSTER IINE, OR PINEASTER : CULTIVATION-THE CORAIOAN PINE: CULTIVATION-THE STONE PINE: CULTIVATION-THE WHITE, OR WEYMOUTH PINE-LUMBERINGLABOURERS LEAVING TIRE 'BIGGEST WHEAT-FAKM. IN AMERICA' FOR
LUMBER WORK .

\section{CHAPTER V.}

CONIFEROUS TREES-continued.

THE GIGAN'IC, OR LAMBERT'S PJ TL-THE LOFTY, OR BHOTAN PINETHE HEAVY-WOODED PINE-LONG-LEAVED INDIAN PINE-DWARF PINE-SPRUCE FIRS: CULTIVATION-THE BLACK SPRUCE FIR- SILVER FIR-BTRASBURG TURPENTINE-CCLTIVATION OF THE SILVER FIR-THE BALM OF GILEAD BILVER FIR . . . . . . 109

\section{CHAPTER VI.}

CONIFEROUS TREES-continued.

THE LARCH-DURABILITY UF LARCH TIMBER-CULTIVATION-CASUALTIES AND DISEASES-THE CEDAR: CULTIVATION-THE INDIAN CEDAR : CULTIVATION .

CHAPTER VII.

CONIFEROUS TREES-Continu'd.

THE YEW-YEW-BOWS-FROISBART'S ACCOUNT OF THE ENGLISH ARCHERS-ANCIENT YEW-TREFS-FANTABTIC SHAPES-CULTIVATION OF THE YEW-TREE-POIBONOUS NATURE OF THE YEW-SPRAY-THE IRISH YEW-THE CYPRESS-ANCIENT CYPRESS-TREE-DOPABIHTY OF CYPRESS TIMBER-CULTIVATION OF THE CYPRE3S-TREE-TIT WHITE CEDAR 
UIIAPTER VIII.

HIOA D-LEA VED TIMBER THEES.

THE OAK-ANCIENT OAKS-UISTORICAL OAKS-SOIL SUITABLE FOK PAGK THE OAK-CULTIVATION-THE TURKEY OAK-THE CORK OAK-TH EVFRG RTEN OAK-NUT-GALL8-THE DYER'S OAK-THE KERM OAK-THE FULHAM OAK-TURNBR'S FVERGREEN OAK-THE LUCOMBE OAK-THE SOARILT OAK . . . . . . 16

\section{CHAPTER IX.}

BROAD-LEA VED TREES-contimued.

THE ASH-CULTIVATION-VAFUETIES-THE BEECH : CULTIVATIONTHF ELM-THE ENGLISH HLM : CULTIVATION-THE WYCH ELM : CULTIVATION-THE HUNTINGDON ELM-THE DU'CH BLM-TIE AMFRICAN ELM-VARIATION OF THE FLM-TIE WEEPING ELM 190

\section{CHAP'TER $X$.}

BROAD-LE'AIED TREES-'OUtimued.

THE MAPLE-THE GREAT MAPLE, OK SYCAMORE: CULTIVATION-THE COMMON MAPLE-THE SUGAR MAPLE-THE NORWAY MAPLE : CULTIVATION-THE RED OR SCARLET MAPLE-THE LARGE-LEAVED MAPLE-THE STRIPED-BARKED MAPLE-THE PLANE-TREE-THF GASTERN PLANE: CULTIVATION-THE WESTERN PLANE : CULTIVALARGE CHFANUT-TRFE : CULTIVATION-THE SPANISH CHESNUT-

\section{CHAPTER XI.}

BROAD.LEAVED TREES-continued,

THE BIRCH-THE COMMON BIRCH: CULTIVATION-THE WEEPING BIRCH-TIIE MAHOGANY BIRCH-THE DWARF BIRCH-THE WALNU'T: CUL'TIVATION--THE BLACK VIRGINIAN WALNUT TRFE-THE LOCUST 'TREE : CUL'THATION-THE LOCUST TREE OF SCRIP'TURE . 234 
viii

CONTENTS.

CHAPTER XII.

FAST-GROUING AND SOFT-WOODED TREES, AFFECTING MOTST STTUATTUNS.

'THi, POPLAR-THE GREY POPLAR : PROPAGATION-THE WHITE POPLAR PACR -THE ASPEN : CULTIVATION-TIE LOMBARDY POPLAR-BLACK ITALIAN POPLAR-ONTARIO POPLAR-THE WILLOW-THE WHITE, - OR HUNTINGDON WILLOW-THE GOAT WILLOW-THE WHEPING WILLOW-THE ALDER: PROPAGATION-THE HORSE CHESNUT : CUI, TIVATION-THE LIME: PROPAGATION

CHAPTER XIII.

THE FORMATION OF PLANTATIONS.

PLANTATIONS AND FCANTING-TRAVELLING SEEDS OF WHEDS-THE TRANSPLANTATION OF LAROE TRFES-8IR HENRY 8TEWART'S METHOD--TRANSPLANTING MACHINE-RFLATIVE VALUE OF TIMBER PLANTATIONS AND ARABLE LAND-USUAL METHODS OF FORMING PLANTATIONS-NOTCH, OR SLIT-PLANTING-CROSS-CUT PIANTING -PIT-PLANTING-TRENCHED GROUND FOR PLANTING-VARIOUS DESCRIPTIONS OF BOILS ALL SUITED FOR PARTICULAR TRTES-ADVANTAGES OF INTERSPERSING CONIFERE IN BROAD-LFAVED PLANTATIONS-PERMANENCY OF HARD-WOODED PLANTATIONS

\section{CIIAPTER XIV.}

ORNAMENTAL PLANTING.

LILAC - LABURNUM : CULTIVATION-ALMOND : CULTIVATION - THE LARGE FRUITED ALMOND-THE HAZTL : CULTIVATION-UNPROFITAILE FILBER' PLANTATION MADE PROFITABLE-CONBTANTINOPLE HAZEL-THE HAWTHORN : CULTIVATION-THE MOUNTAIN ASH : CULTIVATION-THE SERVICF-TRFE-WILD CHERRY: CULTIVATIONAPINDIE-TRFE-THE RLDFR : PROPAGATION . . . . . 392

\section{CHAPTER XV.}

ORNAMENTAL PLANTING-continued.

EVRRGRETNS-THE LA UREL-TITE LAUREL CIHRRY OR COMMON LAURIL: CUITIVATION-THE PORTUGAL LAURIL CHERRY: PROPAGATION - HOLLY : CULTIVATION-BOX: PROPAGATION-PRIVTT - ARBORVITA-JUNIPHR-THE VIRGINIAN JUNIPER-THE SPANISIL JUNIPER-THE COMMON SAVIN . . . . . . . . 351 



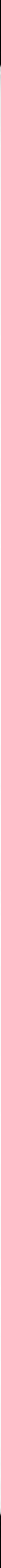




\section{LIST OF ILLUSTRATIONS.}

THE BouNDS PARK OAK . Frontispiece.

The Great Asil at Carnock . . . . . I

The Cedar in the Palace Garden at Enfiel. . . 22

The Moor Park lime Tree . . . . . . 65

The SILVek 1 .. AT Roseneatil . . . . . I2I

Larches at DUNkeld . . . . . . . 126

Tile great yew at fortingal. . . . . . 153

The yew Trees at fountains Abbey . . . . 154

TIE KING'S $O A K$. . . . . . . . . 167

Tile Great Asil at Woburn P'ark . . . . . 190

BeEcil IN KNOLE PARK . . . . . . . . . 195

klam at Crawley in Sussex . . . . . . 200

SYCAMORE AT BISHOPTON, KENFREWSIHRE . . . 208

Black Poplar at bury St Emmunis . . • . 259

kiass at Mongenthl. . . . . . . 351

SCOTCII Fir at DuNMORE. . . . . . . 412 




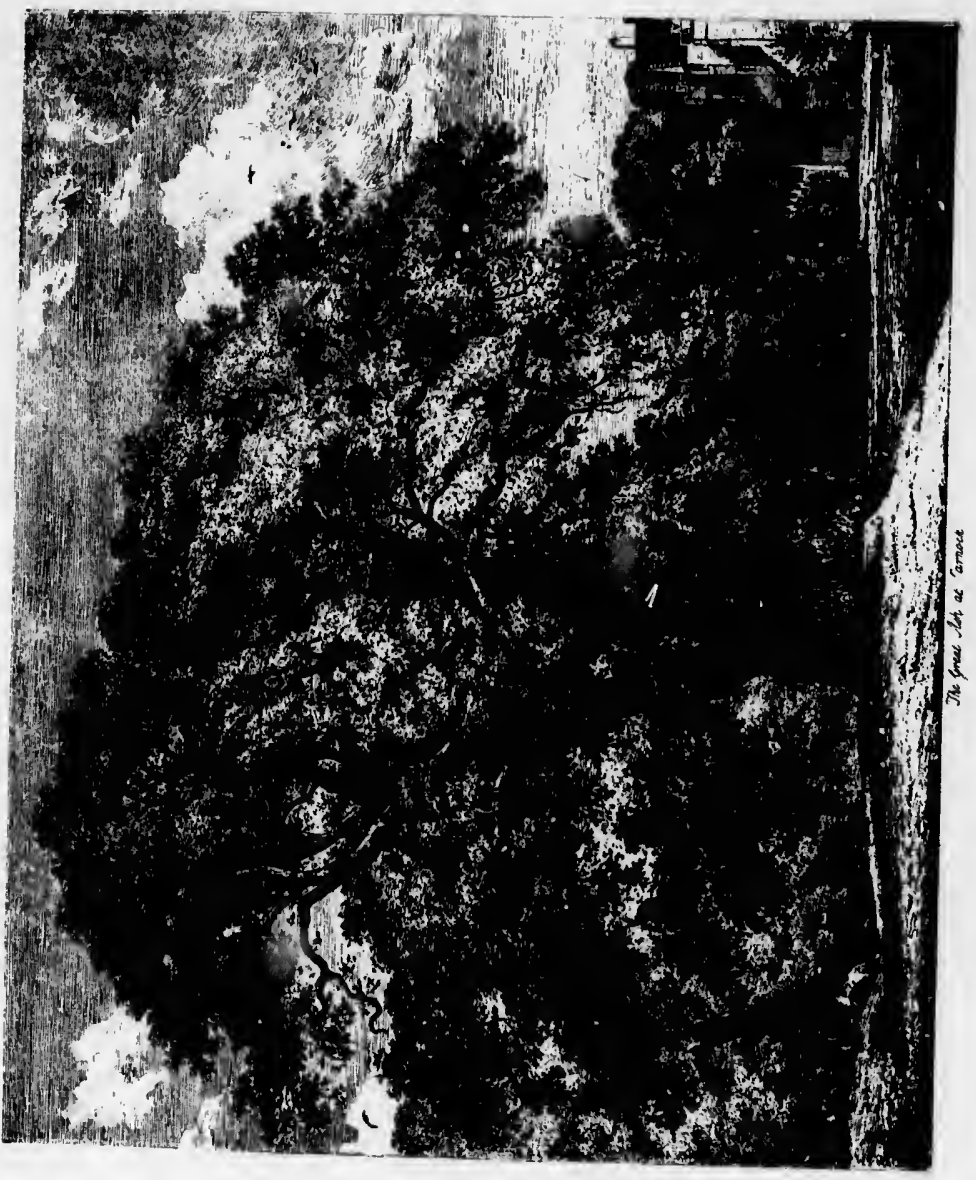




\section{ENGLISH TREES AND TREE-PLANTING.}

\section{CHAPTER I.}

SALUBRIOUS INFLUENCE OF TREES UPON THE ATMOSPHERE-COMMERCIAT PRODUCTS OF FIR-TREES-INTRODUCTION OF THE LARCH INTO SCOTLAND - THE FARNESINA GARDENS AT ROME-NATIVE TREES OF BRITAIN $\triangle N D$ INTRODT JED TREES-ANCIENT FORESTS AND THFIR PRODUCE-ACORNS AS FOOD-MONASTIC GRANTS.

OF late years the salubrious influence of Trees upon the atmosphere has awakened a great deal of public attention, and the subject has come very prominently forward into general notice, not only in England, but throughout most European countries.

The benefit that is to be derived by persons suffering from diseases of the lungs, by residing in the vicinity of pine-forests, has long been known; and advantage has successfully been taken of their invigorating and restorative attributes in America, where parties are often formed for caniping out for a time in them ; while nearer home we have many direct instances furnished to us of the efficacy of arboricultural vegetation in promoting health under certain conditions. Although this particular efficacy of some 
trees in preventing disease and promoting health has been fully recognised, the connection between cause and effect has been, until quite lately, by no means clearly established. The most common idea that used to prevail was, that this purifying influence in nature was due to the evolution of the gas from plants exposed to the air, by the process of slow oxidation; but the proof of the production of this active principle was not forthcoming in a distinct form, and much uncertainty prevailed upon the subject.

Scientific investigation has, however, lately demonstrated that the hygienic principle common to pine-groves and plantations of Eucalyptus globulus, is due to the evolution of the peroxide of hydrogen and camphoric acid; the cause being the volatilisation of naturally secreted oils ; the principle not depending upon the odour of these trets, but upon the 'terpene' or principle of turpentine-the presence of peroxide of hydrogen and camphoraceous substances being referable to the resinous oils secreted by those trees.

The Eucalyptus globulus, or blue-gum-tree, of Australia, has of late acquired a very high reputation for rendering localities habitable which were previously the unhealthy seats of malaria, and on this account had to be abandoned; a striking example of the feverpreventing properties of these trees being furnished by the rehabitation of a deserted cluster of monastic buildings in the most desolate part of the Campagna. 
ealth has

en cause

o means

lea that

uence in

as from

of slow

of this

distinct

pon the

tely de-

imon to

bulus, is

gen and

tilisation

depend-

pon the

sence of

bstances

oy those

of Austion for eviously account e feverirnished conastic npagna.

about three miles from Rome. This was effected about the year 1871, by some Trappist monks, who planted about them groves of the Eucalyptus. For centuries the fever-stricken monks who inhabited these buildings had battled unsuccessfully against the malaria, until towards the close of the last century the monastery was deserted. In Portugal and Algeria are valleys that only a few years since were most unhealthy, but which have now been made quite salubrious by the planting of some of these trees.

Commercial products of Fir-trees. - The resinous produce of fir-trees includes several important articles of commerce, of considerable value. The spruce-fir produces Burgundy pitch, and the best yellow resin. From the silver fir is extracted the Sirasburg turpentine, the only extract from the pine and fir tribes used in the preparation of the best varnishes. From the larch we have Venice turpentine, used extensively by veterinary surgeons in the treatment of bruises, ulcers, and old wounds; while from the Scotch pine, and pineaster, come tar, pitch, and lamp-black. The introduction of new timber trees of the cone-bearing, or resinous order, during the first half of the present century, has been extensive and very valuable. $\mathrm{Nu}$ merous important varieties of Conifere were introduced by Douglas, a Scotchman, who went to Northwest America as a botanical collector, and brought over, from the banks of the Columbia, the Abies (spruce-fir), Douglasii, A. amabilis; $A$. grandis; $A$. nobilis; Pinus Lambertiana, and other kinds; the 
growth of which in their native country is enormous, and which are now becoming valuable as timbertrees in Great Britain.

Introduction of the Larch into Scotland.-A somewhat singular circumstance in connection with British arboriculture is the fact that, notwithstanding our numerous importations of foreign trees during the eighteenth century, that of the larch to Scotland from Fngland, where it had existed for a century before it got to the sister kingdom, should turn out to be the greatest possible acquisition; and a large proportion of heath lands found in continuous tracts throughout North Britain, that were until lately given up as barren and unprofitable, are now planted with suitable trees, and the timber which is produced on them is more durable and substantial than that grown on richer and more sheltered soils. Early in the eighteenth century a spirit of planting for profit on a large scale began to awaken in Scotland; the Earl of Haddington being one of the foremost to form large plantations, who wrote a treatise upon the subject, it also being recorded that his Countess became so enthusiastic in favour of improvenents by plantation that she sold her jewels to tnable her to plant Binning Wood, which coniprehended 1,000 acres, and was formed in 1705 . The Duke of Argyle, also, at this period, formed very extensive plantations, both in Scotland and England; and the improvements effected are said to have inspired with a taste for planting, the Duke of Athole, the Earl of 
INTRODUCTION OF THE LARCH INTO SCOTLANI). ¿

Panmure, Sir Archibald Grant, Sir James Naysmith, and others, and the example of these extensive landholders caused planting to beconie very general throughout Scotland.

During the first part of the present century the influence of the Highland and Agricultural Society of Scotland has been the means of adding much to the increase of plantations throughout the courtry, in offering various premiums for the introduction of new timber-trees, and the formation of extensive plantations throughout Scotland; while the great success of the larch forests of the Duke of Athole about the middle of the last century, which occasioned that tree to be planted more or less on almost every property in Scotland, las been supplemented by the Earl of Seafield, who has been, perhaps, the most extensive planter of the present century, having planted upwards of thirty millious of plants in a space exceeding 8,000 acres.

There is no soil so barren that may not be rendered profitable by judicious tree-planting; even sand-drift by the sea having been covered with thriving plantations of pineaster trees, where formerly the downs offered to the eye nothing but a monotonous repetition of white sandy hillocks, destitute of vegetation, and continually agitated by the wind; the process having been effected by sowing the seeds of pineaster, and thatching the ground, immediately after sowing, with branches overlapped, to protect the seed ; and protected yet further by lines of hurdles 
to intercept the progress of the sand. In 1840, and the three succeeding years, some of the most thriving sea-side plantations in England were formed on the property of Sir Thomas Fowell Buxton, on the northern extremity of the county of Norfolk. The ground ranges from 200 to 300 feet above the level of the sea, and, generally speaking, the surface is poor and the subsoil a hard, ferruginous gravel. Several examples of this nature show there is no real occasion for the great space of waste land that is often to be met with in maritime situations to be utterly barren ; which, under proper and skilful treatment, could be made profitable by the growth of trees adapted for sea exposure, besides spreading a shelter, and consequent fertility, over adjoining land in bleak districts ; there being certain trees which are appropriate to every soil and situation, which we shall name in detail during the progress of the present work.

The objects of tree-planting are extremely various. As shelter in exposed and windy situations, trees are often very valuable, and are the means of causing the harvest to be ingathered earlier than it would be possible to do without their aid, as well as allowing crops of a certain kind to be grown that it would not be possible to raise without the assistance they afford. As timber-trees, which clothe an otherwise barren hillside, they become valuable property. By the sides of streams and water-courses, they can be nuade the useful and effectual agents for fixing the sides, and confining water to its proper channel, and thus 
1840 , and t thriving rmed on $\mathrm{n}$, on the olk. The the level is poor Several occasion ten to be barren ; could be ipted for id conselistricts ; riate to name in k.

various. rees are sing the be poscrops of possible As tinn. hillside, sides of ade the les, and ad thus

preventing the washing away of banks. In the form of osier-beds, they will yield a profitable return upon districts subject to the overflow of tidal rivers, where nothing else could be grown to advantage; but as living objects of beanty and grandeur, trees everywhere rank with the most beautiful of earth's productions; whetler in the instance of the cedars of Lebanon, which for ages have been the boast of Syria, and a type of Biblical illustration; or in the imposing, lofty forms that are to be met with in the forest, or the parks and pleasure-grounds of Great Britain ; or in some wild sylvan scene in the Highlands of Scotland, in the form of the birch-tree, adorning the margins of lakes and rivers, or standing in solitary glens and ravines in profuse masses; or the mountain-ash, which may be seen in autumn with its terminal shoots bending beneatl their load of clustering scarlet berries, which glisten brightly amongst the varied tints of lovely foliage, peculiar to that season of the year.

By the aid of arboricultural skill, these beautiful specimens of Nature's handiwork can be made to adorn places which are naturally destitute of trees; and this art has fully attested its power in the results obtained at Sion, Claremont, Holkham, Croome, Goodwood, High Clere, Woburn, Studley, Pain's Cross, Chiswick, White Knights, Purser's Cross, and various parks and pleasure-grounds of Great Britain.

Farnesina Gardens at Rome.-One of the most notable instances of this skill is the Farnesina Garden 
at Rome, which formerly used to be one of the great attractions of the city, and which were closed to the public by the Duke Ripalda, upon the announcement to him, by the Government, that it was intended to sequestrate the greater portion of the garden, and destroy the historical casino standing in it, in order to carry out part of the plans for the improvement of the Tiber.

The villa, which Raphael has immortalised, was built for Alexander Chigi, the great banker of Rome of the sixteenth century-the Rothischild of his dayby Baldassare Peruzzi ; and where, to keep the great painter at work, Chigi had to set aside an apartment for the use of the Fornarina. Chigi desired the architect to design the house in proportion to the grounds which extend to the river-side, and make, as it were, the villa and gardens parts of one complete composition. Along the river-side Peruzzi constructed an embankment, and planted upon it a wide ilex and laurel grove, 260 mètres in length ; and at one end also a casino, or summer-house-the same wherein Chigi gave that sumptuous banquet at which Leo X., the Cardinals, the Duke of Ferrara, the Marquis of Mantua, and all the foreign ambassadors in Rome were his guests. At the conclusion of the banquet, all the massive gold and silver plate it was served upon was thrown into the river; but this, it was said, was only an act of shan display on the part of the banker, who had taken the precaution to stretch a net below in the river, of which no trace could be seen, 
e of the re closed the anat it was n of the anding in $s$ for the

ised, iwas of Rome is dayhe great partment ired the $\mathrm{n}$ to the ake, as it lete comistructed ilex and one end wherein Leo X., rquis of Il Rome banquet, $\mathrm{s}$ served vas said, $t$ of the tch a net be seen, but by which means the whole service was restored to the strong-box, with the exception of one unfortunate soup-tureen, that had been unluckily thrown out a little too far beyond it.

The Farnesina contains Raphael's famous frescoes of 'Cupid and Psyclie,' and of the 'Galatea'; the 'Marriage of Alexander and Roxana,' by Sadoma; the splendid frieze of 'Ovid's Metamorphoses,' by Giulio Romano, and the colossal head, a magnificent iiece of chalk-drawing, sketched by Michael Angelo in one of the lunettes, whilst waiting for Daniel di Volterra; and other works of beauty and interest. The names of niany historical characters and renowned beauties are connected with this place during the most brilliant period of the Papacy, who have sauntered along the grove-like ilex avenue, extending from the casino. The trunks of these venerable trees have attained a great size, and from them, at the height of some ten feet from the ground, stretch horizontal branches, the result of exrly training, which form an imposing leafy ceiling. From these again spring innumerable tall, slender, perpendicular branches, through which the brilliant sunshine strikes, flickering along the ground in all shapes of fantastic shadows; while in the bright Italian moonlight, the trees produce an indescribable effect of loveliness.

In the course of years, after its possession by Chigi, the villa passed into the hands of the Farnese family, and from theirs into those of the Royal Family of Naples, who appear to have taken but very little 
interest in it, and left it almost entirely uncared for. It remained for a long time uninhabited, and persons residing in Rome between 1850 and 1870 will renember the ruinous condition in which the house appeared. Several of the ceilings were in such a dilapidated condition that they had to be supported by beams, resting on the floors underneath; and the chefs-d'œuvre of Sadoma, the frescoes which have excited such universal adniration, were scrawled over and defaced by the race of travellers who cannot refrain from scratching their ignoble names upon situations of prominence which give them the opportunity of so doing.

After remaining in this miserable condition for a considerable period, the villa was purchased by the Duke Ripalda, who was Spanish ambassador to France during part of the reign of Napoleon III., who devoted much time and money to it, and reproduced it as a public monument of art, grudging no cost that was necessary for putting the building into complete repair, and, in fact, making its restoration the chief object of his life.

With loving care, and with the assistance of the best artists of the day, he has cleaned the frescoes and repaired the damages they had received in such a complete mamner as to remove every trace of the injuries that had been inflicted upon them by the modern Goths and Vandals from whom they had received danage. In one of the largest rooms it was found that a beautiful frieze, on which the chief 
ared for.

persons will ree house such a pported and the ave exed over not ren situartunity

for a by the France ho deoduced 10 cost o comon the

of the rescoes such of the by the ad reit was chief

subjects of 'Ovid's Metamorphoses ' were represented, the work of Giulio Romano, had been whitewashed over! This whitewash was all carefully removed, and the original painting brought again to light, displaying the sumptuous manner in which it was usual to decorate the houses of the wealthy in Italy in the sixteenth century, and thus restoring from oblivion, if not actual extinction, a beautiful object of art. The fine old coffered ceilings were thoroughly repaired, or, where they were too much decayed, were reconstructed in accordance with the original designs, and the interior of the villa restored in all its former beauty of detail.

Native Trees of Britain and Introduced Trees.There are only about twelve genera and thirty species of the native trees of Britain which attain the size of timber-trees, or trees which range above thirty feet in height ; and only three out of these are evergreens, viz. the Scotch-fir, the holly, and the yew-if even the latter may be looked upon as a native of Britain.

It was during the sixteenth century that plantations began to be extensively formed in England, both for the sake of the timber as well as for embellishment; but long before that epoch many varieties of timber-trees had been introduced intu these islands, of which, as no definite account has been given, it is commonly supposed that we are indebted to the Romans for them, as well as to the monks of the Middle Ages, who were skilful botanists, and to whom 
we owe many of our cultivated fruits and vegetables.

Amongst the earliest introduced trees we have the chestnut, lime, English elm (the mountain, or wych elm, $U$. montana, being a native of Scotland), beech, apple, pear, peach, \&c.

The earliest accounts we possess of the introduction of many of our timber-trees are given by botanists and apothecaries of London, who gathered together all the known specimens they could discover of foreign origin, while forming extensive collections of medicinal plants and trees. About the middle of the sixteenth century at different times was published Turner's ' Herbal,' in which he notices the introduction of the common spruce-fir, the stone-pine, the evergreen cypress, the sweet bay, and the walnut. Towards the end of the sixteenth century Gerard published the first edition of his catalogue, which gives an account of the introduction of the pineaster, the laburnum, and a considerable number of smaller trees and sk: ubs. The evergreen oak (the ilex, the same tree of which we have been speaking as the principal adornment of the Farnesina Garden) and arbor vitce were also introduced in this century.

Gerard had a physic garden in Holborn, and such gardens have done good service in their day to botanical science.

There is one still left in London, though it is but very little known, and it is probable that comparatively few people have ever heard of the Physic 
Garden of the London Apothecaries' Company, which carries with it an odour of simples, and old-fashioned compounds, which the science of modern medicine has left behind in the march of Time. Yet such a quaint old garden is still in being, and is kept up to this day, having been bequeathed by will, at a trifling quit-rent, to the Apothecaries' Company by the celebrated naturalist Sir Hans Sloane.

This garden is close by Chelsea College, and consists of a space of about five acres, surrounded by high walls, and entrance is obtained to the garden through tall iron gates, which are unclosed at the ringing of a bell. A strip nearest the Chelsea embankment, known as the 'kitchen garden,' had originally been redeemed from the bed of the Thames, with the consent of the water bailiff of the period, many years ago. In the centre of the garden stands a statue of Sir Hans Sloane, who bequeathed the land, as aforesaid, upon the condition that it should always be maintained as a garden, and a certain number of plants raised each year, for the purpose of extending the knowledge of medicine.

Dr. Compton, who was Bishop of London from 1675 to 1713 , introduced into England a great number of exotic trees, and did more to advance this branch of knowledge than perhaps any other individual of his time, having imported many of our best trees from that fruitful source of supply-America.

About the middle of the seventeenth century botanical gardens began to be established in varions 
parts of England, which were the means of greatly facilitating the introduction of and acquaintance witl hardy trees. In 1683 the Cedar of Lebanon was planted by Bishop Compton at Fulham, and also in the Chelsea Botanic Garden. The 'Hortus Kewensis ' gives a list of the most important foreign trees that were introduced in the seventeenth century, amongst which are enumerated the larch, horse-chesnut, silverfir, American plane, acacia (locust-tree), scarlet oak, weeping-willow, scarlet maple, Norway maple, balsam poplar, the cork-tree, Balm-of-Gilead fir, the black and white American spruce-firs, \&c.

Parkinson also, a physician of London and apotheeary to James I., recorded, in 1629 , the introduction of the larch, and speaks also of the horsechesnut; but the names of those to whom the introduction of these valuable trees is due are not mentioned.

During the eighteenth century the catalogue of foreign trees introduced into Britain is a very lengthy one, amounting to nearly five hundred; but three quarters of this number were shrubs. Nearly three hundred were natives of North America, the trees consisting mainly of pines, oaks, poplars, unaples, and thorns-varieties of trees which had been formerly introduced. The introduction of new timber-trees from North-west America during the first half of the present century has also been very considerable, particularly, as before mentioned, in the order of Coniferce. Others have been brought to us from the 
f greatly ance with non was $d$ also in 'ewensis ' rees that amongst It, silverlet oak, , balsam le black

nd apoe introhorseom the are not

ggue of lengthy $t$ three $y$ three e trees es, and rmerly r-trees of the erable, der of $m$ the
Himalayan Mountains, such as the Cedrus deodara, Pinus excelsa, and many other hardy and ornamental trees, which may possibly excite the adiniration of future generations; for in relation to the life of a cedar-tree, when placed in a position the best adapted for its growth and development, a generation or two of men bears but a trifling proportion to its durability.

Ancient Forests and their Produce.-In England, previous to the reign of Henry VIII., the timber required in the construction of houses and for general purposes, as well as for fuel, was supplied by the native forests of the kingdom ; and in a previous era William the Conqueror had rendered himself conspicuous in connection with the forests of the kingdom, in his passion for turning them into huntinggrounds, by the vexatious act of restricting the people from fattening their hogs in them, which was one of the grievances that King John had to repeal at Runnemede, where the Barons compelled him to sign Magna Charta.

As swine's-flesh was the principal food of most nations during the early stages of civilisation-which, doubtless, was mainly to be attributed to the extreme rapidity with which pigs multiply_it may easily be imagined that the virtual closing of extensive forests, where these animals obtained the most part of their. food, was felt as a very great hardship. Up to quite a recent period, large droves of hogs were fattened every year upon the mast of the New Forest in 
Hampshire, being collected together every night by the swineherds, who had superintendence of them, by the sound of a horn. In 'Ivanhoe,' Sir Walter Scott gives a description of this occupation in the instance of Gurth, the swineherd of Cedric the Saxon -an occupation the same in its method as is followed equally by modern stock-keepers who have the chance, as well as by our Saxon forefathers.

During the time the Saxons held sway in this country, the fattening of logs upon acorns was considered so important a branch of domestic economy that, about the close of the seventh century, King Ina enacted the panage laws for its regulation; and even so late as the reign of Queen Elizabeth, swine ran wild over the fells of Lancashire and Cumberland, and in the Weàld of Kent. The woods were preserved both for fuel and for the support of hogs, which fed upon the oak and beech-mast, and formed a large portion of the sustenance of all classes. Upon the introduction of hops in this reign (Elizabeth), the Kentish farmers, whose land was overrun with coppice, objected to their growth, by which they are now so largely benefited, ' because they occasioned a spoile of wood for poles.'

As well as swine, wolves used to abound, the race of which in England is commonly supposed to have been destroyed in the reign of Edgar, about the middle of the tenth century; but their existence in that of Stephen has been proved, according to Burton's 'Monast. Ebor.,' under Fors Abbey, by the 
PRESERVATION OF GAME BY NORMAN KINGS. 17 discovery of the record of a grant by Conan, Duke of Brittany, to the monks of the Abbey of Fors, in Wensley Dale, 'of pasturage and grass in the adjoining forest,' but forbidding them to use any mastiffs to drive away the wolves. The importance of the chase as a pastime has been generally supposed to have been most appreciated by the Norman kings, severe laws being enacted for the preservation of game, the pursuit of which not only afforded popular sport, but enabled many delicacies to be obtained for the table; so that rigorous laws were instituted for its preservation, it being more pena! to kill a stag than a man. Although these severe edicts have been attributed to the Norman kings, it has been pointed out by a writer that a code of laws reserving the right of free-warren to the monarch and his nobles is supposed to have been promulgated in the reign of Canute.

By these the freeman forfeited his liberty, and the slave his life, for slaying a 'staggon,' or royal beast, though the murder of the former might be commuted or the payment of two hundred shillings, and of the latter for half that sum. After the Norman Conquest, however, freemen trespassing against the king's venison were punished by mutilation or the loss of sight; and these penalties appear to have been inflicted with no sparing hand under some sovereigns, and existed-with some modifications, pcrhaps, in their execution-until the accession of Edward I., when all the sanguinary part of the code was repealed,
and pecuniary fines inflicted instead. 
It has been assumed that the severity of these laws was not only for the protection and security of the game, but also to exercise a deterrent effect; for, by reason of its great abundance, it was alluring to bodies of idle vagabonds, who, by preying upon it, could live in plenty and freetom; and, from the security afforded by the abundant covert which protected them, from poachers they became robbers, and were nursed up, as it were, into outlaws and ruffians, who preyed upon travellers, and made whole districts dangerous to peaceable inhabitants, although the halo of romance has been thrown over the exploits of such freebooters as Robin Hood and his gang in Sherwood Forest.

Acorns as Food.-The ancient Britons are said to have used acorns as food, and these in much later times have been ground up with peas and beans into flour, of which bread used formerly to be made; while acorns are still used as food by the peasantry of Southern Europe. The oaks with edible acorns are not, however, of the same species as the English oak; and the description which Virgil gives in the second book of lis Georgics, of the tree, the elevation of whose top, the steadfastness of its roots, and the greenness which triumphs over the lapse of age, is the Italian oak, which bore fruit that was used as food. There is another evergreen oak, Quercus ballota, commonly met with in Spain and Barbary, the acorns of which are most abundant and nutritive. Cervantes. in 'Don Quixote,' describes the goatherds 
of these security of effect ; for, elluring to s upon it, from the which prorobbers, tlaws and ade whole although er the exand his

are said luch later eans into ve made; peasantry le acorns e English es in the he elevaoots, and of age, 3 used as is ballota, le acorns e. Ceroatherds
EDIBLE ACORNS.

eating acorns as a dainty, the choicest being picked out for the peculiar delectation of the Countess. But the Quercus ilex-the evergreen oak which is still common in Spain, Italy, Greece, Syria, the south of France, and on the shores of the Mediterraneanbears very different acorns to the bitter fruit of the English oak (Quercus robur), in their agreeable flavour resembling that of nuts.

During the Peninsular War, the soldiers which comprised the French armies subsisted to a considerable extent upon the ballota acorns of the woods of Salamanca, and certain classic authors describe the primitive inhabitants of Greece and Southern Europe as living in easy abundance upon the acorns of the natural forests, upon which they were almost entirely supported. These statements, however, are not so startling as at first sight they appear, if we draw the necessary distinction between the common acorn most familiar to us in England, and that of the ilex, ballota, and esculus oaks. A modern writer has pointed out that the Grecian poets and historians called these people balanophagi (eaters of acorns), which the Romans translated glans (acorn); but this term applied also to such fruits as dates, nuts, beech-mast, and olives. Chesnuts, we may suppose, might also be added; and as all these contain large quantities of oil, which renders them particularly nutritive, the 'fatness' of bodily condition which is described as distinguishing these races, may not be regarded as being so surprising, as if they had subsisted upon 
such very lean fare as the common British oak, or that which a similar tree is only able to furnish. If also we look nearer home, we learn from that extraordinary medley of satire, morality, and manners, 'The Vision of Piers Ploughman '-which is supposed to have been written by a Shropshire priest about the middle of the fourteenth century-that the bread then in common use, to which we huve made reference before, was composed of the flour of peas and beans. The nutritive value of pulse is very great, and the use of it in the form of lentils is, indeed, strongly recommended by certain crotchety people of our own times, witl, it must be confessed, no small degree of reason on their side.

Monastic Grants.-The Doomsday Book, at the Norman Conquest, describes the agricultural aspect of the kingdom as being generally in uninclosed pasturage, or covered with vast tracts of forest and unproductive coppice; and Hallam, in his 'View of the State of Europe during the Middle Ages,'speaks of many of the grants to monasteries, which, although they strike us as being enormous, were in reality districts absolutely wasted, and which could only have been reclaimed by the monks, through whose means there was not wanting a certain amount of encouragement to cultivation, even in the least civilised periods; and the ameliorating principle of human industry struggling against destructive revolutions, barbarous disorder, and the devastation of war, from the fifth to the sleventh century, rendered 
NG.

INFLUENCE OF THE MONASTIC URDERS.

ish oak, or urnish. If

that extramanners, s supposed about the the bread tve made ur of peas e is very lentils is, crotchety confessed,

$\mathrm{k}$, at the ral aspect ininclosed forest and

' View of ss,' speaks although in reality uld only h whose nount of ast civilaciple of ive revotation of rendered land the least costly of all gifts, though it must ever be the most valuable and permanent.

Under the protection afforded by the religious houses, the abbots of which were indulgent landlords, who paid more attention to the moral and material welfare of their dependents, and whose courts of jurisdiction were less arbitrary than those of the great feudal lords, the lands belonging to them were better cultivated than other estates, and more thickly inhabited; while the remains of agricultural buildings, the vestiges of orchards, and other improvements, then but little understood, proved that, even at the era of the Norman Conquest, a considerable amount of care was bestowed upon rural economy by the monastic orders, and the earliest improvements in English husbandry must be ascribed to their skill and industry, though the remembrance of many abuses has caused the monks to be vulgarly regarded as an idle and worthless class, and the good services they rendered in ages of comparative barbarism, to learning, and practical science, are too often over. looked or forgotten. 


\title{
CHAPTER II.
}

\begin{abstract}
FIRST PRINCIPLLS OF PLANTING-SOILS AND SITUATIONS-PALM SONDAY IN ITALY-DURABILTTY OF CEDAR-WOOD-BIBLICAL DESCRIPTION OF THE CEDARS OF LEBANON-THE VISITS OF TRAVRLLERS TO HOUNT LLEANON-OF THE PRINCIPLES OF FERTILITY OF THE SOIL-COBBETT ON TULL-TULL'S PROTEST-THE HUSBANDRY OF VIRGIL'S GEORGICSTULL'S ACCOUNT OF HIS INVENTION OF THE DRILL-COBBETT'S $\triangle$ NTICIPATIONS OF FUTURE CREDTT-COBBETT AND THE LOCUST-TREE.
\end{abstract}

First Principles of Planting.-There is no work, perhaps, in the whole round of rural occupations, in which there is occasion for such diverse practice as that of planting trees. Not only does a very wide difference exist in the nature of soils, but also the degree of exposure ; and in the case of forming extensive plantations, upon the kind of herbage that covers the soil, must depend the size and description of the tree-plants. Where land is covered with furze, plants must be used which will in time extirpate it, while in the case of heath-covered districts, in a dry, sandy, or gravelly moorland, small plants of Scotch pine, spruce, and larch may be planted with great rapidity upon the notch system commonly practised in Scotland, without the soil being pulverised, or prepared in the slightest degree.

The heath, which to the uninitiated would appear likely to rob the earth of the necessary nutriment or aliment needed for the sustenance of the newly 
ING.

-PALM SUNDAY

ESCRIPTION OF

RS TO HOUXT

SOIL-COBBETT

L'S GEORGICS-

OBBETT'S ANTI-

UST-TREE.

no work, pations, in ractice as very wide also the ing extenhat covers on of the ze, plants , while in $y$, sandy, tch pine, t rapidity Scotland, ed in the

d appear iment or le newly

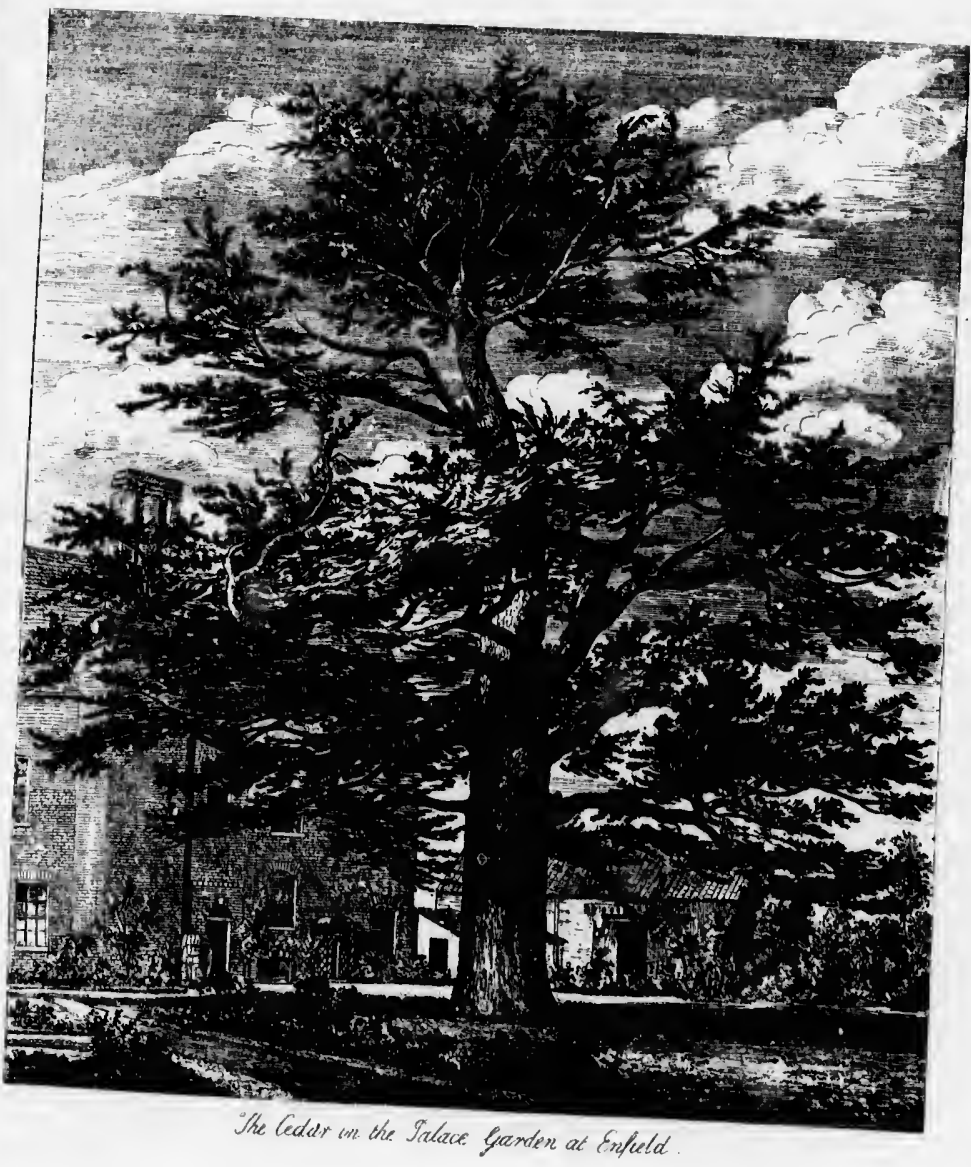




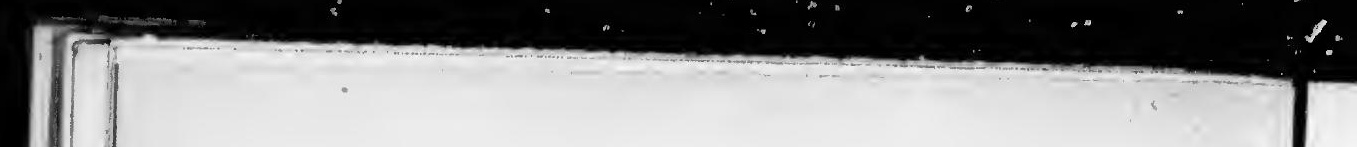


planted tree, when of a moderate size, is, in reality, far more favourable to the growth of the young plants than if they were inserted upon a bare, prepared surface. The cover afforded by the heath gives a large amount of natural protection, while its open stems do not retain moisture to rot the plants, nor do its roots injure them like that of a grassy sward. Young trees of this sort do better, in fact, amongst the heath, than when the soil has been cleared and prepared for their reception; for the pulverised earth, deprived of the protection which the heath afforded, absorbs an excess of moisture that occasions the ground to swell during frost, and subside in open weather; the consequence being that the plants are ejected. This fact is amply demonstrated in the native-grown forests where; associated with the brown heath, they spring up and flourish without any artificial aid ; and nature thus indicates the natural seed-bed of pines.

Deep-rooted trees require a soil more elevated above the rise of water than pines, and other surfacerooting trees. Furze not infrequently forms a dense cover on good soil that is particalarly well adapted for the growth of timber-trees. Such places require the furze to be cut down, and the land trenched, or the furze rocted up, and trees inserted by the method of pit-planting. Larch is the best tree to employ for forming a speedy cover and subduing the furze, although the situation may be designed for a different growth of timber, it can be profitibly used for this 
purpose, and should be interspersed closely, even if they have to be cut down, when. by the confinement they have caused, they have succeeded in extirpating the furze.

In a great extent of ground, its quality is often found to vary considerably, and trees require to be made choice of that are best adapted to each variety. Loose, deep earth will grow any kind of trees. Dry, poor, gravelly, or chalky soils are best adapted for pines, beech, and birch. A deep clayey gravel, or clayey soil, is, generally speaking, best adapted for the oak, which sends its roots deep downwards, and derives its sustenance chiefly from the subsoil. On the other hand, as the larch feeds chiefly on the surface, when an oak plantation is about to be established, it is a safe practice to plant larch trees a few years before, to act as nurses in exposed situations, where shelter is necessary. Where the situation is not exposed, the larch and the oak can be planted together, and as the former grows the fastest, the necessary protection will be afforded in those cases where the services of nurses are needed. After they have performed the purpose intended, the larch can then be cut down.

Beech is more profitably grown by itself than mixed with other trees, as ii is apt to become branchy and broad-headed, and its timber is only valuable when it produces tall, clean trunks; and this is best insured when it is allowed to stand by itself, and not interspersed with other species. Coniferous 
$y$, even if nfinement xtirpating $y$ is often ire to be h variety. es. Dry, apted for oravel, or ipted for ards, and soil. On the surtablished, ew years is, where $n$ is not planted , the nese cases fter they arch can

elf than become is only and this oy itself, niferous trees succeed best on land that is of a light, sandy texture. A deep loam is the most favourable for the growth of the Spanish-chesnut, oak, and ash. In moist bog-land the willow-tribes, the birch, alder, and poplar succeed best; while the order of American plants in most cases make the best roots in peat.

Soils and Situations. - It will thus be seen that both soil and situation require to be considered, both being very important points for consideration in successful tree-planting. With many inexperienced treeplanters this consideration is entirely overlooked, the result being often severe disappointment. An oak planted upon an exposed upland, and surrounded by nurses in a trenched soil, will make rapid progress, and will proceed to assume a satisfactory form in an adequate space of time. But when it attains the age of twenty-five years, there will occur a pause in its growth, its vigour and robustness of habit cease, the bark becomes hide-bound, and the top, unable to withstand the rigour of the climate, becomes scraggyheaded, and its progress is arrested; but if planted in the deep clay soil of the valley, the oak there displays vigour, bulk, and often an appearance of grandeur.

The cedar, though commonly planted in England in sheltered situations, where indeed the quality of its timber becomes deteriorated, and its soft wood is commonly recognised in the form used for lead pencils, stands for centuries in mountain ranges, where its timber becomes hard and durable; as in the instance of the Cedars of Lebanon, which for ages 
have withstood thie fierce storms of the mountains of Syria.

The Scotch pine is popularly represented as a tree that will grow almost anywhere, and so indeed it will, in nearly all situations, for a time; bi. i is very plainly manifests its preference for certai $i_{L}:$ and siuntions. If planted on damp lands it scull ceases to increase in bulk, while if placed in warm southern exposures, the natural consistence which forms its resinous juices becomes deranged, and the oily secretions of its bark, which favour the growth and living economy of the tree, is exuded in the shape of vapour; and the compound of its parts becomes injured and weakened. Its natural habitat is in a sandy loam, with a dry, shattery bottom, in a cool climate, in a northern exposure.

A spruce planted on a northern exposure towards the foot of a hill, where the soil is loamy and damp, will present the most beautiful appearance ; its horizontal branches will touch the ground, and be so close and luxuriant that the stem cannot be seen; and will present a lovely mass of green foliage, which, if left untouched, will remain so for sixty years ; but plant a spruce-tree on a dry, sandy soil, although it will thrive well for six or seven years, when twenty years old, its under branches will be found withered and devoid of foliage, the bark covered with lichen, and the whole tree at a complete standstill.

The soft-wooded trees, which are very quickgrowing, generally affect moist lands, or such as are 
intains of

as a tree d it will, y plainly ad sisuaes tc inhern exits resicretions living hape of becomes is in a a cool

towards damp, ts horiso close nd will if left plant a it will $y$ years ed and en, and quickas are near to water. These, if planted in well-trenched soil that has been prepared before they are inserted, will maintain a fair show for several years, even in sandy uplands, which is the opposite to their natural requirement; but after a time they will give unmistakable signs that they are not in their proper position; and although they may continue to grow, they will do so without vigour or comeliness. Place them, however, in low lands, beside streams or ivers, or wherever the soil has moisture, without being actually saturated by it, and they will put on all the beauty of form they are capable of attaining. These varieties include the willow, alder, poplar, lime, and horsechesnut.

Although some of these are not very picturesque objects for the adornment of scenery-for the alder is not a graceful tree, and the poplar, which in some varieties has an ugly trunk when old-some of them are extremely beautiful, as the horse-chesnut, when clothed in its large, handsome blossoms, and the graceful weeping willow, which can so appropriately be associated with others in localities rendered elegant by art, filling its suitable position by the margin of artificial lakes and pools, and which will beautify even a homely pond ; or perhaps some small patch of water, which, otherwise not so ornamented, would be objectionable near a residence, its delicate sprays, moved by soft breezes, and through which the sunlight flickers. So, situated near a dwelling-house, its hygienic uscfulness is also very great, tempering the 
sun's rays in hot weather, which otherwise would beat upon the unsheltered margins of ponds and stagnant water, and produce miasma, which the foliage of the tree exercises a beneficial influence upon, and mitigates what otherwise would have become objectionable and a nuisance.

The goat-willow (Salix caprea) also thrives well in a moist situation, and is a tree much more worthy of cultivation than the amount of notice it usually receives at the hands of planters leads to. At the latter end of March, when it displays its beautiful yellow catkins, here and there a stray tree or two may be seen growing in a plantation, or belt of trees at a season of the year when the objects of sylvan adornment are really very scarce, and on this account it is well worthy of being planted in the shape of standards in our shrubberies.

On Palm Sundays these catkins do duty for the palm in this country, and sprigs of the goat-willow may frequently be seen borne by the girls of the village in their hands (and in some towns too, for the matter of that, as in Manchester and other northern cities), while the lads wear them stuck in their hats or button-holes. The fashion is a pretty and a touching one, when used as a simple reminder of the sacred event it typifies, and is not allowed to degenerate into mere formalism which is sometimes permitted to take the place of sincere devotional feelings, for there is a poetry about the sacred story which quickens the imagination. 
ould beat

stagnant

ge of the

and miti-

bjection-

Palm Sunday in Italy.-In some Italian cities, upon the last Sunday in Lent an unsparing attack is made upon the palm-trees and olive-trees, which are piled up mountain high on the altar of every church. Here they lie untouched until the benediction has been given, when the youthful part of the congregation rush indiscriminately upon the pile, and a scene of confusion follows that certainly is not in character with the place; but then who could, or would, leave the churcl without a sprig of the blessed palm or olive? The superstitious hang it up by their bedside to scare away evil spirits that otherwise might disturb their slumbers, the lover takes one to present to his mistress, and they are used as peace-offerings to act as mediators between those who have become estranged during the past year, by the petty misunderstandings and quarrels of life, which, alas! not only in Italy, but all over the world, are allowed to separate friends, which upon this occasion it would be churlish to refuse, and a sprig of sacred olive or palm has often been the means of obtaining a renewal of kind words, a smile, or an embrace from friends who have only held aloof from false pride. Palm Sunday is thus commonly welcomed as the period that brings with it a harbinger of love, and ' holding out the olivebranch' has really a literal meaning and significance in these Italian cities. For the palm and olive, the goat-willow, as aforesaid, is substituted in England, and carried about upon the last Sunday in Lent, though its meaning, uses, and poetical associations are 
not realised or appreciated to as full an extent here as by the dwellers in the southern cities of Europe.

Salix caprea, or the goat-willow, grows very rapidly, and soon makes a handsome show in moist situations, which are very often left bare and destitute of trees. The progress of some of the species of poplars and tree-willows on a rich, soft, moist soil, in a period of twenty years, is fully equal to that of many of the best hard-wooded trees in double that time. The Abele and black Italian poplars, with the Huntingdon and Bedford willows, are perhaps the fastest-growing timber-trees of any that are adapted to our climate, when planted in soil that is suited to them.

A very important consideration connected with these trees is that they can be grown upon a description of soil that could not be made use of for any other crop, particularly in the form of sallows or willows, on land that is subject to tidal overflow. Osiergrounds planted with Salix viminalis make a very handsome return in the second year after their formation, the first crop averaging in value fully $30 l$. per acre, and often they have been cut down annually afterwards, yielding a product of between $25 l$. and $30 l$. per acre. Alders are often made serviceable in fixing the banks of water-courses, and preventing the effects arising from the continued washing of the waters, which often carry away large portions of the edges of the banks. Along strips of land by the side of open ditches, by all kinds of streams and pools, 
ent here

urope.

vs very

in moist

destispecies oist soil, that of ble that vith the aps the adapted dited to

d with lescripfor any or wilOsiera very formaOl. per nually $l$. and able in enting of the of the e side pools, by ponds in extensive meadows, often otherwise destitute of shade, willows may be planted with great advantage, as they do little harm to grass, while they are often useful in sheltering cattle from excessive heat in summer-time. Unforiunately, too, they sometimes shelter the flies as well, which are a great plague to cattle, that would often be better off in sheds during intense heat, if farmers could only be persuaded to think so.

The economical and commercial value of the trees and loppings of the willow tribe is also comparatively great, although the value of the wood itself does not rank high. For sheep-hurdles, hoops, poles, wicker-work of all kinds from osiers (willows, as they are technically called), for basket-making, staves for herring-barrels, \&c., the product is useful, while the timber from the larger trees is appropriate for linings of carts, and other purposes where its soft nature renders it desirable for special uses. The consumption of willow-wood for the purpose of making matches is also very considerable; and where trees are wanted for immediate effect, the whole of the sorts mentioned will be found very useful, even if they are cut down when more valued species have had sufficient time to grow up.

Where the soil is thin and poor, in naturally cold and elevated districts, cone-bearing or resinous trees are best adapted for the situation, as the Scotch pine, pineaster (and a few others of a subsidiary order), larch, spruce, silver-fir, and cedar, though the latter 
is not inade use of to the extent it deserves to be, being more regarded in the light of an exotic than as one of the hardiest of trees.

And here it will not be amiss, perhaps, to make some little digression, and enter upon the subject of the apparent depreciation of the cedar as a timbertree in Britain, for which purpose it is often considered worthless, and to which slight allusion has been made before. This opinion has been carried so far that it has caused many to think the timber used in the construction of the temple and palace at Jerusalem, which the voice of antiquity proclaims to have been built of almost imperishable materials, could not have been composed of the wood of the cedar, but of the cypress, or some other hard-wooded tree. But the fact is, the cedar of Lebanon is now cultivated as an ornamental tree, and in England, when they are first raised by the nurseryman, they are changed from pot to pot, with the view of obtaining fibrous roots, until the tap-root is completely lost, and then perhips a free, deep, enriched soil is selected for thein to grow in ; in all probability they are also carefully sheltered from any rough winds by other evergreens being planted arou.d; so that they are kept in an artificially warm condition that is perfectly foreign to their proper nature.

Naturally a very slow-growing tree in soil adapted to the development of its special qualities, everything is done to it to induce rapid growth, and make it shoot up luxuriantly; and under these conditions it 
ves to be, ic than as , to make subject of a timberften conusion has carried so nber used at Jeruis to have ls, could he cedar, ded tree. ultivated they are changed g fibrous and then for them carefully ergreens pt in an oreign to adapted erything make it litions it cannot be a matter of surprise that the texture of its timber is loose, coarse, and spongy. Yet in their native habitat the cedars of Lebanon seem almost incapable of decay. It is said that the timber in the Temple of Apollo at Utica was found undecayed after the lapse of two thousand years; and that a beam in the oratory of Diana at Saguntum, in Spain, was carried from Zante two centuries before the Trojan war; and some of the most celebrated buildings recorded in profane as well as sacred history were constructed from the timber of the cedar.

Even the Scotch pine becomes very deteriorated in quality when removed from its natural situation in a cool exposure to the district of the fertile lowlands : and the timber is much softer, and not nearly so durable, as that produced in a natural Highland forest. The elevation of the cedars of Lebanon is nearly 10,000 feet above the level of the sea, and it was in this keen and biting air, after the lapse of many ages, that the trees perfected themselves, their nourishment being gathered from a subsoil of hard, calcareous stones. The range of mountains from Alexandretta to Jerusalem is in winter covered with snow, which melts after March, except that on Mount Lebanon, which Volney refers to while complaining of the excessive heat from which he suffered when journeying in the valley of the Baalbec. From the continual howling of storms and tempests, which appear to have their birthplace in the mountains of Syria, is derived the Scriptural description of the "violence" 
of Lebanon, undoubtedly a congenial atmosphere for the growth and full development of the cedar.

The cedars of Lebanon must have been very much thinned by the exertions of Solomon's fourscore thousand hewers, for Maundrell, in his journey from Aleppo to Jerusalem in 1696, only reckoned sixteen of the large old trees, though there were many smaller ones standing; and succeeding travellers, who have visited the mountain in later times, speak of the veneration in which these old trees-the patriarchswere held by the Arabs.

Biblical Destription of the Cedars of Lebanon.The sacred historian narrates how "Solomon raised a levy of thirty thousand men out of all Israel ; and he sent them to Lebanon, ten thousand a month, by courses; and he had threescore and ten thousand that bore burthens, and fourscore thousand hewers in the mountains. And he covered the temple with beains and boards of cedar. And he built chambers against it, which rested on the house, with timber of cedar. And the cedar of the house was carved with knops and flowers ; all was cedar, there was no stone seen.'

The prophet Ezekiel, a close observer of nature, describes the majesty and beauty of the cedar, in making reference to 'the waters which made him great,' produced by the streams caused by the melting of the snow on Mount Lebanon at the hottest season of the year; which, doubtless, was the occasion of its reaching a height and magnificence that 
phere for ir.

een very fourscore ney from d sixteen re many lers, who ak of the iarchs-

banon.raised a and he onth, by housand ewers in ple with hambers imber of red with no stone

nature, edar, in de him e melthottest e occace that could not be attained by others differently placed, in situations often parched by a fierce drought, but in this situation made them flourish in a manner that no other tree could approach or equal: "Behold, the Assyrian was a cedar in Lebanon, with fair branches and of a high stature; and his top was among the thick boughs. His boughs were multiplied, and his branches became long. The fir-trees were not like his boughs, nor the chesnut-trees like his branches; nor any tree in the garden of God like unto him in beauty. Thus was he fair in his greatness, in the length of his branches, for his roots were by great waters.'

The Visits of Travellers to Mount Lebanon.-Belon, in recording his visit to Mount Lebanon, says : 'At a considerable height up the mountain, the traveller arrives at the monastery of the Virgin Mary, which is situated in a valley. Thence, proceeding four miles farther up the mountain, he will arrive at the cedars, the Maronites, or the monks, acting as guides. The cedars stand in a valley, and not on the top of the mountain, and they are supposed to amount to twentyeight in number, though it is difficult to count them, they being distant from each other a few paces. These the Archbishop of Damascus has endeavoured to prove to be the same that Solomon planted with his own hands, in the quincunx manner as they now stand. No other tree grows in the valley in which they are situated; and it is generally so covered with snow as to be only accessible in summer.' 
Successive reports of these interesting remains have been furnished by succeeding travellers, all of whom concur in giving similar descriptions, as Rauwolf, in 1570 ; Thévenot, in 1655 ; Maundrell, as before instanced, in 1696 ; Bruyer, in 1702 ; La Roque, in 1722 ; Pocock, in 1745 ; Lamartine, in 1832 ; $\mathrm{M}$. Laura, an officer in the French Marine, and Prince de Joinville, in 1836 ; and Warburton. Lamartine thus describes his visit to these venerable trees :-

- We alighted and sat down under a rock to contemplate them. These trees are the most renowned natural monuments in the universe. Religion, poetry, and history have all equally celebrated them. The Arabs of all sects entertain a traditional veneration for these trees. They attribute to them not only a vegetative power which enables them to live eternally, but also an intelligence which causes them to manifest signs of wisdom and foresight, similar to those of instinct and reason in man. They are said to understand the changes of season; they stir their vast branches as if they were limbs; they spread out or contract their boughs, inclining them towards heaven, or towards earth, according as the snow prepares to fall, or to melt. These trees diminish every succeeding age. Travellers formerly counted thirty or forty; more recently, seventeen; more recently still, only twelve. There are now but seven. These, however, from their size and general appearance, may be fairly presumed to have existed in Biblical times. Around these witnesses of ages long since past, there 
remains

rs, all of

as Rau-

Ill, as be-

a Roque,

832 ; M.

d Prince

amartine

es:-

to con-

enowned

poetry,

n. The

neration

only a

re eter-

them to

ailar to

are said

ir their

ead out

owards

w pre-

1 every

thirty

ecently

These,

e, may

times.

, there

still remains a little grove of yellower cedars, appearing to me to form a group of 400 or 500 trees.'

All the accounts given tally in the probability of the immense age assigned to them. Without doubt, the nature of the tree remains the same, unaltered; and a similar situation to the one so graphically described is the one best adapted for its full development, and not that in which it is most commonly placed by modern practice in this country. Ancient writers bear out the generally received account of the durability of the timber of the cedar, and have noticed that the ships of Sesostris, the Egyptian conqueror, were formed of cedar, one of them being two hundred and eighty cubits long. The gigantic statue of Diana, in the temple of Ephesus, is also said to have consisted of cedar-wood.

All these examples tend to prove that the hardness and durability of the old cedar timber were due to the manner in which it was grown, the exposure it endured, and other favouring circumstances; such as the melting of snows in summer upon mountain ranges, whose fertilising influence would operate upon the roots of the trees; and it thus becomes a question whether the cedar could not, with great advantage, be planted in the northern districts of our own king dom, and flourish in situations that are favourable to the growth of the Scotch pine, upon calcareous formations that are not sandy, and might thus possibly turn out to be the best tree that could be selected for such spots. 
Of the Principles of Fertility of the Soil.-In treeplanting one of the chief principles of fertility of the soil, especially in aiding the growth and progress of young trees, is to have the soil thoroughly and finely broken up. Trees planted in trenched land can be safely calculated upon to make as much progress in six years as they would do in ten, in ground that has not been so prepared. For the practical application of this principle, upon a general and extended scale, we are indebted to the labours of Jethro Tull, the author of the drill, and the horse-hoeing system of husbandry. It has been remarked of Tull that, 'pursued by, rather than pursuing, one ruling idea, his errors and excesses, as they are calied, are as instructive as his most successful experiments. The very failures to which they led, through causes unforeseen, tended to pare down aiid expose in its truer proportions the simple and fundamental principle which he dimly saw, and only missed the full attainment of by the want of a helping hand from that master-science which the genius of Davy and Liebig has since held out to later and more favoured experimentalists.'

The theory of Tull was, that the roots of plants derived their sustenance from minute particles of soil which he terms the pabulum, or food of plants; and by constant pulverisation the superficies of the earth is enlarged, so that fresh pastures are opened, so to speak, for the roots of plants. This pulverisation, he . contended, was quite sufficient without manure, whose only agency was by fermentation to break up the 
-In tree-

$y$ of the gress of d finely can be gress in that has blication d scale, Cull, the stem of t, 'purdea, his instruche very oreseen, proporhich he t of by science ce held ts.'

plants of soil $\mathrm{s}$; and e earth , so to ion, he whose ip the soil : and he grew, for several years successively, crops of wheat upon the same land, without manuring it at all, in ridges with spaces wide enough between the rows for the horse-hoe to pass up and down freely.

Tull has been accused of having been ignorant of the principle of the admission of air and water into pulverised land being one of the chief reasons of the fertility of soil that has been constantly stirred. But this is a mistake, for Tull recommends horse-hoeing, or digging in the driest weather, so as to admit the dews at night, the correctness of which theory any one may find out for himself by digging up a portion of ground in an undigged piece, and after a while looking at the bottom of the piece so turned up, when the bottom will be found moist.

Many farmers of the present day, though they must not be ranked amongst the enlightened ones, say that to plough up land in dry weather will let the drought in, instead of, as Tull contended, letting in moisture from the dews of evening and night.

Tull's labours, and the obloquy he endured, together with his whole life, that was embittered by suffering and disease as well, is mournfully interesting when taken into account with the vast amount of benefit he was the means of conferring upon British husbandry; and his name is almost unknown to the great majority of those who are now benefiting by his experiments.

Cobbett, in speaking of the principles first enun- 
ciated by Tull, in the downright manner which distinguished him, when referring to his re-publication of Tull's writings, says that the memory of the author will at last receive something like justice; for though he does not treat of the detail of planting trees, when one has once read Tull's system he will never plant a tree badly, and will take care that the earth be finely broken, that it lie close to the roots, and that it be not tumbled into the hole made for the reception of its roots in clods.

Cobbett on Tull._-Cobbett acknowledges his obligations to Tull for his theory, and said he had derived both pleasure and advantage from reading his works. Although born and bred amongst affairs of gardening and farming, and reading as well a great deal about them, until he read Tull he knew nothing of principles, and what struck him most forcibly was, when he came so to read him, that all he had read before that had anything like principle in it had been stolen from him, shockingly disfigured indeed, but still, whatever there was of good was his, which contained the whole code of principles of vegetation, applying in all cases, whether in the cornfields, the pastures, the gardens, the coppices, the woods, or the forests.

Cobbett's own words are, in quoting Tull: 'It is curious enough that he was, even in his own time, an object at once of plunder and of calumny. $\mathrm{He}$ says, in the memorandum in which he takes his farewell of the public: "Some have told me that the 
ich dis-

lication author though $s$, when plant a e finely at it be tion of

is oblilerived works. dening about prinwhen read it had adeed, which ation, Is, the is, or time, $\mathrm{He}$ fare$t$ the

whole treatise should have been entitled, Husbandry Mathematically Explained; others Agricultura Tulliana; and this last is the title generally now given it in Ireland. It is said that mine is the first book of agriculture that has happened to be pirated; and that, upon the first notice of it, I ought to have desisted; because I must be a loser by proceeding any further at the press; and that I could have little obligation to a country whose laws did not protect me in the property of my labour (which was the original foundation of property in most things), and of my expense that is joined with it. The best apology I can make for this my folly is, that it is natural for the true parent rather to lose the property of his offspring, than not endeavour to preserve the life and wellbeing of it, though in the hands of enemies."

"Would this apt and beautiful allusion to the story of the true and false mothers, who brought their dispute before Solomon, have any effect on the pirates to whose baseness Mr. Tull here alludes? Not it, indeed; except to induce them to add abuse of the author to the stealing of his property.'

Tull was brought up to the profession of the law, but having an estate which he was unable to let to advantage, he took it in his own hands, and published an account of the experiments he made. In his 'Notes on the Preface,' he speaks of a society of writers, who were anonymous, and whom, therefore, as well as on account of the doctrine of equivocal generation of plants, which they held, he calls ' the 
Equivocal Society,' and sometimes, for the sake of brevity, 'Equivocus.'

This society, as mentioned by Cobbett, published a periodical work on agriculture; and it also appears that they contended against the drctrines of Tull, and treated him with great severity and brutality; and freely alluded to his private affairs, which Tull resents in pretty strong language, for he seems to have been capable of inflicting as hard blows, at times, as even Cobbett himself.

Tull's Protest.-It is melancholy to read of the tria!s of temper to which he was exposed by constant misrepresentation, of which the following will give some idea :-

'Before I conclude my notes on this chapter of the comparison between the two sorts of husbandry, I will give an answer to a very false and malicious assertion of the Equivocal Society, though having already proved their notorious and wilful want of veracity in their pretended description of my farm, and in many other particulars, I need take no notice of any more of their untruths, with which their work so plentifully abounds, but this one on which they lay the greatest stress. It is in p. 37 of their Essay for July, in these words, viz., "The proprietor himself, instead of raising one estate by this and other new invented pieces of husbandry, has well-nigh spent two!"

"These latent authors must be very much conceited of their own penetration, if they pretend to know my 
affairs better than I do; and if I know them, I have been so far from spending an estate in any manner, that my circumstances are now better than when I first set out in the world, notwithstanding masiy uncommon and inevitable misfortunes of divers kinds that have befallen me; amongst which, the loss of health, obliging me to quit the profession to which I was bred, and to travel for saving my life, may be reckoned.

' As to agriculture, it was not by choice, but a sort of necessity, that I practised it; and I never kept an acre in my hands that I could reasonably dispose of to a tenant; I knew too much of the inconvenience and slavery attending the enormous power of husbandry-servants and labourers over their masters (those were not the days of strikes and unions, either) to propose to myself any other gain by occupying of land, but to repair the injuries done it by bad tenants, and to keep it till I could let it at a reasonable rent to such as I thought good ones.

'I have occupied only two farms; the first was in Oxfordshire. I so much improved that farm in nine years as to let it for above a third more rent than it was ever let for before; and that being almost thirty years ago, the rent is not sunk yet, but likely always to continue or increase. But the lands of the farm I have now lie so remote from all farmers, that they cannot be let without the house where I live, and which is situate in an air that I would not willingly part withl. 
' To avoid this, and yet be out of trouble, as I was likely to be confined to my bed, I prepared materials for building a new farmhouse; and had in a manner agreed with a tenant to enter on my farm the last summer ; which was disappointed by an accident, and now, perhaps, I may be forced to keep it as long as I live. However that may happen, I am confident (all things considered), that in the time $I$ have already occupied it, if I had managed it in the common course of husbandry, the value of its purchase would have been lost by it; though a robust, able-bodied farmer in the clovering and turnip method might have thrived upon it; but every Virgilian farmer that has rented it (there have been few oihers, since it was first made into a farm), that being about seventy years ago, has either broke, or quitted it before the end of his term.

'It is to the new husbandry' (his horse-hoeing system) that I owe the property of my farm; and all that I here have said, I can make appear to any gentleman whose curiosity shall induce him to inquire of me to find the truth for his satisfaction. My estate is not so large as to leave an overplus for acquiring another, after the expenses of maintaining me in the manner I have been accustomed to live. I propose no more than to keep out of debt, and leave my estate behind me better than I found it; which, unless some new accident prevent, I shall perform : whilst not only naany farmers in my neighbourhood have broke, and several gentlemen-farmers have lost their 
estates larger than mine, and others more money than all I have is worth, by the old husbandry, and by the many chargeable superinductions, their horses, bailiffs, \&c., incident thereto, within the time I have been practising my scherse; though generally the first inventor of a project is a loser. But my scheme diminishes the usual expense so much, that one who understands it can scarce be in danger of losing by it ; yet, owned it must be, that had I, when I first began to make trials, known as much of it as I do now, or as the diligent reader of my Essay and this Appendix may, the practice of it would have been more profitable to me.

' But suppose I had wasted my substance, are there not many who by family misfortunes or otherwise have lessened their estates, though they have never practised agriculture? Nor do I think any gentleman ought to repine at the smallness of his estate, if (without his own fault) it be reduced to his bare share of the island; which will be in justice the less in proportion as that possessed by his ancestors has been greater and longer enjoyed.'

The Husbandry of Virgil's Georgics.-In the foregoing reference made by Tull to Virgilian husbandry, he contrasts his own method of deeply stirring the land, which he calls the new system, with theirs, which was to plough only once, or perhaps twice, and follow up the system of paring and burning. And thus Tull got into hot water with the critics of his day, for speaking of the bad husbandry that is so 
finely expressed in Virgil's first Georgic; and, as is very often the case under such circumstances, he was blamed for censuring Virgil as a poet, which is what he did not do, and he defended himself by saying: ' I do not say it is a great fault in Virgil to be wrong either as a poet or a husbandman; I only think I prove that he is wrong in the latter capacity; and I have not so much veneration for the prince of poets as to think that right which my reason and experience convince me is wrong; and I cannot help thiuking the late commentator much in the right, when, blaming Mr. Dryden's version, he says, that if you take from Virgil his figures, you take the club from Hercules; neither can I dissent from Seneca in my opinion of the Georgics, because he, living nearer to Virgil's time, could better judge of them than Equivocus. Take Seneca's words in his 86th Epistle, Englished by Mr. Cowley in the notes on his "Davidies," as follows, viz., "Virgil did not look upon what might be spoken most truly, but what most gracefully; and aimed more at delighting his readers than at instructing husbandmen."

"Equivocus demands the reason why I find fault with one of the best authors of antiquity, whose husbaiiury has stood the test of so many ages? To which he gives himself an answer as ridiculous as false. And then he goes on to say of me as follows, viz., "He might, indeed, have attacked a Bradley, or even a Woodward (as he has done), with very good success, but a Virgil is certainly an 
over-match for him ; and it is much to be wondered at that Virgil's translator, who has so just value for him, should let this great adept pass so long unobserved."

'It is well known that Virgil was bred a farrier, which we call a horse-doctor, which trade has generally, in most countries, annexed to it that of a blacksmith; it doth not indeed appear that he had both those tracles; but, however, his farrier's trade was sufficient to take up his time in learning and practising it, until he went to Rome, and then he had something else to do than to plough: therefore the only time he was likely to have for ploughing must be before he was arrived at years proper for learning his trade, and most of that time, too, seems to have been spent in keeping goats or sheep, as many of the boys of our lower class of people do. However such an age, wherein even plough-boys that do nothing else but plough, are very incapable of making useful observations upon arable industry; so that Virgil could have little or no experience in it of his own, and must have taken what he wrote from books written by those authors who have lived when agriculture was in its most imperfect state, as Hesiod and the other Greeks did.

' Virgil was born a poet, and undoubtedly the best (of the Latins) that ever wrote; but neither he, nor any other, I believe, was ever born a farmer. Talents in husbandry must be acquired by long experience and diligent observations therein; and he that will 
make any improvements therein must sometimes deviate from the old beaten road of Patrios cultusque habitusque locorum, by way of trial.

' Poetry, like music, is a very pleasant and innocent amusement of life; but we ought not to suffer our diversion to captivate our reason; and if we seriously consider the scope and design of the "Eneid" and "Georgic," what opinion can we have of Virgil's regard for truth? Or if it be true, as Ruæus relates, that Virgil's advice and persuasions entailed perpetual slavery upon the bravest people in the world, we cannot but know what a patriot he was, and how his principles ought to be esteemed by all the lovers of liberty. And I do not think it more injurious to Virgil's memory to say that he was the best poet and the worst field-husbandman, than it is to Tully's to say that he was the best orator and the worst poet.

' Should any author in prose have given a caution to the Italian farmers against planting their lands with perfumes, ivory, frankincense, castor, or steel, would he not be thought very impertinent?'

In reference to the lines-

Multum adeo, rastris glebas qui frengit inortes,

Vimineasque trahit crates, juvat arva

rendered

Much too he he!ps the field, who every clod

With harrows breaks, and drags the hurdle' 'nad,

Tull remarks: 'Equivocus accuses ine for disliking harrowing and hurdling generaliy, when I only blame 
metimes ultusque

nnocent

fer our eriously $d$ " and yil's rerelates, rpetual ld, we Low his vers of ous to st poet

Tully's t poet. aution lands steel,

liking blame

the method used by our worst Virgilians of scratching the superficies of the land instead of tilling the staple of it, which, if it were well tilled, there would be no clods to occasion the trouble and (if the land be moist) the damage of harrowing. But, I believe, nobody ever denied, as he would insinuate, that harrowing or hurdling is necessary for covering of sown corn, or grass seeds, except such corn as is sown under furrow.

' This way of tilling the land with harrows, recommended by the poet, seems to show his husbandry was degenerated from that of the old Romans, who said, Male subactum agrum qui occandus sit. (Col.) (That field is ill tilled that wants harrowing.)

' A yet worse contrivance it was to till with a hurdle made of vine twigs. This is so puerile an invention, that he might have directed it to be drawn by a hobby-horse.'

Time has, however, vindicated sufficiently the correctness of Tull's principle as to the necessity for an abundant pulverisation of the soil; and he gives the following interesting account of his invention of the drill, which some of his critics asserted he had obtained the idea of, either in France or taly.

Tull's Account of his Invention of the Drill.-.' I should not trouble the reader with an account how accidentally the drill was discovered were it not to show that the knowledge of a thing which seems despicable, or impertinent, may unexpectedly become useful at one time or another. 
' When I was young, my diversion was music ; I had also the curiosity to acquaint myself thoroughly with the fabric of every part of my organ; but as little thinking that ever I should take from thence the first rudiments of a drill, as that I should ever have occasion of such a machine or practise agriculture; for it was accident, not choice, that made me a farmer, or rather many accidents, which could not then possibly be foreseen.

'It was my chance afterwards to have a large farm in hand, which I could not well dispose of ; and it being about the time when plough servants first began to exalt their dominion over their masters, so that a gentleman farmer was allowed to make but little profit of his arable lands ; and almost all mine being of that sort, I resolved to plant my whole farm with St. Foin; but the seed of it being scarce and dear, and very little of it good, I found it would be very difficult to procure sufficient quantity to sow, at seven bushels to each acre, which were usually sown. Whereupon I began to examine whether so great a quantity of seed was absolutely necessary, and whether the greatest part of the seed sown did not constantly miscarry, either by its badness, or from being buried too deep, or else lying on the ground uncovered; and I observed in several fields of St. Foin, sown with that proportion of the seed, that in those parts of them which produced the best crop there were (as I counted them when the crop was taken off) but about one plant for each square foot of sur- 
usic ; I

roughly

but as

thence

ld ever

e agri-

made

could

large

$f$; and

ts first

ers, so

ke but

mine

farm

and

uld be

ow, at

sown.

reat a

lether

tantly

being

un-

Foin,

those

there

aken

sur-

TULL'S ACCOUNT OF HIS INVENTION OF THE DRILL. 51

face; and yet the number of seeds in seven bushels sown on each acre, being calculated, amounted to one hundred and forty to each square foot; and what was yet more observable, in other parts of the same fields, where a much less number of seeds had miscarried, the crop was less.

'Then after I had learned perfectly to distinguish good seeds from bad, and had, by many trials, found that scarce any, even of the best, could succeed unless covered at a certain exact depth (especially in my strong land), and had also found the reason of this nicety, I employed people to make channels, and sow a very small proportion therein, and cover it over exactly.

" This way succeeded to my desire, and was in seed and labour but a fourth part of the expense of the common way; and yet the ground of seed was better planted.

' Ten acres being so well done, I did not doubt but a thousand might have been done as well in the same manner; but the next year, as soon as I began to plant, I discovered that these people had conspired to disappoint me for the future, and never to plant a row tolerably well again; perhaps jealous that if a great quantity of land should be taken from the plough, it might prove a diminution of their power. I was forced to dismiss my labourers, resolving to quit my scheme, unless I could contrive an engine to plant St. Foin more faithfully than sucl hands would do. 
' To that purpose I examined and compared all the mechanical ideas that ever had entered my imagination, and at last pitched upon a groove, tongue, and spring in the soundboard of the organ. With these a little altered, and some parts of two other instruments, as foreign to the field as the organ is, added to them, I composed my machine. It was named a drill, because when farmers used to sow their beans and peas into channels or furrows by hand, they called that action drilling.

'It planted that farm much better than hands could have done, and many hundred acres besides ; and thirty years' experienc 3 shows that St. Foin, thus planted, brings better crops and lasts longer than sown St. Foin.

'This drill has also been used almost as long in planting mosi kinds of corn for hand-hoeing, and these last nine years for horse-hoeing.

' I was surprised to hear that some gentlemen pretend I brought the instrument from France or Italy, when it is well known it had planted two farms with St. Foin before I travelled, which was not till April 1711, being above ten years after making and using iny drill. The praised commentator of the "Georgic" can testify this, he having twenty-seven years ago seen the fields of my last farm planted in rows by it. I gave one to a neighbour, who used it in his fields every year whilst I was abroad, and it would be strange if I should bring it from countries where it never was. 
HORSE-HOEING DERIVED FROM FRENCH VINEYARDS. 53

ared all y imaongue, With other gan is, It was to sow ws by

hands sides ; , thus than

ong in , and

lemen ce or farms ot till $g$ and $f$ the seven ed in ed it nd it tries

' $I$. could bring a multitude of undeniable testi. monies to prove myself the sole inventor; but as I am no patentee, nor can have any benefit, but rather less by publishing the invention, I should not care who took it upon himself, were I not apprehensive that some ignorant impostor, pretending himself the inventor, might by that means impose upon the world in vending a false, useless engine for a true one; his conceited workmen will be still improving one part or other of it, till it will perform nothing, after having performed well for almost forty years. And then the invention being lost, who will have recourse to my cuts for restoring it, if I am not known to be the inventor?

' But I own I took the first hints of my horse-hoeing culture from the ploughed vineyards near Frontignan and Sett in Languedoc; and after my return tn England, having land come to my hands, I improved those hints, by observing that the same sort of vineyard tillage bestowed on potatoes and turnips, had the same effect on them as it had on these vines, and my practice ever since has been a further confirmation to me of the truth of the same principles.'

Cobbett, in speaking of the common practice which prevails very often of drenching the roots of newly planted trees with pailfuls of water, remarks : 'Mr. Tull does not treat of transplanting field plants at all; and he (who wrote when Swedish turnips had not yet been heard of in England) says, that transplanting is not so good a way as sowing in rows and 
horse-hoeing. But it was from reading Tull that I carne to take, by preference, dry weather to transplant in, and not the slowery weather chosen for that work by all the writers, French as well as English. Tull had taught me that it was finely broken earth that I ought to have about the roots of my transplanted plants. This I could not have if I transplanted in the wet. The instructions, on this head, given in my "Year's Residence," a seedsman in London tolu me, contained the most valuable discovery that he had met with in any book. It certainly is valuable; but though I had had instances of the effect, I never knew the cause, and never should have attempted the thing on an extensive scale, had I not read Tull.'

The way that Cobbett took up the cudgels on behalf of Tull, and laid about him right and left, is highly diverting and characteristic. Referring to Tull's assailants, he says: 'They were in their day, in agriculture, what the greater part of our reviewers now are in politics. They had no names any more than our critical sages have; and, if it is not improbable that some future editor of "Cobbett's Essays on Paper-Money" may have to perform for the "Edinburgh and Quarterly" conjurors the office which I am now performing for Tull's "Equivocal Society," who and whose works are now what "Walter" and "Stoddart" and "Old Times" and "New Times" will be fifty or sixty years hence; that is to say, wholly unremembered except in the 
pages of those works, which they have vainly endeavoured to suppress by their calumnies on the authors.'

Cobbett's Anticipations of Future Credit.-Cobbett, as will have been seen, rather expected that posterity would give him credit for the work he was doing in thus manfully defending the memory of Tull's inost valuable inventions, and he certainly deserves it; but these anticipations were also extended to other matters, for between the years 1820 and 1825 he imported large quantities from America of the seeds of the Robina pseud-acacia, a leguminous tree belonging to Diadelphia Decandria in the Linnæan system, which he sold under the name of Locust-tree, the popular name for it in its native districts of America, and he was the means of giving a great impetus to its cultivation; many believing it to be a newly introduced tree, for he extolled it in his 'Woodlands,' and other publications, as being far superior to any other, both for rapidity of growth and durability of timber.

The tree had, however, long been known in Europe, for, according to Loudon, the first plant of the species that was brought to Europe was planted in the Jardin des Plantes, Paris, in 1635, and two hundred years after, in 1835 , it was still there, having attained a height of seventy-eight feet.

Cobbett and the Locust-tree.-His statements, indeed, created a sensation throughout the country for the time being, which caused the tree to be planted 
to an unprecedented extent, but it has lapsed back again into semi-obscurity notwithstanding the high praises he lavished upon it.

He describes the timber as being absolutely 'indestructible by the power of earth, air, and water ; and that the time will come, and it will not be very distant, when the locust-tree will be more common in England than the oak; when a man would be thought mad if he used anything but locust in the making of sills, posts, gates, joists, feet for rickstands, stocks and axletrees for wheels, hop-poles, pails, and for anything where there is liability to rot. This time will not be distant, seeing that the locust grows so fast. The next race of children but onethat is to say, those who will be born sixty years hence-will think the locust-trees have always been the most numerous trees in England; and some curious writer of a century or two hence will tell his readers that, wonderful as it may seem, the locust was hardly known in England until about the year 1823, when the nation was introduced to a knowledge of it by William Cobbett.'

We shall speak of the tree at length under its proper classification, but we may remark here that, in favourable situations, it produces small timber, suitable for props to shrubs, stakes, \&c., and for this purpose is better adapted, perhaps, than the wood of any other tree; but its value as a timber-tree, it must be confessed, in the foregoing description, has been greatly exaggerated. 
Enough, however, has been said to show the great advantage that accrues to the roots of trees, or to any other plant, by being surrounded with fine, wellpulverised earth; and the drill system invented by Tull_which, by admitting the passage of the horsehoe between the rows of plants, allows the earth to be divided into smaller particles, and so opens the soil to the admission of air, the rain, and dewsillustrates upon a large and general scale these advantages, in which the roots of trees also participate to an equal extent, by the same course of management.

Under certain conditions, as we have before pointed out at the commencement of this chapter, Scotch pine, spruce, and larch plants may be planted by the notch system in heath-covered districts without any preparation of the land whatever, such as dry, gravelly, or sandy moorland, in which case the roots of the young plants gradually establish themselves firmly in a soil that is a natural one for them, and which no amount of preparation could excel; but in pit-planting especially, and in all cases where large trees are expected to grow in a close and retentive soil, their growth will be considerably hastened on by the soil being deeply stirred, and the earth well pulverised. 


\section{CHAPTER III}

THE MODERN RAGE FOR PLANTING-TREF-PLANTING DISTRICTEARING OR RESINOUS TREES FTT FOR COLD AND GLEVATED LAND-BROAD-LEATED TING AND SOFT-WOODED TREES FIT FOR MOIST CORATION AND GOOD TOIL9BR-TREES SUITABLE FOR LANDSCAPE DRDECORATION.

The Modern Rage for Planting.-The subject of tree-planting has very much engaged the attention of vestries and municipal authorities in our country towns lately, but unfortunately planting is often done without judgment, and the result ends in disappointment in a good many instances. This is a great pity, for municipal buildings and thoroughfares could be often much improved, and their stately appearance considerably heightened, by the judicious planting of trees suited to the soils and situations these buildings or districts occupy. Many trees that have been selected for the adornment of country towns have been wrongly chosen, and the result has been that, instead of being surrounded by objects of natural beauty, which trees in full leaf undoubtedly areespecially in hot weatler, when the eye rests upon a mass of green foliage, amidst which the brick or stone edifices make a suitable contrast-a few miserable, stunted shrubs bear witness to the mistake 
that has been made in their selection, in not plant. ing the appropriate kind that is suitable for the position.

In Manchester, the Infirmary stands in the middle of the city-a conspicuous object-round which there are seats placed, upon which may be seen sitting, in their dinner-hour, a great many of the factory hands, who rest from their toil during a brief interval, the surrounding space being entirely destitute of the ornamentation and shade which trees would afford; at the time the lines are written, only a few sickly stunted shrubs at the back, attesting the want of judgment that has been used in the attempt at arboretical decoration; while in the Cathedral inclosure a few bare poles, or ghusts of trees, stand in a melancholy row, according with nothing, except, perhaps, in a typical sense, any one straining for an illustration could fin' it in the flat tombstones, recording the decease of individuals, that are spread upon the ground; offering a picture of melaucho ${ }^{7} y$ desolation that is very depressing to the visi or who, coming from some southern county, looks upon these futile efforts, when it is well known that trees and shrubs call br chosen which will stand the smoke of cities as well as the bleak air of a northern climate.

Tree-planting at the Antipodes.-Not only in many parts of the Old World is tree-planting exciting a good deal of attention, but also in the New World as well the subject has cone in for its proper share 
of notice, many of the new cities at the antipodes being now laid out with freshly planted trees.

Under the date of August 8, 1879, the correspondent of the Globe newspaper writes from Melbourne an account of what is being done in Victoria, where he describes the winters as being exquisite, and makes reference to certain trees that have been planted, some doing well and others not, while allusion is made to other matters which possess a great interest to those who delight in rural occupations, and who are fond of making experiments.

The writer says: 'In Victoria the winters are simply exquisite. Frequently we have days together of cloudless sky, frosty nights, and a fresh wind blowing all day. The camellias, growing in the open air, are a wonder and a charm to behold. I am glad to say that the authorities have been planting our streets with trees, and most of our great thoroughfares will before long be turned into boulevards. Unfortunately, too many trees of the genus pine have been planted in our open spaces, for it seems too certain that they do not last more than thirty years. Oaks and elms flourish exceptionally well in this climate, and the elm avenue in the Fitzroy Gardens is a real wonder.' What follows is also extremely interesting upon a different subject-the acclimatisation of hales and rabbits in Victoria :-

' It may interest some of our sporting friends in England to know that the hares have increased so much in all parts of this colony that they are be- 
coming a regular nuisance. They bark the young English trees, devour vegetables, and make themselves generally disagreeable. Regular battues have been held in the western district, where three or four hundred pussies have been shot in a day. They are sold now in Melbourne at about 2s. a head, at Camperdown at $4 d$. each. Rabbits are not only a drug in the market, but are actually eating out poor farmers to such an extent that it has been considered necessary to pass all act for their suppression. They ar killed by putting suffocating gas into their holes, and then stopping them up. Some sporting squatter thought it would be good fun to introduce foxes for the sake of sport into his district, and the result has been that poultry has got very scarce in his neighbourhood. This is in the vicinity of Geelong. It will not be long before la chasse au renard is popular here in the French fashion, for animals have a trick of breeding more often out here than at home, and producing more at a litter,' \&c., \&c.

Pari passu, it may be remarked here how truly this result may be said to have taken place with regard to sheep, and the consequent large trade that is now done in Australian wool, of which very considerable quantities are now annually sold at the series of wool sales held at the Wool Exchange in Coleman Street, London, which attracts not only English buyers, but Continental ones as well, especially the representatives of French and German houses, who keenly compete with the manufacturers 
of this country for the possession of the best lots of wool, those of super-excellent quality commanding very often what are termed 'fancy prices.'

Our business is, however, with English trees and English tree-planting, and of these we shall speak in detail, first premising that, for the sake of convenience, trees may be grouped under four principal headings or divisions, according to their nature and the object of the planter, whether it be simply for ornamentation or for profit, and the means he has available for their cultivation, which must in all cases mainly depend upon soil and situation.

Cone-bearing or Resinous Trees.-First in order, perhaps, come the cone-bearing or resinous trees, adapted for cold and elevated districts, where the soil is thin, poor, or sandy. The great importance of these is readily seen when it is considered that by their means vast tracts of hilly or mountainous land, incapable of producing anything beyond a scanty herbage of a poor description, fit only for the sustenance of a few mountain sheep, may be converted into profitable fir plantations and pine forests, which, under efficient management, niay be made to yield a profit that will equal that obtained from arable land, the expense of planting being comparatively trifling when done upon the method known as the notch system, many hundreds of acres, which are now standing, of thriving Scotch pine plantations having been established at an expense of $12 s$. per acre.

The British cone-bearing trees mainly consist of 
ots of

nding

and

ak in

onve-

cipal

and

$y$ for

e has

all

rder, rees,

the

ance

t by

and,

anty

ten-

rted

ich,

d a

and,

ling

otch

ind-

een

of

the Scotch pine, pineaster, larch, spruce, silver-fir, cedar, and a few others of minor importance, for, although the cedar is not made use of to the extent it might be, the tree itself is capable of being planted in the same way as Scotch firs, instead of being treated as an exotic, which is more commonly its fate, the unnatural positions assigned to it being the cause of its great deterioration so far as the timber is concerned, which, when naturally green, is hard and durable, but becomes soft and perishable when the tree is raised upon low-lying rich soils that are quite unfitted for it, being an exceedingly hardy tree, thriving on soils of various descriptions, but requiring an open subsoil, sufficiently high to be above the rise of water, yet near enough to a stream or flow of water for its roots to feel its beneficial influence, such as the melting of the snows upon its most celebrated habitat-Mount Lebanon.

The value of the cone-bearing order of trees, beyond the timber they produce, is enhanced by the fact that nearly all of them, excepting the larch, are evergreen; and thus afford warmth and shelter in elevated districts-not only in their capacity of nurses during the infancy of broad-leaved trees, which without such aic could not be made to grow, but give shelter enough for the husbandman to raise crops of various farm produce which, without this shelter they are enabled to furnish, could never be raised.

Fast-growing and soft-wooded Trees, fit for moist land. - The second division of strongly marked trees 
as regards their habit may be classified as fast-growing or soft-wooded trees that do well in moist land, or near to water.

Among this division are to be found trees that speedily make a handsome show in bare situations, where they will do well for a time, even if the soil is not damp, if it is well trenched previously to planting; and it is to this class of trees that the planter must look who may perhaps heve built a house in a bare situation, and sighs for the adornment that wellestablished trees can give, but who cannot wait for the growth of 'ancestral oaks,' but must needs perforce have recourse to the friendly aid of the poplar to give him that umbrageous shade and soft murmuring of leaves without which his fine country house, built upon the most approved modern principles, is quite incomplete; for the Londoner, and the succesful tradesman or manufacturer is no longer satisfied to pitch his dwelling close to the roadside, and, according to Cowper,

And call it country air;

but wants the adornment that trees alone can furnish ; and these he can obtain in the soft-wooded and fastgrowing trees, which can be cut down after they have performed the purpose for which they were intended, may be, and give an aspect of completion and finish to a new building, while slower-growing and more valuable trees are coming to maturity. 
ast-grow-

land, or

rees that

tuations,

ne soil is

lanting ;

ter must

a a bare

at well-

wait for

eds per-

e poplar nurmur-

y house, ciples, is successatisfied te, and,

furnish ; nd fast-

er they $y$ were npletion growing ty. . 


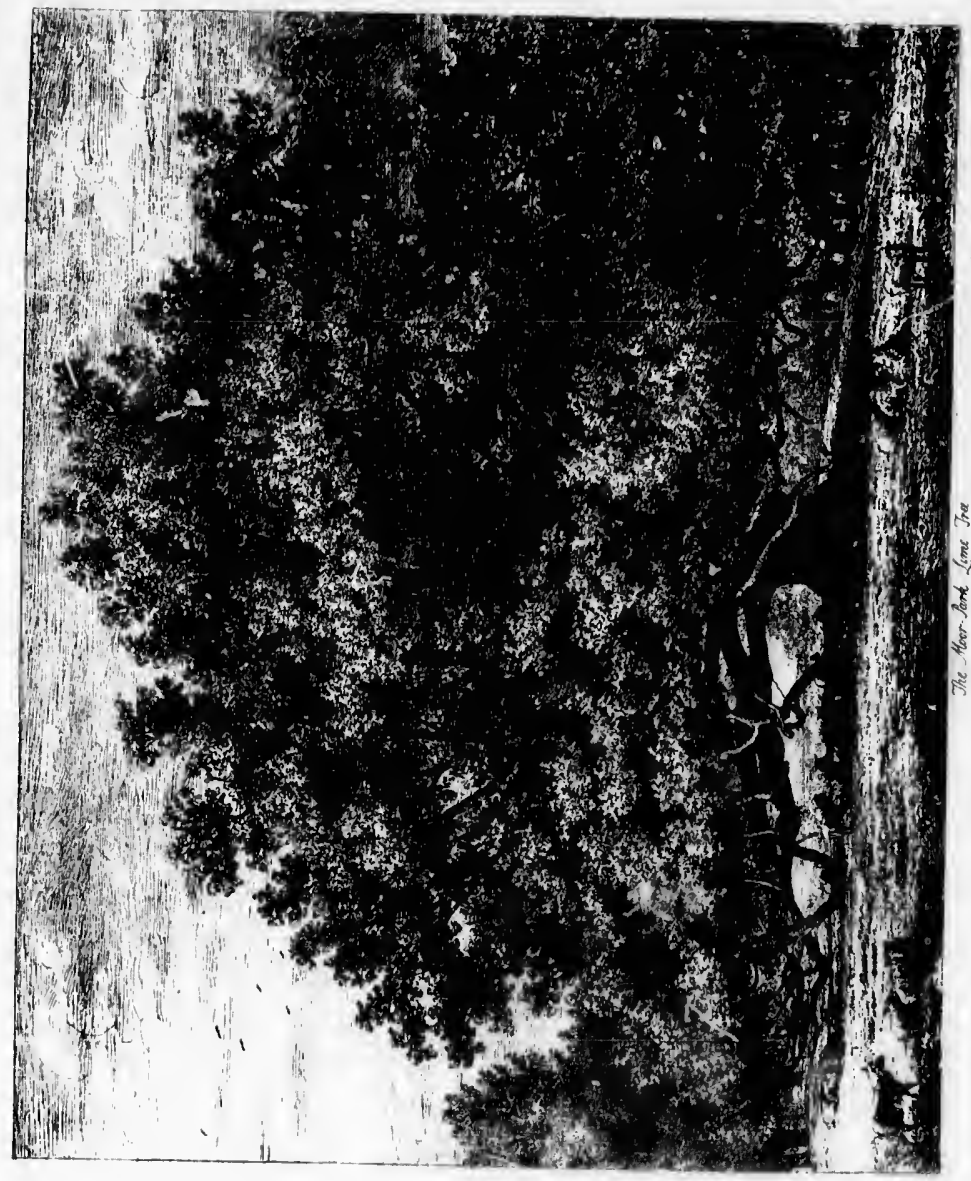


These trees, in addition to the poplar, are the various tribes of willow, the alder-an especially useful tree in low-lying lands by the borders of streams-the lime, and the horse-chesnut. The fibrous nature of the roots of the latter tree, if it has been frequently transplanted, will enable it to be removed with safety at a greater size than that at which most trees are ordinarily removed; and on this accous. it is a valuable tree for producing an immediate efiect in forming lines, or avenues of approach to a house or mansion, and in converting a plain field, or stretch of meadow land, into an incipient park, where their presence will entirely alter the aspect of a flat, uninteresting district, destitute of ornamental trees.

The writer upon one occasion visited the house of a well-known banker in a northern county, that is celebrated more for its manufacturing skill than the attention bestownd upon arboricultural effect, and his expectations had been raised by the description given of the old house by a friend to whom he had announced this intended visit, and his expectations were raised to the utmost by a description of the old hall covered with ivy, surrounded by trees in which the rooks built their nests, reminding one of pleasant Washington Irving, who draws the distinction between rooks and crows-a distinction that a good many Englishmen seem to Lf incapable of arriving at, who are not acquaintea with the birds that are indigenous to our country, and who call crows rooks, and rooks crows, indifferently; but which Washington Irving 
so agreeably describes, and draws a clear distinction between, when he says: "The rooks are old-established housekeepers, high-minded gentlefolk, that have had their hereditary abodes time out of mind; but as to the poor crows, they are a kind of vagabond, predatory gipsy race, roving about the country without any settled home. "Their hands are against everybody, and everybody's against them," and they are gibbeted in every cornfield.'

$\mathrm{W}^{\top} \mathrm{e}$ have no evidence of the fact, but doubtless the difference between a crow and a rook was explained to Washington Irving by a competent friend when he visited Bracebridge Hall, and this fact should be impressed upon the minds of those fair ladies who, when returning from their walks, describe the vast numbers of crows they have seen congregated upon a certain spot, the aforesaid crows being of course rooks, whose cawing the amiable Cowper duly appreciated in his description of country sights and sounds when he said :-

But cawing rooks, and kites that swim sublime In still repeated circles, screaming loud, The jay, the pie, and e'en the boding owl That hails the rising moon, have charms for me.

With a head crammed full of such and similar ideas, the writer pictured to himself an old country house full of agreeable old recollections, associations, and imaginations, in such an old place where-

The drudging goblin sw'sat,

To earn the cream-bowl duly set: 
tinction

d-estab-

$k$, that

mind ;

$f$ vaga-

country

against

d they

ubtless

as ex-

friend

should

s who,

e vast

ipon a

rooks,

ciated

when

inilar

untry

tions,

When in one night ere glimpse of morn,

His shadowy flail had threshed the corn,

That ten day labourers could not end;

Then lays him down the lubber fiend,

And stretched out all the chimney's length,

Basks at the fire his hairy strength;

And crop-full out of door he flings,

Ere the first cock his matin sings.

These were the kind of associations that flitted across his mind as appropriate to such a scene, according to poetic legendary lore, in the old abode he was about to visit, but carrying with him the same pang of sympathy described by Bishop Corbett :-

Farewell rewards and fairies,

Good housewifes now may say,

For now fowle sluts in dairies,

Do fare as well as they;

And thoughe they sweepe their hearthe no lesse,

Than maids were wont to do,

Yet who of late for cleanlinesse,

Finds sixpence in her shoo?

The growth of such ideas had been aided by a photograph heading the letter of invitation, which depicted an old house of an eariy period smothered in ivy, and crowded up with luxuriant growing trees; and this turned out to be the case when the house itself was finally reached; but, before then, the carriage stopped at the gate of an ordinary field, through which there was a straight roadway, extending for about half a mile, and at the end of this road stands Hall.

The field was as level and bare as the palm of I. 2 
one's hand, and all the previous occupants of the old Hall had been quite content to approach it by this uninteresting, straight road, not one appearing to have conceived the idea of making an approach worthy of the building, which might easily have been done with horse-chesnut trees, and a handsome avenue created almost immediately, it being in such cases as these that fast-growing trees could be cunted upon for giving an immediate effect, and an avenue of horsechesnut trees in full bloom is a sight worth seeing.

Broad-leaved Timber-trees suitable for Landscape Decoration and good Soils. - The third main division may be properly made to include all the broad-leaved timber-trees which, for the most part, require good land, and which do not thrive in either low-lying situations, which are extremely moist, or in those elevated districts where the Scotch pine would flourish, but where the oak would become dwarfed and stunted; and may be said to embrace the oak, ash, beech, Spanish chesnut, elm, hornbeam, locust, plane, walnut (which, although generally classed with fruittrees, yet makes a beautiful timber-tree), and the birch. The latter, however, will thrive upon a mountain-side, amidst shattered débris, in situations favourable to its growth; yet with this exception, perhaps, the others that have been enumerated all require soil of a tolerably good quality to grow to perfection, and display that embowering appearance which are characteristic of the broad-leaved timber-trees of Britain. 
the old by this o have thy of e with reated these on for horseing.

dscape ivision leaved good -lying those would varfed , ash, plane, fruitbirch. -side. to its thers of a and are es of

As landscape ornaments these are unequalled, the ash being clothed with pendulous masses of foliage, which bows gracefully to the breeze; the oak forming a picture of massive strength and grandeur; while the acacia, or locust-tree, both on account of foliage and flower, is a very beautiful object, and a beech-tree, especially after showers of rain, when the sun shines upon its glistening leaves, is perhaps one of the most beautiful objects of inanimate nature, so called; while the plane-tree, in a sheltered park, is luxuriantly clothed in profuse foliage, and becomes an object of sylvan loveliness that it is not possible, perhaps, to surpass.

Trees and Shrubs for Arboricultural Decoration.The fourth division may be conveniently classified as embracing trees and shrubs which are commonly used for arboricultural decoration, some of which in certain positions never attain a very large size, but when occupying situations that are peculiarly favourable to their growth, form trees of no despicable magnitude, such as the holly, yew, cypress, laburnum, lilac, wild cherry, mountain ash, spindle-tree, evergreen oak, almond, hazel, arbor vitæ, various laurels, varieties of thorn, \&c., \&c., including evergreens that are well adapted to grow under shade, as the common juniper, box, privet, \&c. (amongst the latter, holly and yew being included).

We have roughly classed trees in the divisions enumerated in order to furnish a definite plan for the proper arrangement of 'the subject under distinct 
headings, so that we may give a full description of each, and the best methods that are used in their cultivation and propagation, according to the most approved practice that is followed in various districts of the kingdom. 
tion of

their

most

istricts

\section{CHAP'TER IV.}

CONIFEROUS TREHS.

TAE GCOTOH PINR-DETERIORATION OF THE GCOTCK PINE-THE PINES OF NORTHERN WUROPB-THE SLIDE OF ALPYACH-PRODUCE OF BCOTCH PIND PLANTATIONB-OBTALNING THE BEIDS- SOWING TII SEEDSCULTIVATION-THE OLUATER PI OR PINEASTRR-CULTIVATION-THE CORSIOAN PINE-CULTIVATION - LE BTONE PINE-COLTIVATION-THE WHITE, OR WEYMOUTH PINE-LUMBERING-LABOURER TAAVING 'THE BIGGBST WHAAT FARM IN AMERICA' FOR LUMBFR-WORK,

The Coniferw, or Pine tribe of trees, is perhaps the most important of any for the purposes of the planter, embracing as it does a well-defined order, being all evergreens, excepting the larch, which is deciduous, and the gingo; the most important genera for commercial purposes for the sake of their timber being Pinus, the pine; Abies, spruce; and Larix, larch; there being ten other subsidiary genera, which we shall refer to in detail.

Of these three, the timber from the genus Pinus - especially in the instance of the Scotch pine-is produced of the hardest and best quality when grown upon poor soils in great aititudes; so that in most instances the colder the situation, and the slower the growth of the tree, the harder and more durable the timber becomes. And this fact is so completely attested, even in individual instances, that it is by no 


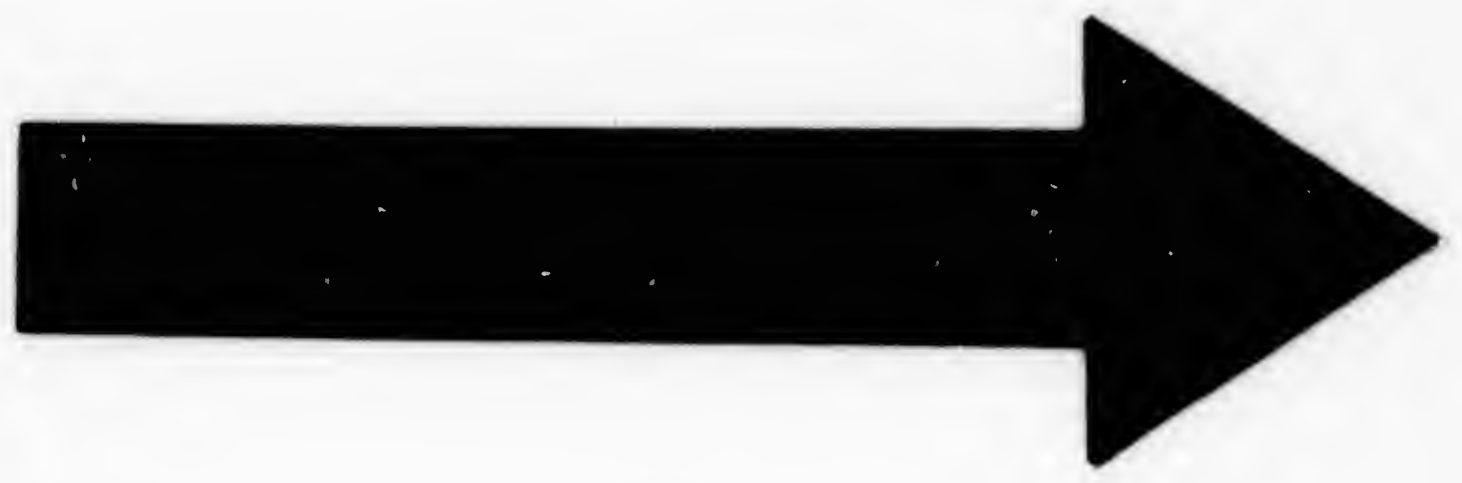




\section{IMAGE EVALUATION TEST TARGET (MT-3)}
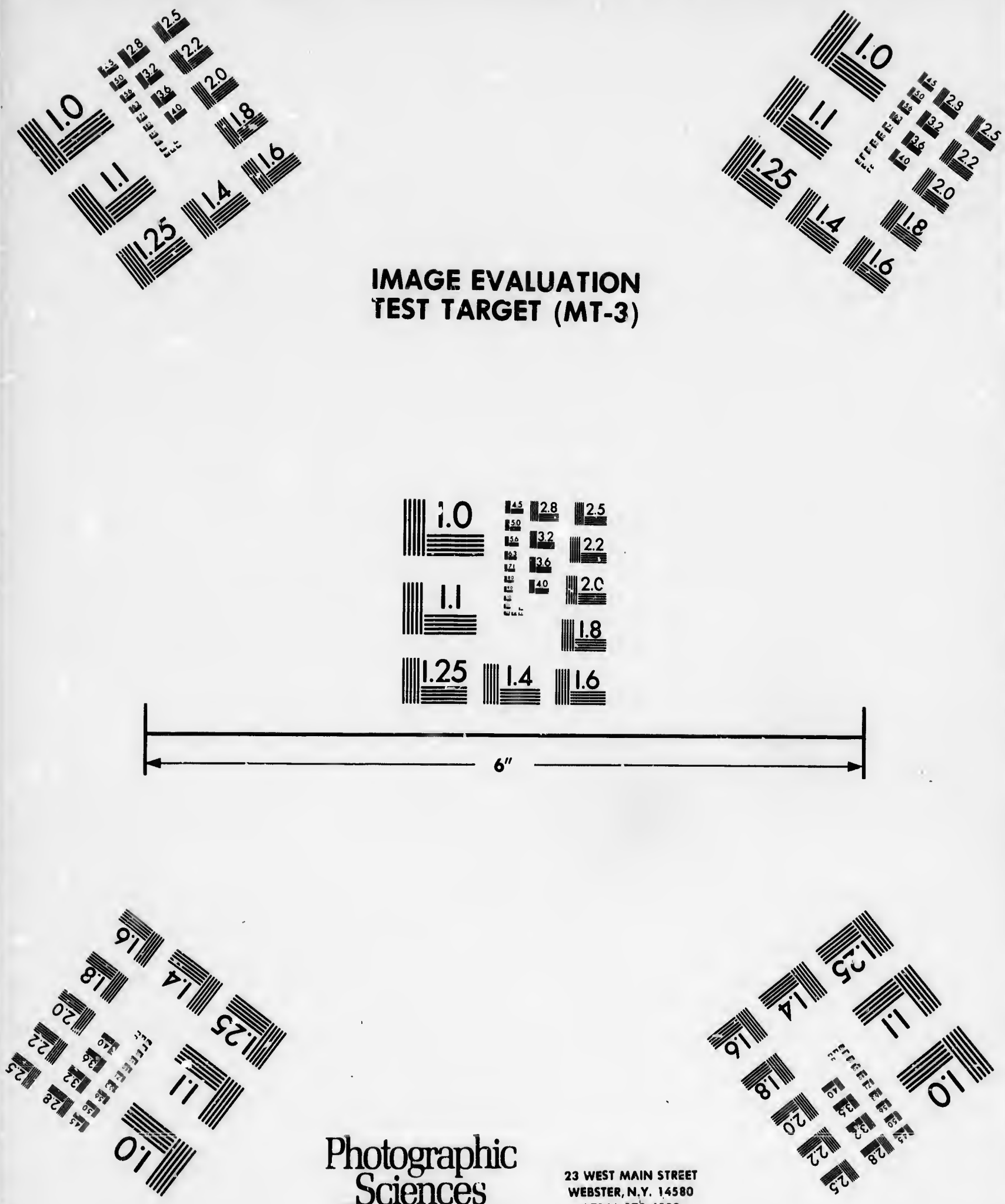

Photographic Sciences

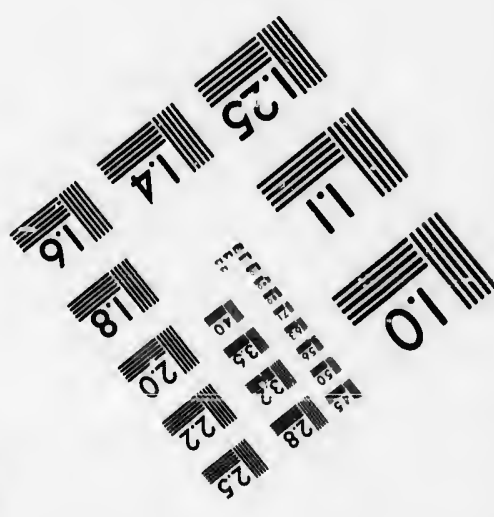
Corporation 

means uncommon to find the wood of a common pine hard and red which faces the north, while the remaining half of the tree which enjoys a southern exposure, though considerably thicker from the pith to the bark, has become soft, spongy, and white in colour ; and as the Scotch pine affords a remarkable instance of what may be termed degeneracy of quality of timber, from being grown in situations not fitted for its best cievelopment, we will speak of this tree first.

The Scotch Pine (P. Sylvestris).-There are several varieties of the Scotch pine, the best timber being that which is hard and resinous, as is found in the native forests of the Highlands of Scotland, and those which grow in a wild state in Sweden and Norway, and some parts of Germany, Russia, and Poland : but when removed from their native districts, and propagated successively in a richer soil and milder climate, it varies very much in foliage and form, and is apt to degenerate greatly in quality; and where mixed seed has been procured, the trees that have been grown upon the same soil have been entirely different so far as the quality of timber was concerned wher they were felled.

Many writers have pointed this out, amongst the first of whom was the Earl of Haddington, who published a 'Treatise on Forest Trees ' in 1760 , where he makes reference to the varieties of the Scotch pine. 'When I cut firs that were too near the house, there were people alive here who remembered when my 
on pine the reouthern he pith hite in arkable quality t fitted is tree

several being in the those orway,

d : but propalimate, apt to d seed grown so far they

st the pubere he pine. there n my

father bought the seed. It was all sown together in the seed-bed, removed to a nursery, and afterwards planted out the same day. These trees I cut down, and saw some of them very white and spongy, others of them red and hard, though standing within a few yards of one another. This makes me gather my cones from the trees that bear the reddest wood, as I said before.'

Deterioration of the Scotch Pine.-The common impression at one time was that the trees varied in quality, not that the seed was various, till at length it became recognised as an established fact that seeds from degenerate trees were largely used in ignorance of their deterioration from their original quality, and of such trees as may. be seen growing in the native forests of Invercauld and Rothiemurchus, which perhaps furnish the finest specimens of this tree in Britain.

At the end of the first quarter of the present century, the attention of the Highland Society of Scotland was directed to the degeneracy of great numbers of plantations of Scotch pine throughout Scotland, and with the object of improving the quality of the timber, which they justly regarded as a subject of national importance, they offered premiums for the collection of the greatest number of seeds of the Scotch pine, from the most celebrated forests in the Eighlands of Scotland, with satisfactory proof that the seeds were all sold in the way of business for the purpose of sowing, or were actually sown ; as well as 
premiums for raisirg the greatest number of plants from these best seeds, the offers extending over a period of ten years or so.

Messrs. Grigor \& Co., of Forres, gained all the premiums, both for collecting the largest number of seeds and for raising the most plants, the result of these measures being that, greater attention was paid to the due obtaining of proper seed and plants, by persons desirous of planting upon a large scale; extensive plentations having been formed by various gentlemen and noblemen, some of them containing several millions of the plants of the true Pinus sylvestris in each.

The late Mr. Don, of Forfar, exhibited specimens of various cones to the Highland Society of Scotland, and pointed out the variations that existed in the several specimens; the variety preferred by him being distinguished by the disposition of its branches, which are remarkable for their horizontal direction, and for the tendency they possess to bend downwards close to the trunk, minute details being published about 1811 , by Mr. Don, who describes several varieties of trees that grew in a wood near to Forfar. But although that gentleman's remarks and description were correct, it does not appear that he was thoroughly aware himself whether this deterioration was due to degeneracy, or to careless cultivation of a bad variety; yet his observations proved of the greatest service, in directing special attention to the matter, and any experienced pine-seed collector could 
now tell from the appearance of the cones, in accordance with his description, whether they had been obtained from the old Highland forests, or from degenerate plantations.

Don contrasted cones of the different qualities, which he numbered 1 and 2 specially, the former being the inferior, or degenerated description, which he describes as being considerably elongated and tapering to the point, the bark of the trunk being very rugged. This variety seems to be but short-lived, becoming soon stunted in its appearance, and it is altogether a very inferior tree. It produces its cones much more freely than variety No. 2 , and in consequence seed-gatherers who are paid by the quantity collected, and not for the quality, would seize upon the former, and neglect the latter.

Of the trees No. 2, or the best variety, the same as grown in the native forests of the Highlands of Scotland, he says: 'Its cones are generally thicker, not so much pointed, and they are smnother than that of variety No. 1. This tree seems to be a more hardy plant, being easily reconciled to various soils and situations. It grows very freely, and quickly arrives at a very considerable size. This is the sort which I conceive might constitute a distinct species, and from the disposition of its branches I would be inclined to call it Pinus horizontalis. May I here be allowed to conjecture that, the fir woods which formerly abounded in every part of Scotland, and the trees of which arrived at a great size, had been 
of this variety, or species. I have certainly observed that the greater part of the fir woods of the present day, and which are so much complained of, are of the common variety, or variety No. 1.

His conjecture was confirmed by the action of the Highland Society of Scotland as before described, the cones of the best kind produced in its native and congenial habitat being short, round, and of a light colour, while those of the third or fourth generation degenerated by cultivation in soil and districts away from its native one, are long and tapering, and there can be no doubt but that the efforts made resulted in a reform in the method of planting the Scotch pine, the seed being now obtained direct from native indigenous forests.

The Duke of Sutherland and Mr. Matheson of Ardross, a good many years back, planted immense numbers of the Scotch pine, as well as Sir George McPherson Grant, Lord Lovat, Mr. Ellice of Glenquoich, The Mackintosh, Mr. Dempster of Skibo, Mr. Mactier of Durris, Sir Thomas D. Lauder, besides a number of other planters in various counties in Fingland and Scotland, by whose endeavours many a barren hillside and desolate waste has become beautified by thriving fir plantations, the effects of which may be seen in districts quite near to London; as the parish of Frensham, a short distance from Farnham in Surrey, where many tracts are of pure sand, unfitted for the purpose of the husbandman, but which in time will be made fertile through judicious planting. 
With respect to the necessity of obtaining the best seed, Sir T. D. Lauder, in his edition of ' Gilpin's Forest Scenery,' gives the following recommendation: 'It should be carefully remembered by planters that sundry wretched and worthless varieties of the Scotch fir have crept into use, which, in some measure, accounts for the miserable appearance of the low-country planted trees. The greatest care should be taken to plant nothing but those trees raised from the seed of the true Pinus sylvestris of the mountains.'

The Pines of Northern Europe.-The rimber of the Scotch pine, commonly though erroneously called the Scotch fir by the authors we have quoted, when produced in the cold elevations of the north of Scotland, is not inferior in quality to that imported from Sweden and Norway, the pine forests of the north of Europe being considered the most valuable on account of the quality of their timber, some of the mountains of Sweden and Norway being covered with pine-trees, as well as the sandy tracts near the Baltic, and in Poland on each side of the river isemel, from whence the timber is imported into England, 'Memel fir' being dealt in to a very considerable extent by English timber merchants.

Dr. Clarke gives some interesting particulars of the extent of the pine forests on the Swedish side of the Gulf of Bothnia.

'At Helsinborg some fir-trees of an astonishing length were conducted by wheel axes to the water side. A separate vehicle was employed for each tree, 
being drawn by horses which were driven by women. These long, white, and taper shafts of deal timber, divested of their bark, afforded the firsi specimens of the produce of those boundless forests of which we had then formed no conception. That the reader may therefore be better prepared than we were for the tract of country we are now to survey, it may be proper to state, in the way of anticipation, that if he cast his eyes upon the map of Sweden, and imagine the Gulf of Bothnia to be surrounded by one contiguous, unbroken forest, as ancient as the world, consisting principally of pine-trees, with a few mingling birch-and junipertrees, he will have a general and tolerably correct notion of the real appearance of the country. If the sovereigns of Europe were to be designated each by some title characteristic of the nature of their dominions, we might call the Swedish monarch Lord of the Woods, because, in surveying his territories, he might travel over a great part of his kingdom from sunrise until sunset and find no other subjects than the trees of his forests. The population is everywhere small, becaus the whole country is covered with wood; yet in the nonsense that has been written about the northern hive, whose swarms spread such consternation in the second century before Christ, it has been usual to maintain that vast armies issued from this land. The only region with which Sweden can properly be compared is North America, a land of wood and iron, with very few inhabitants, "and out of whose hills thou mayest dig 
omen.

imber, ens of ch we r may tract per to s eyes ulf of roken ipally aiperorrect f the ch by lomird of ories, dom jects $n$ is $y$ is has arms bevast with orth few $\operatorname{dig}$

brass ; " but, like America, it is also as to society in a state of infancy.'

Affairs have a good deal clanged since these lines were written in the United States, where the ' lumber' trade has been a good deal developed, together with other mercantile progress, but the same writer gives a description of sawing timber on the banks of the Dal, westward of the Gulf of Bothnia.

'Between Meheda and Elfskarleby, about two English miles before we reached the latter place, we were gratified by a sight of some cataracts of the Dal, which we thought far superior to those of Trolhoetta. The display of colours in the roaring torrent was exceedingly fine : rushing with a headlong force, it fell in many directions, and made the ground tremble with its impetuosity. The height of the fall is not forty feet, but the whole river being precipitated among dark, projesting rocks, gives it a grand effect. A swelling surf continues foaming all the way to a bridge, where another cataract, meeting the raging tide, adds greatly to its fury. Such is the commotion excited, that a white mist, rising above the fall and over the banks of the torrent, rendered it conspicuous long before we reached the river. Close to the principal cataract stood a sawing-mill, worked by an overshot wheel, so situated as to be kept in motion by a stream of water diverted from its channel for this purpose. The remarkable situation of the sawing-mills, by the different cataracts, both in Sweden and Norway, are amongst the most 
extraordinary sights a traveller meets with. The mill here was as rude and as picturesque an object as it is possible to imagine. It was built with the unplaned trunks of large fir-trees, as if brought down and heaped together by the force of the river. The saws are fixed in sets, parallel to each other, the spaces between them in each set being adapted to the intended thickness for the planks. A whole tree is thus divided into planks by a simultaneous operation, in the same time that a single plank would be cut by one of the saws.

'We found that ten planks, each ten feet in length, were sawed in five minutes, one set of saws working through two feet of timber in a single minute. A ladder, sloping from the mill into the midst of the cataract, rested there upon a rock, which enabled us to take a station in the midst of the roaring waters. On all sides of the cataract, close to its fall, and high above it and far below it, and in the midst of the turbulent flood, tall pines waved their shadowy branches, wet with the rising dews. Some of these trees were actually thriving upon the naked rocks, from which the dashing foam of the torrent was spreading in wide sheets of spray.'

Dr. Clarke also speaks of the accidental fires that take place amongst pine forests, and those occasions when fires are sometimes burned in order to make ready the soil for the operations of the husbandman. 'As we proceeded to Hanirange, we passed through noble avenues of trees, and saw some fine lakes on 
h. The object as the unht down r. The her, the d to the e tree is seration, e cut by

length, working ute. A of the ibled us waters. nd high of the hadowy of these rocks, nt was

es that casions o make adman. hrough kes on

either side of the road. Some of the forests had been burned, by which the land was cleared for cultivation. The burning of a forest is a very common event in this country, but it is most frequent towards the north of the Gulf of Bothnia. Sometimes a considerable part of the horizon glares with a fiery redness, owing to the conflagration of a whole district, which for many leagues in extent has been rendered a prey to the devouring flames. The cause is frequently attributed to lightning, but it may be otherwise explained.'

A similar burning of forests is also described by Dr. Clarke, in Lapland, beyond Fornea. 'Some forest 3 were on fire near the river, and had been burning for a considerable time. Mr. Tipping informed us that these fires were owing to the carelessness of the Laplanders and boatmen on the rivers, who, using the boletus igniarius (German tinder) for kindling their tobacco pipes, suffer it to fall in an ignited state among the dry leaves and moss. They also leave large fires burning in the midst of the woods, which they have kindled to drive away the mosquitoes from their cattle s.nd from themselves; therefore, the conflagration of a forest, however extensively the flames may rage, is easily explained. Yet Linnæus, with all his knowledge of the country and customs of the inhabitants, attributed the burning of the forests in the north of Sweden to the effects of lightning. During these tremendous fires, the bears, wolves, and foxes are driven from their retreats, and make terrible 
depredations among the cattle. A bear, having crossed the river about a fortnight hefore we arrived, had killed in one night six cows and twelve sheep, the property of a farmer. We saw their former owner and the place where all this slaughter had been committed, having landed to walk by the side of the river, while our boatmen were engaged in forcing the rapids. The farmer attributed his loss to the burning of the opposite forest, which had compelled the bear to pass the river for food.'

These accounts are interesting for the light tney throw upon the Scotch pine in the Scandinavian forests, the slopes of the mountains and arms of the sea in most of the centr '? parts of Sweden and Norway consisting for the most part of Pinus sylvestris, or what we term Scotch pine, and spruce; the former yielding red or yellow deal, and the latter white.

Pines are generally found growing in forests or clustered together, when they assume a tall and upright form, with few lateral branches except ai top. But when grown singly, the pine branches out into a spreading tree, and presents a more picturesque object, as respects shape and outline, than when grown in masses. Immense districts in North America are covered with them, and we are indebted to Douglas, as before stated, for the introduction of some of the largest species of pine into England, as P. Lambertiana, which was introduced by him in 1827 .

To the difficulty of removal of the felled timber we probably owe the remains of some of the old 
g crossed ived, had heep, the r owner en comhe river, e rapids. $g$ of the to pass

Sht they linavian $s$ of the Norway stris, or former ite. cests or all and ai top. $t$ into a uresque 1 when merica ouglas, me of ambertimber he old

Scotch forests, such as those which remain in the valleys of the rivers that flow northward to the Spey. The estate of Rothiemurchus, to the timber of which we have previously referred, produces trees that are full of turpentine. The timber being of excellent quality, a succession springs up, so that the forest, phœnix-like, possesses the property of continuing itself, a considerable portion of the pine in accessible places having been cut down, and for the most part floated down the river Spey.

In times of drought the workmen collect the trees in what they term a dell or den, and build up a temporary dam, and await the coming of a flood. When this takes place, and the temporary dam is full of water, the dyke is broken, and the trees are swept down with the course of water to the Spey.

The Slide of Alpnach.-A striking instance of the difficulty of transport being overcome in an inaccessible situation was furnished by the contrivance of what was termed the Slide of Alpnach, which was made under the direction of an engineer, M. Rupp. which, on account of the singularity of its construc. tion, is worthy of being ranked with some of the engineering undertakings of modern times, which often excite our surprise to such a remarkable degree.

For ages the deep gorges and rugged flanks of Mont Pilatus in Switzerland had been clothed with impenetrable forests, which were practically useless from a commercial point of view, till M. Rupp con- 


\section{4}

ENGLISH TREES AND TREE-PLANTING.

ceived the idea of launching the pines down an inclined plane, from the top of the mountain to Lake Lucerne, a distarce of nearly nine miles. This was effected by means of a kind of troligh, six feet broad and from three to six feet deep, composed of 25,000 pine trees, its length being 44,000 English feet. This singular contrivance was finished in 1812, and excited universal wonder, as it had to be constructed upon an undeviating line, passing over the summits of rocks, along their sides, over deep ravines or mountain gorges, where it had to be supported by scaffoldings, and in some instances even liad occasion to pass underground. Notwitlistanding these difficulties, which may be readily imagined, they were all overcome in eighteen months from the time the work was first began; and when the work was finished the trees descended from the mountain and plunged into the lake with inconceivable rapidity, the larger pines, which were about 100 feet long, performing the journey of about eight miles and a third in about six minutes.

This extraordinary cuntrivanee was called the Slide of Alpnach, from the name of the commune in which it was situated; but the speculation was finally abandoned as unprofitable when the markets of the Baltic; were opened by the peace, and it was allowed to fall into ruin.

The timber that is grown in these cold situations, especially upon light soils and when planted by natire, is always of the best quality. On rich loans, 
down an a to Lake This was et broad f 25,000

et. This

d excited upon an of rocks, nountain foldings, to pass ficulties, all overork was he trees into the. $r$ pines, ing the bout six

led the nune in s finally of the owed to uations, ted by loanı, though it grows fast, the timber of the Scotch pine becomes inferior, and contaius a great deal of sapwood; while on stony clay it will not thrive, and the timber is almost worthless; but after a certain elevation, and north of the latituce of $55^{\circ}$, it is found to be the most abundant timber in the Continents of Europe, Asia, and America, and there is no other tree that grows so freelv, and produces such valuable timber upon soils of such opposite qualities, as it flourishes on dry and gravelly heaili-covered moors, and its roots find sustenance amongst the fissures of the rocks, and obtain support from apparently the most scanty means of subsistence.

Stagnant water is very opposed to the health of the Scotch pine, yet by reason of its roots ranging near to the surface, it will often be found to answer very well in a comparatively thin stratum of earth above water, where other kinds of trees will not grow when they approach maturity.

Produce of Scotcl Pine Plantations.-The produce of a Scotch pine plantation is valuable in all its stages, from the first thinnings where the branches and leaves are retained, which are applied to useful purposes, such as the erection of screen fences to protect young plantations in exposed situations, for sheep flakes, and other uses, to the succeeding ones, where, the young trees having attained a larger size, can be sold for ' pit-timber,' to prop up the coal mines as the coal is extracted, and for palings, staves, building-laths, \&c., until it reaches a size when it can be cut up into 
planks, and used for house-joinery, and other building purposes, and the timber produced from the best species of Scotch pine fetches about twice the price of the degenerate kind that is sold in the market.

Obtaining the Seeds.-It requires a certain amount of heat to extract the seeds from the cones of the Scotch pine, which get ripe about the end of the year ; but after being exposed to the frosts of the entire winter, a less degree of heat will be required to be applied, and it is therefore considered best to gather them in March.

If only a comparatively small quantity of seed is needed, the seed can be obtained by merely exposing the cones to the sunshine in any sunny situation sloping to the south, when in a few days' time they will open, and the seeds can be sifted out. After the seeds have been collected, they should be moistened with water, which will detach them from the kind of chaff that covers them, after which they are made clean by sifting.

But if a large quantity of seed is required, the heat derived from a kiln will be necessary to obtain them, in which the cones should be placed at a depth of six or eight inches laid with deal about two inches in wilth, with a space of half an inch between, to allow the heat to penetrate, and for the seeds to fall through when the cones are turned. Brick or metal kilns cannot safely be used, as these materials imbibe the heat to a much greater extent than wood, and the 
er buildrom the twice the in the

amount s of the he year; le entire ed to be gather seed is exposing sloping ill open, ds have 1 water, aff that lean by red, the obtain d at a but two etween, s to fall $r$ metal imbibe and the vitality of the seed would be destroyed when it came into contact with the heated bricks or metal.

The heat applied should not exceed $130^{\circ}$ Fahrenheit at any time, and this limit should only be applied for the first four hours, after which the heat should be withdrawn for half an hour, and the cones turned over with a shovel, when the seeds, as they fall through into the pit beneath, should be removed.

The pit is formed two feet or so beneath the level of the fireplace, so that it be always of a comparatively low temperature, to insure the safety of the vitality of the seed. After the first turning, heat should be applied for another four hours, but the temperature decreased, and then removed again, and the seeds taken away as formerly, after the cones have been again turned with the shovel.

About 110 degrees of heat are then steadily kept up, when the remaining seeds will fall from the open cones upon being riddled, and any cones that may remain unopened can be put aside till the next heating process is inaugurated.

Sowing the Seed. - The seed should be sown in well-pulverised soil of rather a dry, sandy description, but of such a nature as will not cake upon its surface from the effects of alternate drought and moisture, the usual time of sowing being about the middle of April in England, and about the first week in May in Scotland. After the intended site of the seed-beds has been well dug and raked, it should be marked off into divisions four feet broad, with an 
alley fifteen inches wide between, the beds thus formed being opened, and the soil which is to form the future covering of the seed raked into the alleys. The seed should then be evenly sown at the rate of one pound to a strip of this bed four feet wide, of ten yards in length, the seeds being covered by a quarter to half an inch depth of the soil; the smaller amount of covering being used when it may be somewhat heavy, and the largest amount when the soil is lightest; but no exact line can be drawn, as much depends whether the surmmer is a dry or a moist one, and the beds require to be well protected from the ravages of birds, till a few weeks after the young plants have shown themselves above ground. Partridges are very destructive, as well as linnets and larks ; but beyond guarding the crop against these depredators, it requires no further attention during the course of two years, beyond weeding, to keep them clean.

Cultivation.-At the age of two years the plants are fit to be inserted into heath-covered or moor land, which affords them a certain amount of protection without smothering them; but where there is a ranker surface vegetation to contend with, they need first to be transplanted into nursery lines ten inches asunder, the plants standing in the rows about three inches from one another. This is a sufficient space to allow them to stand in for one year, but if stronger plants are required, nearly double the space should be allotted to them, where they may remain 
ds thus to form e alleys. he rate wide, of d by a smaller e somee soil is much ist 'one, oun the young Parts and lese deing the them

plants moor protecre is a they es ten about ficient but if space emain

transplanted for two years, which is the extreme period to allow for Scotch pine-seedlings.

Upon a bare and barrer exposure plants that have been transplanted at one year, and have stood in nursery lines for one year more, are found the most tenacious of life, though these perhaps are not nearly so often used, more being planted that have stood in the seed-bed for two years than any other description.

As, however, the plants may be purchased so cheaply from those who make it a business to rear them, who pursue their calling upon a thorough routine system, a good deal of time may be saved by the planter who is anxious to push his work on as quickly as possible, the price of two-year seedling. Scotch pines, of the best quality, that may be relied upon, being only about eighteenpence per thousand; one year old in the seed-bed, and one-year transplanted, about half-a-crown ; two-year old seedlings, one year transplanted into nursery lines, about five shillings, and two-year-old seedlings, two years transplanted, ten shillings. Unless a very large quantity is needed, and the time can be spared, or it is made a matter of business to rear them in the way described, it would answer the purpose of the ordinary planter to purchase the plants themselves of the necessary age required.

Of all soil that is commoniy met with in waste lands, pure bog is the most un $\because$ ngenial to the growth of the Scotch pine, but in almost any other soil - no 
matter how dry-when once it has taken root, it will almost invariably sustain itself.

The Cluster Pine (P. pineaster).- - The cluster pine or pineaster, so termed from the cones being generally in groups which point outward, in a star-like form, whence the name of pineaster, or star-pine, is a grand and picturesque tree, being a favourite object with the Roinan and Florentine painters, and is indigenous throughout the south of Europe and the shores of the Mediterranean, and was introduced into England by Gerrard near the end of the sixteenth century. It resembles other pines that have an extended geographical range, in consisting of many varieties.

It requires a deep, dry, sandy soil, which is indispensable for its growth, as in a rich or wet soil it will not endure the frosts of winter, striking its roots to a very great depth in loose sand, which may be found many yards in length at times. It grows with great rapidity, generally attaining the height of twenty feet in thirty years, frequently growing a couple of feet in the course of a single summer. It most commonly assumes a handsome, pyramidal form, distinguished by its light green foliage and clustering habit of growth, caused by bare spaces on the branches, which have produced male catkins, and as leaves do not grow here again, the entire foliage presents a kind of tufted appearance.

On poor sandy soil, quite unfitted for the purposes of ordinary vegetation, the pineaster has proved a 
most valuable tree to the planter, the most wonderful results having been obtained from it in sea-side planting, which has lately especially attracted much notice, the definite results of certain plantings being now seen that were effected a sufficient number of years back to allow the growth of the timber and the progress of the plantations to be seen and estimated.

Some of the most thriving sea-side plantations that are now to be found were planted on the land of Sir Thomas Fowell Buxton before alluded to, situated at the northern extremity of the county of Norfolk, which were formed in 1841-42-43-44, amongst other trees the pineaster being a very noticeable object.

Until comparatively of late years sea-side planting was entirely neglected and overlooked; yet an example of most successful sea-side planting has been furnished to us by our neighbours across the Channel, evidenced by the report of the commission appointed by the French Government to report on the pineaster foresis formed by M. Bremontier of the Administration of Forests, who in 1789 commenced his useful work at the Gulf of Gascony, which was published in 1811 (to which we shall again refer under another heading of our subject, that of plantations). The products of these plantations and others on the sands of Bordeaux, and between that city and Bayonne, constituting the principal living of the inhabitants, who are mostly supported by the business of pre- 
paring resin and tar, which these plantations yield, and the conversion of a tract of drifting sands into several hundred square miles of thriving forest, has been justly regarded as a great triumph of arboricultural skill.

Cultivation.-The pineaster is raised in a similar manner to the Scotch pine, the seeds being covered with soil half an inch in depth, but it is the most difficult of any of the conifere to remove, perhaps, which arises from its long and naturally bare roots, two-year seedling plants seldom taking root when removed.

It is necessary, therefore, to transplant seedlings that have stood for one year, and let them stand in nursery lines for another year, so as to be two years old, which are the only kind that can be relied on for planting successfully. But this peculiarity of organisation-different to that of most trees-which causes the plant to be removed safely cily with great difficulty, is the means of adapting it for being successfully grown from seed sown in the sand, as its long roots strike readily to a great depth, and spreading themselves widely, they act as anchors in supporting the seedling plant, and in seasons of drought are enabled to procure their sustenance from a longer distance than other kinds, and possess a better safeguard against the casualties of a shifting surface.

A conspicuous and ornamental variety, P.P.foliis variegatis, is propagated by inarching on any of the common kinds. One of the best of the ordinary 
yield, ds into st, has oriculimilar vered most rhaps, roots, when dlings nd in years ed on ty of vhich great sucas its readsupught nger safe-

foliis the nary

pineaster trees, $P$. $P$. escarenus, was introduced into this country by the Earl of Aberdeen in 1825 from the south of France.

The Corsican Pine (P. laricio).- This tree is nearly allied in its character to the Scotch pine, but is altogether a larger and handsomer tree, growing wild on the summits of the highest mountains of the Island of Corsica, as well as in other parts of southern Europe and the west and north of Asia. In its native habitat it frequently attains the height of 140 feet, but it does not, like the Scotch pine, affect the poorest soils, nor is it found in such high altitudes as the latter.

It was introduced into England about the middle of the eighteenth century, and produces a white timber which is not held in much esteem in England, being soft, and more fit for packing cases and other subsidiary purposes than for the more important requirements of joinery, though it has been described, when grown in Corsica, as producing weighty and resinous wood, quite equal to, if not superior, to the Scotch pine; but it has been cultivated only to a small extent in England, except as an ornamental tree, one standing at Kew nearly ninety feet high.

The Black Pine of Austria (P. L. Austriaca).This pine-tree, commonly seen in Austria and other parts of Germany, was not cultivated in this country until 1835, and produces a strong resinous timber of a superior description, being of robust growth in 
soft soils of opposite qualities. In its native country it frequently attains a height of 100 feet.

Cultivation.-The seed has been chiefly imported into England that has been used for the propagation of this species, the method of treatment being the same as that pursued with the Scotch pine; but as its roots are liable to grow in a more straggling fashion than those of the latter, it is found that the strongest and most successful plants are obtained by allowing the seedlings to stand in the seed-bed for one year, and then transplant them into nursery lines, where they may stand one or two years, according to circumstances, and the situation they are intended to occupy.

The Stone Pine (P.pinea).-The stone pine is very commonly met with in the south of Italy, the extensive forest at Ravenna being of this species, and it is the tree very commonly planted near the villas of Florence and Rome, where, the seeu's being edible, are eaten by all classes, their taste resembling somewhat that of almonds, with a slightly turpentine flavour, which is considered by many to be very agreeable to the palate, while they are extremely nutritious.

While forming the most ornamental tree in the landscape scenery of Italy, it is far too tender for cultivation as a forest tree in this country, and is consequently grown merely as an ornamental plant. In Naples the variety $P$. $P$. fragilis is cultivated for the sake of its fruit, which is encased in a thin shell 
easily broken, but those of the common kind are contained in a hard shell.

In this country the tree requires to be sheltered without being confined, and grows best in a dry, sandy soil, in the neighbourhood of the sea. It was introduced into England early in the sixteenth century.

The Siberian Pine (P. cembra), as well called the Cembrian pine, also produces edible seeds, and forms part of the regular food of the peasantry of Switzerland in those districts where these trees abound. It is identical with the tannenbaum of Byron's Childe Harold and the aphernousli pine of Harte, growing higher up the Alps than any other pine-tree, being found at elevations where larch refuses to grow, and is a native of the Alps, Siberia, Switzerland, Italy, and other mountainous districts, dwarf varieties of the $P$. sylvestris being often found growing with it.

It was introduced into this kingdom about the end of the last century by the Duke of Argyle, the timber being finely grained and very fragrant. On this account the peasants of the Tyrol make a variety of carved ornaments of the wood, which are sold amongst the lower orders of Switzerland, who are partial to the resinous perfume it exudes, and, being very soft, with scarcely any grain, it is easily worked.

The tree yields crops of cones at Kew, Witton, Dropmore, and other places, and is very hardy, there being several varieties. 
Cultivation.-The method of cultivation is much the same as that followed in the case of the Scotch pine, the seeds being sown half an inch under the surface, but they do not vegetate until the second soring, and when they do make their appearance the plants are remarkable for the slowness of their growth. They should be transplanted into nursery lines after standing for two years in the seed-bed.

The tree rises erectly, with a smooth bark, having leaves of a fine green, silvery aspect, and although growing slowly when young, makes much more rapid progress in after-years, retaining its lateral branches down to the ground in a very conspicuous manner.

The White or Weymouth Pine (P. strobus).-This valuable tree is a native of America, abounding on the hillsides from Canada to Virginia, being sometimes found in the State of Vermont standing 150 feet high, having a diameter of from three to five feet. From having been planted to a considerable extent by Lord Weymouth upon his estates in Wiltshire, it came to be called the Weymouth pine, owing its name of white pine to the perfect whiteness of its wood when freshly exposed, attaining its greatest dimensions in the upper part of New Hampshire, the State of Vermont, as before said, and those tracts of country situated near the source of the St. Lawrence, where it figures as one of the most ancient and majestic inhabitants of the North American iorests, being seen at long distances towering above the heads of surrounclin trees, growing extensively between 
much

Scotch

ler the second

ce the rowth. $s$ after

laving hough rapid inches ier.

-This ng on some150 e feet. xtent ire, it $g$ its of its eatest e, the? cts of ence, marests, leads ween

the parallels of $43^{\circ}$ and $47^{\circ}$, being the first tree to take possession of barren districts, and most hardy in resisting the rough gales which blow from ofl the ocean.

Almost incredible quantities of this tree have been felled since the commencement of the present century in North America, but the conditions under which those persons operated have changed very much of late years since the development of the railway system in the United States. Formerly the persons who engaged in this branch of industry were of that class which were led and influenced by a roving disposition, for whom the rough life followed had a positive charm, rather than the desire of amassing wealth, and the practice used to be for them to traverse these vast solitudes in every direction during the summer in small companies, so as to ascertain where the pines abounded.

After cutting the grass and converting it into hay for the support of the cattle they intended to employ in the course of their future labour, they returned home, and at the beginning of winter would enter the forest again, and establish themselves in winter quarters, in huts covered with bark, in which they lived with a certain degree of rough comfort, though the cold was often intense, and the mercury remained for several weeks from $40^{\circ}$ to $45^{\circ}$ below the point of congelation. With the game of the forest to subsist upon, plenty of tobacco, and some jars of strong liquors, it may readily be imagined that many wild 
business they follow, is entirely different from that of the other inhabitants of North Anerica. Several of these people form what is termed a "lumbering party," composed of persons who are all either hired by a master labourer, who pays them wages and finds them in provisions, or of individuals who enter into an understanding with each other to have a joint interest in the proceeds of their labour. The necessary supplies of provisions, clothing, \&c., are generally obtained from the merchants on credit, in consideration of receiving the timber which the lumberers are to bring down the rivers the following summer. The stock deemed necessary for a lumbering party consiste of axes, a cross-cut saw, cooking utensils, a cask of rum, tobacco and pipes, a sufficient quantity of biscuit, pork, beef, and fish, peas and pearl barley for soup, with a cask of molasses to sweeten a decoction, usually made of shrubs or the tops of the hemlock-tree, and taken as tec. Two or three yokes of oxen, with sufficient, hay to feed them, are also required to haul the timber out of the woods.

- When thus prepared, these people proceed up the river, with the provisions, to the place fixed on for their winter establishment, which is selected as near a stream of water and in the midst of as much pine timber as possible. They commence by clearing away a few of the surrounding trees and building a camp of round logs, the walls of which are seldom more than four or five feet high : the roof is covered with birch bark, or boards. A pit is dug under the 
camp, to preserve anything that is liable to injury from the frost. The fire is either in the middle or at one end; the smoke goes out through the roof. Hay, straw, or fir branches are spread across or along the whole length of this habitation, on which they all lie down together at night to sleep, with their feet next the fire. When the fire gets low, he who first awakes or feels cold springs up and throws on five or six billets, and in this way they manage to have a large fire all night. One person is hired as a cook; whose duty it is to have breakfast ready before daylight, at which time all the party rise, when each takes his morning, or the indispensable dram of raw rum, immediately before breakfast. This meal consists of bread, or occasionally potatoes, with boiled beef, pork, or fish, and tea sweetened with molasses. Dinner is usually the same, with pea-soup in place of tea, and the supper resembles breakfast. These men are enormous eaters, and they also drink great quantities of rum, which they scarcely ever dilite. Immediately after breakfast they divide into three gangs, one of which cuts down the trees, another hews them, and the third is employed with the oxen in hauling the timber, either to one general road leading to the bank of the nearest stream, or at once to the stream itself. Fallen trees and other impediments in the way of the oxen are cut away with an axe.

'The whoie winter is thus spent in unremitting' labour. The snow covers the ground from two to three feet from the setting in of winter until April; 
and, in the middle of fir forests, often till the middle of May. When the snow begins to dissolve in April the rivers swell, or, according to the lumberers' phrase, the freshets come down. At this time all the timber cut during winter is thrown into the water and floated down, until the river becomes sufficiently wide to make the whole into one or more rafts. The water at this period is exceedingly cold, yet for weeks the lumberers are in it from morning till night, and it is seldom less than a montlı and a half from the time that floating the timber down the stream comnences, until the rafts are delivered to merchants. No course of life can undermine the constitution nore than that of a lumberer and raftsman. The winter snow and frost, although severe, are nothing to endure in comparison to the extreme coldness of the snow-water of the freshets, in which the lumberer is day after day wet up to the middle, and often immersed from head to foot. The very vitals are thus chilled and sapped, and the intense heat of the summer sun, a transition which almost immediately follows, must further weaken and reduce the whole franie. To stinulate the organs, in order to sustain the cold, these men swallow immoderate quantities of ardent spirits, and habits of drunkemness are the usual consequences. Their moral character, with few exceptions, is dishonest and worthless. I believe there are few people in the world upon whose promises less faith can be placed than on those of a lumberer. In Canada, where they are longer in bringing down their 
rafts, and have more idle time, their character, if possible, is of a still more shuffling and rascally description. Premature old age and shortness of days form the inevitable fate of a lumberer. Should he even save a little money, which is very seldom the case, and be enabled for the last few years of his life to exist without incessant labour, he becomes the victim of rheumatism and all the miseries of a broken constitution. But, notwithstanding all the toils of such a pursuit, those who once adopt the life of a lumberer seem fond of it. They are in a great measure as independent, in their own way, as the Indians.

'In New Brunswick, and particularly in Canada, the epithet "lumberer" is considered synonymous with a character of spendthrift, and villanous and vagabond principles. After selling and delivering up their rafts, they pass some weeks in idle indulgence, drinking, smoking, and dashing off in a long coat, flashy vaistcoat and trousers, Wellington or Hessian boots, a hand'kerchief of many colours round the neck, a watch with a long tinsel chain and numberless brass seals, and an umbrella. Before winter they return again to the woods, and resume the pursuits of the preceding year. Some exceptions, however, I have known to this generally true character of the lumberers. Many young men of steady habits, who went from Prince Edward's Island and other places to Miranichi, for the express purpose of making money, have joined the lumbering parties for two or three 
years, and, after saving their earnings, returned and purchased lands, on which they now live very comfortably.'

A gond many years back it was suggested that, what with the indiscriminate clearings of the agricultural settlers, and the conflagrations that occasionally take place, after no very great length of time North America may possibly no longer continue to be an exporting country for timber. At times, it has been explained, forests are injudiciously set on fire by the settlers, to save the labour of cutting, and partially burning, by which indiscriminate method the land is not properly cleared, and is the occasion of a strong and noxious weed, called the 'fire-weed,' springing up, which exhausts all the fertility of the ground, these conflagrations sometimes raging to an enormous extent, producing the most fearful destruction to life and property. McGregor describes one of these destructive fires that raged upon one occasion in New Brunswick.

'In October 1825, upwards of a liundred miles of the country on the north side of Miranichi River became a scene of the most dreadful conflagration that has perhaps ever occurred in the history of the world. In Europe we can scarcely form a conception of the fury and rapidity with which the fires rage through the American forests during a dry lot season, at which time the underwood, decayed vegetable substances, fallen branches, bark, and withered trees are as inflammable as a total absence of moisture cau 


\section{4}

ENGLISH TREES AND TREE-PLANTING.

make them. When these tremendous fires are once in motion, or at least when the flames extend over a few miles of the forest, the surrounding air becomes highly rarefied, and the wind naturally increases to a hurricane. It appears that the woods had been on both sides of the north-west branch partially on fire for some time, but not to an alarming extent, until October 7, when it came on to blow furiously from the north-west, and the inhabitants on the banks of the river were suddenly alarmed by a tremendous roaring in the woods, resembling the incessant rolling of thunder, while at the sume time the atmosphere became thickly darkened with smoke. They had scarcely time to ascertain the cause of this phenomenon before all the surrounding woods appeared in one vast blaze, the flames ascending more than a hundred feet above the tops of the loftiest trees, and the fire, like a gulf in flames, rolling forward with inconceivable celerity. In less than an hour Douglastown and Newcastle were enveloped in one vast blaze, and many of the wretched inhabitants, unable to escape, perished in the midst of this terrible fire.'

From the particulars that were ultimately gathered respecting this fire, it turned out that several hundred lives were lost in Newcastle, Douglastown, and Fredericton; that nearly all the lumberers engaged in following their occupation in the woods perished, and in various parts of the country all the cattle were destroyed, the loss of property for a comparatively new country being immense. 
Labourers leaving the "biggest wheat farm in America for "lumber work." - From the descriptions that have been given of the vast destruction of timber in the United States, it might naturally be supposed that the trade of the 'lumberer' must be on the decline. Yet according to the very latest reports, up to the time these lines are being written, the trade is being plied as briskly as ever, only of course at distances much further afield from the chief American cities. An account appeared in 'The Times' of October 30,1879 , furnished by a special correspondent, under the heading of the biggest wheat farm in America, upon which it appears customary to discharge nearly all the hands upon the first approach of winter, the said hands readily finding ' lumber work.'

We will give a short extract from the letter in question, which contains many interesting particulars. 'The United States, although famous for great business undertakings, have not inany large wheat-growing farms. Throughout the eastern, middle, and even the north-western states, the ordinary grain-farmer seldom possesses more than 200 acres. But here at Casselton, in Dakota Territory, in the valley of the Red River, is a striking exception-a farm of 75,000 acres, held by Mr. Oliver Dalrymple. Four years ago this enormous farm was a portion of the farreaching prairie wilderness. No evidences of human life were visible. Prairie fowls, snipe, jack rabbits, the prairie squirrel, or gopher, were the inhabitants; while wild ducks and gcese congregated in creeks or 
ma.shy spots. A few yoars previously, buffaloes and badgers were common, and on the untilled prairie their whitened bones lie thickly strewed. Some of the directors of the Northern Pacific Railway had acquired these lands, and wisely appointed Mr. Oliver Dalrymple their manager, with a half share in the concern. Mr. Dalrymple brought to his serious task a goodly experience, acquired in successfully farming 6,000 acres at Lake Elmo, near St. Paul, Minnesota.

' On Friday the members of the Royal Commission, Messrs. Read and Pell, your commissioner, and a party under the guidance of Mr. James H. Drake, assistant manager of the St. Paul and Sioux Railway Company, were most hospitably received by $\mathrm{Mr}$. Dalrymple, were driven for miles over this vast prairie farm; examined its dark, friable, alluvial soil, perfectly free from stones, varying from 12 inches to 20 inches deep, resting upon an argillaceous clay, rich in vegetable remains; gathered information as to the cost of wheat production, and speculated on the performance of continuous wheat-growing. . . . The estate is partitioned into divisions of 5,000 acres, each under the management of a divisional superintendent, who has under hin two foremen, one of whom, on horseback, accompanies his ten or fifteen teams to work, sees to the ploughing or drilling, observes and reports as to the behaviour of the men, the condition of the animals, and the efficacy of the machinery. Each division has two or more sets of bnildings, and in connection with the principal 
homestead of each farm are the quarters for the men -large wooden barrack-rooms, sometimes over the stables, comfortably warmed with stoves, where fifty men sleep in busy times, two in a bed. Hard by are the kitchens, each with the capacity to provide for the wants of 100 men, presided over by the cook and his mate, who, on requisition through the foreman, draw supplies from the stores-flour for bread, puddings, and cakes, beef, which costs fresh fully $3 d$. per lb., pork, bacon, cheese and butter, tea and coffee, and other good things, \&c., \&c. . . . During harvest and threshing, which is done out of the field, as many as 600 men are frequently employed. Even with this great accession of labourers, work proceeds systematically. No rows occur; brawling and fighting are extremely rare, but when they do occur, it unfortunately is usually on Sunday. . . . So soon as frost prevents ploughing, the whole of the men on the farms are clismissed, with the exception of the divisional manager and about ten men, who each look after about forty mules or horses, feed and water them, and turn them into a yard for a quarter of an hour's exercise night and morning. Hard as such a wholesale dismissal would be in Great Britain, it is no hardship here, for these men readily find lumber work in the forests. It is obviously an enormous boon thus to get rid of men whom the farmer cannot profitably employ during the five winter months,' \&c., \&c.

We have given these short extracts from the very 
interesting letter in question, for the purpose of showing that 'lumbering' still goes on as continuously as ever in the United States, and to show that, in the face of the enormous supplies of wheat inat will doubtless be sent to us from America in the future, added to the large quantities received from other parts of the world, as France, who sends us her surplus, when there is one, of wheat, the north of Europe, and many other countries which it is unnecessary to specify ; that there is not nuch chance of successful competition by the English wheat-grower of the future, and many districts might be inore profitably dealt witl by judicious tree-planting, especially fruit-trees, vast quantities of fruit being imported into England from the Continent, which might just as well be grown in this country profitably as not, together with dairy produce, and vegetables, for which there is an ever-increasing demand, especially for many of the finer sorts, the cultivation of which is a good deal neglected; and in support of our argument, as we proceed we shall give an example or two to prove that larger profits have been gained by plantations, when the cost has been deducted for planting, felling, and interest of money, than the rent of the land would have amounted to had it been let out for ordinary agricultural purposes. 


\section{CHAPTER V. \\ CONIFEROUS TREES (continued).}

TEE GIGANTIC, OR LAMBERT'S PINE-THE LOFTY, OR BHOTAN PINE-THE HEAVY-WOODED PINE-LONG-LEAVED INDIAN PINE-DWARF PINESSPRUCE FIRS-CULTIVATION-THE BLACK SPRUCE FIR-BILVER FIRSTRASBURG TURPENTINE-CULTIVATION OF THE SILVER FIR-THE BALM OF GILEAD GILVER FIR.

The Gigantic, or Lambert's Pine (P. Lambertiana).This pine, a native of the north-west coast of North America, was introduced into England in 1827, and named after Lambert, the author of a work on the genus pinus, as a tribute to his labours, is found dispersed over large tracts of country, especially in Northern California, and is a majestic tree of very large proportions, but does not form dense forests like most of the other pines. Douglas, who introduced the tree, measured one that he found prostrate, the length of which was 215 feet, and its cireumference, where it would have stood when upright at three feet from the ground, was fifty-seven feet nine inches!

Some of the cones of this variety which have been imported have been found to measure a foot and a half in length. The plants are quite hardy, and at one year old are capable of sustaining the severest winters, its yearly shoots becoming well matured before winter, its girth being very great in proportion to its 
lieight. The tree bears a considerable resemblance to the spruce fir, and the seeds are eaten when roasted, or pounded into cakes. As its turpentine when partly burned loses its peculiar flavour, and acquires a sweetish taste, it is eaten as a substitute for sugar by the natives where the tree is indigenous.

The Lofty, or Bhotan Pine (P. Excelsa).-This tree is a native of the Himalayan Mountains, and was introduced into England also in the year 1827.

The amiable Bishop Heber gives an interesting account of the pines of the Himalayan Mountains in a letter addressed to Lord Grenville, who formed some mosi valuable fir-plantations at Dropmore, in Buckinghamshire, upon a spot which at one time was a most desolate and barren heath, that nobleman having given the prelate a commission to search out any new species of pines in India.

'A visit which I paid to these glorious mountains, in November and December last, was unfortunately too much limited by the short time at my disposal, and by the advanced season, to admit of my penetrating far into their recesses, nor am I so fortunate as to be able to examine their productions with the eye of a botanist.

'But though the woods are very noble, and the general scenery possesses a degree of magnificence such as I had never before either seen or (I may say) imagined, the species of pine which $I$ was able to distinguish were not numerous. The most common is a tall and stately but brittle fir, in its general 
mblance

character not unlike the Scottish, but with a more branching head, which, in some degree, resembles that of the Italian pine.

'Another, and of less frequeut occurrence, is a splendid tree, with gigantic arus, and dark narrow leaves, which is accounted sacred, and chiefly seen in the neighbourhood of ancient Hindoo temples, and which struck my unscientific eye as very nearly resembling the cedar of Lebanon. These I found flourishing at near 9,000 feet above the level of the sea, and where the frost was as severe at night as is usually met with at the same season in England. But between this, which was the greatest height that I climbed, and the limit of perpetual snow, there is doubtless ample space for many other species of plants, to some of which a Dropmore winter must be a season of vernal mildness.'

The reader will perceive by comparison with the passage further on, where a description of Lebanon is given, that the tree described as resembling very much the cedar, grows in a similar position to that occupied by the latter on Mount Lebanon, or nearly 10,000 feet above the level of the sea, yet below the region of snow, whose annual melting is doubtless the occasion of the massive strength and durabilicy of the cedars of Lebanon, which have been made use of as similes by the Hebrew proplets, and are renowned in biblical history.

The Bhotan pine is a very ornamental and hardy tree when grown in this country, ten-year-old plants 


\section{2} ENGIISH TREES AND TREE-PLANTING.

being generally twelve feet high, and growing readily from imported seed.

The Heavy-wooded Pine (P. Ponderosa).-This tree is of a very vigorous habit of growth, producing learling shoots one inch in diameter when only a few years old that measure about two feet long. Its leaves are thickly set, and are from nine inches to a foot long. It was introduced into England in 1826, and though very apt to receive injury from the wind, is perfectly hardy.

There are also a great number of other pine-trees, some dwarf and hardy, and others too tender to be grown without a little artificial aid in England, as the long-leaved Indian pine, which is perhaps the most beautiful of all the genus ( $P$.gerardiana), a native of Nepaul, with seeds nearly an inch long, and although the plants will endure our winters, the climate seems incapable of developing them into full-grown trees; and also many American pines, as Rigida, Banksiana, Pungens, Resinosa, \&c., many of them of great beauty, but too tender and feeble for cultivation as timber trees.

Duarf Pines.-There are also some dwarf pines which bear a somewhat close resemblance to one another, in appearance very much like that of the Scotcl pine, being natives of higl mountains, and found in the Alps, Pyrenees, and other cold exposures, where they are merely bushy shrubs, but in more sheltered situations acquire the stature of low-growing trees. These are P. sylvestris Mugho, P. S. Pumilio, 
I. S. uncimata. The foliage is of a dark green colour and thickly set, being of broad and spreading habit, which fits them for exposed situations, the yearly shoots they make being very short. They all produce resinous hard wood, and it has been suggested that, these varieties may have become dwarfeci, and stunted, from a course of exposure in repeated generations, and that it is possible that, if by an inverse system, these trees were cultivated at a lower altitude with shelter, their eharacter would become gradually altered, and they would assume the shape and contour of loftier pines. In their present form, that is to say, the plants raised fiom the seeds of the cones of these dwarf trees, they are propagated merely for ornament, and offer a pleasing variety in conjunction with other trees.

Spmue Firs (Abies). - The firs, or spruces, are another genus of conifera, which differ from the pine tribe in the form, and position of their leaves, as well as in the general appearance of the trees, the leaves being shorter than those of the latter, and placed singly, instead of in pairs.

There are several species, natives of Europe, Asia, and America, being like the pine, evergreen, but affecting a soft and moist soil, united to a cool climate, rencrally growing erect, with a profusion of foliage, the cones being pendent, and ripening during the year the blossoms are produced.

The Noruay spmuce (A. encelsa).-This is the most common tree of the gemus that is cultivated in this kingdom, and one of the tallest firs indige- 


\section{ENGLISH TREES AND TREE-PIANTING.}

nous to Europe. It rises with very uniform growth, and possesses great beauty of form, assuming a conical shape, and, when planted in soil the best fitted for its constitution, retains its branches, and luxuriant foliage at an advanced age, down to the surface of the ground, being known to reach an altitude of 180 feet, its native habitat being the north of Europe, principally found in Sweden and Norway, Prussia, the north of Germany, and Denmark, and Lapland.

The precise period of its introduction into Britain is not exactly known, but it was noticed by Turner in the Hortus Kewensis in the sixteenth century. The timber is inferior to that of the common pine for durability, and is often found to be very knotty, but it possesses the redeening quality, like the larch, of being equally durable at any age. In growing the Norway spruce-fir for ornament, it is essential that it has shelter, as well as sufficient space, for its beauty will not be fully developed unless it is allowed to stand alone; but when grown in plantations for profit as timber, this is by no means necessary, for the quality of the timber is improved by the trees crowding one another somewhat, when the branches lowest down will become enfeebled, and drop off, pruning never being practised on this species. The tops, or young sprouts, give the flavour to spruce beer, and by incision it yields resin and Burgundy pitch, which is the congealed sap, melted and clarified by boiling it in water. 
growth, a coniitted for ixuriant surface altitude corth of Norway, rk, and

Britain urner in y. The for du, but it irch, of ing the that it beauty wed to $r$ profit for the crowdlowest oruning e tops, er, and which boiling

Cultivation.-The tree blossoms in May and June, and the cones become ripe in the winter of the sams year, when they may be collected either then, or in spring, the seeds being extracted in the same way as that described for the Scotch pine, the method of sowing them being also the same.

After the plants have stood for two seasons in the seed-bed, they are generally from seven to nine inches high, and are then fit for transplantation, but should from any cause the plants not appear to be strong, they may be safely allowed to stand for another summer, and then transplanted; for while no other species admits so well of standing three years in the seed-bed, the fibrous roots of the spruce adapt it for safe removal at that age, when many other kinds of trees, if allowed to stand so long indisturbed, would have developed a strong tap root, plants being sometimes removed to the places where they are intended to stand, direct from the seed-bed, in contradistinction to the usual methods of transplanting into nursery lines.

The ordinary method is, however, to follow this excellent practice, and transplant the seedlings into lines for one or two years, for although one-yearold transplanted plants are seldom much bigger than when they left the seed-bed, they are much hardier, and their roots more fibrous, so that they suffer less from transplantation.

The spruce, on account of its form of making roots, admits of being removed at a greater size than any 
other tree of the same order, though more seldom transplanted.

No amount of frost will hurt the spruce in winter, bnt yet it will not attain a large size in an exposed situation, though it is extremely useful as a nurse to other trees, on account of its numerous lateral branches, and the great shelter its foliage affords.

It derives its support from the surface soil, and though luxuriating in one that is cool and moist, it will grow in a dry, sandy soil, sufficiently well to serve as a protection for other trees during its youth, though it will assume a sickly aspect when it approaches the size of a timber tree.

The Black Spruce Fir (A. nigra).-The black, white, and red spruces are natives of North America, and nearly resemble in their qualities those of Northern Europe, the Black Spruce being considered the most durable, being used in America, where neither oak nor larch can be easily obtained, as knees for ship-building. The black spruce was introduced into Britain by Bishop Compton in the end of the seventeenth century, and is one of the few trees that has attained to a nearly equal height in England, as it does in its native districts; having reached sixty or seventy feet in this conntry, frequent instances occurring of heights of upwards of fifty feet; the indigenous forests of great extent that are to be met with in Lower Canada, Nova Scotia, New Brunswick, and the district of Maine, seldom overtopping it. 
It is not, however, cultivated in this country for the sake of its timber, but is merely used as an ornamental tree, being at once hardy, and possessing rich and dense foliage, affording great shelter and seclusion. It likes a moist soil, and under favourable conditions its lateral branches often strike root into the ground, and form a circle of young plants around the parent tree, somewhat after the same manner (only to a lesser degree) as the celebrated banyan tree (Ficus Indica). This singular tree, belonging to the family of figs, was known to the ancients; Strabo describing it very naturally, that after the branches have extended themselves about twelve feet horizontally, they shoot down in the direction of the earth, and then root themselves, and when these have attained maturity, they propagate inward in the same manner, till the whole circle becomes, as it were, an umbrageous tent, supported by many columns.

Pliny also gives a minute description of it, which Milton has very closely followed in the following lines:-

Branching so broad along, that in the ground

The bending twigs take root, and daughters grow About the mother-tree; a pillared shade

High over-arched, with echoing walks between.

There oft the Indian herdsman, shunning heat,

Shelters in cool, and tends his pasturing herds;

At loop-holes cut through thickest shade.

Southey following also in the same strain :-

'Twas a fair scene wherein they stood,

A greell and sunny glade amid the wood, 
And in the midst an aged Banian grew, It was a good' $y$ sight to see

That venerable tree,

For o'er the lawn irregularly spread, Fifty straight columns propt ite lofty head;

And many a long depending shoot,

Seeking to strike its root.

Straight, like a plummet, grew tov

Some on the lower boughs which erc. ": way,

Fixing their bearded fibres, round ana - wand,

With many a ring and wild contortion wound;

Some to the passing wind, at times, with sway

Of gentle motion swung;

Others of younger growth, unmoved, were hung

Like stone-drops from the cavern's fretted height.

Beneath was smooth and fair to sight,

Nor weeds, nor briars defam'd the natural floor;

And through the leafy cope which bowerea it o'er

Camo gleams of chequered light.

So like a temple did it seem, that there

A pious heart's first impulse would be prayer.

It may be incidentally remarked here that an instance is recorded of one of these singular trees that stood near Mangee, twenty miles to the westward of Patna, in Bengal, which spread over a dianeter of 370 feet, the entire circumference of the shadow at noon being 1,116 feet. The fruit of some of these remarkable trees is very small, not exceeding the size of a hazel nut, and, being of no use, has given rise to the sailor's saying of a 'banyau dinner' when put upon short commons.

The Silver Fir (A. picea).-This is one of the most beautiful of the family of abies, bearing a striking resemblance to the spruce fir, but having leaves of a rich, vivid green on their upper surface, but be- 
neath having two white lines, which run lengthwise on each side of the midrib, and give to it that silvery appearance from which the tree takes its name. The branches diminish in length as they approach the top of the tree, and thus form a regular pyramid.

There are several species, natives of Europe, Asia, and America, the common silver fir (Picea pectinata) being indigenous to Central Europe and the north of Africa, abounding on the lower slopes of the mountains and glens in Italy, Spain, France, and Germany, in the district between the Swiss Mountains and the Black Forest ; on rich, friable, loamy soil, attaining a height of 150 feet.

The wood is light, and but slightly resinous, and is inferior in quality to the common pine, the plant being very tender during the early period of its cultivation, and for the first ten or fifteen years of its life; but after it gets established in a suitable soil, and it reaches the height of eight or ten feet, it grows with a rapidity seldom exceeded by any other of the coniferæ, both in height and girth.

The best soil for developing the timber of the silver-fir is a rich, deep loam that is cool and moist, and often met with along the side slopes of valleys; but it will grow well enough in heavy clay, and in soils of very opposite descriptions. It is tender, and is hurt by slight degrees of frost even, so that it is a tree that requires shelter when young, on account of the buds of the top shoots being unfolded at the same time with those of the lateral branches, which fits it 
adnuirably for vacancies in woods when they occur; on account of the shelter afforded, when the silver-fir hecomes an exceedingly appropriate tree for making good any vacant spots; when many other trees would suffer from this excess of shade, and be injured by it, which, however, would protect the silver-fir from the effects of late frosts.

On this account it is totally unfitted for bare and rough elevations, for which the Scotch pine and larch are so well suited, and for such places are most appropriate; but it grows well with the oak, and they are often associated in plantations togrether. Its wood is generally of a pale yellow colour, the grain being often very irregular, which arises from the unequal character of its growth at different stages of its existence.

Strasburg Turpentine.-It yields a grood deal of resin, and produces the Strasburg turpentine of commerce, which owes its name to the large quantity of turpentine which was made a definite trade of, many years ago, in those parts adjacent to that town, where its preparation used to be extensively carried on. The resinous fluid is obtained from the tunour-like blister's which form under the outer bark, and from other parts of the tree, and forms the turpentine that is specially employed in clear varnishes, and for artists' colours. The essential oil of turpentine is another preparation produced from this tree, which is considered very salutary for sprains and bruises, and the resinous juices are manufactured witlı several articles 
occul'; on

silver-fir

I' making

ier trees

e injured silver-fir

bare and und larch

st approthey are wood is

in being unequal of its

deal of of comuntity of f, many I, where on. The blisters $n$ other that is ' artists' another is conand the articles 


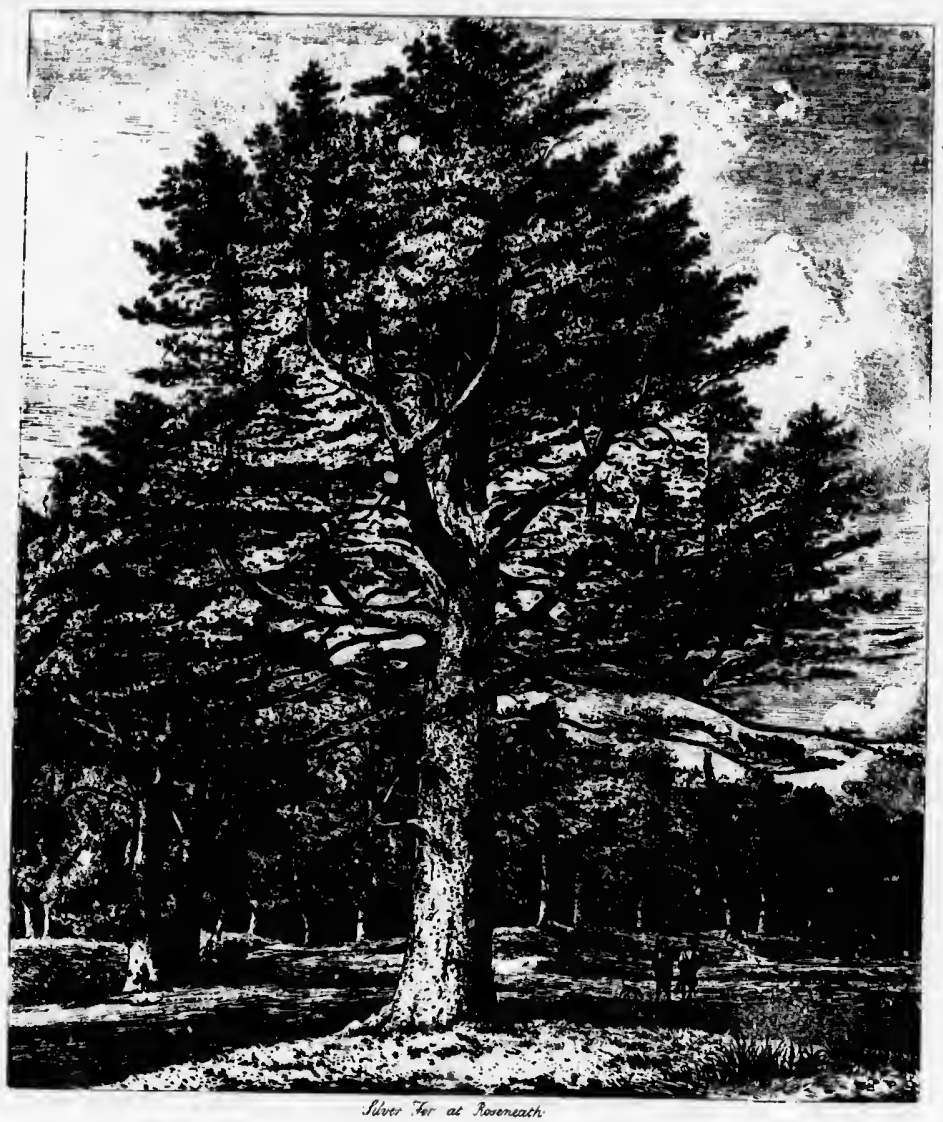


considered to be of great efficacy in veterinary practice, and medicine.

Its produce has been sold both in England and America under the name of balsam, or balm of Gllead, which is the product of an entirely different tree.

Cultivation of the Silver Fir.-The cones become ripe in the beginning of winter, when the scales fall away, which permits of the extraction of the seeds without the aid of artificial heat. The ground should be made fine, and the seeds sown in April, after the manner before described, the plants standing from an inch to an inch and a half from each other in the seed-bed, the seeds having been covered with about half an inch depth of soil. The seed varies in quality in different seasons, when they are at their best being full and plump, a larger quantity needing to be used when they are of inferior quality, so as to ensure enough plants in a given space.

The young plants generally make their appearance above ground about the end of May, and up to this time the seeds should be well protected from the ravages of birds, and a covering is also necessary as a protection against the late frosts, the slightest torch of frost destroying the plants in their early infancy, and this may be ensured by covering the bed with branches of evergreen trees, or broom placed flat on the ground, or by small branches stuck up in the ground pretty thickly, but not so much so as to exclude the air. Some planters use straight straw, which they place across the beds, and to prevent it 
from being blown away they stretch straw ropes across the covering, which they keep in position by pegs stuck into the ground. But even when they have got over their first tender infancy, and se in their second year, the top shoots of the young plants are quickly destroyed by frost, so that a constant shelter should be provided until the second year's growth is matured, when they should be transplanted into nursery lines. Should, however, any of them have been injured by frost, these should be allowed to stand another year in the seed-bed, so as to form fresh tops, which they will do better before they have been disturbed, than afterwards.

Keeping this contingency in view, the site of the seed-bed should be chosen in a sheltered situation, which is better calculated to produce healthy plants than a sunny one, where growth might be stimulated, it is true, but which a late frost might afterwards cut up. The lines should be twelve inches asunder, and the plants a few inches apart, and, after standing for two summers thus, they should be carefully lifted, and either placed in a permanent, sheltered situation, such as in making good bare places in an already established plantation, or wood. as before mentioned, or again be replanted into nursery lines, so as to allow them to become of a large size before they are finally established in their intended positions. A great saving of time is effected by purchasing the plants, instead of raising them from seed, for plants that have been carefully and properly treated seldom exceed a foot in 
es across

by pegs

ey have

in their

ants are shelter cowth is to nurve been o stand sh tops, een dis-

of the tuation, plants ulated, rds cut er, and ing for ed, and $\mathrm{n}$, such blished gain be hem to estabving of tead of been foot in

height at six years of age, but a counterbalancing element of strength is to be found in their roots, which are large and bulky in comparison with their tops; while the diameter of the stems is greater in proportion than the height of the plant.

The Balm of Gilead Silver Fir (P. balsamea).This is a hardier tree when young than the preceding, being of early and rapid growth, at the age of five years or so being twice the size of the common variety, and at ten years perhaps being three times its height; but this rapid progress appears to cause it to lose its vigour, as it seldom lives beyond the age of thirty or forty years, which is no great epoch of time in the life of a first-class timber tree.

Notwithstanding this, on account of its being able to give immediate ornamental effect, it is a most useful tree; its foliage being closely set, and, though shorter, more dense than that of the common silver fir, the leaves being of a dark glistening green on one side, and silvery beneath. In growing, it assumes a pyramidal form, and is a capital tree for shrubberies, or belts of plantations. It requires a deep, moist soil, and to be well sheltered; in light gravelly soils that are quickly affected by the droughts of summer, wearing a sickly aspect, and gradually dying off.

It was introduced into this country by Bishop Compton towards the end of the seventeenth century from America, the resinous substance which it produces being known in its native country as Balm of 
Gilead, or Canadian balsam, a resinous compound which it yields more profusely than any other of the tribe of Conifera, the cones, buds, and bark being often literally smothered in turpentine, which emits a penetrating and odoriferous perfume, that runs freely upon the slightest incision of the trunk, the early decay it is subject to, doubtless, in a great measure, resulting from this circuinstance.

It yields cones abundantly, and is cultivated after the same mamner as $P$. pectinata, or the common silver fir. 
pound

of the being emits runs $k$, the CHAPTER VI. CONIFEROUS TREes (contimued).

THE IARCH - DURABILITY UF LARCH TIMBER-CULTIVATION-CASUALTILS AND DISEASES-THE CEDAR-CULTIVATION-THF INDIAN CEDAR - CULTIVATION.

The Larch (Laric Europcea).-Unlike the rest of the natural order of conifers (with one other minor exception), the larch is deciduous, and, on account of thus sledding its leaves, it is probably often saved from those ill-consequences that often arise from the keen blasts that frequently prove destructive to pines in early spring; and after the common pine, the larch is probably the most valuable tree of the tribe.

Its native locality is the Tyrolese and the Dalmatian Alps, and similar positions on other mountains in Germany, but has been found to answer uncommonly well in Britain, where it now takes rank as a tree of the first importance. Ferard, who in 1596 published a catalogue of trees of native, and foreign growth, in which upwards of a thousand different varieties were specified, gives an accurate description of the larch, which it appears was introduced into England early in the seventeentl century, a definite accomnt of it being given later by Parkinson, an apothecary of London, in 1629, in his 'Paradisus,' 
which, although now so common, he describes then as being a rare tree in England. In 1731 it appears to have become common in gardens in this country, according to Miller's 'Gardener's Dictionary,' published in that year; when its habit, as it clearly appears, was not understood; for in the seventh edition of the 'Dictionary,' published in 1759, it is there related as a matter for surprise that the trees planted in the worst soil, and the most unlikely situations, had thriven by far the best, great numbers of larch-trees having by that time been planted, and were being reared in the different nurseries of the kingdom. At first it was not understood that rich, fertile land, in shaded situations, was not calculated for the larch to put on its best appearance, which requires an open subsoil in an elevated situation, and clear atmosphere; but from this time its requirements became better known, and appreciated, the best specimens ultimately being produced on the slopes of high mountains, contiguous to running streams, in a subsoil offering a ready discharge of moisture.

These elements, the most conclusive to its prosperity, were offered in various parts of Scotland, where, however, the tree does not appear to have been introduced until 1725, or something like a hundred years after its advent in England, first having been planted at Dalwick, in Tweeddale, and afterwards at Dunkeld, Monzie, and Blair, according to the account published in the "Transactions of the Highland Society,' under the authority of the Duke 
then

ppears

untry, publearly venth it is trees situaers of and $f$ the rich, lated hich and lents pecihigh bsoil

proand, lave e a first and ing the lke

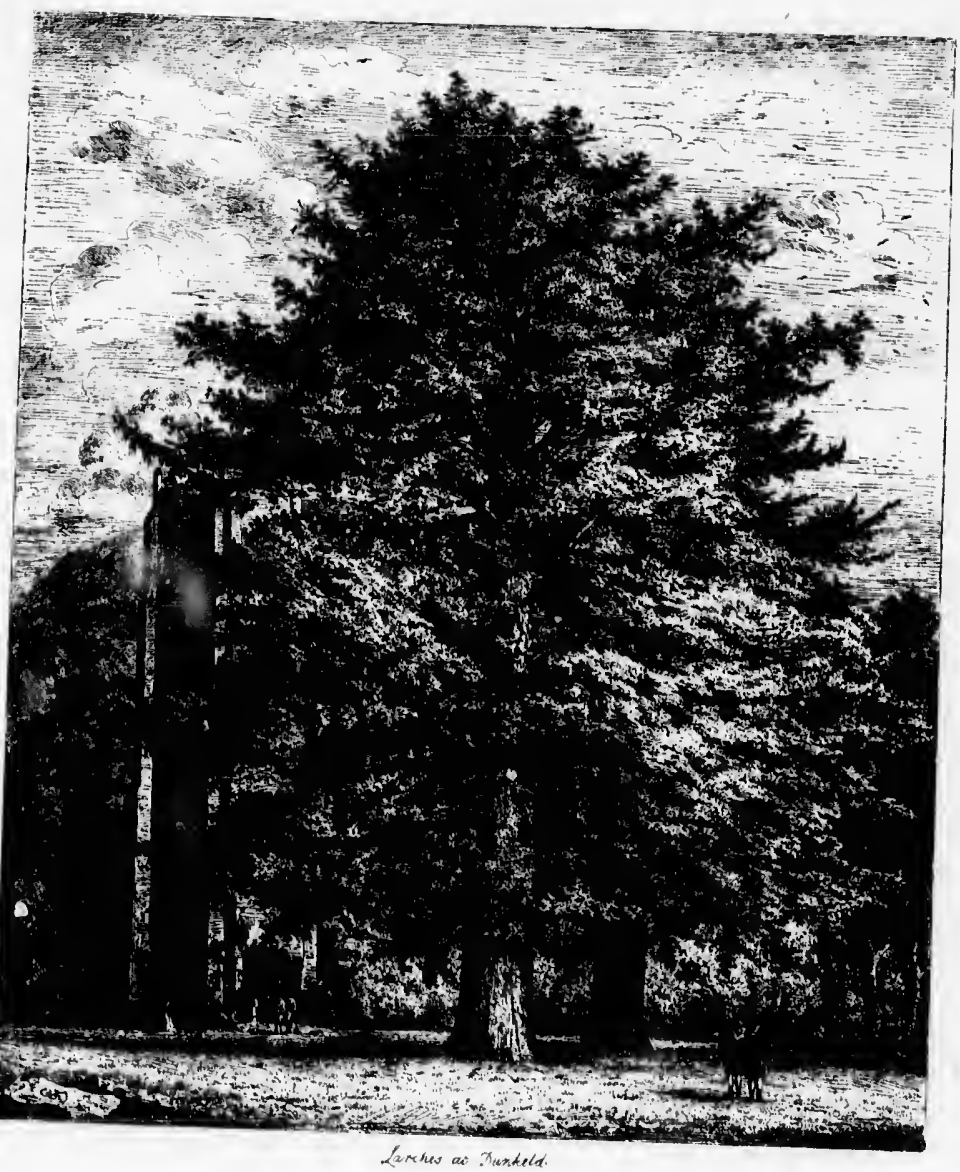



of $A$ thol's trustees, which states that the first larches were brought from London by Mr. Menzies, of Migeny, in 1738, five small plants being left at Dunkekl, and eleven at Blair, in Athol, as presents to the Duke of Athol, although by many who are unacquainted with the facts of the case, and its comparatively recent introduction into North Britain, it is often supposed to be an indigenous tree.

It is said, however, that this popular account of the introduction of the larch into Scotland as respects the particulars mentionel is not a correct one, and that the tree was much in request during the ten years between 1730 and 1740 by many landowners, who planted it to a small extent, most of whom made the same mistake with it that had taken place in England, the trees being inserted in soil too richly cultivated for their future success; and it only began to be planted as a forest tree about the middle of the eighteenth century in Great Britain, its progress, upon the whole, having been far greater and more uniform than that of any other tree not indigenous to the country.

The larch is an elegant object during every stage of its growth, assuming the utmost regularity of form, attaining a symmetrical conical figure, with a straight trunk that acquires massive proportions under the most favourable conditions for its growth ; its branches being commonly horizontal, with a drooping habit. The fuliage is of a bright green, and the leaves grow in the form of bundles, except 
in the case of the young shoots, where they stand out inclividually.

It is now often found in Scotland associated with the Seotch pine, clothing the sides of mountains; its progress as a planted tree having been very rapid and widespread, yielding in many instances massive timber, though in some districts it has proved a comparative failure; but this has urisen in nearly all cases in elevated districts, from the surface soi! having been inainly composed of peat, which is less adapted for the larch than the Scoteh pine.

There are some peculiarities in connection with its growth that are especially noteworthy. No amount of cold or frost can injure it during the winter, when it stands divested of its leaves; but few trees are more susceptible to frosts when clothed with foliage, its leaves, which are remarkably fine and tender, being almost the first to be affected by any sudden change in weather. This is particularly noticeable upon the warm slopes of hill-sides which have a southern exposure. The sumbeans, which not unfrequently fling their radiance mpon the trees towards the end of March, or beginning of $\Lambda_{\text {pril, stimulate the putting }}$ forth of leaf, which succecding frosts injure, or destroy; for sonetimes they will not get over such a visitation, and when they do, it is always only after a considerable interval that they will recover.

From this cause, no little disappointment has often been occasioned by the planting of larch-trees in such situations, which has arisen from a want of duc 
knowledge of its habit, and in any situations where it is likely to be brought into early leaf, other trees should always be planted with it which afford a certain amount of protection. As well, also, for the sake of appearance, this will be found good practice, for on account of its deciduous habit it wears a bare aspect throughout a great portion of the year, which the evergreen Scotch pine, when associated with it, neutralises, the latter also growing well with it; but it answers better, perhaps, when grown with the oak, which draws its support and nourishment from a long distance down in the earth.

In exposed situations in North Britain, where the Scotch pine and larch are planted together, it is generally customary to allot 4,000 plants to an acre, from a quarter to half of that number being larch; but in lower positions 3,000 is commonly thought sufficient, the number being regulated by the suitableness of the soil, and the value of the thinnings to the planter, who can intersperse them in the manner he considers will best answer his purpose.

The larch is a valuable tree for extirpating furze and rank herbage; and even in those cases where other trees are desired to stand permanently, the larch can be made use of very effectually as a pioneer for other descriptions of timber, by interspersing them closely, even if they have to be cut down afterwards, when they have performed the allotted task assigned to them, the confinement obtained by their presence suppressing the native cover, being of quicker growth 
when young, than any other coniferous tree; when planted closely about a yard apart, soon overtopping and suffocating the furze; and for this purpose twoyear-old transplanted plants are used, which are inserted immediately after the furze is cut down.

At the same time it must be remarked that, no plantations have suffered so greatly as larch plantations from want of space at that precise period when it attains the size of a timber tree, rising from ten to twenty years of age. The leaves, being very minute, present only a small surface to the influence of the atmosphere, from whence a great portion of its sustenance must be derived, especially when planted upon flat districts, or level formations; so that when too much crowded, the leaves are unable to elaborate the sap necessary for the production of timber. The trees, under such conditions, become bark-bound, bare, and stunted; and here it becomes essential to draw the necessary distinction, for the thick planting, which is so highly useful during the career of the young tree, arising from the close contiguity of the branches and foliage to the surface of the soil, destroys the native herbage, and converts the decaying matter into a manure for the subsequent growth of the timber tree, which is evidenced by the rapid growth of a plantation after it has suppressed the virginal surface vegetation, and has been properly thinned.

The larch, when planted upon a congenial soil, and in the most appropriate situation for its growth, 
; when

topping

se twoare in-

hat, no plantawhen ten to ninute, nce of 1 of its blanted $t$ when borate The bound, tial to inting, of the of the il, deaying vth of rapid d the perly soil, owth, has been found to produce a greater quantity of timber than almost any other tree; and perhaps, from the want of judicious thinning, none has ever suffered so much from overcrowding, as it requires sufficient space in proportion to its growth. By a wise regulation of nature, the leaves of a healthy young plant are first developed near to the surface of the ground, and some time before the upper ones are exposed to the influence of the biting winds which often prevail in the early spring, so that the top does not get developed until its safety is more assured.

There are some very fine specimens of the larch to be seen growing in Aberdeenshire, near the wellknown mansions of Monymusk, Westhill, Tillyfour, and other places, some of which stand eighty feet in leight; splendid specimens of both larch and Scotch pine being seen in the neighbourhood of the mountain streams which find their way to the Don. There are also some fine specimens to be seen at Ballindalloch Castle, on the banks of the Spey.

Durability of Larch Timber.-From the inquiries that have been instituted upon the subject, it does not appear that the quality of larch timber depends so much upon the maturity of the tree, and the slowness of its growth, as is so decidedly the case in the instance of the Scotch pine; boats that have been built of larch timber forty years of age having been found to last more than double the time than when built of the best Norway pine, and it appears to be most durable in those instances where it is exposed 
definitely to either earth, air, or water; the preservation of some of the best paintings by the Italia n masters, it is said, being attributable to the panels of larch on which they were designed, and many houses in Venice, which have been mainly constructed of larch, show no symptoms of decay, there being single beams, in some of the public buildings and palaces of Venice, that measure 120 feet long.

It is particularly.useful as agricultural timber in the form of posts, or railings when inserted into the ground, or for railway sleepers and similar uses. It is also well adapted, as before said, for certain building uses, as rafters, lintels, joists, and main timber's, though, on account of its propensity to warp, and the greater difficulty in working it, it is not usually employed for flooring boards, or similar lighter purposes, but has been found of great service in shipbuilding.

The bark has been occasionally used for tanning; but as it is twice the bulk of that of the oak, in proportion to its weight, it is seldom profitably manufactured, generally selling at half the price of oak-bark. The larch produces Venice turpentine, taking its name from the fact of having been first exportel from thence, the method of procuring the turpentine being to pierce a full-grown tree with an augur to its centre, the turpentine exuding through the puncture, and conducted by a tube into a trough, where it is received in such pure condition as to need no other preparation to cause it to be suitable for commercial 
purposes than straining through a coarse hair-cloth. It is said that a healthy tree, thus tapped, will flow from May to September, and yield seven, to eight pounds of turpentine annually for forty, or fifty years. The larch is found to flourish and do well upon soils of very opposite qualities, including dry and sandy, as well as that which is wet and clayey; but in the latter case it is absolutely necessary that the land be drained, or the water pass off freely. Where it remains stagnant, or becomes confined in a ierruginous gravel, which is sometimes the case, it then gets stunted and diseased, requiring above all things a free circulation of air, and sufficient space for the full development of its foliage, preferring cool, elevated situations, such as it obtains on the Alps and the Apennines, where it is found luxuriating at a great altitude.

Cultivation.-The larch blossoms and the cones ripen in the same year, and in the beginning of winter, when the cones are collected, it is of importance that the seed is taken from cones that have come off healthy and free-growing trees; the method of extracting it safely, and speedily, being to place the cones on a timber-kiln before described, and spread six inches deep, the temperature not to exceed $110^{\circ}$. When the cones are made brittle by this drying process, they should be taken from the kiln while warm, and laid about six inches deep upon a suitable flooring for the purpose, and threshed to pieces with a flail ; the dust and seed being gathered together as it 
accumulates, which renders the cleansing process easier; and this is a better method of extracting the seed than by means of a mill, as the dust and pieces of cone protect the seeds from injury. After the seeds are threshed out, they should be dressed in a common barn fanner, after which they will be ready to be sown.

In the more southern districts of England, about the middle of April is a favourable time for planting the seed, but in the more northern parts of the kingdom, the end of that month is early enough.

The ground should be well pulverised, and the seed-beds should be formed upon soil that has been well manured the season previous; but if not sufficiently rich for the purpose, and more manure is necessary, well rotted dung should be used. The beds should be formed four feet in width, and smoothly raked, and the seeds covered with quarter of an inch depth of soil. One pound of seed is about a sufficient quantity for four lineal yards, and it should be well protected from the ravages of birds, until the plants have been a fortnight above ground, generally making their appearance in about a fortnight, or three weeks after the seed has been sown. Choice should be made of land that is free from the presence of the grub worm, which is often destructive to larch ; and the beds should be carefully weeded during the season, the young plants finishing their first year's growth by the end of September, when they will be from four to seven inches high. 
process

cting the al pieces fter the sed in a e ready 1, about planting he king-

and the as been ot suffie is nehe beds nootlily in inch ifficient be well plants naking weeks ild be of the ; and e seayear's ill be
If the plants have come up thickly, they should be thinned out during the ensuing winter, or spring, the ground being carefully loosened with a fork, and those taken up planted in nursery lines, in beds made for their reception, standing in the rows fifteen inches apart, and the plants a few inches asunder. So disposed of, both lots when they have thus stood for another year, being fit to be planted out in moorland, the undisturbed ones becoming two-year-old seedlings, and those transplanted, one-year-old transplanted plants. Larch plants should never be allowed to stand in the seed-bed longer than two years undisturbed. When strong plants are wanted to extirpate furze, or suppress any description of rank herbage, they should be allowed to stand for two years in nursery lines, where they will have commonly attained a height of from two to two-and-a-half feet, and be of an adequate strength for the toughest description of forest ground. The two-year-old seedlings, after being transplanted into nursery lines for two years, will generally be three feet ligh; but beyond this age and size, the tree does not appear to be adapted for successful removal ; and, although a deciduous plant, no other seems so capable of effectually subduing any coarse, rough herbage which it may be thought necessary to extirpate; and by the aid of larch-trees unprofitable land may be made to become ultimately of a good, serviceable description, from the constant dropping of the leaves, and the gradual formation of a regetable surface. 
When planted in situations the most favourable to their growth, larch-trees will often attain an altitude of forty feet in twenty years, though a height of thirty feet is the more common average.

Casualties and Diseases. - The rot, atmospheric blight, and other casualties and diseases, sometimes visit the larch; an insect called Coccus Laricis. having at times been very destructive in larch plantations, being rarely met with upon strong trees of vigorous growth, but chiefly infesting confined woods and low situations, where humidity of atmosphere prevails to a great extent, being most destructive in wet seasons, its ravages being very fatal in periods when late frosts occur in spring; and in wet and cloudy seasons; as before said, the tree requiring a clear, cool atmosphere. Those which have been visited to a great extent by this insect never advance in growth, the sap appearing to escape through numerous perforations, and the tree acquires a kind of black coating, which in some degree resembles the effect of smoke, the top shoots of such affected trees being invariably short and feeble.

But when there is free circulation of air, and the trees. stand well apart, and in those plantations not exclusively composed of larch, the coccus is least injurious.

About the end of July, or beginning of August, an atmospheric blight has at times visiter larch plantations with great severity, blasting thr foliage, and giving it a ripened appearance, mustly affecting the 
rable to altitude ight of spheric netimes Laricis plantarees of woods sphere tive in periods et and ring a been lvance rough kind les the trees

ad the as not least

st, an

lanta-

and othe oldest leaves, and only slightly touching the more recently expanded ones, except in very pronounced cases, its effects often being wrongly attributed to frost.

The rot in the larch is a disease which appears to originate in the root, and work its way upwards, causing the trunk to become hollow, but is not always confined to the trunk, and has been observed to prevail most on those sites which have been previously occupied by timber, it being surmised that the decaying roots, and the fungus which forms where timber has been felled, tend to injure the roots of the growing trees; even manure being found to be injurious to the larch ; but a wet subsoil is doubtless the frequent occasion of rot in the larch, which to a certain extent must be ranked with the class of English trees as elms and poplars, which have a natural tendency to get diseased in the trunk, and in those situations which cannot be considered as favourable ones for the growth of the larch, other kinds of trees should be chosen in preference.

Canker visits it also when grown in wet situations, and it has been noticed to be prevalent when planted after corn. Portions of the tree decay, and a black substance issues from the affected part, its whole growth becoming distu:' being apparently no method of treatment that will effect a cure; all that can be done being to avoid planting the tree under unfavourable conditions, such as allowing larch to follow after scotch pine, when it 


\section{1:38 EXGLISI TREES ANU TRER-PLANTING.}

ahmost invariably becomes unsound; in all probability, as before stated, owing to the read roots coming into contact with the living ones, and so communicating the principle of decay through means of infection from the fungoid growth of the old Scotch pine roots, and though larch is often planted after that tree, the practice is undoubtedly a bad one.

The Cedar (Cedrus libani, or Abies Cedrus).-The cedar of Lebanon, though commonly met with in England as an ornamental tree, and attaining a very large size in this country, has unfortunately never been planted in any great numbers as a timber tree, the comparative slowness of its growth being a good deal against it, though at Lord Carnarvon's, at Highclere, they have been grown with remarkable rapidity, and the cedars which were planted in the Royal Garden at Chelsea, in 1683, in two cases had in eighty-three years acquired at two feet from the ground a circumference of more than twelve feet, their branches extending over a circumference of about 120 feet.

A cedar-tree planted by Dr. Uvedale, in the garden of the Manor-house at Enfield, about the middle of the seventeenth century, is recorded to have hod a girth of fourteen feet in 1789 , about eight feet of the top having been blown off during a hurricane which visited the district in 1703; while at Whitton, near Hounslow, a very fine specimen was blown down in 1779. Its height was seventy feet, the branches covering an area of 100 feet in diameter, the trunk 
proba-

d roots

so com-

means

Scotch

ed after

ne.

). The

vith in

a very

never

1 tree, eing a on's, at irkable

in the

es had

$m$ the

e feet,

about

e gar-

nicldle

e hod

eet of

icane

itton,

down

nches

runk being sixteen feet in circunference at a height of seven feet from the ground, there being about ten principal branches whose average circumference was tweive feet. There seems to have been a great deal of obscurity as to the date when this tree was planted, some historians attributing it to the reign of Elizabeth, and indeed by her own hand, the common assumption of the introduction of the cedar into Engiand being that, it took place about the middle of the seventeenth century.

There are many large trees of very considerable dimensions to be met with in various parts of the kingdom, one at Hillingdon, near Uxbridge, when at the supposed age of 116 years metsuring 53 feet in height, the spread of its branches being 96 feet from east to west, and 89 from north to south, the circumference of the trunk close to the ground being $13 \frac{1}{2}$ feet, and at 7 feet from the ground $12 \frac{1}{2}$ feet, and at 13 feet, just under the spread of the branches, it was 15 feet 8 inches. Two trees used to stand, if not standing now, at Claremont, and Strathfieldsaye, respectively, the former 100 feet high, with a trunk 5 feet 6 inches in cliameter, and the latter with a bole 108 feet in height, and a head 74 feet in diameter; while at Sion House one measured at the same time 72 feet in height, with a trunk 8 feet in diameter at a yard from the ground, the head being 117 feet in diameter.

The growth of two cedar trees planted with others at Hopeton House, near Elinburgh, in 1748, were 

chronicled as follows in the different epochs speci-
fied :-

The first cedar measured in circumference in $1801 \quad$ Ft. in. 100
The second The $\cdot{ }^{\cdot} \cdot{ }^{\circ} \cdot 86$ The increase of each being as follows :-

\begin{tabular}{|c|c|c|c|c|c|}
\hline & & In 1820 & 1825 & 1833 & 1848 \\
\hline $\begin{array}{l}\text { First cedar } \\
\text { Second cedar }\end{array}$ & $\cdot \quad \cdot$ & $\begin{array}{cc}\mathrm{ft} . & \text { in. } \\
13 & 1 \frac{1}{2} \\
10 & 9 \frac{1}{2}\end{array}$ & $\begin{array}{cc}\text { ft. } & \text { in. } \\
14 & 0 \\
11 & 4\end{array}$ & $\begin{array}{cc}\text { ft. } & \text { in. } \\
15 & 1 \\
12 & 3\end{array}$ & $\begin{array}{ll}\text { ft. } & \text { in. } \\
17 & 8 \frac{1}{2} \\
14 & 2\end{array}$ \\
\hline
\end{tabular}

The cedar is indigenous to Mount Lebanon in Syria, and to Mount Atlas in the north of Africa, and a few analagous districts, but is found in much smaller numbers than formerly was the case, the example of Solomon'? four score thousand hewers having been imitated to a considerable extent by other hewers of a later generation, the number of men employed in the procuring of timber for the temple giving a good idea of what must have been the extent of the original cedar forest of Lebanon.

It is certainly the most imposing and magnificent tree of the coniferæ, assuming a grand and picturesque form. The durability of its timber has been a matter of notoriety for ages, the ships of Sesostris, the Egyptian conqueror, having been described by ancient writers as being made of cedar timber, one of them being 280 cubits long; and a difficulty has occurred with some modern writers as to the exact identification of the cedar in some of the instances recorded, there being other trees, such 
s speci-

Ft. in.

100

86

1848

t. in.

$78 \frac{1}{2}$

42

Syria,

a few

maller

ample

been

ers of

loyed

ing a

of the

ficent

pic-

has

os of

de-

cedar

nd a

rs as

of

such

as the white cedar, or cypress, and the red, which is juniper, grown in this country. The timber is soft, and anything but durable; but, as mentioned before, the manner of its growth is so entirely different to those raised in its native habitat, that the wood has become vastly deteriorated, the tree requiring to be, at its best, in a somewhat peculiar and special situation, such an one as that of Mount Lebanon, where the heats of summer melt the snows annually, which have a peculiar influence upon the growth of cedars placed at a high altitude, in a clear and bracing atmosphere, and which produced the timber of biblical times; the degencrate trees which are raised in Britain in the same way, described as being the case with the Scotch pine, having become greatly deteriorated in point of hardness, and durability, from their original state. When allowed sufficient space, the tree is more remarkable for the size of its trunk, and the remarkable expansion of its branches, than for its height; its appearance impressing the beholder with a vague sense of its comparative immortality, there being a firmuess, and stability of the trunk, and the manner in which it lays hold of the ground, that heightens this impression.

The description given by the prophet Ezekielwho was a close observer of natural objects_of the cedar of Lebanon is very correct. 'Behold, the Assyrian was a cedar in Lebanon with fair branches, and of an high stature; and his top was among the thick boughs. His boughs were multiplied, and his 
branches became long. The fir trees were not like his boughs, and the chesnut trees were not like his branches; nor any tree in the garden of God was like unto him in his beauty'-the cedar of Lebanon being often used by the Hebrew prophets as a type to illustrate the steadfastness and spiritual condition of the righteous, its elegance and grandeur being often extolled by them.

The celebrated cedars of Lebanon have now nearly all disappeared, and there are now, doubtless, more cedar-trees to be found in England than are contained in the whole of Syria at the present time.

An Arabian poet describes Lebanon as bearing winter on its head, spring upon his shoulders, and autumn in his bosom, while summer lies sleeping at his feet; and it is at the bottoms of the highest peaks of the mountain that the cedars were found-a situation, doubtless, from concomitant circumstances more than usually favourable for the growth of the trees, which were doubtless sustained by the melting snows at the hottest season of the year, by which their power and vitality must have been greatly augmented; and as the nature of the tree wonld remain the same, a similar position would be necessary to secure an equally favourable development as regards durability and quality of timber-essentials somewhat difficult of attaimment.

The cedar is said sometimes not to yield cones before it reaches the age of 100 years, there seldom being any produced before it has attained forty years, and it is not till severa! successive crops of cones 
like his ranches; o him in used by ce steadeous, its them. ve now ubtless, lan are time. bearing ss, and ping at peaks situamore trees, snows their ented ; same, re an bility fficult

cones ldom rears, cones

have been produced that the vitality of the seeds can be depended upon. When ripe, the cones do not discharge their seeds, nor drop from the tree like other species of conifera, but hang on for many years, when the scales give way, and the seeds are shed, leaving the axis of the cone attached to the tree; it being a matter of some difficulty to extract the seeds from the cones, which are usually steeped in water for a few days, or buried in the ground to make them soften, after which the bottoms of the cones are cut off, and a hole bored in the axis, which is split up.

Cultivation.-When the beds have been prepared in the usual manner for the reception of seed, and raked fine, it should be sown in the month of April, and placed about an inch apart, being covered witl half an inch depth of soil. In about six weeks after sowing, the young plants will make their appearance above ground, thick sowing at the space of an inch assisting them collectively in breaking simultaneonsly from the ground, when planted at greater distance the surface of the soil being apt to cake, and become hard, so that only the strongest cotyledons could force their way through separately.

Nurserymen sometimes sow the seed in heat under glass, and pot the young plants off when the cotyledons are only full grown, while others set them in pots when the plants are a year old, and change them into larger ones with their advancing growth. But all this pain is not necessary, and they may be raised 


\section{ENGLISH TREES AND TREE-PLANTING.}

in the same way as those of the Scotch pine and larch, when they are wanted in quantities; and, without doubt, in many situations favourable to their growth, in accordance with the conditions described as necessary. Cedars might be profitably planted to a much more considerable extent than most Englisl planters now commonly think of doing.

The seedling plants should be transplanted into nursery lines at one or two years of age, where they should be allowed to stand for two or three years, and then be permanently planted out in those situations where they are intended to remain. If allowed to stand longer than this, the roots strike out, and become destitute of that bushy quality which is so essential for establishing this order of trees in their ultimate situations-a point that is never lost sight of by the experienced planter of coniferous trees.

The Indian Cedar (C. Deodara).-This tree was introduced into Britain from the Himalayas in 1822, and is the same tree described by Bishop Heber as being accounted sacred by the Hindoos, and generally met with in the neighbourhood of their ancient temples, being found in Nepaul, Cashmere, Kamaon, and other places, mostly at elevations varying from 7,000 to 12,000 feet above the sea level, when it attains the height of 150 feet.

It was found to be perfectly liardy, and many fine specimens of the tree are now to be seen growing in Great Britain. The cones are similar in size and shape to those of the cedar of Lebanon, and are im- 
pine and ind, withto their described lanted to English

ted into ere they years, se situaallowed out, and ch is so in their st sight rees.

ree was in 1822 , eber as enerally ancient Camaon, from vhen it

many rowing ize and are im- ported into this country. Sufficient time has scarcely elapsed for their growth in this country to have become a common event as yet.

Cultivation. - The seed should be sown in beds, and treated in the same way as those of the cedar of Lebanon; but they lose their vitality if kept too long, and need to be sown within seven or eight months. The tree, however, can be propagated by cuttings, and grafting on the larch, which is a quicker method of raising trees than from seed, though the latter is preferable. It grows more freely than the cedar of Lebanon, with pendulous spray of a graceful form, and makes a handsome tree for a lawn, or dotted about a park-like meadow, requiring ample space and congenial soil to appear at its best, when it will rise with a grandeur, and magnificence that no other tree can surpass.

Its timber emits an agreeable perfume, being compact and resinous, and capable of taking a high polish, but its comparatively recent introduction into this country has not allowed that of native growth to become familiar to English carpenters; but its nature appears to approximate very closely to the description given of the ancient cedars of Lebanon as to durability in India, having been found there in the roofs of Hindoo temples that were fully 200 years old, in a perfectly sound condition. 


\section{CHAPTER VII. \\ CONIFEROUS TRELS (contimed).}

THE YEW-YEW-BOWS-PROISSART'B ACCOUNT OF THE ENGLISH ARCHFRS -ANCIENT YEW-TREES-PANTASTIC SHAPES-CULTIVATION OF THF YEW-TEEE-POISONOUS NATURE OF TH YSW-SPRAY-THK IRISH YEW -THE CYPRESS-ANCIENT CYPRUSS-TREF-DURABILITY OF CYPRES TIMBER-CULTIVATION OF TEN CYPRESS-TREE-THE WIITE CEDAR.

The Yew (Taxus baccata). Of the genus Taxus diocia monadelphia of Linnæus; is a tree celebrated in the military, and also in what may be termed the religious-superstitious, history of England, the yew being consecrated and held sacred; at one time being very plentiful in England and Ireland, and probably also in Scotland, a good deal of it being found in Ireland embedded in the soil.

Before the introduction of fire-arms, the wood of the yew was in so much request for bows, that a law was enacted in Venice that every ship trading to the port should bring ten bow-staves with every butt of Malmsey wine.

Englishnen used to be celebrated for the use of the bow, with 'which every man was expected to be familiar, it being enacted by statute made in the fifth year of Edward IV., by which every Englishman and every Irishman dwelling with Englishmen, was directed to have a bow of his own height, made either 
of yew, wych-hazel, ash, or awlune (laburnum). A great quantity of the wood of the yew was thus - consumed at one period by the bow-makers, or fletchers, of England ; much in the same manner that during more recent wars, a great many walnut-trees were felled to make musket stocks of the 'old Brown Bess.'

The genus may be divided into two distinct species, the common, or English yew, and the upright, or Irish yew, each having given rise to a few varieties; the common yew (Taxus baccata) bearing blossoms that are unisexull, the sexes being generally placed on distinct plants, though instances sometimes occur of a tree yielding both male and female flowers.

In its wild state it is mostly found standing solitarily, being partial to a north, or shaded locality, succeeding best in a cool, and moist soil, and thus differing very materially from the Scotch pine, and similar trees, and it a: swers when planted amongst tall deciduous trees, on this account being very valuable as underwood in forming shelter, and seclusion, where it is desired; most trees under such circul stances being apt to become feeble, and give only a scanty supply of foliage.

The yew is remarkable for its slow growth, fiveyear-old plants nat have been one year transplanted not averaging more than a foot in height, and at the age of ten years, when reared in nurserics upon the plan usually followed, being scldom more than a yard high. As a counterbalance to this defect, it will, 
however, bear removal at a comparatively large size, from the nature of its naturally fibrous roots.

Yew Bows.-To readers of English history the . yew, on account of its association with the long bow, is very interesting, the conquest of Ireland, by Henry II., in 1172 , being mainly attributed to the skill of the English archers, the way in which they handled their bows being the proud distinction of the English yeoman, their boast being that, none but an Englishman could bend that powerful weapon, the yew bow ; but it seems there was a peculiar knack, or art, in its use, for our archers did not exert all their muscular strength in drawing the string with the right hand, but pushed forward the whole weight of the body into the horns of the bow, with the left.

Froissart's Account of the English Archer..-Chaucer in his quaint style is eloquent upon the mighty bowe, and the cloth-yard shaft carried by his archer, the arrows at that period being cast in showers from this effective engine of ancient warfare, the bowmen being chiefly relied upon by the English leaders, in their sanguinary battles which were the result of our claims for the succession of the crown of France, of which many old poets, and chroniclers, especially Froissart, give a very graphic account.

In Froissart's narrative of the battle of Blanchetagne, or passage of the Somme, which took place just before that of Crecy, he says :- 'The Frenchmen defended so well the passage at the issuing out of the water, that the English had much to do. The Genoese 


\section{FROISSART'S ACCOUNT UF THE ENGLISH ARCHERS. 149}

arge size,

story the

ong bow,

oy Henry

e skill of handled e English Englishew bow ; $r$ art, in eir musthe right $t$ of the t.

Chaucer ity bowe, her, the rom this en being in their of our ance, of pecially

Blanche$\mathrm{k}$ place nehmen $t$ of the Genoese did them great trouble with their cross-bows. On the other side the archers of England shot so wholly together, that the Frenclimen were fain to give place to the Englishmen.'

And in his account of Crecy he continues:'There were of the Genoese cross-bowes about a fifteen thousand, but they were so weary of going a-foot that day, a six leagues, armed with their crossbowes, that they said to their constables :- "We be not well ordered to fight this day, for we be not in the case to do any great deed of armes; we have more need of rest," which being reported to the Count d'Alençon, he said, "A man is well at ease to be charged with sucl a sort of rascals, to be faint and fail now at most need."' Just at this time a violent storm is described as happening, and upon its cessation the narrative proceeds:- 'When the Genoese were assembled together and began to approach, they made a great leap and cry, to abash the Englishmen, but they stood still, and stirred not for all that. Then the Genoese again the second time made another leap and a full cry, and stepped forward a little, but the Englishmen removed not one foot. Thirdly again they leaped and cried, and went forth till they came within shot. They then shot fiercely with their crossbowes. Then the English archers stepped forth one pace, and let fly their arrows so wholly and so thick that it seemed snow. When the Genoese felt the arrows piercing through heads, arms, and breasts, many of them cast down their cross-bowes and did cut 
their strings, and return discomfited. When the French king saw them fly away he said, "Slay these rascals, for they shall lett and trouble us without reason." Then ye should have seen the men of arms dash in among them, and killed a great number of them, and ever still the Englishmen shot where as they saw thickest press. The sharp arrovs ran into the men of arms and into their horses, and many fell, horses and men, in the midst of the Genoese, and when they were down they could not relieve again; the press was so thick that one overthrew anotlier.'

Although we may now possibly blush for the unjust wars carried on by us for the succession to the crown of France, now the long feud which had existed for so many centuries between Frenchmen and Englishmen has died out, and we can appreciate one another's good qualities, and especially the peaceloving disposition of the thrifty French peasants, who were mainly the victims in these fierce encounters, yet we cannot help being proud of the bravery of our countrymen; and as well as Crecy, Froissart gives a description of the prowess of the English archers at Poitiers:- Then the battle began on all parts, and the battles of the marshals of France approached, and they set forth that were appointed to break the array of the archers. They entered ahorseback into the way where the great bedges were on both sidus, set full of archers. As soon as the men of arms entered, the archers began to shoot on 
hen the ay these without of arms mber of here as can into d many renoese, relieve erthrew

the unto the h had chmen reciate peace$\mathrm{s}$, who unters, of our ives a rchers parts, e apted to ed awere s the ot on both sides, and did slay and hurt horses and knights, so that the horses, when they felt the sharp arrows, they would in no wise go forward, but drew a-back, and flung, and took on so fiercely that many of them fell on their masters, so that for press they could not rise again, insomuch that the marshals' battle could never come at the prince.' And, remarks the author further :- 'True to say, the archers did their company that day great advantage, for they shot so thick that the Frenchmen wist not on what side to take heed.'

The English bow, indeed, appears to have been a very effective weapon when used against the mounted steel-clad knights of the European kingdoms of the middle ages, for in various battles the English bowmen distinguished themselves greatly, as at that of Aljabarota in Portugal, which was fought between the Kings of Portugal and Spain, in the early part of Richard the Second's reign, the King of Portugal being assisted by John of Gaunt, with an English force, while the King of Spain was aided by volunteers from France and Bearn. At this battle, one of the bloodiest on record, the English archers greatly distinguished themselves, by their exertions contributing greatly to win the battle, from the almost total impossibility of bringing the horses that carried the men-at-arms to face the cloud of arrows which was discharged against them. This encounter is thus described by Froissart.

- The same Saturday was a fair day, and the sun was turned towards evensong. Then the first battle 
came before Aljabarota, when the King of Portugal and his men were ready to receive them. Of these French knights there were a two thousand spears, as fresh and well ordered men as could be devised; and as soon as they saw their enemies, they joined together like men of war, and approached in good order till they came within a bow-shot; and at their first coming there was a hard rencounter, for such as desired to assail, to win grace and praise, entered into the strait way, where the Englishmen by their policy had fortified thein' (apparently a common mancuvre of our countrymen in those days). 'And because the entry was so narrow, there was great press, and great mischief to the assailants; for such English archers as were there, shot so wholly together, that their arrows pierced men and horses, and when the horses were full of arrows they fell upon one another. . . . There were many of the lords and knights of France and Bearn taken and slain, and all their companies that were entered within the strait. Their horses were so hurt with the archers that, they fell on their masters and upon one another. There these Frenchmen were in great danger, for they could not help one another, for they had no room to enlarge themselves, or to fight at the will.'

Long after the introduction of fire-arms, in the fourteenth century, the bow continued to be the principal weapon of defence, being used both at Agincourt, and Flodden Field.

Ancient Yew-trees.-The yew has attained great 
TG.

f Portugal Of these spears, as vised ; and ed together order till irst coming desired to the strait oolicy had uvre of our the entry great misarchers as cir arrows orses were . . There rance and banies that ses were so eir masters hmen were e another, , or to fight ms, in the to be the d both at ined great 


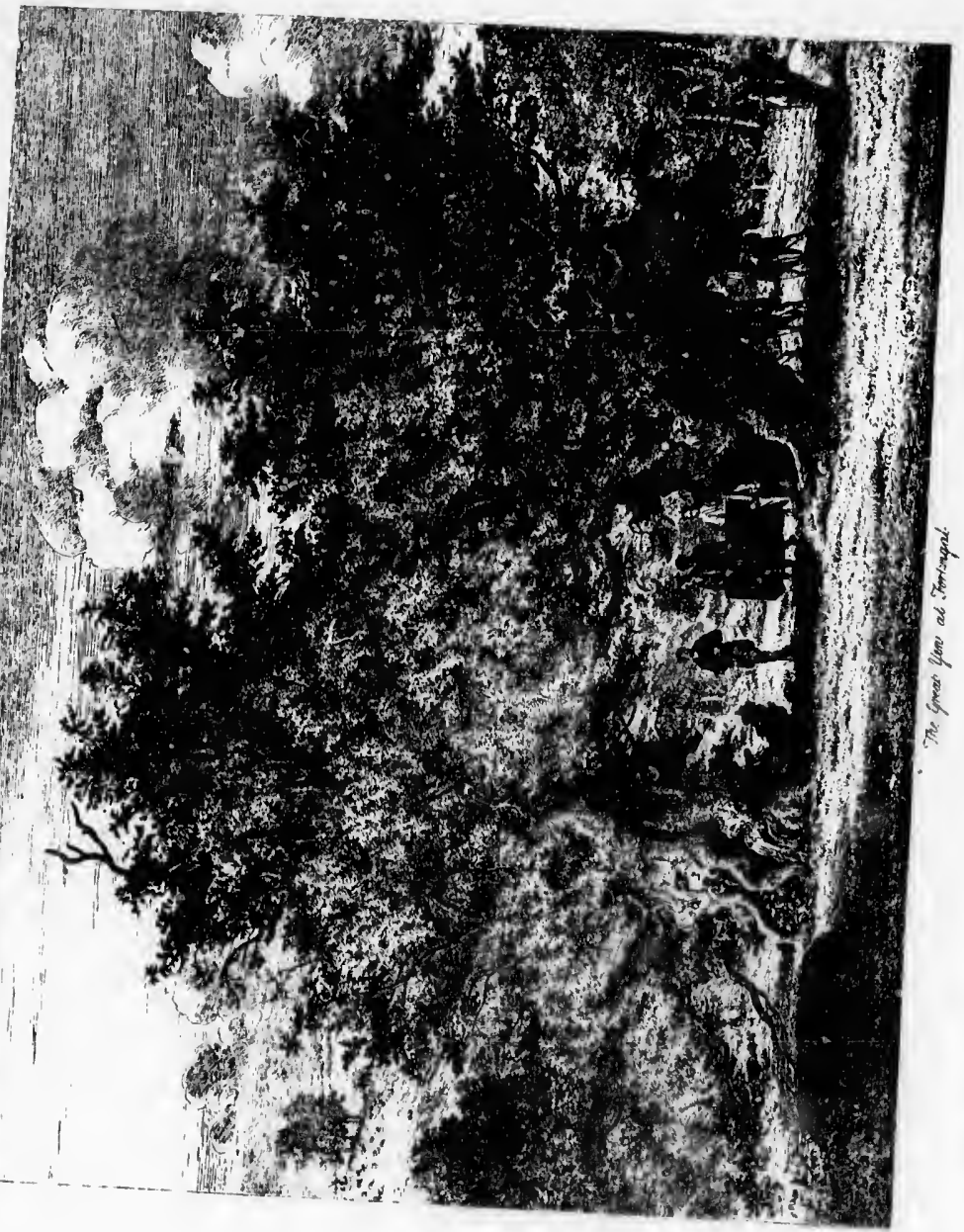


age and dimensions, in each of the three kingdoms, and it is a matter of regret with lovers of ancieni trees, these old relics of the past are literally crumbling away, without having their places occupied by natural successors, which one would wish to be the case, many interesting particulars being recorded of these venerable trees.

The 'Edinburgh Philosophical Journal ' for 1833 gives a description of the Fortingal yew in Scr'land, which stands in a churchyard, in the vicinity of a small Roman camp, in a remote situation, in a romantic district, at the entrance to Glen Lyon, in Perthshire. 'The side of the trunk now existing gives a diameter of more than fifteen feet, so that it is easy to conceive that the circumference of the trunk, when entire, should have exceeded fifty feet. Happily, further depredations have been prevented by means of an iron rail which now surrounds the sacred spot; ard this venerable tree, which in all probability was a flourishing tree at the commencement of the Christian era, may yet survive for centuries to come.' Pennant also describes the same tree.

The yew-trees which now remain standing in Scotland and Ireland of great age are very few, that at Mucruss Abbey, in the latter, having a trunk about six feet and a half in circumference, being fourteen feet high, terminating in a head that fills the area of the cloisters.

The old yew-tree at Fountains Abbey, in Yorkshire, 
was said to have been an old spreading tree in 1132 , beneath which the monks encamped before the foundation of the abbey. Evelyn describes the Crowhurst yew as being thirty feet in circumference, while that of Braburne Churchyard in Kent was nearly twenty feet in diameter, though it had suffered greatly from storms; and at Sutton, near Winchester, there being, in his own works, 'such another monster.' In the woods at Cliefden there are some remarkable remains of yew-trees, whose roots, apparently of enormous age, twine about the chalk rocks in the most grotesque fashion.

In Wales, great value used to be set upon the yewtree, which is proved by the ancient Welsh laws, the consecrated yew of the priests having got to supplant in value the sacred misletoe of the Druids. The following extract of the ancient Weish laws fixes the value of the different trees. It must be borne in mind that at the age to which wie are referring, fruit-trees -as apple-trees-were comparatively scarce.

A consecrated yew, its value is a pound.

A misletoe branch, threescore pence.

An oak, sixscore pence.

Principal branch of an oak, thirty pence.

A yew-tree (not consecrated), fifteen pence.

A sweet apple, threescore pence.

A sour apple, thirty pence.

A thom-tree, seven pence halfpenny.

Every tree after that, four pence.

Fantastic Shapes.-In funeral processions the branches of the yew were carried over the dead by 
1132 ,

e the Crowwhile early reatly there ister.' kable $\mathrm{y}$ of the

yewthe lant

The the ind rees

he

by

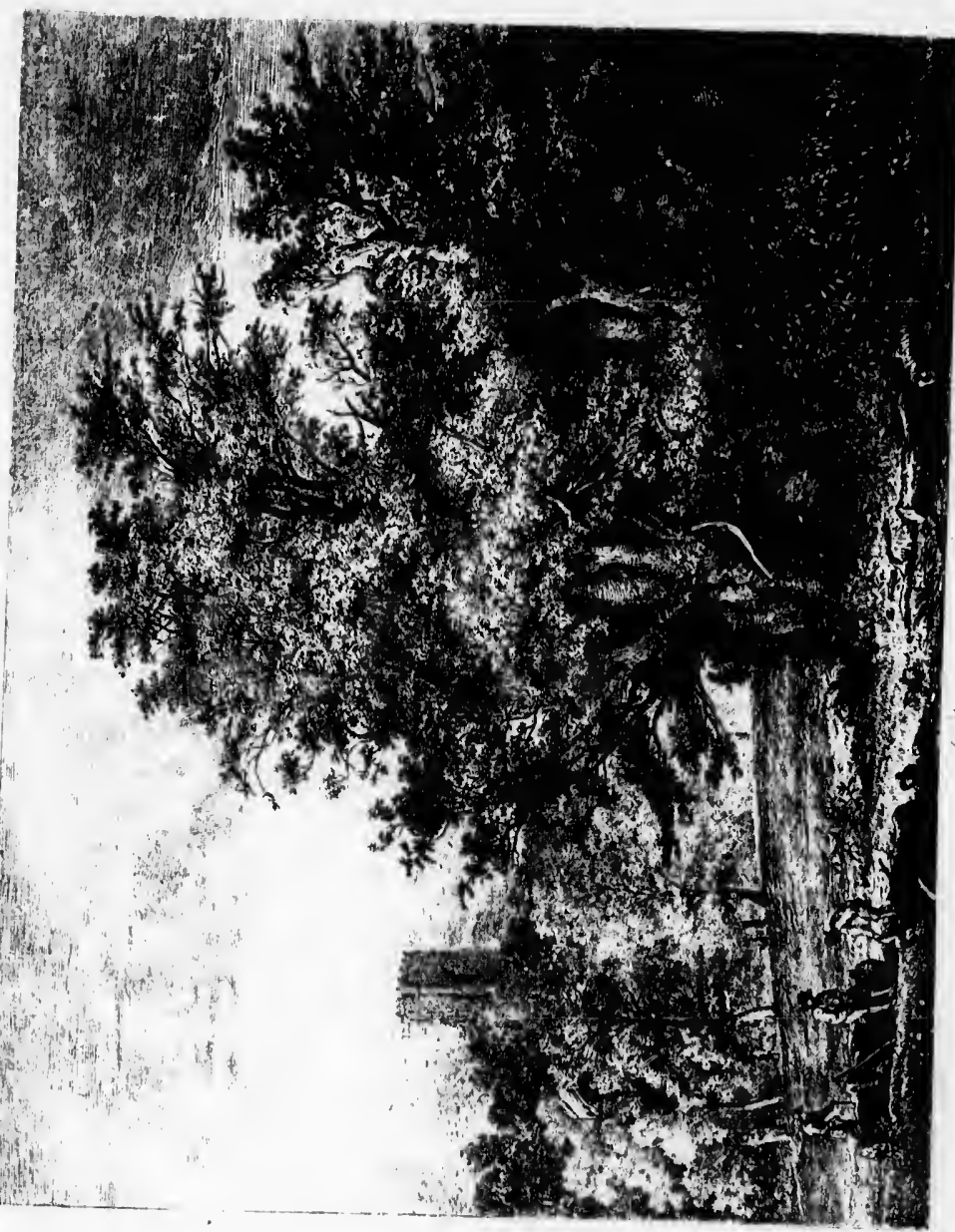




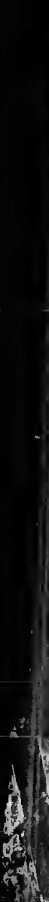

$2 \sqrt{7}$ 
mourners, and thrown beneath the coffin in the grave, and being an evergreen, was considered typical of the immortality of man; and in most old churchyards, one or more yew-trees were to be found, the custom being much practised in the sixteenth and seventeentl centuries, of clipping them into fantastic shapes, especially the effigies of birds and beasts, a practice which was doubtless acquired from the Romans, who, as we find from Pliny's letters, were in the habit of cutting their evergreen trees into these fantastic forms, a custom which Lord Bacon justly deprecates as being out of character, for he says in his essays: ' I, for my part, do not like images cut out in juniper and other garden stuff; they be for children.'

Cultivation.-The berries of the yew become ripe in autumn, when they should be collected and cleared from the pulp in which they are encased, by washing. The stones, or seed, should then be commingled with three times their bulk of sand, and put into a pit for a year, or fourteen months, after which they may be sown either in winter or spring, during open weather. The seed should be sown in a rich, loamy soil, of a description that is not likely to cake, or get hard upon the surface.

The seed should be sown so as to ensure as nearly as possible the plants coming up at a distance of about two inches apart, and covered with soil about half an inch in depth. The crop comes up very irregularly, some coming up the first season after sowing, and the remainder in the spring following 


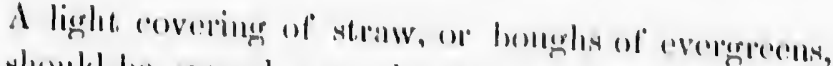

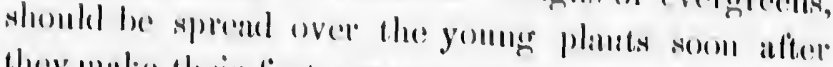

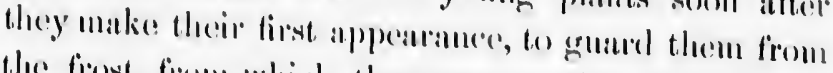
the fiost, fiom whind they are oreasionally likely to sutlier withoute this proterefioms.

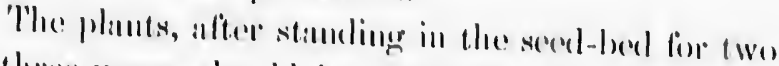

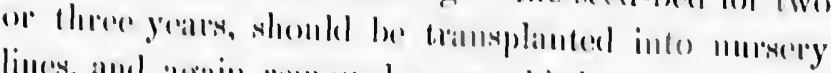

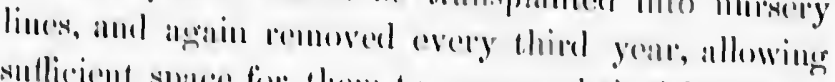

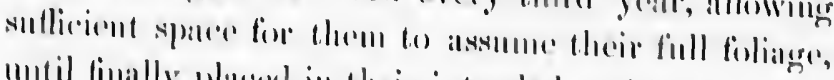

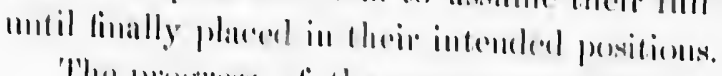

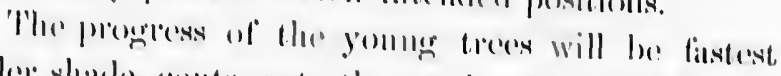

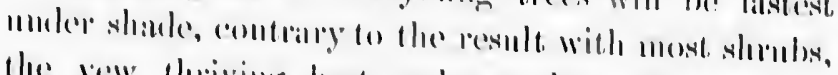
the yew thriving best muler stach comelitions, and

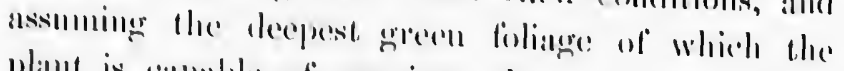

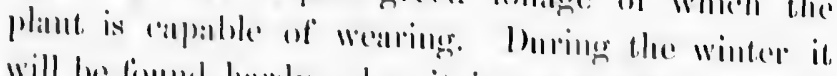

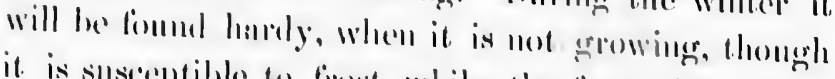
it is susereptible to fiest while the formation of its

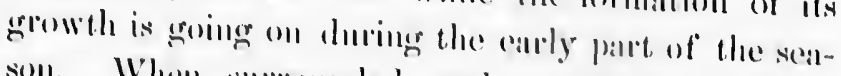

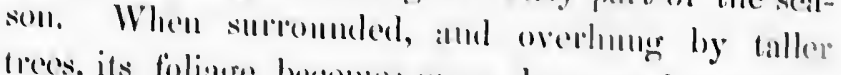

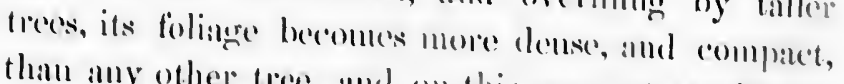
than any other tree, and on this arrount can be all-

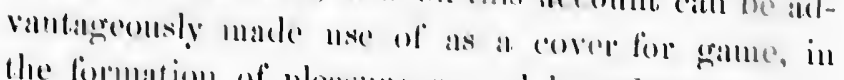
the firmation of pleasume-gromed bomudaties, or for

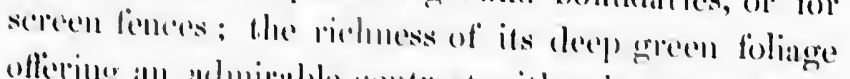
oflering all ahluirible comitlast with other trees, especially during the wiuter season, and when clipped as a hedge, it werows so comparetly that even the smallest birds cammot very readily thed a passigge through it.

As all ormamental tree in a cold (limite, it is a very usefinl one fir the lawn, or pleasure ground: 


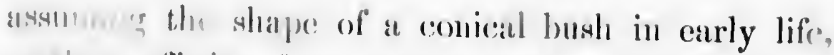

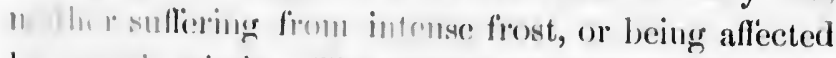
by romigh winds. The therries of the yew-tree are muh rolished by smeri 1 ir 1 hile its dense foliagre

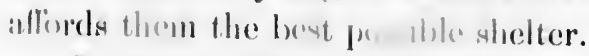

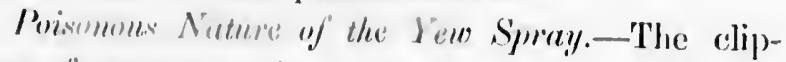
pings of yew es when eaten by cattle, and horses, arre poismoms. Fiequent cases have occured of the yew spray dropping fiom a churchyard into an ardjoining mearlow, when yew-trees have been trimmed, which the cattle have o. 'n with fiatal results. In recent cases, where the chippings of yew-trees have heen thrown upon a rubhish heap accessible to cattle which have partaken of them, and died in consequence, their owners have recovered their value in a conrt of law, thought they were thus disposed of in ignorance of their joisonoms nature. Deer, however, it is said, eat them with impmuity, and according to Linnatus sheep and goats can do the same; and even ases have ocemred where cattle have eaten them without fatal results, but this immunity, it has been considored, has most likely been caused by small, and gradnal benimumgs, and when mixed with other food; being mostly to be feared when taken upon an empty stoma'h. 'The leaves if eaten by mam are fatal, and the berries, if taken in any quantity, are highly injuriwns ; thongh, as well as small birds, laige domestirated poultry, as turkeys and peacocks, can eat both the leaves and berries with perfect impunity.

The trunk and branches of the tree grow very 


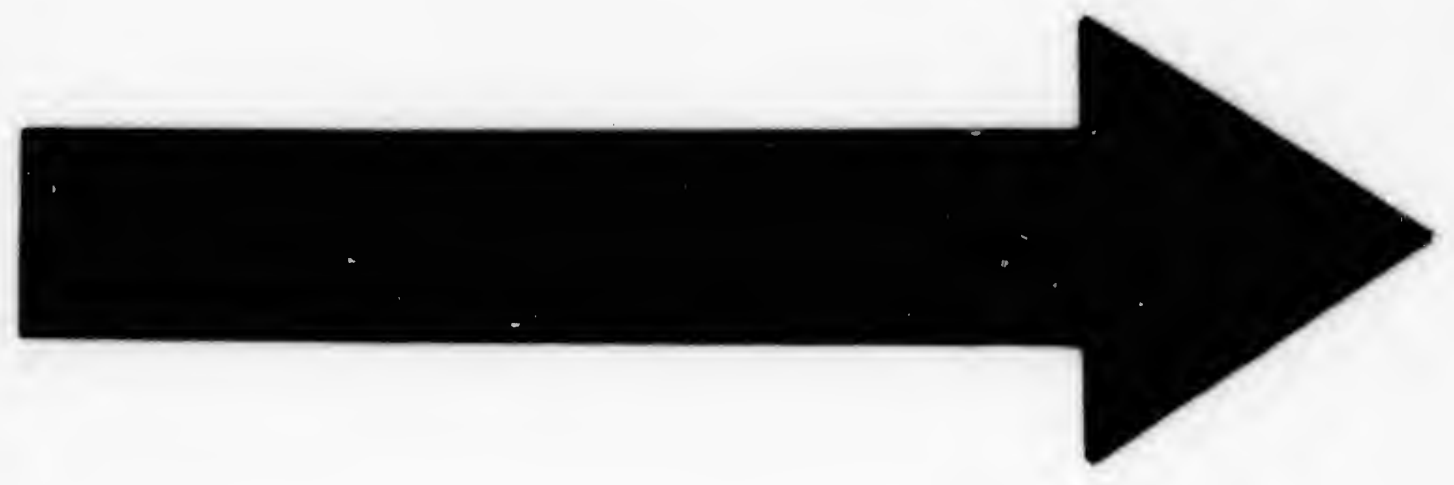




\section{IMAGE EVALUATION TEST TARGEI (MT-3)}
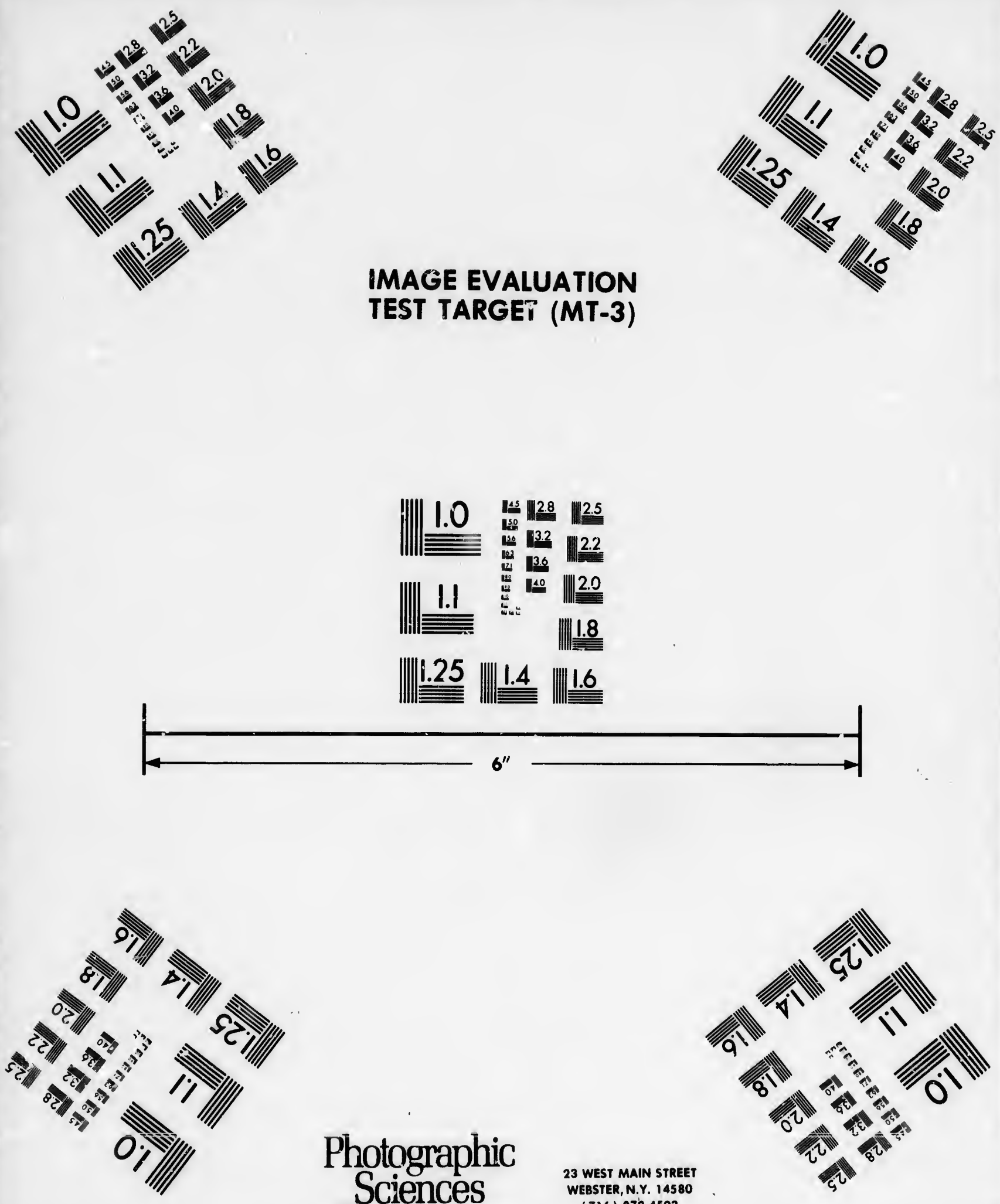

Photographic Sciences Corporation

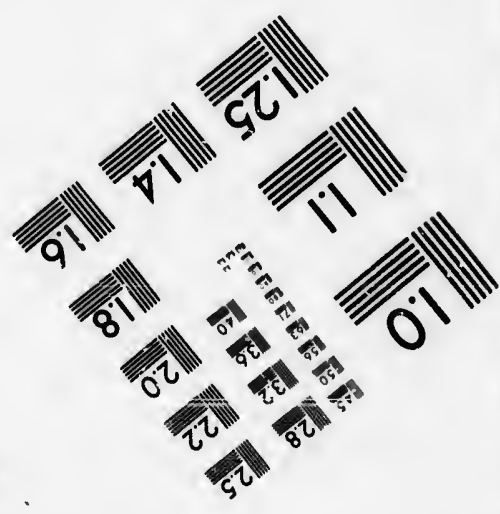


4 s 30 
straight, the bark being cast annually. The wood is hard, extremely durable and compact, being red in colour, veined, and very elastic. From the foregoing instances furnished, it may be surmised that, in its age and growth, an epoch of a century makes no great change in the appearance of a yew-tree of any considerable size.

The Irish Yew (T. fastigiata).-The Irish, or upright yew, partakes more of the nature of an ornamental plant, and does not attain the size of a timber tree, assuming a shrubby habit of growth, from a single stem, at the surface of the ground, sending ou $i$ numerous, tapering branches, of handsome proportions, narrow at the bottom and broad at the top, assuming a reversed shape to that worn by the com. mon species, which causes it to be a very conspicuous, and ornamental object. It is one of the hardest of evergreens, and may be propagated by cuttings, which should be planted in sand, or soil well impregnated with silicia, in the months of August or September. The cuttings should be covered with a hand-glass, and shaded. The foliage of the Irish yew is of the deepest shade of green.

The Cypress (Cupressus sempervirens).--The cypress takes its name from the Island of Cyprus, which has now become an appanage of the British crown, where it is found in abundance, as well as in other islands of the Archipelago of Greece, Turkey, and Asia Minor, being a common tree in the Levant. It was a favourite tree of the Moors, who used to plant it 
round their palaces, and both by the ancient and modern Romans used as an ornamental tree in the neighbourhood of their dwellings ; and notwithstanding its present abundance in Italy, it is said to have been introduced there originally from Greece.

Ancient Cypress-tree.-One of the oldest trees in Europe, which may be said to have embraced within the compass of its lifetime the epochs of both the ancient, and modern Cæsar, contrasting its longevity with the comparatively brief duration of human existence, is the cypress of Somma, in Lombardy, respecting which it is affirmed that, there is an ancient chronicle extant at Milan which proves to demonstration that it was a tree in the time of Julius Cæsar. This tree was esteemed so highly by Napoleon, that when he was laying down his plan for constructing the great road over the Simplon, he turned aside from the straight line, in order to prevent injuring it. Its height is 123 feet, and at a foot from the ground it measures 23 feet in circumference.

Durability of Cypress Timber.-There are numerous instances on record of the great durability of cypress timber, which is reckoned to be more lasting than that of the ancient cedar. The doors of St. Peter's Church at Rome, which had been formed of cypress timber in the reign of Constantine, exhibited no signs of decay when Pope Eugenius IV., after a period of eleven hundred years, took them down in order to substitute for them gates of brass.

Pliny records that, the statue of Jupiter in the 
Capitol, which was made of cypress-wood, had existed for six hundred years without exhibiting the slightest symptom of decay; while the cypress doors of the Temple of Diana, when four hundred years old, bore the appearance of being perfectly fresh, and new.

It is not sufficiently well known in this country to be applied to main uses, the best specimen of the tree, perhaps, standing at Stretton Rectory in Suffolk, which measures 63 feet high, its trunk being 2 feet in diameter, it thriving best in a warm, gravelly soil, being well adapted for some of the southern districts of the kingdom, though it has been very little cultivated as a timber tree, being commonly supposed not to be able to stand the keen frosts of the English climate; yet Evelyn seems to have been of a different opinion, for he says that he had upwards of a thousand cypress trees in his garden, and did not lose more than three, or four of them, during the very hard winters of 1663 , and 1665 , and from this number he must have entertained notions of planting upon a rather more extensive scale than ordinarily, though of the subsequent career of these trees we ourselves have no information.

It is supposed that, the wood of the cypress is identical with the gopher wood of which Noah's ark was constructed, a not unnatural supposition, some writers believing that the cedar-wood of biblical history must have been the timber of the cypress tree, from the proved durability of the latter; but 
ad ex-

ing the

$s$ doors

years

sh, and

ntry to

of the

uffolk,

2 feet

y soil, stricts

culti-

d not nglish ferent thou-

lose very mber oon a ough elves

this opinion has doubtless been to a great extent occasioned by the soft nature of the modern cedarwood that is met with, the produce of deteriorated quality of cedar timber, which compares very unfavourably with that of the tree grown in situations favourable to the production of the hardest wood, to which we have before made allusion.

On account of its great durability, at the present time cypress-wood is in common use in the islands of Candia and Malta, for making the inner shell, or coffin, for burying popes, and cther ecclesiastical dignitaries.

Cultivation of the Cypress-tree.-The cones of the cypress become ripe early in spring, and they are treated in the same way as fir cones, being opened by the application of a heat of $100^{\circ} \mathrm{Fah}$., when the seeds fall out. These should be sown in April, in a friable soil, and the plants will make their appearance before the end of May, in most cases. As their tops do not become sufficiently matured to withstand the frost, unless grown in very dry ground, during the course of a warm and ripening summer, with plenty of sunshine, they need to be protected from the severity of the first winter. After standing a year in the seed-bed, the young plants should be removed into nursery lines, and transplanted again every second year,in order to cause their roots to become bushy and fibrous, until the time when they are finally placed in the situations they are intended to occupy.

Many nurserymen pursue the same course as that 
followed in the case of the cedar, and place the young plants in pots, which they remove into larger ones, according to their growth and progress.

The cypress will not succeed in elevated, or exposed situations, but requires to be moderately sheltered.

The White Cedar (C. thyoides).-This tree grows to a considerable size in America, although its progress is but slow, taking eighty years to make it fit for timber, and even then is but of small value. It is mostly found in swampy ground in maritime situations. In this country it is not often met with, as it will not resist frost in exposed situations, except after favourable summers which ripen its shoots; but it forms a pleasing variety of evergreen when disposed in clumps.

Another variety, C. torulosa, a native of the Himalayan mountains, stands an English winter when planted in sheltered situations, forming a beautiful evergreen tree of conical form, with a red bark, and yields ripe cones abundantly. It was introduced into Britain in 1824. 
lace the to larger , or exderately

grows its proke it fit lue. It e situawith, as except ts ; but len disof the r when eautiful rk, and ed into

\section{CHAPTER VIII. \\ BROAD-LEAVED TIMBER TREES.}

THE OAK-ANCIENT OAKS-HISTORICAL OAKS-GOIL SUITABLE FOR THE OAK-COLTIVATION-THE TURKEY OAK-THE CORK OAK-THE EVERGREEN OAK-NUT-GALLS-THE DYEH'S OAK-THE KERARES OAK-THE FULHAM OAK-TURNER'S EVERGREEN OAK-THE LUCOMBE. OAK-THE

The broad-leaved timber trees of Britain are unique in thein character, furnishing landscape ornaments which give shade, shelter, and seclusion, in a manner which may be said to be peculiar to England.

In many foreign countries, especially upon the continent of America, large and handsome trees may be seen growing in masses, sometimes with very large trunks; but rising in close-filled woods, they are bare and destitute of that embowering character, and umbrageous roofing, as it were, that the great spreading boughs, and diffusive spray of our native trees furnish.

Dotted upon park-like meadows, standing in hedgerows, or half obscuring some picturesque village, these stately ornaments of our rural scenery have comparatively short boles, which are almost hidden by the roaming branches, and clustering foliage, upon which the eye rests so complacently, 


\section{4}

ENGLISH TREES AND TREE-PLANTING.

and is so satisfied with the verdant garniture displayed in 'leafy June' and at other seasons.

In some of the aboriginal forests of the American continent, and also in Africa, sylvan giants, it is truc may be seen, whose boles tower towards the sky; but they bear no resemblance to English trees, growing upwards destitute of those spreading branches which distingnish the outlines of our own, which form in many cases successive tiers, or galleries of leafy decoration, and alternate masses of light and shade, which, in the case of the beech-tree, has been described during summer time as a 'great hill of leaves;' while the ash bows in a graceful, and stately manner to the gale, decorated with its easy flowing spray, which often hangs in loose, pendulous masses that are easily stirred by the passing breeze.

Broad-leaved timber trees generally prefer a good quality of land, with only a few exceptions, not thriving in cold, elevated situations, or being able to endure a rigorous climate; neither liking a dry, sandy soil, in which the Scotrh pine, or pineaster would flourish, nor succeeding in low situations that are surcharged with moisture, in which trees of the willow tribe put on all the verdant beauty of which they are capable; but requiring a moderateiy rich soil, and fairly sheltered position that does not lie too low.

An oak is a noble landscape ornament in a proper situation fit for its growth, and it is often regarded as the national tree, symbolical of steadfastness, a type of massiveness and strength ; but in a cold, and exposed 
situation, or in a damp, and low one, it becomes alike dwarfed, and stunted, while in situations the best suited to them, oaks may be found growing in England that measure eighty-five feet in height, with trunks twelve, or thirteen feet in circtimference at a foot from the ground. The broad-leaved trees may be considered, roughly, to include the oak, ash, beech, elm, sycamore, hornbean, locust, plane, Spanish chesnut, birch, and walnut, which all succeed well in average agricultural land throughout the country.

The Oak (Quercus).-The oak, which is generally considered the foremost amongst English trees, belongs to the natural family amentacea ; Monacia polyandria of Linnæus, and is considered a valuable tree in all quarters of the world, from the remotest antiquity being reckoned pre-eminent, on account of its great size, noble aspect, and long duration, qualities which have earned for it the title of 'monarch of the woods.'

It was considered sacred by the ancient Greeks and Romans, as well as by the Gauls and Britons, being dedicated by the Romans to Jupiter, the peasantry crowning their heads with wreaths of oakleaves before commencing their harvests; while the solemn ceremonies of the Druids were enacted beneath its broad-spreading branches, cutting the misletoe from off its trunk being associated with one of their most mysterious, and sacred rites, in proximity to rude temples, at times formed of huge stones of enormot. weight and size, some of which are now 
standing, and puzzle modern beholders to discover by what mechanical agency these enormous stones, stuck up endways, with another of great size placed across their tops, could ever have been raised into the position they now occupy ; one of the most curious of these, perhaps, unlike those of Stonehenge, being a solitary specimen, standing near Maidstone, called Kits Cotty House. -

The oak lives to a great age, and possesses such strong vitality that, it continues to vegetate after the core has decayed, and disappeared, leaving merely a husk of timber outside, but having strength enough, even at such an advanced age, to produce both leaves and acorns.

Ancient Oaks._Gilpin, in his 'Forest Scenery,' says that, there are a few venerable oaks in the New Forest that chronicle upon their furrowed trunks ages before the Conquest; but the more accurate Evelyn counted in the same place, in the sections of some oak trees, 300 and 400 concentric rings, or layers, which each record a year's growth.

The most celebrated of these venerable trees was perhaps the Winfarthing Oak in Norfolk, reputed to have been called the 'old oak' during the reign of William the Conqueror, and was said some years back to be 1,500 years old, a plate being attached to the tree bearing this inscription and date:- 'This oak in circumference, at the extremity of the roots, is 70 feet, in the middle, 40 feet. -1820 .'

The King's Oak in Windsor Forest is represented 
t.

discover is stones, ze placed ised into st curious ge, being ne, called sses such after the merely a enough, th leaves

Scenery,' the New nks ages e Evelyn some oak s, which rees was puted to reign of e years ached to - This

e roots, resented taros 


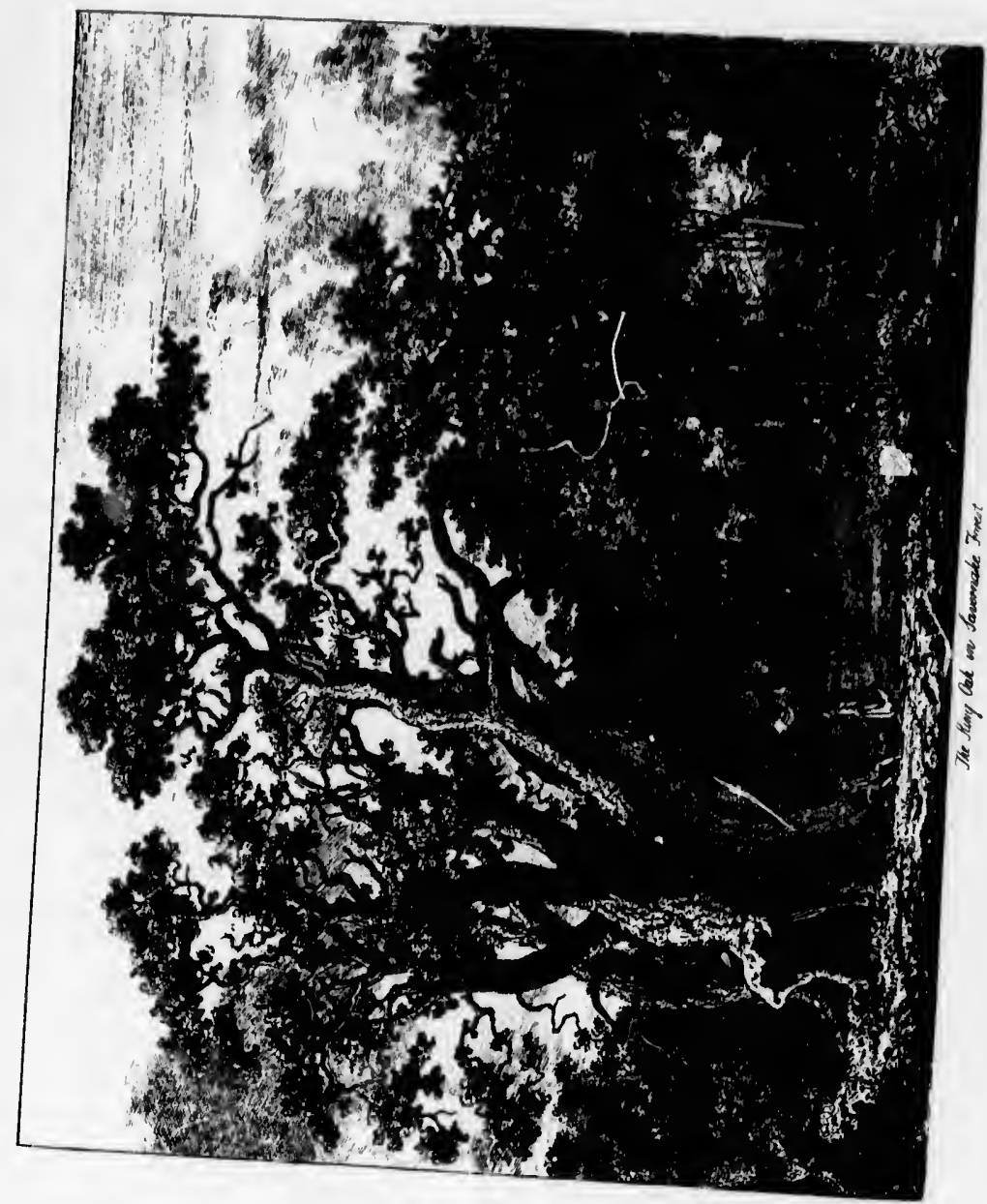


as having been a favourite tree of William the Conqueror, and hence its name, being the largest, and oldest in the forest, and reputed to be upwards of 1,000 years old, measuring, some twenty years or so back, twenty-six feet in circumference at three feet from the ground.

Another out of the number of ancient oaks that are celebrated, also bearing the name of the King's Oak, that stood in Dennington Park, had a longer bole than ordinarily, and ran up to fifty feet before a knot or bough appeared, the base squaring five feet entirely solid; while the Queen's Oak was forty feet, and then branched out into two enormous arms, the base squaring to four feet. Dennington Park, near Newbury, was once the residence of Chaucer, and an oak, said to be planted by the poet, and called Chaucer's Oak, was a stately tree, there being others well evidenced to be of a greater age than three hundred years, which may be easily enough believed, though Gilpin's statement as to the enormous age of oak-trees is not founded upon any incontestable proof, and is therefore open to considerable doubt.

Another oak in Holt Forest, in Hampshire, which was measured in 1759, was found to be thirty-four feet in circumference at seven feet from the ground, but twenty years afterwards its circumference had not increased a single inch.

An oak felled at Norbury, on the authority of Dr. Plott, is stated to have been of the enormous circumference of forty-five feet, so that, when it was 
lying prostrate upon the Eround, two horsemen on either side of the trunk were concealed from the view of each othe. He also mentions an oak at Keicot, beneath the shade of which 4,374 men had sufficient room to stand upright, from the computation of cubical space beneath the spread of its branches.

In 'Lauder's Gilpin' it is stated that, in Bagot's Park, Staffordshire, there is an immense oak, twentyeight feet in circumference at five feet from the ground, the branches extending forty-eight feet from the trunk in every direction. ' It contains 877 cubical 'zet of timber, which, including the bark, would liave produced, according to a price offered for it in 1812, the sum of $202 l$. 14s. $9 d$. This tree is quite fresh, vigorous, and beautiful.' But by far the largest sum that was ever realized by one tree was in the instance of the Gelonas Oak, which has often been mentioned by different writers as standing a few miles from Newport, in Monmouthshire, that was felled in 1810. According to the 'Gentleman's Magazine' for 1817 , it is said to have been sold while standing, in the first place for 100 guineas, under the belief that it was unsound, but was resold while yet standing for $405 \%$. to snother speculator. The expense of converting the tree into timber was $82 l$, making in all $487 l$, and subsequently it was sold again for $675 l$. It is said to have contained 2,426 feet of cubical timber, its bark being estimated to weigh six tons.

Historical Oaks.-Most English counties possess historical trees, that have been associated with im- 
portant events, though, doubtless, a good deal of the fabulous is connected with them. About a century ago the oak in the New Forest, against which the arrow of Sir William Tyrrel is said to have glanced before it inflicted the mortal wound upon William Rufus, was described as sitll standing, though in such a state of decay that, Lord Delaware caused a monument to be erected to mark the spot. An oak was standing some years ago, if it no longer remains, at Torwood Wood, in Stirlingshire, beneath the shade of which William Wallace is reputed to have assembled his followers and urged them to deliver their country from the tight grip of Edward; while Gilpin, who leans to the marvellous, speaks of Alfred's Oak at Oxford, which was a sapling when that monarch founded the university. There are, however, abundant well-authenticated records of trees that have attained a vast age, without the necessity of pinning our faith to anything that savours of the fabulous. The Parliument Oak in Clipstone Park, the property of the Duke of Portland, is said to have derived its name from the fact that a Parliament was held under it by Edward I. in 1290, the girth of the trunk being twenty-eight and a half feet. The park was formed before the Conquest, and was seized by William, who made it a royal demesne. The Shelton Oak near Shrewsbury is associated with Owen Glendower, who upon June 8, 1403, mounterl it, that he might obtain a better view of the battle of Shrewsbury, then being waged, on his arrival near the scene of action, with 
12,000 men, its girth being about twenty-six feet at four and a half feet high.

Dr. Hunter describes the great Cawthorp Oak, which stood near the village church of Cawthorp, near Wetherby, in Yorkshire, in his Notes to 'Evelyn's Sylva,' as it stood in 1776. 'The dimensions are almost incredible. Within three feet of the surface it measures sixteen yards, and close by the ground twenty-six yards, or seventy-eight feet. Its height in its present ruinous state is almost eightyfive feet, and its principal limb extends sixteen yards from the bole. Throughout the whole tree he foliage is extremely thin, so that the anatomy of the ancient branches may be distinctly seen in the height of sunimer. When compared with this, all other trees are but children of the forest.' Fifty-three years afterwards, namely in 1829, it was again described in Strutt's 'Sylva Britannica' by the Rev. Thomas Jessop. 'The Cawthorp Oak is still in existence, though very much decayed. At present it abounds with foliage and acorns; the latter have long stalks, the leaves short ones. The dimensions are as follows : Height, forty-five feet; circumference close to the ground, not including the angles, sixty feet-at one yard high, forty-five feet; extent of principal branch, fifty feet, being an increase of two feet in about half a century. I am inclined to think the original dimensions were those given in the "Sylva." The oldest persons in the neighbourhood speak of the tree" as having been once much higher; 
and were the angles included in the measurement which project from the lower trunk, the circumference might be made out twenty-six yards. It is said by the inhabitants of the village that, seventy persons at one time got within the hollow of the trunk; but on inquiring, I found many of these were children, and as the tree is hollow throughout to the top, I suppose they sat on each other's shoulders; yet, without exaggeration, I believe the hollow capable of containing forty men.'

The Boddington Oak, in the Vale of Gloucester, was recorded about the year 1850 to be fifty-four feet in circumference at its base. In 1783 the larger branches had gone, but the hollow cavity in its centre measured sixteen feet at its greatest diameter, the top being formed into a recular dome, while the young twigs on the decayed top had small leaves about the size of those of the hawthoru tree, bearing an abundant crop of acorns. The hollow spaces had a door and one window, which with a little labour might have been converted into a very commodious room.

Although not so large a tree as the preceding, the Fairlop Oak, in Essex-to which it was custor ary for Londoners residing in Whitechapel, Mile End, and other eastern portions of the metropolis, on OakApple Day to make special trips, or outings, as they are termed by them-was of very great size, being between six and seven feet in diameter at a yard high from the ground ; and the Corporation of London, who have lately been instrumental in preserving Epping 
Forest from the encroachments of neighbouring landowners, and retaining it for the use, and recreation of the London working-classes, deserve great praise for what they have done. Like the Boddington Oak, which was hollow in the centre, Damorg's Oak, in Dorsetshire, had a cavity which measured sixteen feet long, and twenty feet high, and at the time of the Commonwealth it was used by an old man as an alehouse for the entertainment of travellers. Report does not say whether he had a license, or paid rates and taxes, but its circumference is described as being sixty-eight feet. A dreadful storm shattered this majestic tree, and in 1755 the last remains and vestiges of it were sold for firewood. The Greendale $O a k$, in Nottinghamshire, in 1724 , had a roadway cut through its trunk sufficiently wide to allow a carriage and four horses to pass through it, the circumference of the trunk above the arch being thirty-five feet, the height of the arch being ten feet, and the circumference of the trunk about the middle upwards of six feet.

Many of these historical old trees are now gradually disappearing. The Royal Oak, at Boscobel, in which Charles II. concealed himself after the defeat at Worcester, has gone; and though several trees were raised subsequently from its acorns, which certain loyal subjects collected, even these seem to have become lost in obscurity, and no trace of them is to be found. We could furnish many more instances of celebrated old oak-trees ' full of story, and haunted 
g landtion of ise for

Oak, $a k$, in en feet of the in aleieport rates being this and ndale y cut riage ence , the afer$\operatorname{six}$ du, in feat

by the recollections of the great spirits of past ages,' but we have quoted sufficient for our purpose to illustrate the great age, and durability of the ' monarch of the woods;' and the compunction of the spendthrift in later life whose follies during his inconsiderate youth compelled him to fell his 'ancestral oaks' to meet his pressing necessities, may well be imagined.

Soil suitable for the Oak.-The oak, when associated with other trees growing upon rich soil in sheltered valleys, becomes a tall tree, with a straight trunk; assuming a dwarf, and bushy habit in exposed situations, but its natural growth can only be estimated when grown alone, under the most favourable conditions, where the roots form a spreading basis on the surface of the ground, which is thus grasped as a sure, and firm foundation, the trunk assuming proportions of massive compactness, bearing ponderous, horizontal limbs, the roots perhaps penetrating to a further distance than those of any other tree. On this account its health, and continued prosperity must naturally, in a great measure, depend upon the nature of the subsoil, a strong deep soil elevated a considerable distance above stagnant water being required; but yet it will grow fairly well upon sandy, or gravelly land, more especially when it is mixed with a certain amount of clayey particles, often succeeding very well upon soils of opposite qualities, that are too poor to pioduce either elm, or ash, which will be accounted for $n$ this denendence of the oak more 


\section{4}

ENGLISH TREES AND TREE-PLANTING.

upon the under stratification of the land, than the upper surface.

The tree, breaking out into leaf late in the scason, is yet often injured by frosts before they take their final departure ; and when forming oak plantations, it has been found prudent to associate them with other faster growing trees, to serve as nurses, or shelter, as beech, larch, Scotch pine, or spruce fir. In exposed situations, with this shelter, the young trees soon take firm hold of the soil, and do not suffer from the confinement, until the time comes round to relieve them of their neighbours as soon as they have performed their allotted tasks, after which the young trees often advance very rapidly, and often produce both summer, and autumn shoots, these Lammas growths, as the autumn shoots are called, being peculiar to the oak.

While thus standing in plantations, or surrounded by other trees during the early stages of its growth, it is generally erect, and pliant ; but when a greater space is allotted to it, its growth and habit begin to alter; and before its top reaches its full height, which will depend in a great measure both upon the amount of exposure, and the quality of the soil, its outline will become bolder, and more in accordance with its well-known characteristics, its gnarled limbs being firmly knit together, assuming various ramifications, and bold outlines, that it never would have attained if it had continued crowded.

Cultivation.-The acorns become ripe and drop 
in the

cason, their ons, it other er, as oosed take conthem med often sumths, $r$ to

unt

line its ing ns, led

from the tree about the end of autumn, and they may be sown any time from thence up to the beginning of March. A difference in the manner in which the acorns grow on some oak-trees has been pointed out by a writer in the 'Quarterly Review,' which he attributes to the substitution of a foreign species of oak (but which may be rather looked upon as a variety). He says: 'We may here notice a fact long known to botanists, but of which our planters and purveyors of timber appear to have had no suspicion, that there are two distinct species of the oak in England, the Quercus robur and the Quercus sessiliflora; the former of which affords a close-grained, firm, solid timber, rarely subject to rot; the other more loose and sappy, very liable to rot, and not half so durable. This difference was noticed so early as the time of Ray; and Martin, in his 'Flora Rustica,' and Sir James Smith, in his 'Flora Britannica,' have added their testimonies to the fact. The second species is supposed to have been introduced some two or three years ago from the Continent, where the oaks are chiefly of this latter species, especially in the German forests, the timber of which is known to be very worthless. But what is of more importance to us is that, de fucto, the impostor abounds, and is propagated vigorously in the New Forest and other parts of Hampshire, in Norfolk, and the northern counties, and about London; and there is too much reason to believe that, the numerous complaints that were heard about our ships being infected with what was 
called, improperly enough, dry rot, were owing to the introduction of this species of oak into the naval dockyards, where, we understand, the distinction was not even suspected. It may thus be discriminated from the true old English oak: the acorn-stalks of the robur are long and its leaves short; whereas the sessiliflora has the acorn-stalks short and the leaves long. The acorns of the former grow singly, or seldom two on the same foot-stalk-those of the latter in clusters of two or three, close to the stem of the branch. We believe the Russian ships of the Baltic, that are not of larch, or fir, are built of this species of oak; but if this were not the case, their exposure on the stocks, without cover, to the heat of summer, which, though short, is excessive, and the rifts and chinks, which fill up with ice and snow in the long winter, are enough to destroy the stoutest oak, and quite sufficient to account for their shortlived duration.'

That trees deteriorate we have abundantly shown in the foregoing pages, and we have made this slight digression in order to lay before the reader the opinion expressed therein, with the view of showing the necessity of having good reliable seed. As the smallest acorns bring plants that for some years continue to be of feeble growth, it will be found the best course, as acorns are generally plentiful enough, to sift them through a riddle, and separate the largesized ones from the small, and use only the former.

They should be sown in beds four feet wide, and 
rolled, or beaten down upon them with the back of a spade to keep them in position, one busliel of acorns being sufficient for a bed twenty-five feet long of this width. There should be alleys between the beds, fifteen inches wide, the surface-soil from these alleys being removed to make a cover for the acorns, which in light soil should be nearly an inch in depth, but in heavy soil, lialf an inch will be found a sufficient covering.

If sown in winter, or early spring, the covering should be spread roughly, but at the same time the seed must be properly, and thoroughly covered, and be left in this rough state until April, when it should be made smooth in fine weather, and carefully raked. The pulverising effects of the frosts will then liave been duly excrted, and the seeds of weeds will have vegetated, which can be effectually dealt with by the rake, and early in May, the oak plants will show themselves above ground through the surface, which las been made soft, and through which they will emerge without difficulty.

As late frosts often prove very injurious to the young plants, a slight covering should be spread over them of some kind or other, which may consist of boughs of evergreens, Ieaves, straw, cr litter, and left till the end of May, when it should be taken away, and the beds kept clear from weeds throughout the
seasoll.

It is usual to remove the plants from the seed-bed into nursery lines at two years, but sometimes they 
are transplanted at a year old, which can be done at any time in open weather during the winter, or spring. When they are taken up from the seed-bed, the extremity of each tap root should be cut off, to encourage a fibrous growth of root, taking pains in the first place during the removal that their lateral fibres are not injured, to prevent which the ground should be carefully loosened with a fork. The nursery lines should be about a foot and a half apart, or rather less, the plants standing about six inches from each other. After being in the nursery lines a couple of years, they will generaily stand from two to three feet high, and are then fit for being planted out. Should, however, larger-sized plants be required, they should be again transplanted at wider intervals, and remain for two or three years longer, according to the purpose for which they are designed; plants intended to become hedgerow timber, for example, requiring to be very stout, and strong, as small ones are often spoilt or injured by vermin. If an oak plant is allowed to remain longer than two years in the seed-bed undisturbed, it sends its tap root down into the soil, and consequently does not acquire that bushiness which is produced by frequent transplantation, and which is so necessary to the wellbeing of a transplanted tree, as a means of quickly adapting itself to its new position. Although these undisturbed plants may look to the eye strong and healthy, they will be useless for planting out, if good, reliable plants are looked for. 
done at spring. the exto enin the 1 fibres should $y$ lines er less, other. years, thigh, , howuld be ain for urpose to beto be spoilt ed to undis1 , and which ich is tree, posilook seless boked

The Turkey Oak, or Mossy-cupped Oak (Q. Cerris). - This is a native of Italy and Spain, and the middle and south of Europe generally, as well as the west of Africa. It is of an elegant appearance, being as lrardy as the common oak, but grows faster, and succeeds on poorer soil, the leaves being oblong and pointed, of a glossy green above, and inclining to white beneath, of a somewhat hoary hue, standing upon slender footstalks, the acorns being small, and having rough, prickly cups, the leaves dying in autumn, but, like those of the young beech, adhering to the tree throughout the winter.

The acorns ripen like those of the common English oak, the modes of cultivation being also alike, but the young seedling plants are generally taller than the common oak at the same age, it being generally considered better to transplant them when one year old, in preference to allowing them to remain for two years in the seed-beds. In good soi!, the Turkey oak will attain the height of forty feet in twenty years, with girth of trunk in proportion, but thirty feet in that period may be considered the common average, generally rising with a straight trunk, like that of the larch, large in proportion to its lateral branches, but it is destitute of that imposing form which distinguishes the Quercus robur. It was introduced into England in 1735, some of the oldest specimens now standing in the southern counties of the kingdom, measuring upwards of a hundred feet in height, th species being remarkable for the great number 
varieties it produces, apparently appearing to incline to hybridise with the evergreen oak, it being not u11frequently the case that, in a seed-bed of Turkey oaks a considerable number of sub-evergreen plants are to be found.

The Cork Oak (Q. suber).-The cork-tree is found in Portugal, Spain, Italy, the southern parts of France, and the Barbary States, Spain and Portugal supplying the greater portion of the cork of commerce which is consumed in Europe. It affects dry, and hilly situations, and seldom reaches above an altitude of forty feet, the outer bark of the tree being the cork, which is its most valuable product. The Greeks and Romans commonly made use of cork as floats for their fishing nets, and buoys for anchors, the useful applications of cork being well known to the ancients, which is evidenced by the writings of Theophrastus, Pliny, and other authors; during the siege of Rome by the Gauls, Camillus, who was sent to the capitol througl the Tiber, wearing a life-preserver of cork beneath his dress. It is usual to clear the trunk of its branches when the tree is young, up to a height of eight, or ten feet, and when it is from twenty, to thirty. years old, strip off the outer coating of bark, which is then found to consist of a formation of coarse, porous cork, intermixed with woody fibre. This is removed in July, or August, and after it is cleared off, it mostly takes another ten years to form another covering of cork, which is of better quality than the first obtained; but it is not until another interval of eight, or ten 
incline

years, when the operation is again repeated, that the best quality of cork fit for wine bottles is produced, when the cork will have attained a sufficient thickness for the purpose. The trees are then always disbarked at similar intervals, which is carcfully done, so as not to injure the inncr skin, or wood of the tree. It would naturally be supposed that, this operation would materially affect its growth, but so far from its proving to bc prejudicial, it is said to have the oppositc effcct, the quality of the cork improving with the increased age of the tree. Loudan describes a large oak-trec at Mamhead, in Devonshire, as being sixty feet high, with a trunk twelve feet in circumference above the swell of the roots, standing alonc about twelve miles from the sea, and about 450 feet above its level, its head being compact, and oval, having grand, massive branches, each of which would form a tree by itself of noble dimensions, which are covered with rugged, corky bark, rescmbling richly chased frosted silver, which contrasts finely with the dark-green, luxuriant foliage.

On the Continent, after the bark has becn well scraped, it is cut into pieces and slightly charred, for the double purposc of contracting it, and destroying the insects (which gives it the black appearance outside that may bc noticed), and is then pressed flat with stones; but in Catalonia, after being cut into pieces, it is boiled in watcr, which is said to improve the quality of the cork.

About one hundred and twenty millions of corks 
are annually consumed in France, and large quantities are also imported into Britain; the bottled-beer trade as well as the wine merchant consuming a great many.

The Evergreen Oak (Q. ilex).-The common evergreen oak is a handsome tree, being a native of Europe and the south of Africa; but has been cultivated in Britain from a remote period. It is a very handsome evergreen, the foliage beilıg very abun. dant, of a rich dark green, having a fine polish, glossy on top with a downy tinge beneath, and grows in a smoky atmosphere better than most cvergreens, the tree being apt to strike out into varieties, of which the principal are integrifolia, the common ; serrata, the notch-leaved; and oblonga, the long-leaved; sometimes even the lower leaves differing from those on the topmost branches. They remain green all the year, and do not fall till they are pushed off by the younger ones in the spring, the acorns being smaller in size than those of the common oak, but of the same shape. The tree blossoms in May, or June, producing male flowers or catkins, which are from one, to two inches in length on the shoots of the preceding year; but the female flowers are produced on the newly formed twigs, the acorns coming to maturity during the second year, and the tree endures seaexposure better than any other European oak.

If allowed a sufficient space it will commonly form a very large trunk, which it conceals with its foliage that it wears down to the surface of the ground. The timber is tough, strong, and heavy, and is generally 
considered to be of much the same commercial value as that of the common oak.

Nut-galls.-Nut-galls are produced on various species of the oak, and consist of a morbid excrescence produced by the puncture of a winged insect of the genus Cynipidce, to which Olivier has given the name of Diplolepis Gallo Tinctoria, the excrescence being of a globular form, with an unequal, and tuberculous surface. It is produced on the young shoots of the trees, and contains within it the eggs which the insect has deposited; the best galls being gathered before the transformation of the insect, as in that state they are heavier, and contain more of the tannin principle.

Perhaps the most remarkable are those wlich are found on the male blossoms of the British oak. The catkins appear in May, and are from one to two inches long, and having shed their polien become deciduous, and drop from the tree in June in the ordinary way; but if they have been attacked by the insect while in a growing state, they remain on the tree till the galls are perfected.

The Dyer's Oak (Q. infectoria).-Although the nut-gall is common to almost every species of the oak, the nut-galls of commerce are obtained from the Quercus infectoria, which is a species of shrub, seldom rising more than six feet in height, and being very common in Asia Minor, the first accurate description of it being given by M. Olivier, who introduced the shrub into France, where it grows well in 


\section{4}

ENGLISH TREES AND TREE-PLANTING.

the open air, and is cultivated as a garden plant; the galls being peculiarly astringent, according to Sir Humphry Davy, 500 parts containing 180 parts of soluble matter, principally composed of tannin and gallic acid.

The oak-apple is an excrescence of the same nature, though effected by a different insect; the instinct which causes certain insects to choose particular vegetable bodies on which to deposit their eggs being a remarkable provision of nature.

Knapp says, "The insect that wounds the leaf of the oak, and occasions the formation of the nut-gall, and those which are likewise the cause of the apple rising on the sprays of the same tree, and those flowerlike leaves on the buds, have performed very different operations, either by the instrument that inflicted the wound, or by the injection of some fluid to influence the action of the parts. That extraordinary hairy excrescence on the wild rose, likewise the result of tise wounds of an insect (Cynips rosa), resembles no other nidus required for such creatures that we know of: and those red spores on the leaf of the maple are different again from others. It is useless to enquire into causes of which we probably can obtain no certain results ; but, judging by the effects prodnced by different agents, we must conclude that, as particular birds require, and fabricate from age, to age, very different receptacles for their young, and make choice of dissimilar materials, though each species has the same instruments to effect it, where, generally speak- 
ant; the to Sir parts of nin and he same the ine partieir eggs leaf of nut-gall, re apple flowerdifferent ted the afluence y hairy esult of bles no e know iple are enquire no cerced by rticular ery difchoice as the speak- ing, no sufficient reasons for such variety of forms and texture is obvious, so is it fitting that, insects should be furnished with a variety of powers and means to accomplish their requirements, having wants more urgent ; their nests being, at times, to be so constructed as to resist the influence of seasons, to contain the young for much longer periods, even occasionally to furnish a supply of food, or be a storehouse to afford it when wanted by the infant brood.'

The cynips, according to Reaumer, is furnished with a kind of needle in a sheath, which has extraordinary capabilities of extension, arising from the system of construction peculiar to the body of the insect, so much so that, this instrument can be extended to double the length of the creature itself, and forms in a lengthened perforation a nest for its offspring, while the young in the same manner, when the proper time comes round, pierce their way outwards from the vegetable enclosure which has been their protection.

The Kermes Oak (Q. coccifera).-Another oak-tree which yields a commercial product is the Kermes Oak, which is commonly met with all along the shores of the Mediterranean, which partakes of the nature of a shrub, seldom exceeding a height of twelve feet. The leaves are oval, and undivided, smooth on their surface, but indented at the edge, which is covered with prickles, resembling those of the holly. The trunk is feathered to the bottom, and the acorns are smaller than those of the common oak. 
It is from this tree that the kermes are gathered with which the ancients used to dye their garments the rich colour called coccineus, or coccus, as celebrated in its way as the purple of the Phœnicians which was obtained from the testaceous mollusk, murex, the latter being neglected after the kermes of the oak was introduced. It is still used in the Barbary States, and the Levant, for dyeing the round scarlet caps so much affected by the Greeks, forming part of the national costume of the Albanians; but this in its turn has given way to a yet more successful dye product more recently discovered, that of cochineal, an insect that is found upon the Cactus opuntia.

The Fulham Oak.-The Fulham oak is a hybrid between the Turkey oak, and the cork-tree, that was first grown at a nursery ground at Fulham, being a lofty tree nearly eighty feet high, the trunk at a foot from the ground measuring thirteen feet. It is a fine, broad-leaved evergreen, that can be readily propagated by being grafted on either stocks of the cominon, or the Turkey oak. The acorns which have been produced abundantly from the original tree, have in their turn produced other very interesting varieties, which have been propagated by grafts. Seedlings from the original tree have been found to 'sport' very much, so that they cannot always be depended upon to reproduce the true variety now known as the Fulham Oak, the only certain method for its reproduction being by grafting. The grafts will spring 
freely upon stocks of tolerable vigour, and will often grow three or four feet during the course of the first summer.

Turner's Evergreen Oak.-Turner's evergreen oak is another interesting variety, being a hybrid between the common British, and the evergreen oak. In appearance it very much resembles the former, but in autumn its foliage assumes a more massive, and darker green appearance, being the fastest growing evergreentree that is found suitable for the climate of North Britain. It resembles other hybrids in needing for its successful propagation to be grafted on healthy stocks of the common species of oak, upon which it will grow fast, and attain the height of four, or five feet in a couple of years, after which it will proceed at about the same rate as the corrmon oak, till it gets twenty years old, its rapid growth when young being often a great recommendation to many planters, and it is also a very ornamental tree.

The Lucombe Oak.-This is another hybrid oak, which is also a sub-evergreen, remarkable for the rapidity of its growth, being between the Turkey oak and the cork-tree. It was originally produced rather more than a century ago at Exeter, and there are now a good many trees of this variety scattered over the southern districts of England, many of which are very handsome specimens.

The Scarlet Oak (Q. coccinea).-The scarlet oak is indigenous to Pennsylvania, New Georgia, and New Jersey, and was introduced into Britain about the end 
of the seventeenth century, and in many situations it grows with greater rapidity than the common oak. The leaves are oblong, deeply sinuated, and of a bright shining, green colour, varying exceedingly in shape and size on different tress, and even on the same tree at different stages of their growth, all being remarkably handsome, and produced on long leaf stalks. The freest-growing, and best trees, sometimes have leaves that are a foot long, and six or seven inches broad. They are deciduous, and the first frosts of autumn, or early winter, change them into bright yellow, or red, which ultimately ripen into the brightest shades of crimson, or scarlet.

There are many fine specimens of this tree to be seen in different parts of England: one at Croome, which attained the height of 100 feet in seventy-five years, and another at Strathfieldsaye, of similar proportions, the species producing acorns in this country, but the trees are usually propagated from American seed, which needs to be sown immediately upon its arrival here, owing to the confinement to which the accrns are subjected in their journey across the Atlantic, which is apt to produce fermentation, the slightest touch of which causes them to sprout, and unless they are immediately sown, they may possibly lose their vitality. 'Their method of cultivation is the same as that pursued with other oaks, but as they have a tendency to make bare roots, which results in a stunted growth of the plant, they should be removed early into nursery lines, and planted in the 
IRED, WHITE, AND BLACK AMERICAN OAKS. 189

situations they are intended to occup: before their roots become too much developed.

The red, white, and black American oaks each comprehend a great number of species, many of which become fine, large, spreading trees, but the timber of nearly all of them is soft and porous, and on this account, are not profitable for cultivation. 


\title{
CHAPTER IX.
}

Broad-Leaved Trees (continued).

\begin{abstract}
THE ASH-CULTIVATION-VARIETIES-THE BEECH - COLTIVATION - THE KLM-THE ENGLISH ELM-COLTIVATION-THE WYCH RLM-CULTIVATION-THE HUNTINGDON ELM-THE DUTOH BLM-THF AMERICAN RLM-VARIATION OF THE ELM-THE WEEPING ELM.
\end{abstract}

The Ash (Fraxinus excelsior). - The ash belongs to the natural family Alcinece polygamia, dicecia of Linnæus, the tall, or common ash being indigenous to Britain, taking its station near the oak in common estimation, and is equally as useful for agricultural purposes.

It thrives best in a deep, sweet, hazelly loam, preferring a situation towards the bottom of a hill, especially when it slopes towards a river, whose influence its roots may feel during the heats of summer, without the soil being absolutely wet.

The ash may often be seen growing in hedgerows in England, which is a very improper situation for it, for it causes a large barren circle around it upon which nothing will be produced, the drip of the ash being injurious to other plants, as may often be seen in a cornfield; though in marshy situations, as the roots run down for a considerable distance they act as drains, and are therefore in such a case beneficial. Hence the proverb-'May your footfall be by the 


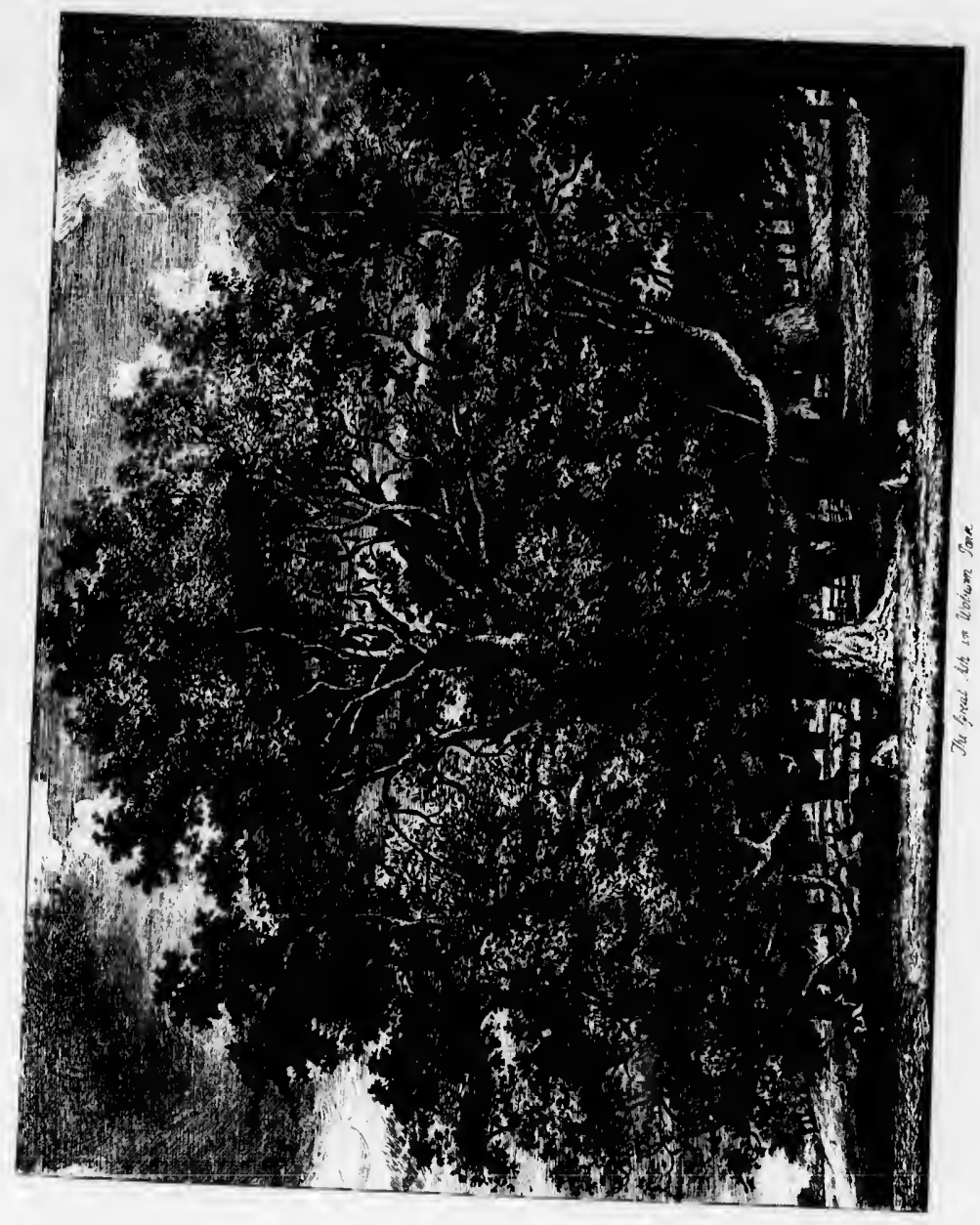



root of an ash,' equivalent to, 'May you obtain a firm footing.'

Ash-trees are most successfully grown when they are allowed to rise in masses by themselves, but they are often grown for the sake of variety in conjunction with other trees. In the case of the Scotch pine, they shade the tree too much, while the oak gets clothed with a substantial framework of spray and leaves, and does the same; the ash being a loose-headed, open tree when planted in groups by themselves not doing this, for if the branches slightly interfere with one another, no great harm follows.

In the case of most trees, hard and durable timber is the result of a slow growth, but this is not the case with the ash, which requires a free, quick, and unimpeded growth to develop its special qualifications, which are strength, toughness, and elasticity; and its growth should therefore be hastened by a good soil, and somewhat shaded situation; in those instances where its advancing career is stopped by a sour, wet subsoil. or its freedom of growth is checked by a naturally poor soil, the wood becomes brittle, and shaky.

As a landscape decoration the ash is a very valuable tree, swaying gracefully to the breeze, and pleasing the eye with its easy outline.

It succeeds in elevated situations, provided it has shelter, as may be seen from the specimens which stand in the glens, and ravines of hilly districts; when at a foot from the ground, trunks are some- 
times to be found that will measure ten feet in circumference. It carries its principal stem ligher than the oak, its whole appearance wearing an air of lightness, the looseness of its leaves corresponding with the lightness of the spray, its bloom presenting a beautiful appearance. Gilpin, in his work on 'Forest Scenery,' calls the oak the Hercules of the Forest, and the ash the Venus; its principal drawback as a landscape decoration being that, it sheds its leaves very early, so that instead of contributing its quota to the variegated tints which adorn the autumnal woods, it can only present wide blanks of desolated boughs, and in comparing it with the oak, in old age it loses that grandeur and beauty which the oak retains to the last.

The bole of the ash does not attain to such a thickness as some of the other forest trees, though Arthur Young mentions one that he met with in Ireland that had reached the height of nearly eighty feet in thirty-five years. It is not desirable to allow the ash to stand too long, lowever, for it is found that, the timber of the old trees is inferior to those of a lesser age. Ash-timber is applied to a great number of agricultural, as well as other uses. It enters largely into the construction of ploughs, harrows, axle-trees, waggons, carts, and carriages of all kinds; and especially for the handles of tools, as ricks, forks, spades, picks, shovels, and mattocks. It is prepared for dairy utensils, and used for making kitchen tables, chairs, and benches. The cooper 
makes his hoops from it, its toughness and pliability rendering it peculiarly fitted for this purpose; while for hop poles it is better perhaps than any other kind of wood, as well as for making crates, or being used for any purpose where elasticity and strength is an
object.

Cultivation.-The ash is propagated by seed which is fully ripe by November, when it should be taken from good trees, and mixed with sand, in the proportion of two bushels to one of seed, and be laid in an open pit, made in a light, porous soil. They should be allowed to remain in this pii for fifteen months; the mixed seed and soil being turned over at least lualf a dozen times during this interval. About the end of February (fifteen monihs after they have been gathered) the seed sliould be sifted, and sown if possible in sandy loam, the beds being formed into the most usual width, of four feet, with an alley between, a foot in width. The surface of the beds should be uncovered, and the soil pushed into the alleys, sufficient being displaced to give a covering of three quarters of an inch, and the seeds should lie about half an inch from one another.

After standing for two years in the seed-bed, the plants should be removed into nursery lines, a foot and a half asunder, the plants standing six inclies apart in the rows. When they lave stood thus for a couple of years, they will be fit for finally plant-
ing out.

Planting may be performed in October or Novem. 
ber, or March and April ; and, as before stated, they will flourish best when planted in masses by themselves; and although in some cases they may require nurses, in their permanent character they must not be interfered with by any other tree.

Varieties.-The varieties of the ash are the weeping ash (pendula) (very commonly trained to form an arbour on a grass plot), which was first discovered growing in a field at Gamblingay in Cambridgeshire ; the yellow-barked (jaspidea), and the green-coloured (atrovirens). The most important of the American varieties are the white ash ( $F$. Americana), a beautiful tree; the black ash ( $F$. sambucifolia), having buds of a deep blue colour; the red ash ( $F$. tomentosa), with bark of a deep brown colour, the lower surface of the leaves and shoots being covered with a reddish down; the blue ash ( $F$. quadrangulata), the bark of which is said to yield a blue dye; and the Carolinian ash ( $F$. platicarpa), distinguished by its nearly round acuminated leaflets, of which there are only commonly two pairs, with an odd one, and of smaller size than the other varieties mentioned. -

The Beech (Fagus sylvatica) —natural family Amentacex, Monxecice, Polyandria of Linnæus.-The beech is generally regarded as being one of the stateliest, and most handsome of our English trees: attaining a large size, and contributing greatly to our parks and pleasure grounds; the trunk being massive, and covered with a smooth, shining bark; rising to a great height, with widespreading, and umbragcous hori-

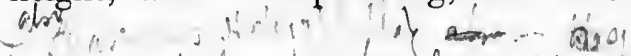

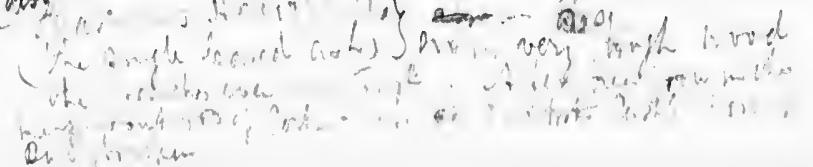


NG.

tated, they

by themay require must not

the weepto form an discovered idgeshire ; n-coloured American a beautiful ving buds tomentosa), er surface a reddish he bark of Carolinian arly round only commaller size

nily AmenThe beech stateliest, attaining a parks and ssive, and to a great cous hori- 


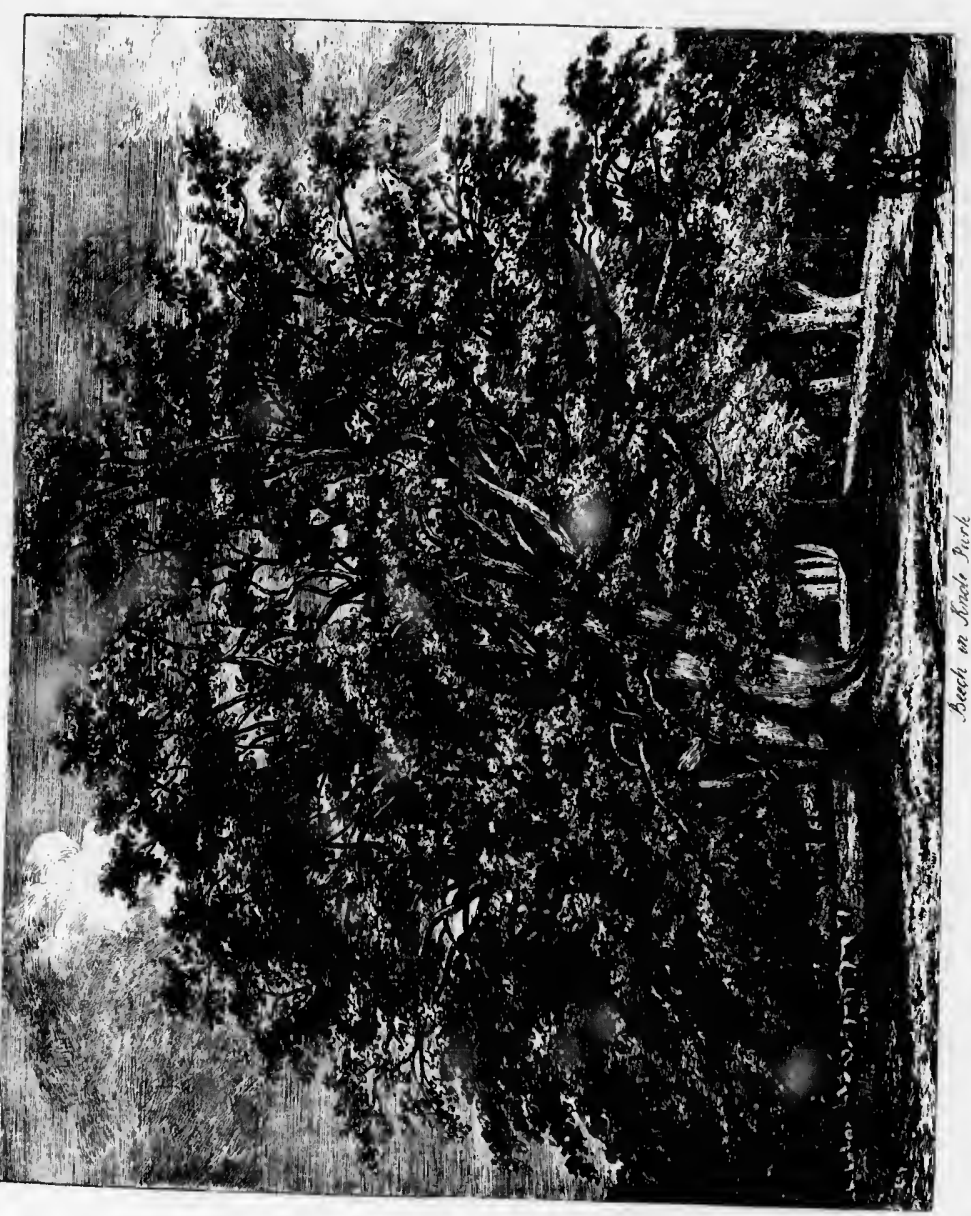


zontal branches, covered with delicate green leaves while young, but becoming harder, and darker, as they reach maturity.

The buds of the common beech begin to expand about the middle of April, the leaves coming out about a week afterwards; the flowers appear about the middle of May, or a little earlier, by the first week in June being in full blossom. The mast, or seed, consists of an angular nut encased in a prickly capsule, which gets ripe in autumn. It thrives best in a chalky or strong soil, and is found growing in masses on the chalk hills of Kent, Surrey, Hampshire, and Sussex, as well as upon the Cotswold Hills of Gloucestershire, in Buckinghamshire and Hertfordshire; some very fine specimens of the beech being met with in the woods of Hampshire, but the largest individual trees are found growing in the parks of our gentry and nobility. The Burnham beeches in Buckinghamshire are well known, the woods of Lord Grenville at Burnham containing some remarkably fine trees-a spot that has become identified with the musings of the poet Gray, whose celebrated Elegy adorns English literature.

A beech-tree which stands in Windsor Forest is said to have stood before the time of the Norman Conquest: though the beech is not reputed to be a long liver, 150 years being thought to bring it to old age, while 300 years generally witnesses its last decrepitude; when grown for the sake of its timber it is not considered profitable to retain it beyond 
the age of eighty years, still there are well-authenticated trees, of ages extending from 250 to 300 years. The rate of growth is about the same as the oak, and will succeed on most dry soils, it being considered best to grow in clumps, or masses, being naturally disposed to waste itself in spreading branches. A great many fine beech-trees are to be met with in Morayshire, in the north of Scotland, which perhaps is mainly to be attributed to the fact that the Stuart, Grant, and Fife families have been noted as treeplanters for many centuries.

When planted in sandy loam, or upon the slopes of hills that have calcareous bottoms, where there is sufficient room for expansion, its habit will partake somewhat of the nature of the birch. Its hard, spiky buds, upon the advent of warm weather, are transformed into round, silky folds, producing a soft, delicate verdure, very pleasing to the eye, affording a large amount of shade as the season progresses.

Its timber is not very valuable, though useful for many purposes, but it stands well when continually under water, and on this account is frequently resorted to in the construction of the keels of ships, for piles, flood-gates, and sluices; in France being extensively used in the manufacture of sabots, or wooden shoes, throughout the mountainous districts. Tho leaves of the beech have been frequently used for filling', mattresses instead of straw; when applied to this use, being gathered immediately after they have 
thentiyears. $\mathrm{k}$, and sidered turally es. A vith in erhaps Stuart, tree-

slopes ere is artake hard, er, are ing a eye, season

ful for nually ly res, for g exooden The d for ed to have fallen, and carefully dried before being used, when they will remain sweet for five or six years.

The climate of England does not appear to develop that unctuous secretion in the mast which is the case in France, where the oil from the nut forms an important article of commerce, the forests in the Department of the Oise having yielded, in a single season, more than twe million bushels of these nuts, the forest of Compaigne alone, in 1779, it is said, producing oil enough to supply the wants of the district for half a century.

'The beech makes a capital hedge, when trimmed close affording a great deal of shelter, particularly during the winter and spring months, in consequence of the withered leaves adhering to the stems. Between Ghent and Antwerp, it is very customary to form hedges of young beech-trees, which are planted seven or eight inches apart, so as to cross each other trellis-fashion, forming apertures about six inches in diameter. During the first year they are united with osiers at the place of intersection, where they ultimately grow together, and, not suffering when pruned, are well adapted for the purpose.

Cultivation.-The tree is raised from seed, which becomes ripe in October, and is usually obtained by spreading large sheets ronnd the bottom of the tree, and then shaking the branches violently. As there are a good many bad, or infertile seeds mixed with the good ones, they can be distinguished, and separated, by putting them all into a tub half filled with 


\section{ENGLISH TREES AND TREE-PLANTING.}

water. The good seeds will sink to the bottom, and the bad ones float on the top of the water, from whence they can be easily removed. The job, however, should be done quickly, and the good seed spread out at once to dry ; and when made perfectly free from moisture should be packed up in boxes, bags, or barr . I mixed with twice their volume, or amount, of sand.

The seed should be sown from the end of March up to the conclusion of the first week in April. The: will grow well enough if sown in autumn, but there are two dangers to which this practice would cause thein to be subjected. The depredations of mice, which search them out and eat them; and the frosts, which will generally destroy the young and tender plants, as the autumn-sown seeds will germinate in April.

The method of cultivation followed is the same as that pursued in the case of the ash, except that the nuts should be about an inch apart from one another, and be covered with an inch depth of soil. The mast should also be gently patted down with the back of a spade, to keep them in their proper position before the soil is spreal over them. The plants slould not be pruned until they are well established, for if this is done, they will become bark-bound, and refuse to grow, and this will most likely happen also if they are allowed to stand in the seed-bed for more than two years without being transplanted-an invaluable system in most cases for inducing a healthy 
growth of the young plant. Should plants become bark-bound at any time, from one cause or another, the best practice is to cut them down in April to within four inches of the ground, and choose out a straight shoot to form the future tree.

Upon many soils, the beech cannot be profitably grown, but upon a clalky subsoil, no other tree will grow so well, if we except, perhaps, the walnut.

The Elm (Ulmus), natural family Ulmacea; Pentandria dyginia of Linnæus.-There are several varieties of the elm, but there are two principal ones that occupy a very important place amongst English trees-the $U$. campestris, or English elm, and the $U$. montana, the mountain, or wych elm, or, as it it sometimes called, the wych hazel, from its resemblance to the latter tree, which is a native of Scotland, but not growing to so great a height as the English elm.

The English Elm.-The English elm is generally considered to be one of the finest, and tallest of European trees. It grows rapidly in an erect form, and yields a tall bole, which is renarkable for the uniformity of its diameter throughout. The wood has less strength than that of the oak, and is not so elastic as the ash, but is tougher, and less liable to split, being brown, hard, and of a finc grain, which, as it does not crack, is employed in the manufacture of certain articles, as blocks, pumps, cart-wheels, and for various cabinet-making purposes, as well as being extensively used for making coffins. 
The tree generally attains maturity in seventy or eighty years; after which it has a disposition to become hollow in the centre, and during heavy gales these affected trees are often blown down, making a gap in some stately avenue, perhaps leading to a country mansion; elms being often found of large dimensions and great age in the neighbourhood of old halls, cathedrals, castles, and palaces; its close habit of growth and density of foliage causing it to be a peculiarly appropriate tree for an avenue, or approach to a building of importance or architectural pretension.

Excepting the oak, perhaps, it is more commonly met with than any other tree in England, it being said that, there are upwards of forty places which derive their name from this tree. Although they are often uncertain trees, whose duration cannot be always relied on, yet in many instances they attain a venerable age, some of the old elms planted by Sully, the minister of Henry IV., still standing in France. The measurement of many very large elms growing in England has been recorded, one of the most remarkable being the Crawley elm, standing in the ligh-road between London and Brighton. When measured it was found to be sixty-one feet in circuniference at the ground, its height being seventy feet. Its trunk was perforated from the top, and it measured thirty-five feet round, inside, at two feet from the ground. In Warwickshire, a tree of 200 years old stood 150 feet in height, supposed to 
enty or

to be-

$y$ gales

king a

8 to a

f large

ood of

s close

ig it to

or ap-

ectural

monly

being

which

they

lot be

attain

ed by

ing in

e elms

of the

nding

hiton.

feet

being

e top,

two

ee of

ed to

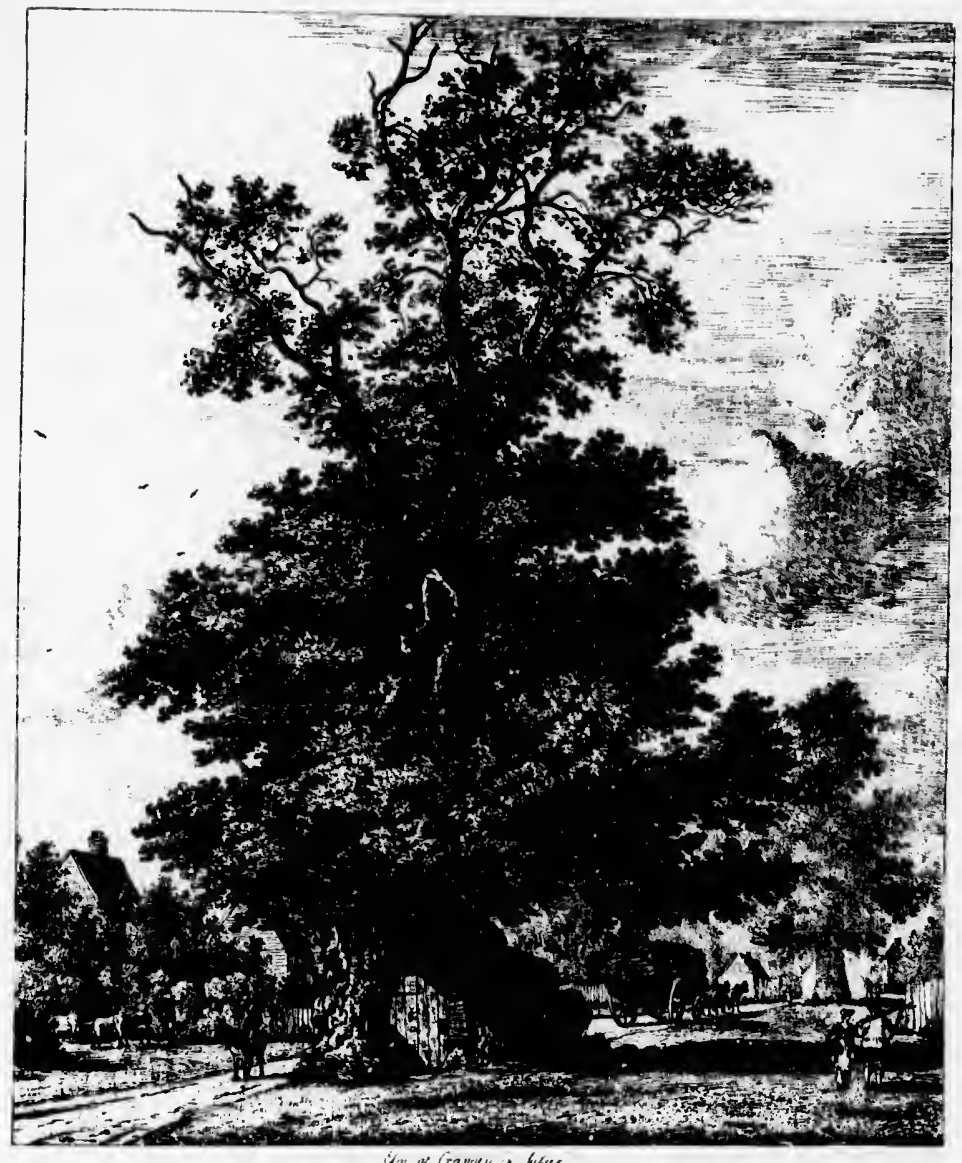

idm on tranky is kufue 


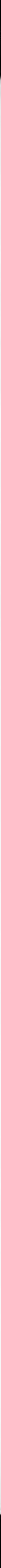


be the loftiest tree in Euglanì (a good specimen of a 'Warwickshire weed,' as these trees have been called), the diameter of its trunk being nine feet six inches; while one at Strathfieldsaye ineasures 130 feet in height. As th.e elm rarely produces seed in England, it has been questioned whether the tree is indigenous to this country, but if not, it must have been introduced at a very early age. When the seeds do ripen, the flowers appear in the beginning of March, about three weeks before the leaves inake their appearance, being small, of a reddish colour, united in clusters. They are succeeded by oval-bordered capsules, which each contain a single, round, compressed seed, which ripens in May.

It is a native of the south and niddle of Europe, and the west of Asia, and in these geographical ranges it yields seed abundantly, in France especially, a great number of trees being raised from seed.

Cultivation.-It is not usual to raise elms from seed in Great Britain, the trees being mostly propagated by layers from stools, or from suckers from old trees. The niethod of propagation by layers is the best one, a stool being formed by lopping over a plant that has become well established. During the following summer, the reot produces a number of young shoots, and when these have finished their growth for the season, they are bent downwards to the depth of five or six inches into thr earth, and fixed in the ground, leaving their extremities clear above it, in an erect position. In the course of the 
succeeding summer these layers become rooted, and another crop of young shoots is produced by the stool.

The layers should be removed any time during open weather, in either winter or spring, which will make room for the next crop of young shoots coming round, to be laid down in the same manner, the stool yielding a crop of plants every year successively, so that one stool will bring numbers of young trees, especially if it be placed in good and suitable ground for the purpose, which should consist of a sandy, rich, friable soil.

The young plants should be inserted into nursery lines for two years previously to being planted out where they are intended finally to stand. A soil of an intermediate description is best adapted for the growth of the young tree, with an open subsoil, but it will grow freely in soils of very opposite qualities to each other, as a moist clay, and a dry, sandy soil. As the young plant forms a fibrous, buslyy root, it will allow of being transplanted at a size and age above the usual average of timber trees, upon fair soils attaining a height of twenty-five feet in ten years, seldom requiring pruning, and invariably assuming an erect form. About twenty sorts are cultivated by nurserymen, and as the genus is very confused, botanists are unable to deternine which are species, and which varieties only, the tree being quite , remarkable for its propensity to produce seedling varieties, many of which are but of feeble growth, and of no value as timber trees. 
The Wych Elm (U. montana).-The mountain, or wych ehn, is of a slower growth, and yields a shorter bole than the English elm, but is more spreading in its habit, bolder in its ramifications, and altogether a more picturesque tree, its height being usually about fifty feet, but reaching a higher altitude when grown in company with other taller-growing trees. It does not yield suckers like the English elm, but produces seed freely.

The blossoms make their appearance in April just before the leaves expand, the seeds usually getting ripe about the middle of June. When water stagnates near the surface of the soil, the growth of the tree becomes enfeebled, and this is invariably attested by the presence of lichen on the bark. The timber is useful for many agricultural purposes, as the handles of spades, forks, \&c., though the wood is not considered so serviceable for general purposes as that of the common elm. At one time, at the ancient period of which we have before spoken, it used to be made into bows for archers.

Cultivation.-The seeds should be gathered when they are ripe, about the middle of June, and sown at once in rich, clean, friable soil, in beds of the usual width of four feet, a bushel of seed being sufficicnt for a bed of twelve lineal yards. The germinating power of the seed is very unequal, half of it will perhaps turn out to be infertile, so that a certain degree of judgment needs to be exercised with respect to the quantity of seed sown; the aim being to produce a 
seed-bed of plants which will stand about two inches apart. The seed should be covered with half an inch depth of soil ; in dry weather the beds require to be watered, and also shaded from the rays of the sun. As seed strike quickly at this season of the year, the plants will often make their appearance in about a week after they have been sown, when the shading is discontinued, and no further care is necessary, beyond keeping the beds clear from weeds during the summer. In the following winter, or early next spring, they can be removed into nursery lines, but wher. they have come up but thinly in the seed-bed, they are often allowed to stand there for two summers before removal. The lines should be a foot and a half asunder, and the plants stand in the lines at a distance of six inches. They are usually kept thus for two years, and if allowed to stand much longer without being disturbed, the roots are apt to get bare, so that when finally planted out, they are likely to get shooted. The tree will grow well, and yield heavy timber in a rich soil only, liking an open free subsoil, and often producing large protuberances of gnarled wood, which gives it a picturesque appearance. It is sometimes apt to ramify near the ground, which, if allowed to go on unchecked, will cause it to form only a very short trunk, when pruning may advantageously be resorted to, the best time for doing this being when the tree is from eight, to fourteen years of age. By shortening some of the shoots, and curtailing the strongest of the lateral 
aches inch to be sun. , the ut a ig is bethe lext but ed, iers d a t a Ius ger get ely ld ee of d, to $y$ branches, the trunk may by this means be lengthened, the need for doing this being chiefly when it is grown in open situations.

The Huntingdon $E \operatorname{lm}$ (U. vegeta). - This is a fastgrowing variety, that has been in cultivation for rather more than a century, and produces fine timber. It is sometimes propagated by grafting upon the wych $ı l m$, but more commonly from layers.

The Dutch Elm (U. suberosa).-The Dutch elm was brought from Holland during the reign of William of Orange, who has been twitted by succeeding generations for his affection for the formal Dutch style of gardening; this variety being much used in the trimly clipped hedges that marked that period, having large thick leaves and a fungous bark, on which account it is sometimes called the corkbarked elm.

The American Elm (U. Americana).-There are two kinds of American elms, white and red. The white has a greyish bark, deeply furrowed, while the red is of a reddish brown colour; both varieties rising to the height of what may be termed noble trees.

Variation of the Elm.-The aptitude of the elm to vary in its character when raised from seed, and its propensity for producing seedling varieties before alluded to, causes the genus to be very much confused, and it has been conjectured that the Dutch elm, which is usually classed as a separate species, is merely the common elm debased by the humid soil, 
and climate of Holland, the tree being injured by too much humidity. The difference of vigour at the same age of various trees, may often be traced to this cause, for although many elms have attained to a large size, and have been long-lived, others have been comparatively short.

An elm-tree that was planted by Henry IV. of France was standing in the Luxembourg at the commencement of the French Revolution. One wellknown tree that used to stand at the end of Church Lane, Chelsea, that was felled in 1745 , was said to have been planted by Queen Elizabeth; while Sir Francis Bacon's elms in Gray's-Inn walks, that were planted in 1600 , had fallen into a state of decay about 1720. The health of these, it is surmised, must have been injured from some cause or other, as too much moisture of the soil, or the smoky atmosphere of London. The beautiful Long Walk at Windsor was planted at the beginning of the last century, but niost of the trees have evidently passed their prime; and the most profitable age of elm-trees, both as regards the quality, and quantity of their timber, has been conjectured to be about fifty or sixty years; and there can be no doubt but that both soil and situation exercise a most material influence upon the health, and prosperity of the elm.

The Weeping Elm (U. pendula).-The weeping elm began to be cultivated about the close of the last century, and is, perhaps, the most ornamental and picturesque of the species. It seeds freely, and on 
this account has been supposed to have originated from the wych elm, plants raised from seed being very apt to lose the distinguishing characteristics of the species. It is therefore found to be the best plan to propagate the variety by grafting on the stems of a common elm, as it grows freely when managed in this way, and forms a head of considerable magnitude, which often assumes a rugged, and most diversified form when in the vigour of its youth, shooting out its branches in various directions-some horizontally, some upwards, some downwards, and others obliquely, often assuming an imposing appearance that is never met with in any other tree, resembling very much in picturesque effect the cedar. 


\author{
CHAPTER $\mathrm{X}$. \\ BROAD-LEAVED TREES-(cont.).
}

THE MAPLE-THE GREAT MAPLE OR SYCAMORE : CULTYATION-THE COMMON MAPLE-THE SUGAR MAPLE-THE NORWAY MAPLE: CULTIVATION-THE RED OR SCARLET MAPLF-TYE LARGE-LEAVFD MAPLETHE STRIPED-BAREDD MAPLE-THE PLANE TREE-THE EASTERN PLANE: CULITVATION-THE SPANISH CLANE: CULTIVATION-THE HORNBEAM : MODNT ETNA-CULTIVATION.

The Maple-natural family Acerinece; Polygamia monecia of Linnæus.-There are upwards of twenty species of hardy maple cultivated in England, which have been imported at different times from Europe, America, and India, and it is believed there are yet many hardy kinds, on the mountains of China, Japan, and India, which might, with advantage, be cultivated in this country, the whole genus being remarkably landsome-of the twenty varieties which grow in England some attaining the fill size of a timber tree, while others assume only the proportions of handsome shrubs. Some of these are remarkable for growing quickly at an early age; while others are interesting on account of their coming early into flower; others, again, are remarkable for the fine texture of their elegantly lobed leaves, which in 


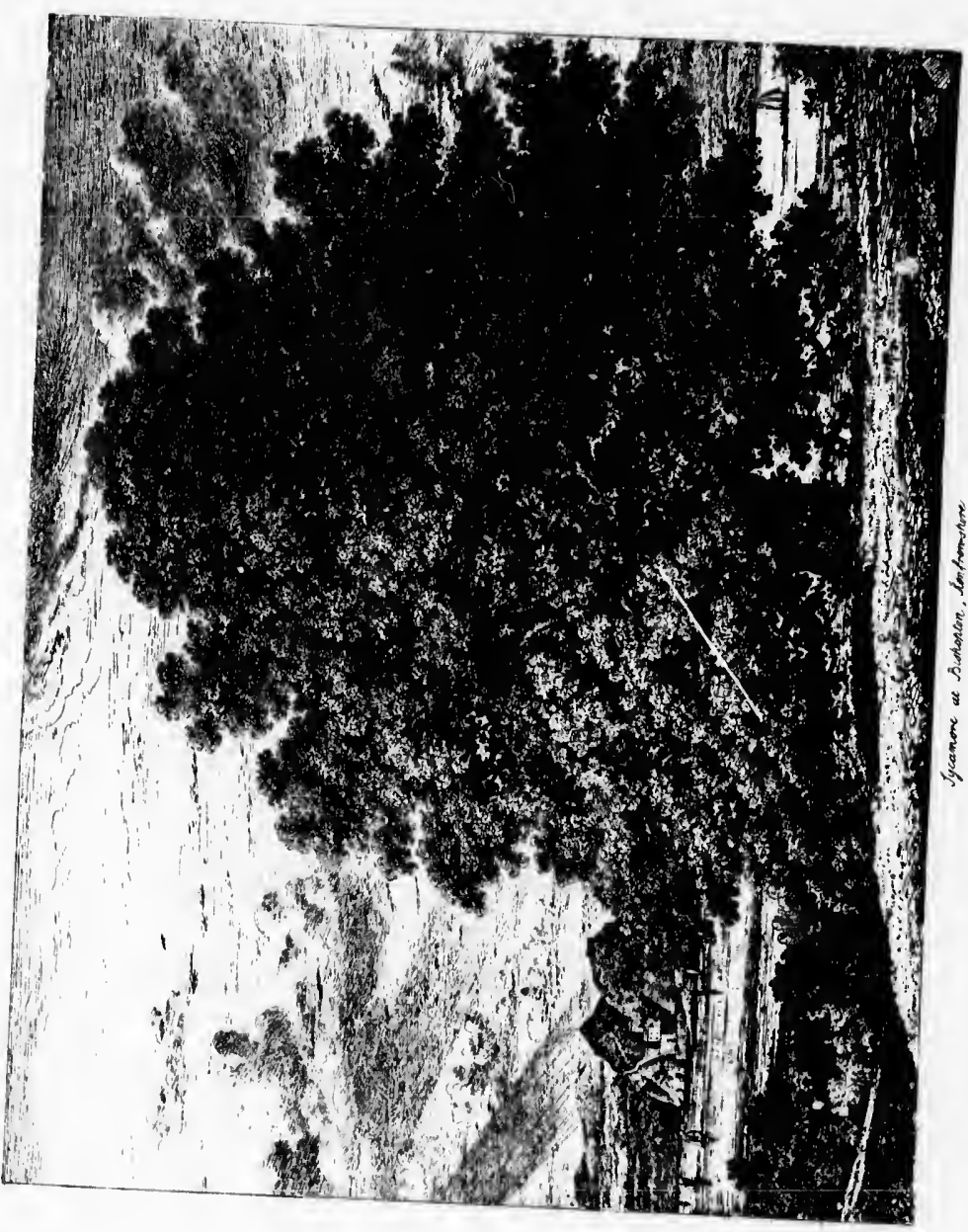



autumn change into many gay hues, and exquisite shades of yellow and scarlet, which at that season of the year give to ornamental plantations a gay, and cheerful aspect. There are, however, two principal varieties that are common to Britain: the common maple, and the mock plane-tree, or sycamore, there being a great number of varieties which are too tender to endure the climate of Britain.

The Great Maple, or Sycamore (Acer Pseudo. platanus).-The sycamore was introduced into Britain about the middle of the sixteenth century, and was amongst the earliest of our cultivated trees, being a native of Germany, Austria, Italy, and Switzerland, where it is found growing with other trees in hilly situations, being the largest, but the least ornamental, of the species. Few trees are so well adapted for standing singly in rough, and exposed situations, and it also endures the effect of sea-spray, which is injurious to most trees.

It not only attains the dimensions of a large timber tree, but is also very long-lived. Although it has been proved to demonstration that, nany trees have livel to a great age, being solnetimes marked down oll old county maps, there is a good deal of exaggeration mixed up with these accounts of venerable trees, and the sycamore is not without its specimens of recorded long life; for St. Hieron, who lived in the fourth century of the Christian era, writes that he saw the same sycamore-tree on which Zaccheus climbed up for the purpose of seeing aur Saviour 
ride by in the course of his triumphal entry into Jerusalem ; a fact which our Lord brought again to the remembrance of Zaccheus upon a subsequent occasion. The timber of the sycamore is close and compact, not liable to warp, and is, therefore, of a very useful order for the purpose of being sawn up into boards ; sometimes being of a uniform colour throughout, and at others beautifully mottled. As it takes polish well, it is often used in the latter case for musical instruments. The wood, containing none of those hard knots which are injurious to tools, and supporting the variations of heat and moisture well, is often applied to the manufacture of saddle-trees, founders' patterns, and other items of furniture and machinery; and, when such things were in use, was formerly employed for making wooden dishes, bowls, cups, plates, and other articles of domestic use, which were converted into household vessels by the turners of a bygone age, when we used to import the greater part of our crockery ware from Delpht in Holland, the use of which has now been superseded by the improved earthenware, for which we are indebted to the exertions of Wedgwood and others.

Cultivation.-The sycamore blossoms in spring, and the seeds become ripe in the following autumn, when they should be collected and mixed up in a pit, with twice their volume of sand, and sown in the succeeding spring. If sown in the autumn, when the seeds become ripe, the young plants spring up so early as seldom to escape the frosts, and are consequently often destroyed. 
ntry into again to ent occacompact, ry useful boards ; oughout, es polish usical inose hard pporting often apfounders' ichinery; erly em$\mathrm{s}$, plates, ere cona bygone $t$ of our e use of mproved le exer-

spring, autumn, in a pit, in the vhen the o up so e collse-

The seeds should be sown in beds of the usual form in a dry soil, that is, not too rich; but which should be made fine. Very fertile, or a moist soil, causes an excess of growth, so that the young plants are unable to mature their wood during the first season; and when this is the case, the frost will cut them off; but this is only likely to happen in the case of plants of one year's growth. One bushel of seed will be enough to plant a bed twenty-four feet long, of the ordinary width of four feet, and the seeds should be covered with soil half an inch deep. After standing in the seed-bed one season, they should be transplanted into nursery lines, standing two feet apart, the plants being about eight inches asunder in the lines. After standing thus for two years, they are then suitable for forest planting, and are usually from four, to six feet high.

A deep, soft, dry soil is the most congenial one to the sycamore, and in sucl, the trees will generally attain a lieight of twenty feet at the age of ten years; and sometimes in twenty years, or less, that of ferty feet; but this will only happen in soil exactly applicable to its growth, although it is a tree that will grow in land of very different qualities.

It comes into leaf early in the season; in the month of May its foliage presenting a bright green, and lively appearance; but on account of its leaves exuding a glutinous substance, it is not a good tree to plant by the roadside, as the dust, and every other impurity borne along by the wind, adlieres to them; 


\section{ENGLISH TREES AND TREE-PLANTING.}

and as the foliage thus becomes dingy, it loses what natural attractiveness it possesses.

The Common Maple (A. campestris).-This is a smaller tree than the sycamore, having smaller-sized leaves, which are cordate and fine-lobed. The flower-buds begin to open about the commencement of April, and the leaves come out about the middle of the same month, or a little later, in the first fortnight of May the flowers being in full bloom.

Although of smaller size, the timber of this tree is superior to that of the great maple, or sycamore, much of it being curiously marked, and passing under the name of 'Bird's-eye Maple,' and is extensively used for picture frames, and by cabinet-makers. It was noticed by the ancients, Pliny extolling the wood of the maples growing in different parts of the world for the fineness of their grain ; while Virgil describes Evander as sitting upon a maple throne.

At one time the demand was so great for the finest specimens of curiously marked wood, when to be obtained in boards sufficiently large for the formation of tables, and large articles of furniture, that extravagant prices were obtained for them. One writer says that, in ancient times so great was the appreciation for curious portions of the wood, that in its veined aspect often formed the effigies of birds and various animals, that one table is said to have been purchased for ten hundred thousand sesterces, and another is spoken of that cost upwards of fifteen hundred thousand! 
ses what

This is a ller-sized d. The encement e middle irst fort-

this tree ycamore, ag under tensively kers. It he wood he world lescribes

for the when to for the arniture, $r$ them. reat was ood, that of birds to have esterces, f fifteen

The Sugar Maple (A. saccharinum).-This tree was introduced into Britain about the middle of the last century, but in this country it seldom reaches a height above that of forty feet, though in its native districts it often atiains an altitude of from sixty to seventy feet; though the diameter of its trunk is very small in proportion to its height, generally varying from twelve to eighteen inches.

It grows in great abundance in Canada, Nova Scotia, New Brunswick, the States of Vermont and New Hampshire, the upper parts of Pennsylvania, and the district of Maine, Genesee, and New York. In the middle and southern states of the Union it is almost unknown; flourishing best in the mountanious districts where the soil is cold and moist, but fertile; growing along the whole of the chain of the Alleghany Mountains.

In its native habitat, it is chiefly prized for the juice which it exudes, which is converted into sugar by a very simple process. Sugar has been extracted from maple-trees in this country, and numerous samples of maple sugar were shown at the great Exhibition of 1851, when several prizes were awarded for it; but it is not believed that, in this country, it can be profitably cultivated; though it is notorious that the English farmer is dreadfully backward in all matters that relate to what may be termed agricultural manufactures.

In America, the sugar is esteemed to be of excellent quality, but little inferior to that of the 


\section{ENGLISH TREES AND TREF-PLANTING.}

sugar-cane. The sugar is commenced to be obtained in February, or the beginning of March, when the cold is often intense and the ground covered with snow, when the sap commences to rise, or about two months before the general revival of vegetation after the torpor of winter. The trees are perforated by an auger, three quarters of an inch in diameter, in an obliquely ascending direction, about a foot and a half from the ground, and sometimes a little more; two holes being made about five inches asunder; care being taken that the auger does not penetrate the tree more than half an inch within the wood, experience having shown that the most abundant flow of sap takes place at that depth. Small troughs to receive the sap are made out of elder, or sumach, eight or ten inches in length, to correspond with the size of the auger, which are laid open for a part of their length; the sap being conveyed into deposit troughs. One of these is placed on the ground at the foot of each tree, and the sap is every day collected, and temporarily poured into casks, from whence it is drawn out to fill boilers of a capacity of about eighteen gallons. The evaporation is kept up by a brisk fire, and the scum carefully skimmed off. Fresh sap is continually added, and the heat maintained till the liquid is reduced to a syrup; after which it is left to cool, and ultimately strained through a blanket, or other woollen material, to separate the extraneous particles; moulds are prepared to receive the syrup when reduced to a proper 
obtained vhen the red with jout two ion after ed by an $r$, in an id a half re ; two er; care rate the experiflow of ughs to sumach, with the part of deposit ound at ery day s, from acity of kept up ned off. it main; after trained rial, to re preproper consistency for being formed into cakes; the process of evaporation being known to have proceeded far enough when, upon rubbing a little of the syrup, between the fingers, it is shown to be granular. When the heat gets occasionally excessive, and there is danger of its boiling over, a small piece of butter or lard thrown into the boiler immediately calms down the ebullition. The molasses is drained off the moulds, and the sugar is then fit for use, its taste being as pleasant and as useful for culinary purposes as the ordinary West India sugar; but its use is, however, chiefly confined to the districts where it is produced, maple sugar being inade in the greatest quantities in the United States, in the upper part of New Hampshire, in Vermont, and the State of New York, and other parts; the farmers, after laying aside a sufficient quantity for their own use, sell the remainder to the shopkeepers in the small towns adjacent to them, who give them eight cents. per pound for it, and retail it to their customers at eleven cents. A good deal of maple sugar is also made in Upper Canada, in Nova Scotia, and the district of Maine.

The Norway Maple (Acer platanoides). - This tree attains to a great size, and is quite hardy, its leaves being large, like those of the sycamore, and containing a bitter, milky juice, which prevents their being preyed on by insects; they are of a bright green colour. The rapidity of its growth exceeds that of the sycamore, when young, though 
it does not ultimately attain the dimensions of the latter.

It grows freely on the mountainous districts of Northern Europe, in some parts of Norway descending to the sea-shore, abounding in the North of Poland and Iithuania, and is, as well, common throughout Germany, Switzerland, and Savoy. The leaves assume a golden colonr in autumn, which causes it to be a very ornamental tree, while in spring its full, yellow blossoms give to it a very handsome appearance.

Cultivation.-The Norway maple is propagated in the same way as the sycamore, preferring a deep, well-drained soil, the species including several varieties, amongst the most remarkable of which is the Cut-leaved, or Eagle's-claw Maple, which is very ornamental, and easily propagated by buds, or grafts upon the stock of the common sycamore.

The Red or Scarlet Maple (A. rubrum). - This is a pleasing variety, which produces red blossoms late in spring, or carly in summer. It is a low-growing tree, a native of North America, and is difficult to raise from seed, and is, therefore, generally propagated by layers. It does best in a rich soil, and bears moisture better than any other species, succeeding in wet and swampy situations. It sometimes produces very valuable timber when it is old, owing to the beautiful graining of the wood.

The Large-leaved Mrsple;A. macrophyllum)._This variety is also a sative of North Anerica, being 
of the

tricts of escendorth of ominon r. The which spring ndsome

agated deep, varieis the $s$ very grafts

his is a late in g tree, raise ted by oisture et and very autiful L'This being

hardy, of rapid growth, and often attaining a great size. It was introduced into Britain in 1812, and often yields timber of a very ornamental description. The Striped-Barked, or Snake-Barked Maple (Acer striatum). -This tree is very ornamental at all seasons, having a slender stem, with a smooth bark, that is beautifully varied with green and white stripes, as well as black and white stripes; the boughs being of a shining red in winter. It is a native of North America, and although sometines propagated from imported seeds, it is morc commonly grafted upon stocks of the sycanore. It is a capital tree for ornamental plantations, supplying a thick shade, and its wood is esteemed by the cabinet-maker.

There are several other species of maple, as $A$. villosnum, a hardy tree imported from the Himalayas, which attains a great size, and resembles in appearance the sycamore; $A$. circinatum, also a hardy tree from Oregon, where it grows to a height varying from twenty, to forty feet, forming impenetrable thickets. Its pendulous branches yield leaves which surpass the brilliancy of the finest scarlet oaks in autumn, and it is on this account a highly decorative tree to blend with others of a more sober description of foliage.

The Plane-tree (Platanus), natural order Platanacee; Monsecic nolyandria, of the Linnaan system. -This tree is entirely different from the Acer Pseudoplatanus, the mock plane, great maple, or sycamore, which is popularly called the plane in North Britain, the genus comprehending only two species, the 
Eastern and Western plane, which are cultivated in Britain only as ornamental trees, there being nowe, perhaps, which offers more handsome foliage than the plane, which is generally considered to excel in beauty all the other broad-leaved deciduous trees that have become acclimatised in this country. The great drawback to their cultivation is that in early spring a change of weather, when frost supervenes, is likely to destroy the leaves immediately after the expansion of the buds; and, unless upon an early soil, and in a warm situation, an ordinary English summer is not of sufficiently long duration to enable it to mature its young wood, so as to endure the frosts of winter.

The seeds of the plane are formed in round balls, which are suspended from the branches by slender thread-like stalks, which form an attractive feature at all seasons of the year. In their native countries both species attain to a very large size, and even in England, in warm situations, and under circumstances favourable to their growth, they are unsurpassed by the finest of our native trees.

The Eastern Plane (P. orientalis).-This species is commonly net with on the banks of the rivulets in Greece, the East of Europe generally, and on the coast of Asia Minor, and was introduced about the middle of the sixteentl century into Britain. The Groves of Academus, in which Plato delivered his discourses, were formed of the plane-tree, as well as the Groves of Epicurus. The shady walks planted near the Gymnasium, around the schools of Athens, 
ated in g none, han the xcel in ees that e great spring likely ansion ad in a not of . ure its er.

balls, lender eature intries en in ances ed by cies is ts in a the t the The his ell as inted 1ens,

and other public buildings, were all formed of the plane; the enthusiasm of the Greeks and Romans, it is said, having been more excited in the cultivation of this tree than of any other. According to Herodotus and Alian, when Xerxes invaded Greece, he was so much struck with the appearance of a beautiful plane-tree in Lycia, that he caused it to be encircled with a collar of gold, and adorned it with jewels in a lavish manner, and confining it to the charge of one of the Ten Thousand, caused an effigy to be struck of it upon a gold medal, and by causing his whole army to encamp in its neighbourhood for days, by such means occasioned such delay as led to his defeat. On the banks of the Bosphorus some enormous plane-trees are to be seen, one particular tree in the meadow of Buynkdere being described by travellers as having a trunk which presents the appearance of seven or eight trees, which springs, as it were, from a formation like that of a stool that has been lopped over; some of the trunks proceeding from the surface, while others branch out at a height of seven or eight feet; the circumference at the base being $\mathbf{i} 41$ feet, the diameter of its branches being 130 feet, which, if regarded as a single tree, would probably be one of the largest in Europe or Asia, De Candolle conjecturing it to be 2,000 years old.

In Britain, it will attain a height of seventy, or eighty feet in fivourable situations, and is generally of rapid growth in positions best adapted for its 
existence. Its branches range horizontally, and contain large masses of foliage, which, while by their arrangement are favourable to the admission of air, yet exclude both rain and sunshine; while its large leaves are easily set in motion by the passing breeze ; its foliage, perhaps, being of a brighter green than almost any other tree of a large size. The leaves are five-lobed and palmate, and on healthy young shoots they are often ten inches long and twelve inches broad, but upon the old trees are only about half these dimensions.

Cultivation.-It blossoms in May, and in favourable seasons will ripen its seeds in October. The round balls whicl contain the seed should be broken, and the seed sifted, in order to separate them from the cottony fibre with which they are mixed, and sown in March. A very sliglit covering of soil is sufficient for them, but they should be pressed into the surface of the ground so as to be held firmly in their places and kept moist; for which purpose a light covering of branches of evergreens will be appropriate. A quicker way, however, is to propagate by layers in the manner that has been before described by lopping over a stool. It grows quickly, young plants being often four or five feet ligh when only one year transplanted from layers. A deep, rich, soft soil is necessary for them; and it has been found that, where trees have attained a very large size, their roots have had access to water. It wants shelter, without confinement; succeeding best in 
l contheir f air, large eeze ; than es are hoots nclies half

vour-

The

okell, from and il is into rmly pose ll be profore kly, rhen rich, und size, ants in alluvial soils, along valleys, near the banks of streams, where it will put on its best appearance.

The Western Plane ( $P$. occidentalis).-The western plane was introduced into Britain about 1630 , being a native of North America, commonly found in the fertile valleys on the banks of the Ohio and its tributary streams, as well as by the side of the great rivers of Pennsylvania and Virginia.

It resembles very much the Oriental species in its general appearance, its leaves being large, lobed, and somewhat downy underneath, while the seed-balls are smoother than those of the Eastern plane. It is very susceptible to frost, yet the best specimens to be seen in this country belong to this species, though it is a less hardy tree than the other: growing with great rapidity, its young shoots seldom become matured to their extremities, and, consequently, they die back to some extent from the effects of frost ; in cold weather, in May, assuming a scorched \& pearance, but upon the advent of continued fine weather in course of the summer, it gradually assumes a rich clothing of green, which causes it to be one of the handsomest of park ornaments.

Cultivation.-The Western plane may be readily propagated from cuttings, but it is more commonly grown from layers, the plan pursued in its cultivation being the same as that recommended for the other species, and it frequenily attains a height of thirty feet in from fifteen, to eighteen years. One tree, which was planted at Lambeth Palace, whose roots had 
access to a pond, reached the extraordinary height of eighty feet in twenty years; one of the tallest of the species being in Chelsea Hospital Garden, about 115 feet high. Its roots extend towards the Thames, which doubtless explains the cause of this somewhat unusual vigour, so successfully emulated upon the opposite side of the river.

The Hornbeam (Carpinus), Natural order Amentacea, Monscia polyandria of Linnæus.-.There are three or four species of Hornbeam, all of which are deciduous trees, its leaves bearing a very close resemviance to those of the beech, being often called the 'horse-beech' on this account by country people. The common hornbean, $C$. betula, is a tree that thrives on cold, barren, and exposed hills, in situations where few deciduous trees will succeed; and on this account is well worthy of being cultivated to a greater extent than is the case in Britain, receiving less notice, perhaps, at the liands of tree-planters than almost any other liardy tree adapted to the climate of Britain. Its appearance is that of a tree somewhat between a beech and an elm, its leaves being destitute of that bright polish which characterises the beech; in magnitude standing between the latter and the birch, but is neither valuable for timber nor as an ornamental tree, its chief recommendation being that it is by no means of slow growth; and resisting the violence of the winds better than most trees, it is calculated to afford good shelter. The leaves resemble those of the heech in hanging on the branches till the 
ight of of the ut 115 hames, lewhat on the

Amen-

re are

h are cesemad the eople. that situand on to a aiving than ate of what itute ech ; the is an that the calnble the

young buds push them off in spring, which causes it to be a good hedge plant, and, as well, it endures pruning better, and is less subject to disease and atmospheric blight, when grown in a confined form. As a hedge plant, it is also superior to beech in being less injurious to neighbouring crops, its roots deriving sustenance at a greater distance from the surface.

It succeels well on common kinds of soil, and grows quickly on cold clay, according to Miller, reaching seventy feet in height, with a large round stem, periectly straight and sound when upon a stiff clay, which appears to be its natural soil. Its ordinary height is, however, considerably less than this, the trunks being often flat and of an irregular figure. It readily springs when lopped over at the surface, or at any height from the root, and is a native of England, Ireland, the South of Scotland, and many parts of central Europe, avoiding temperatures of either extreme, heat or cold.

Its wood is white, tougl, and durable; and has been extensively used in the manufacture of minor articles, particularly those in agricultural use, as handles for tools, yokes for cattle, wheelwright work, milk vessels, and for other kinds of rural adaptation. Evelyn recommends it for milk vessels, but since his day, glazed earthenware, blocked tin, and glass milk dishes for the dairy have been extensively resorted to, while Linneus observed that it is harder than hawthorn, and capable of supporting great weights, which Loudon confirms by giving a detailed account 
of comparative experiments made with respect to its powers of resistance against other wood.

Cultivation.-The seeds of the hornbeam are formed in a small nut, which usually ripens by the end of autumn. If they are planted immediately upon becoming ripe, they spring up irregularly, a few making their appearance during the first spring, but the principal part of the crop during the second year. It is, therefore, considered the better practice to sow them in spring, covering them with half an inch depth of soil, the seeds then remaining dormant for the first year after they have been sown, making their appearance in the following spring.

The beds should be formed of the common width of four feet, which is found the most convenient width for a seed-bed, one bushel of seed being sufficient to plant a bed fifty yards long. If the crop rises thickly, the young plants should be thinned out, and transplanted when a year old. If they come up thin, however, and have sufficient space to stand in the bed as two-year-old seedlings, it is usual to allow them to remain in the bed. They sliould then be lifted, and the ends of their roots pruned off, and afterwards be transplanted into nursery lines, about a foot and a half apart, the plants standing in the lines a few inches asunder.

After they have stood thus in nursery lines for two years, the plants are usually fit for hedges, but if they are allowed to remain longer without transplantation, and a greater space is allowed them, they 
m are by the diately arly, a spring, second ractice ralf an ormant making

width renient suffie crop hinned y come stand ual to then $\mathrm{ff}$, and about in the es for s, but trans, they

are likely to become tall, and bare near the surface, which will unfit them for being good hedge plants, until they are cut down near the ground to make them grow bushy. While standing in nursery lines, it is only necessary to keep the beds clear of weeds, the plants being very hardy and requiring no other attention.

The other species of the hornbeam, as $C$. orientalis and $C$. Americana, do not attain the dimensions of a timber tree in this country, but the latter is a common one in the United States and the warmer parts of Canada. The trunk, like that of the European species, being obliquely and irregularly fluted, the bark smooth and spotted with white; the fertile flowers hanging in long pendulous leafy aments, the scales of the leaves which surround them containing at their base a hard, oval seed, which always fructifies abundantly.

The Spanish Chesnut (Castanea vesca).-The sweet, or Spanish, chesnut, called sweet to distinguish it from the horse-chesnut, the fruit of which is bitter, is a splendid tree when seen at its best-growing to a great size, and enduring for ages. It is said to derive its name from Kastanea, a city in Pontus, in Asia, by general reputation being considered to be a native of Asia, as it is there found in many inaccessible situations where it could not well have been artificially planted. Report accredits the Emperor Tiberius with bringing it from Asia Minor to Europe, it soon spreading over the warmer parts of this 
continent, being found as a native tree very abundantly in the mountainous districts of southern Europe, as well as in North America, from New York to California.

It has acquired the name of 'Spanish' on acconnt of the best chesnuts, which are used as an addition to dessert, being imported from Spain, though there are numerous varieties of the chesnut to be found, especially in the south of France and Italy. In some provinces of France, as well as in Corsica, the fruit of the chesnut-tree constitutes no inconsiderable portion of the food of the peasantry. In Limousin, a province of France, where the chesnut-trees are very abundant, the inhabitants have from time immemorial prepared them in a peculiar manner, which fits them for being converted into bread. In England the fruit that is grown is very inferior to that produced in the south of France and Spain, in some of the colder districts of Great Britain not ripening at all; but in Devonshire there are some varieties which ripen their fruit earlier than others.

It has been thought probable that, the tree was introduced into Britain by the Romans, and it is now one of the most ornamental of English trees, the dianeter of the trunk being generally in proportion to that of the head, its leaves being broad and long, veined and serrated, of a dark glossy green, which change into a mellow yellow in autumn. As a park, or lawn tree, it is more tender than the oak, nor does it arrive at an equal height, or diameter, though a 
ry abun-

southern

rom New

n account addition igh there be found, In some the fruit able porLimousin, trees are om time manner, read. In ferior to Spain, in itain not are some others.

tree was it is now rees, the coportion ind long, II, which s a park, nor does hough a valuable tree for grouping and picturesqne effect; nor is the timber so valuable as that of the oak, except for certain puryoses.

One of the largest chesnut-trees in the world stands, or used to stand, upon Monnt Etna. Kircher, about the year 1670, asserts that an entire flock of sheep might be contained within its hollow trunk as in a fold, M. Houel, in his Voyage en sicile, finding it in a state of decay when he visited it, having lost the greater part of its branches, and the trunk being quite hollow. A house had been arranged in its interior, in which a family were living; an oven laving been fixed up in it, in which, according to the custom of the country, they dried their chesnuts, filberts, and other fruits which they wished to prescrve for use during winter; but they had so little respect for the tree itself, which gave them shelter, that, when they could get no other, they used it as fiel; cutting out pieces as they needed them from the interior of the tree.

Large Chesmut tree in Mount Etna.-Brydone, the traveller, gives a full account of this celebrated tree in his tour through Sicily in $17 \%$. It has been published several times before, but the particulars are worthy of being again given, for symptoms of decay oft show themselves in chesult-trees of little more than a century old, which ought indeed to lie taken as an evidence of unsuitable suil, or situation, rath than a proof of the chesnut being not a long-lived tree. The following is the account he furnishes:- 
'From this place it is not less than five or six miles to the great chesnut-trees, through forests growing out of the lava, in several places almost impassable. Of these trees there are many of an enormous size; but the Castagno di cento cavelli (chesnut of the hundred horses) is by much the most celebrated. I have even found it marked in an old map of Sicily, published nearly 100 years ago; and in all the maps of Etna and its environs it makes a very conspicuous figure. I own I was by no means struck with its appearance, as it does not seem to be one tree, but a bush of five large trees growing together. We complained to our guides of the imposition, when they unanimously assured us that, by the universal tradition and even testimony of the country, all these were once united in one stem; that their grandfathers remembered this, when it was looked upon as the glory of the forest, and visited from all quarters; that for many years past it had been reduced to the venerable ruin we beheld. We began to examine it with more attention, and found that there is an appearance that these five trees were once united in one. The opening in the middle is at present prodigious, and it does, indeed, require faith to believe that so vast a space was once occupied by solid timber. But there is no appearance of bark on the inside or any of the stumps, nor on the sides that are opposite to one another. Mr. Glover and I measured it separately, and brought it to exactly the 
five or six gh forests ces almost any of an nto cavelli $h$ the most ked in an years ago; nvirons it wn I was ice, as it sh of five omplained ey unanitradition hese were andfathers on as the quarters ; ced to the examine lere is an ce united t present faith to cupied by f bark on sides that er and I xactly the same size-viz. two hundred and four feet round. If this was once united in one solid stem, it must with justice indeed have been looked upon as a very wonderful phenomenon in the vegetable world, and deservedly styled the glory of the forest. I have since been told by the Canonico Recupero, an ingenious ecclesiastic of this place, that he was at the expense of carrying up peasants with tools to dig round the Castayno di cento cavelli, and he assures me, upon his honour, that he found all those stems united below ground in one root. I alleged that so extraordinary an object must have been celebrated by many of their writers; he told me that it had, and produced several examples.'

In England the oldest example of the chesnut tree is found in the Great Chesnut of Tortworth, in Gloucestershire, which in 1150 was styled the 'Great Old Chesnut Tree.' It stands on a soft, loamy, clay soil, in a north-west declivity of a hill, and is said by Evelyn to have been remarkable for its magnitude in the reign of King Stephen (1135), being then called the Great Chesnut of Tortworth. In 1720 it measured fifty-one feet, but Lysons, in 1791, made it only forty-five feet three inches; while Strutt, in his Sylva Britannica, in 1820, gives its measurement at five feet from the ground, to be fifty-two feet in circumference, and its cubical contents, in accordance with the usual method followed in the measurement of timber, to be 1,965 feet. It bore fruit plentifully in 1788 ; tradition carrying its origin as far back as 
the days of the Saxon Egbert. Compared with the age of these venerable trees, the duration of the period of man's life seems only as a span.

Another tree has also been described as standing in Gloucestershire, in whose hollows 'was a pretty wainscoted room properly furnished with windows and seats'; while Grose describes one of four chesnuts that stood in the garden at Great Cranford Park, Dorset, that measured thirty-seven feet in circumference, which, though shattered and decayed, still bore good crops of fruit.

The chesnut succeeds best in a deep, sandy loam, or a rich gravelly soil, with an open, and dry subsoil. So situated, its progress during the first eight or ten years of its life, after being planted out from nursery lines, will be about three feet annually; in close plantations, in a mild climate, growing with an uprigh trunk to the height of fifty or sixty feet. On exposed situations, however, on retentive and wet subsoils, its growth becomes more stunted, and it is seldom able to ripen its shoots sufficiently to resist frost.

The value of chesnut timber deteriorates after sixty years of age, the wood being of a better quality when young than in its more advanced age, a circumstance the direct opposite to the case of most trees. The vaiue of the young wood consists in the sap, or outer wood, soon changing into heart-wood, which causes it to be valuable for such purposes as posts, fences, or any other application for insertion into the 
ith the of the

anding pretty indows ir chesd Park, ircumed, still y loam, subsoil. or ten nursery $n$ close an up-

et. On nd wet nd it is o resist

es after quality circumit trees. sap, or which s posts, nto the

ground, or when it is alternately exposed to wet and dry influences, which proves very trying to many descriptions of timber. This fact has been illustrated in an account contained in the Transactions of the Society of Arts for 1769, with respect to the comparative durability of oak and chesnut when used for posts. Some posts of chesnut, and others of oak, had been used at Wellington, in Somersetshire, previous to the year 1745 . When undergoing repair, abuut 1763 , the chesnut posts were found to be very little worn, while the oak ones were quite unserviceable. It is by the recording of such facts as these, that the true value, or worth of certain kinds of timber for special purposes, is determined, and in the instance quoted, the worn-out oak posts were replaced by new ones of the same material, and the old chesnut ones allowed to stand. In twenty-five years afterwards (1788), the chesnut posts, which had stood twice as long as the oak ones, were found to be in much better condition than the latter. Again, in 1772, a fence was made partly of oak posts and rails, and partly of chesnut, the trees made use of being the same age. In nineteen years the oak posts had lecayed so much at the surface as to need strengthening by spurs, while the chesnut required no support of the kind. A gate post of chesnut, on which a gate had swung for fifty-two years, was found to be perfectly sound when taken up, and other instances are furnished of the same character, but we have quoted sufficient to illustrate the superior quality of 
chesnut timber for the purpose of these, and similar applications.

On the other hand, aged chesnut timber is apt to become brittle and shaky; the annual layers dividing from one another, and having a tendency to fall into laths; and to be had at its best for many purposes, it should be felled before the trunks attain dimensions exceeding a foot in diameter.

Cultivation. - The nuts or seeds of the chesnnt are frequently sown in October and November, preference being given to the best English seed that can be procured, as foreign nuts are often kiln-dried to fit them for travelling in packages, and their vitality cannot be depended upon, the young plants rising in April. But as at that tine of the year they are likely to receive injury from fiost, another practice is, to preserve the seeds during winter, and sow them early in spring. The plants by this means are delayed, and do not make their appearance before the middle or end of May, when they are more likely to be exempt from injury on this score. The seed is sown in drills a foot and a half asunder, standing in the rows three inches apart, and in a seed bed four feet wide, one bushel of seed is sufficient for a bed thirty yards long. The seeds require to be covered with an inch depth of soil, an early and dry one being the best for the purpose, for if planted in a late soil, the growth of the plants is likely to be delayed till late in the season, when there will not be sufficient time for them to mature their wood-a point of considerable im- 
$r$ the th of

portance-for if they lose their tops from the influence of frost they will subsequently become branchy. The plants will bear transplantation into nursery lines at one year, but are better when moved at two years of age; and when they are lifted, as the size of the plants vary, they should be classed in two lots, and have the bottoms of their tap roots cut off. In standing in the nursery lines, too great a space must not be allowed them, for, if so, they are likely to become branchy, when they will need to be pruned, a foot and a half between the rows being space enough to allow them to grow in. After being transplanted for two years, the young trees will generally be from two, to three feet high ; and if required to be of larger size, they must be transplanted every second year, increasing the space between the lines and the plants. Any time between October and March is a fit period for their removal into the situation they are intended permanently to occupy. There are several varieties of the chesnut which are cultivated for ornamentation as well as for fruit-bearing, as $C$. variegata, which is variegated with yellow and white streaks ; $C$. Americana, which has broader leaves than C. vesca, and also C. glabra; C.glauca ; and C. asplenifolia. As, however, the seeds of different varieties cannot always be relied upon to reproduce the same true description, it is the better plan to propagate them by grafting. The species krown in France as Les marrons are large and sweet, and when roasted emit a kind of aromatic odour. 


\section{CHAPTER XI. \\ BROAD-LLAYED TRELS-(rontimued).}

THE BRCH-THE COMMON BRCL : CULTIVATION-THE WUPPA BRCHTHE MAHOGANY HIRCH-THW DWARE BIRCI-THE WALUT: CULTIV'TION-THE HLACK VIRGINIAN WALNUT-THE LOCUS'T TRHE: CULTIVTHON-THW YOCUST TREE OF SCRIITURE.

Tue Bricu. - The birch is a very hardy tree, only one or two specimens of other trees ever being found so far north; and is indigenous throughout the northern districts of Europe, as well as in high situations in the South of Europe. $\Lambda t$ the island of Hammerfest, in lat. $79^{\circ} 43^{\prime}$, the dwarf birch in the sheltered hollows which lie between the momtains, not exceeding six feet in height, creeps along the ground, and in its low branches the ptarmigan finds a summer shelter, and breeds in security; the birch being a native of cold, and inhospitable climates, and almost the last tree that is found as snow is approached in elevated regions near the North Pole.

It belongs to the natural family Amentacea ; Monocia triandria of Limneus, there being two varieties, natives of Britain, Betula alba, the common birch, and $B$. a. pendula, the latter being by far the most valuable and ornamental. The common birch, when 
it grows wild, rises about thirty feet, and the weeping variety about forty feet, but both sorts attain a much greater height when formed into plantations, there being some very fine weeping birches which stand on the banks of the Findhorn, near Forres, in Morayshire, which are sixty fect in heiglit, having trunks two feet in dimneter. When the bireh attains a considerahle size, and the branches hang down sometimes thirty feet in length, as they are extremely slender, they present, a very beantifil appearance. Coleridge dubbed the weeping birch 'the lady of the woods.' The birch is often found forming extensive coppice in rocky elevations, not associated witl any other tree, and may be seen standing in gglens and ravines, adorning the margins of lakes and strears.

The Common Birch.-This tree will aceommodate itself to a wider geographical range than any other plant, and is considered to form a geod eover, and be well adlapted for snceeding Scotch pine, when timber of that description has been felled. The exuvia of the Scotch pine is very lostile to other plants, but appears to be favourable to the growth of the birch, which commonly springs up, and becomes its natural snecessor, in places formerly occupied by the Seoteh pine. Not so very long ago, in the Highlands of Seotland, the bireh was the universal tree applied by the peasantry to almost every purpose, making their bnis, chairs, tables, spoons, \&c., from it, as well as ropes and other articles; birch ropes being far more durable than ropes eomposed of hemp. 
It has beren said that, the Mighlunder in those districts where pine wood is not to be hand, lialls back 11 pon the birch for everything. 'The strongere branchess form the rafters of his rabion, his spate, his plongh, his cont (if ho hare once), and his hameness, as well as

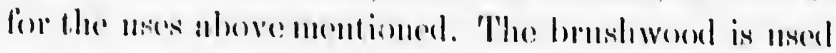
in llar formation of wieker fencess for preventing the

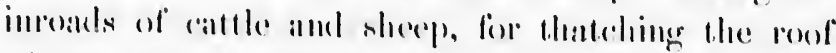

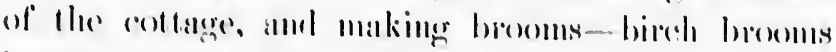

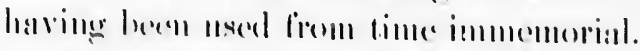

A weak, hut not moplensant wine and bo abtained by draning the sap in Marrh; boiling, and then formenting it. It is said that during the sienge of

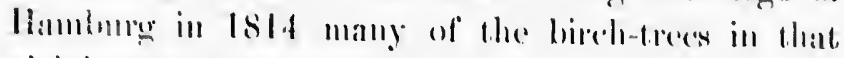
virinity wore destrogerl in this mamuce by the linssian

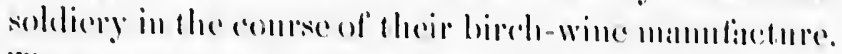
The tres at times produces beamtifnlly marked timber, mathled and reined, which is eapalble of talking a rerg high polish, while its bark is one of the most incorruptible of regotable substances, being nocel for tamning: and it is salid that, fish entel the nets of tishermen more realily tham when they hatre been preserved ly my other material, giving them an dereree of softiness and clesticity that is to be obtained hy no ofled me:ms. On the banks of the Ganry, in Cilengurry, the wood of the birelh is langely used in the manufueture of herring barrels, and it is a capital wook for the nse of the tnrmer, being light, compact, and easily worked.

As woll as for tamning, the bark is used in the 
disi1)(1) rehies mglis, :11: 1, niserl if the roof (n)tis iined then te of thist ssiatu tiure. sher, ig : most fior s of beent 11 it. be the gely it is ghit, the

preparation of simple dyes, and in Russia the hides which are so highly esteened for binding books are prepared with empyrematic oil of the birch, which confers the anreablo perfune that accompanies 'Russia-leather,' 'llhe roots of the birch-tree possess snch extraordinary powers of penetration, that, growing upon rocks which appear to the eye almost bare, with an insufficient covering of soil even for the greswth of small plants, such is their power that, piereing throngh lissmres by gradnal and snceessive eflorts, they will separate stones several tons in weight to reach the soil.

Cultivation.-The seeds of the birch usually get ripe in September, when tirey are collected, and to prevent formentation they are spread ont thinly and dried, in orrler to permit of their being kept till the following March, when they are sown. A friable, samdly, peat soil is the one best adapted for their growth; and the beds should be formed four feet broad, with an alley of one foot between them. After being smootlly ling over, îhe seeds should be spread recrintarly on the surface, and chosely pressed down with the feet in dry weather. One buslsel of seed is suflicient for a bed of thirty lineal yards. If drought prevail in May and June, the beds should he shaded with branches of evergreens. Plants of a year old will generally be about a foot high, when they should be transplanted into lines one foot apart, the plonts standing three or four inches asunder in the lines, where, after remaining for two years, they 
will generally be from two to three feet high, and be fit for planting out. The birch is a capital nurse for timber trees of a different variety, as the oak, chesnut, \&c., and reaches matnrity at various ages according to sitnation and soil, but seldom increasing after it is seventy years old. At a great elevation, it assmmes a dwarf habit, when the wood becomes much more durable and solid than in its ordinary condition, being of a light colour, shaded with red, the quality of its grain being intermediate between coarse and fine.

The Weeping Birch.-B. pendula, or the weeping birch, is the most beautiful tree of this fannily, growing alike in mountainons situations as well as in bogs, being found in the wide geographical range included between the sub-alpine districts of Italy and Asia, and Lapland.

The Mahogamy Birch.-B. lenta, or the cherry birch of Canada, is common in the middle states of Pennsylvania, New York, and the Jerseys, but is not met with in the higher latitules of the more northern states of the Union. It grows rapidly and produces beantifnlly variegated, close-grained timber, the leaves, which appear early in spring, possessing an aromatic fragrance which they retain for a long time after being dried in a stove; and althongh up to the present it has been very little resorted to, it is a very suitable tree for planting in the valleys of the mountainons districts of Great Britain, as it yields large and most valuable timber.

The Dwarf Birch (Betula nana).-This dwarf 
ind be se for esnut, ording $r$ it is mes a more being of its e. eping rrowbogs, luded Asia, birch nsylnet hern luces the an time p to it is the elds

variety is a low shrub, a native of North Britain and some other European countries, and makes a very pleasing variety when associated with other trees in positions suitable for its growth.

The Walnut (Juglans).-The walnut, though generally regarded as a fruit-tree, and not a timber tree, yet furnishes very superior timber; in the east of France, the south of Germany, and Switzerland being very abundant; and in the plains of the Bergstrasse, which run parallel to the Rhine, between the Neckar and Mayn, there is hardly any other timber tree to be found.

It belongs to the natural family Terebintacees, and to the Monocia polyandria of the Linnæan system, the flowers of the genus being unisexual, and both sexes are produced by one plant, there being various species, all of large growth and yielding valuable timber. There are also several varieties of the cominon walnut, as the large, the thin-shelled, the thick-shelled, the late ripe, the double, and the French walnut.

The Royal or Common Walnut (J. regia). - A line of walnut-trees make a capital screen for an orchard of fruit-trees, but the course of treatment should be different according to the intended application, or purpose for which the tree is designed. If meant to stand for timber they should be sown in the place where they are intended to remain, in order that the tap root may be preserved intact, which, if once broken, the tree ceases its npward growth, and 
inclines to throw out side branches. But if meant for producing fruit, the transplantation destroys the tap root, and renders the tree more fruitful; those trees which spread their roots nearest the surface having the best-flavoured fruit, and in the largest quantity; while strong tap roots encourage the growtl of timber. Trees that have never been removed do not ripen their fruit so early in the season as those which have undergone removal, the vigorous tap root, when it has not received the check of transplantation, striking deeply into the ground, its propensity to do this being greater even than that of the oak, which causes it to be an exceedingly appropriate tree when the top soil happens to be thin and poor, but the subsoil of good quality. When its course has not been checked by removal, it will usually reach a height of twenty feet in twelve years, at which time it generally begins to yield fruit, and its progress is slower. Striking its roots deeply into the ground, it makes a capital hedgerow plant. as it does not obstruct the cultivation of the neighbouring land, and on this account is well worthy of more attention than it receives at the hands of farmers and planters generally, of which cultivators of the soil in other countries of Europe have taken advantage, it being perhaps the most common hedgerow tree throughout the Continent.

Trees of a great age are found in a late climate to ripen their fruit better than young trees in the same situation. Large quantities of walnuts are imported 
meant

ys the those urface argest e the been a the l, the the the even ceedns to ality. al, it velve fruit, eeply lant. eighy of $s$ of ators aken dge-

te to ame rted

into England from France and Spain every year. 'The tree is of great duration in this countre, anc? when grown lyy itself, and not crowded up by other trees, in $n^{1}$ am presents a very picturesque form, its $r$, whuons being somewhat similar to those of the oak. The light-coloured hue of its fol: re oflers a rich contrast to those of other trees, the leaves, when pressed with the fingers, emitting an agreeable aromatic perfune, its flowers beginning to open about the middle of April, and are in full bloom by the middle of May, before which the leaves are fully oul The latter are dropped early in autumn.

The walnut is thought so have been introduced into England from France, and used to be called the Gaul-nut previous to the year 1562 , but is supposed to be a native of Persia, and the south side of Mount Caucasus. It is the juglans, or nut of love of the Normans, and is probably the Persian nut mentioned by Theophrastus, being found growing wild in the northern parts of Persia.

In many parts of the Continent the wood is extensively used for domestic articles of furniture, for which it is extremely appropriate, being strong and tough in proportion to its weight, of sufficient size, and very durable, and capable of taking a fine polish. The winter of 1709 was so fate 1 to the walnut-trees throughout Europe, and occasioned so great a scarcity of its timber, that, in 1720, an act was passed in France to prevent its exportation, and its extensive 


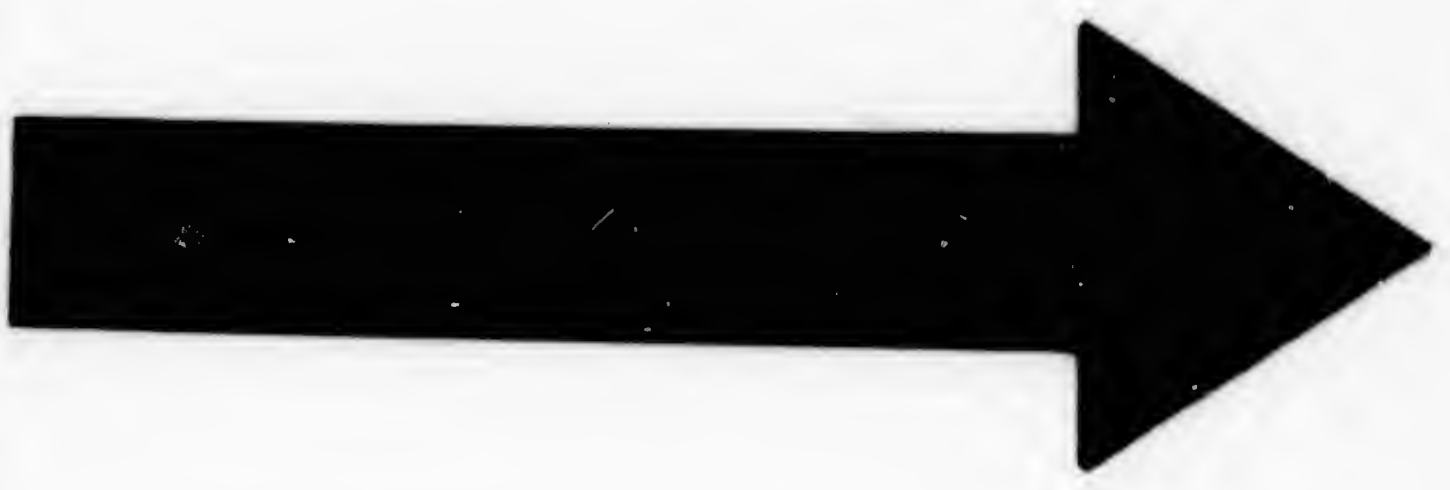




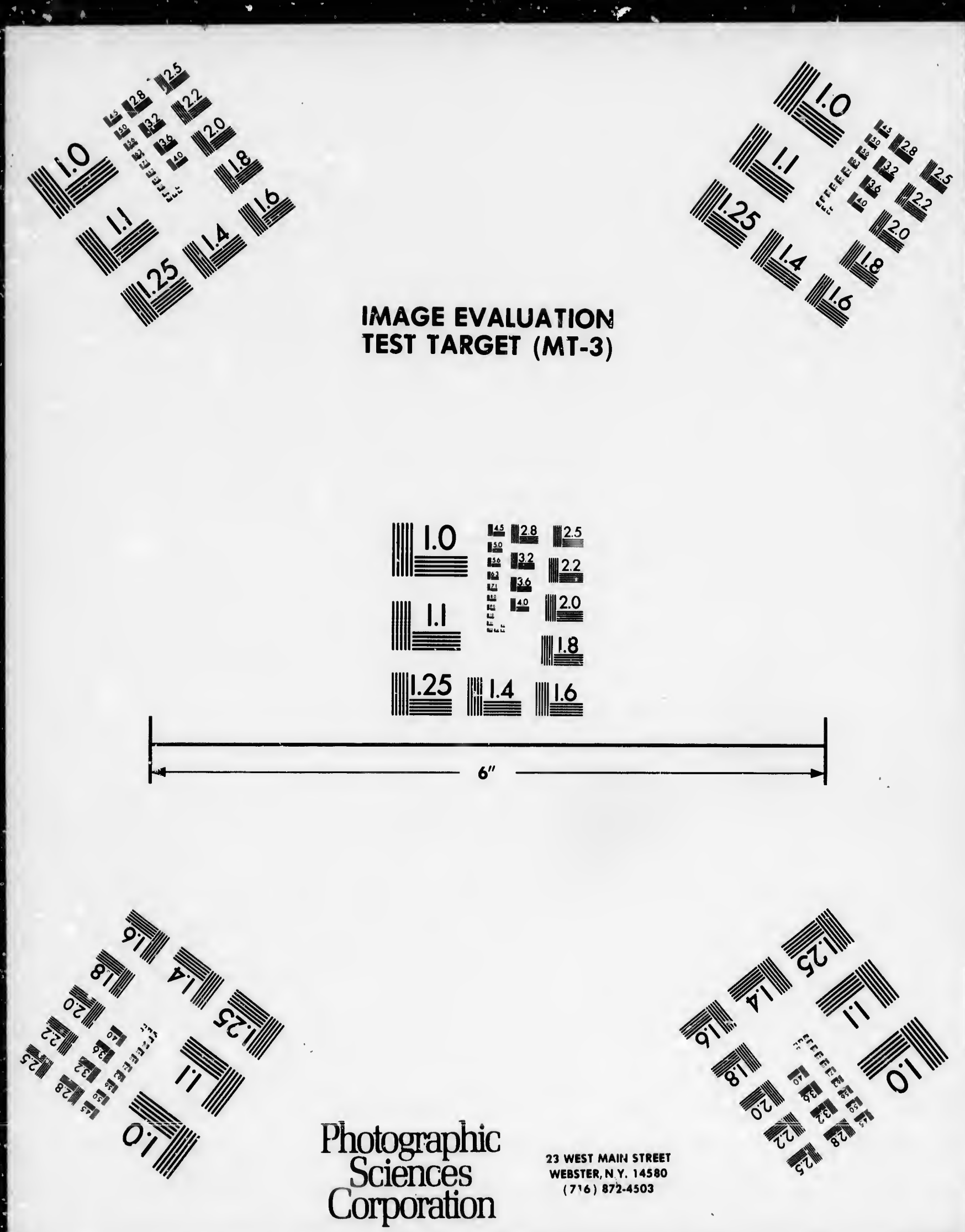



propagation was encouraged by the French Govelnment.

Alshough a good many walnut trees are scattered over the face of this country, there is no great amount of attention paid to the planting of the tree, which is one of a most useful description, a good many at one time having been felled for the manifacture of stocks of fire-arms, as before referred to.

Cultivation.-The walnut is propagated usually from the nuts or seed, or according to the method followed by Knight of budding, and when special varieties are sought to be reproduced, it is a good plan to graft, or in-arch on a stem of the common tree. The nuts part from their husks on becoming ripe, and falling from the tree, and may be sown in winter, or early in spring, as they vegetate during the first season, after being sown in drills a few inches apart, and covered with soil two inches deep. As the late frosts are very apt to injure the crop, when the plauts appear above the surface, the drills should be protected by branches of evergreens, or other light cover. On account of their liability to be injured by any degree of frost, it is best to raise the young plants on a dry, early soil; a poor, sandy seed-bed being preferable to a rich one, as they will not mature their shoots sufficiently in the latter to endure frost; for though the richest land wiil produce the larger plants, unless the winter is very mild, or the climate very superior, the first winter will deprive them of their tops. 
When the intention is to raise trees chiefly for the fruit they yield, as the seedling forms strong tap roots, they require to be transplanted at one year, or at most when two years of age; at the time they are lifted, the extremivies of the tap roots being pruned off in order to encourage the bushiness of fibre which is essential for the growth of young trees that have been transplanted. When plants of large size are required, the transplantation should be continued every second, or third year, increasing the space for the plants to stand in, according to their size. In a good climate, in a deep, dry soil, the walnut grows very rapidly, and is a very satisfactory tree to cultivate.

The timber when young is white and soft, but gets dark and solid as it advances in age, eventually becoming shaded, and veined; the most ornamental portions being generally found in the vicinity of the root, its hue consisting of a mixture of light brown and black. It neither cracks nor warps, and is considered the most ornamental timber we have in Europe for the purposes of the cabinet-maker. The roots when boiled yield a useful dark brown dye, which becomes fixed in wood, hair, or wool without the aid of alnm, being a very permanent dye that cannot easily be obliterated from the skin and nails of the living body without a good deal of labour, as may be seen by the hands of those engaged separating the husks from the nuts in autumn, which are dyed a dingy, greenish brown. The fruit yields a valuable 


\section{4}

ENGLISH TREES AND TREE-PLANTING.

oil, which in the Sonth of Europe is made use of in the kitchen, for medicine, and burning in lamps ; and in Spain it is customary to sprinkle the gratings of old and hard walnuts, that have been peeled, upon various dishes, as tarts, \&c.

The Black Virginian Walnui (Juglans nigra).This variety was introduced into Britain about tho middle of the seventeenth century, its leaves being nearly twice as long as those of the common walnut, beingr composed of six or eight pairs of opposite leaflets, with a single leaf forming the terminal leaflet, and grows to a large size in North America. 'The leaves when bruised emit a strong aromatic flavour, as well as the outer covering of the nuts, which are rounder, and roigher than the common walnut, The shell of this variety is very laard and thick, the kernel small, but very sweet. It is readily raised from seed that is commonly imported, the tree being of robnst growth, exceeding that of the com$1110 u$ species; growirg in England with the same freedom of growth which characterises it in its native country, where it attains a great size, being sometimes found 100 feet lighl, but the fruit is inferior to that produced by the ordinary kind of tree most common in England, and is also later in ripening. It is, therefore, only suitable for being grown as a timber tree, and occupying an isolated position, on a lawn, in a good soil, it becomes a large spreading tree of great beauty, and very valuable for decorative purposes, while its timber is of a lark colour, susceptible of a very high 
use of in aps ; and atings of ed, upon iggra).bout the es being walnut, opposite terminal Imerica. tromatic he nuts, common ard and readily the tree he comme freenative metimes to that ommon , thereer tree, a good beauty, lile its ry high polish, and is much esteemed for cabinet work, and general articles of furniture.

Altogether, the walnut-tree is a good deal too much overlooked in England, especially upon those thin soils which, having a good sub-soil beneath them, are capable of producing some capital walnut timber.

The Locust-tree (Robina Pseudo-Acacia). - The False Acacia, or Common Robina, is a useful and ornamental tree, belonging to Diadelphia decandria, in the Linnæan system. It is a native of North America, growing rapidly in rich, dry, and wellsheltered soils, where it attains a considerable size.

A great impulse was given to its cultivation in England, as before mentioned, by William Cobbett, who raised a great number of plants from seed that he imported, and which he sold under the name of Locust Tree, between the years 1820 and 1825 ; there having been, perhaps, no other tree of foreign origin that has been so enthusiastically recommended to the notice of planters.

It is not nearly so useful a tree, however, as many that are indigenous to this country, becoming feeble as coppice when frequently lopped over, not thinning as underwood, nor adapted for exposed situations, being soon hurt by the wind on account of its branches being brittle, and easily broken. Like many other trees, too, which spread their roots near the surface of the glound, before the bole attains a great age it is apt to become hollow in the 
centre. As posts while it is young, it is, however, remarkably durable, and in France is made use of to a large extent in the vineyards for supporting the vines.

The leaves come out late in the spring, and fall off early in autumn, like those of the ash, its finely shaped delicate leaves, and white pendulous, sweetsmelling flowers, recommending it as an ornamental slirub, rather than causing it to be valued for the sake of its timber, which, although of a very incorruptible nature when young, does not produce wood of sufficient size to be commonly useful, though for minor purposes it has a high reputation for strength and durability; in America being used extensively for tree-nails in shipbuilding, and for articles of turnery, being often substituted for boxwood.

Like many other trees of small size, it throws out shoots of great vigour during the first few years of its growth, but in our climate it requires the earliest, and best-sheltered situations to perfect them, often half of the extremities of the branches of young trees being cut off by frost, which will reduce a dundant growth down to the level of a very ordinity average. Notwithstanding this result, which causes trees to prove branchy, it lias a. natural tendency to grow erect.

It is after the age of ten, or twelve years, that it is seen at its best, when its white or yellowish racemes are very beautiful and fragrant, though it seldom blooms abundantly for a few years in succession, and 
lowever, ise of to ting the

$d$ fall off

is finely , sweetlamental the sake ruptible of suff$r$ Ininor gth and ely for urnery,

tlirows w years res the $t$ them, young $c$ a rdinatiy causes ency to

hat it is acemes seldom n, and

being late in coming into leaf, unless in a very forward season, it wears a bare look, when many other trees are clothed ir a bright livery of green.

The seeds become ripe by the end of October, but it is best to make use of those that are imported from America, when they should be first soaked in water, and sown early in spring. A light, well-drained soil, where the seed-bed gets all the advantage it can possibly obtain from sunshine, is the most appropriate, a very rich soil being only desirable where the climate is of the best description, and the seeds should be sown about two inches apart, and covered with half an inch depth of soil. The plants will make their appearance early in the ccurse of the summer, rising during the first season to eighteen inches and two feet in height, and seldom ripen their tops if they exceed this size. The young plants should be removed into nursery lines when one year old, the lines being two feet from each other, and the plants ten inches, or a foot asunder. They should be allowed to stand in these nursery lines for a year or two, when they will commonly get from five, to eight feet high, and are th $\cap$ suitable for being established in their final destinations. Sometimes, when the seed-bed produces the plants thickly, they are occasionally thinned out, and the remainder left undisturbed, standing at a distance of six or eight inches apart, and left thus in the seedbed till they are two or three years old, when they will be often found to measure five, to six feet high, and be fit for permanently planting out. 
The trunks of the trees do not generally exceed a foot in diameter, but there are a few larger specimens dotted about the country; one at Claremont stands seventy feet high, and has a trunk four feet in diameter, while another at Beaufort Castle, in North Britain, is about forty feet high, with a trunk that measures about two feet in diameter, at a distance of three feet from the surface; even in its native districts not generally exceeding one foot in diameter. In some parts of France, where the climate is more suitable for its growth than in England, it is cultivated in coppice, and in the form of pollards, that are cut every four years for vine props, in the same way that willow pollards are treated in this country, and the leaves and young shoots are there occasionally used for feeding cattle.

The Locust-tree of Scripture.-The Locust-tree of Scripture is generally thought to be the Carob-tree, which bears a fruit called the Carob-bean, which is grown extensively in the South of Europe, more especially in some provinces of Spain, where the seeds are eaten, and called 'St. John's bread.' Professor Martin says that, ignorance of Eastern manners, and of natural history, have caused some persons to imagine that the locusts upon which John the Baptist fed were the tender shoots of plants, and that the wild honey was the pulp of the pod of the carob, whence it obtained the name of St. John's bread, and that there is better reason to suppose that the shells of the carob-pod might be the husks which the prodigal 
exceed a ecimens t stands diameBritain, neasures of three icts not In some suitable ated in are cut ay that and the ly used tree of b-tree, hich is , more e seeds ofessor $\mathrm{rs}$, and $o$ imatist fed wild hence that of the odigal son, in the tender, and touching parable of our Lord, desired to partake of in common with the swine.

It ought also to be mentioned that, the locust-tree is sometimes raised from cuttings of the roots. 


\section{CHAPTER XII.}

FAST-GROWING AND SOFT-WOODED TREES, AFFECTING MOIST SITUATIONS.

\footnotetext{
THE POPLAR-THE GRAY POPLAR-PROPAGATION-THE WHITE POPLAR THE ASPEY-COLTIVATION - THE LOMBARDY POPLAR- BLACK ITALIA POPLAR-ONTARIO POPLAR-TIE WILLOW-THE WHITE OR HONTING DON WILLOW-THE GOAT-WILLOW-THE WHPING-WILLOW-TONTING-PROPAGATION-THE HORgECHESNUT-COLTE propagation.
}

WE now come to a different order of trees, which it will be most convenient to embrace under the heading of fast-growing, and soft-wooded trees, which succeed best in moist situations, the principal varieties of this order being the willow, poplar, alder, horsechesnut, and lime. Although these will often maintain a fair show of vigour upon dry, and even sandy uplands during their early youth, if the soil has been well trenched previous to their being planted, yet, after a time, they will give unmistakable signs that they are not in their proper place, and wear quite a different aspect to trees of the same order that are planted near water.

Many of these, as the weeping willow, are extremely graceful objects, though the alder cannot exactly be called a good-looking tree; while many 
persons have a great objection to the poplar, which often, indeed, in some varieties, has an ugly, bare trunk in old age, but are all extremely pretty during their youth, and on this account are capital trees for producing an immediate effect in situations that are naturally bare of trees, where these can always be planted with advantage, even if they are cut down after having performed the office for which they were designed.

The goat-willow (Saliv caprea) is a fast-growing tree, which throws out a number of beautiful yellow catkins during the latter end of March, when the bloom of trees and flowers is by no means plentiful. It is not frequently the case that, regular plantations are made of this order of trees, save in the case of willows or osiers for basket-making, which for the most part become valuable, and are grown on ground that could not be made available for any other crop. Upon strips of land by the side of open ditches, by streams, and around pools, the banks of canals and canalised rivers, and scattered over extensive meadows, the willow tribe can be made highly ornamental and useful, as vell as being made serviceable for fixing the banks of rivers, and for preventing the washing away of the soil by the water, which often makes great inroads upon the embankments of streams that are unprotected, and subject to the visits of periodical floods.

The poplar, though not a favourite with many, particularly those whose eyes have been accustomed.

re ex-

cannot

many 
to look upon the monotonous rows of poplars that are seen in France, and other parts of the Continent, which they have learned to dislike when abroad, and have sighed for the umbrageous shade of the trees peculiar to Britain, is yet a tall, graceful-growing tree, and forms a capital contrast when planted amongst round-headed trees, the aspen especially, with its fluttering leaves, giving an air of life and motion that will be found very agreeable when it occupies a space upon which trees have never grown before; and it is to this order that late planters are very much indebted, who sigh for that complete sylvan finish to some modern retreat, which the presence of trees can alone furnish.

The Poplar (Populus), natural family Amentacea ; Dicecia octandria of Linnæus.-The poplar is said to derive its name from the public places in ancient Rome being planted with rows of this tree, whence it came to be called arbor populi. The genus is composed of deciduous trees which produce unisezual flowers, those of the two sexes being placed on separate plants. There are many species which have come to us from all quarters of the globe; several of which are very diversified in foliage and form; nearly all being of remarkably quick growth, and on this account a very valuable order of trees for giving an immediate effect.

In favourable situations some of the poplars will make shoots sixteen feet long in a single season, and three inches in diameter; though this, of course, is a 
ars that

ntinent, ad, and le trees ng tree, mongst ith its motion upies a pefore ; e very sylvan nce of

acece;

said ncient nce it comexual $d$ on have ral of early this $g$ an

will and is a

very unusual growth. The small-leaved white poplar is found in most European countries, and some little doubt exists whether or no this, and the large-leaved one, the abele, is a native of Great Britain ; some little doubt existing on this head from the fact that, most of the plants of it in the seventeenth century were imported from Flanders. Thsre are about sixteen species of the family of populus, most of them being tall, straight trees, with branches rising up perpendicularly, instead of spreading out horizontaily, as is the case with the great majority of trees.

The Gray Poplar (P. candescens).-A native of Britain, the gray poplar is a fast-growing, somewhat spreading tree, which flowers in April, making a conspicuous show of large catkins that measure two or three inches long. It grows most rapidly in moist soils, and produces strong lateral shoots that are nearly equal in strength to those of the top shoot, and on this account is often made use of, and associated with other trees, with a view of its removal after more valuable kinds have become established, and is thus a very useful agent in the hands of the planter who requires sylvan decoration at once, in a naked situation, the ordinary growth of this species being thirty, to forty feet in ten years. When established by itself in a rich, moist soil, it rises with a clean bole, and attains a considerable size, producing a large amount of timber in a very short time. The timber, however, is soft and light, and is seldom grown profitably after a period of forty years, or, at the 


\section{ENGLISH TREES AND TREE-PLANTING.}

outside, fifty years; after which its trunk commonly begins to rot in the centre, when its value as timber is destroyed. The wood is chiefly used for packingcases, though 'on account of its being less liable to catch fire than pinewood, or fir, it is sometimes used as flooring near to fireplaces; and as it does not warp, is found useful for making doors, boardings for carts, and barrows; timber for carvers, and similar purposes where a soft wood that is easily worked is wanted.

Propagation.-Although it can be raised from seed, whic'. generally gets ripe in June, it is most readily propagated by layers in the way described for the elm; when cut down at an early age forming a stool quickly. After being one year transplanted, the plants are often five, or six feet in height, and are fit for being planted out. At an advanced period it springs freely from the roots, and on this account is often considered objectionable for some situations, as it fills the adjoining land with suckers.

The White Poplar ( $P$. alba).-The White Poplar bears a close resemblarre to the preceding, and although not so vigorous a tree is a finer one. (A variety with larger leaves is called the Abele poplar.) The unper surface of the leaves is of a darker shade of green than $P$. canescens, while the under portion is downy, and of a clearer, brighter, white hue, which gives it a much more conspicuous appearance when agitated by the wind; the most beautiful variety being known as the white Egyptian poplar, which 
mamonly timber ackingiable to nes used oes not ings for similar rked is

from $s$ most bed for ming a lanted, and are eriod it ount is ons, as

Poplar , and e. (A oplar.) shade tion is which when ariety which excels in the possession of leaves of the darkest hue of green above, and the brightest white beneath, of any of the species ; it is, however, not such a strong, vigorous tree as the common variety. The white poplar has a straight trunk, covered with a smooth, whitish bark, and it has suffered of late jears from an atmospheric disease in many districts, from which the gray poplar has been exempt, even when grown in its company, bligh's generally being contrgious. It is a good tree for producing an ornamental effect on the margins of lakes and ponds, on islands, and in similar situations, growing vigorously near water ; and also forms good plantations in moist situations.

The Aspen, or Trembling-leaved Poplar (P.tremulo). -This is a beautifui tree of stately appearance, which derives its name from its leaves, which are roundish and broadly toothed, smooth on both sides, with long, slender, compressed leaf-stalks, which move with the least breath of wind.

It is a native of Britain, and is common in mountainous situations in Europe and Asia, being tall in proportion to its girth, with a round head, extremely hardy, and of rapid growth, attaining a considerable altitude in almost any description of land, growing freely when young, in dry sandy soils, as well as in wet and strong land, which is better adapted for its subsequent career.

Upon soils of an average quality, the aspen will grow at the rate of three feet annually during the first ten years of its life, and when standing alone in 
a meadow, or upon a lawn, will assume a pendulous habit. It is a tree that is very serviceable in the hands of a landscape gardener for picturesque effect, for disposal on sloping hilisides, the margin of plantations, or in clumps or groups, as its foliage forms a contrast to that of other trees during the summer, being of a beautiful green, which after being touched by the first frosts of autumn, change into a more mellow hue, and ultimately turn into a bright yellow; while the quivering of the leaves is perceptibly heard, as well as seen, during comparatively calm weather.

The timber, like that of the other poplars, is but of poor quality, though appropriate for special uses, the trunk being of an ash colour in trees of developed growth.

Cultivation.-The seeds get ripe in summer, and may be sown at once, but the best method of propagation is by suckers, or layers, which is the most speedy way of obtaining trees; cuttings from the roots will strike freely, but not cuttings from the branches, like many other poplars, which take root readily when merely stuck in the ground. It is, therefore, the best plan to lop a stool over in the manner before described, one- or two-year-old transplanted layers being usually from five, to six feet high, wheri they are fit for planting out. The roots of the aspen spread over the surface of the ground, and when the vigour of the young tree subsides, and all itsstrength is not principally directed to the maturing of its trunk and branches, in many situlations it 
ndulous in the le effect, plantaforms a ummer, touched a more yellow; y heard, eather. , is but al uses, veloped

er, and propae most om the om the ke root It is, in the transix feet e roots rround, es, and maturtions it

has an objectionable tendency to produce suckers from the roots, which causes a kind of jungle to form around the tree in neglected grounds, though it offers an opportunity to those desirous of obtaining a stock of young plants, and may be kept down by proper care and attention, by those who do not require them.

The Balsam Poplar (P. balsamifera).-The Balsam Poplar is a native of Siberia and North America, and derives its name from the fact that the buds of the tree, from autumn to the following leafing season, are covered with a glutinous, yellow balsam, which often forms into drops, and is collected for medicinal use; the balsam being exported from Canada in shells.

In North America it rises to a height of eighty feet, but in Britain it is a much lower tree, growing vigorously only for a few years when quite young, being only fit for ornamental purposes, and not to be grown as a timber-tree. In the spring, its opening leaves are of a pale yellow colour, which emit a rich balsamic fragrance, which is diffused in the surrounding air, eventually beconing of a fine, dark green hue, the young wood being of a rich chesnut colour.

The balsam which is imported into this country from Canada is of a smooth, even texture, yellow in colour, with a fragrant smell, its flavour being somewhat similar to that of Tulu balsam. It is said that grouse and other game birds, which are in the habit of feeding upon the buds of the balsam-tree during winter, acquire a recherché taste when served at table, which is much relished by epicures. 
The Lombarly Poplar, or Fastigiate (P. fastigiata). -This well-known tree is distinguished by its upright growth, its lateral branches growing close to the stem, rising upwards in a tapering form, and is a native of Italy, being frequently met with, more especially on the banks of the Po in Lombardy.

It was introduced into this country about the middle of the eighteenth century, and soon became a common tree, being easily increased to any extent by cuttings. It is an excellent variety for standing in towns and cities, as it bears the effect of smoke better than alınost any other tree, and will flourish in a narrow space. When young it will grow rapidly in almost any soil, but in order to be developed to its fullest size it requires a rich, deep soil, in a situation where its roots can have access to water. $A$ tree is recorded to have grown on the banks of a canal in the neighbourhood of Brussels that in fifteen years grew to the height of eighty feet, its trunk being from seven to eight feet in circumference. At an advanced age the bole becomes very furrowed, and is often considered unsightly, but is not, apt to produce undergrowths. There are other trees which will yield a greater amount of timber, but none will rise so high in the space of twenty years as the Loinbardy poplar.

Fences are commonly formed of the fastigiate on the Continent, the method of doing this being to insert two year old plants in the ground about six inches apart in straight lines, when they will be six or seven feet high. These are connected by a hori- 



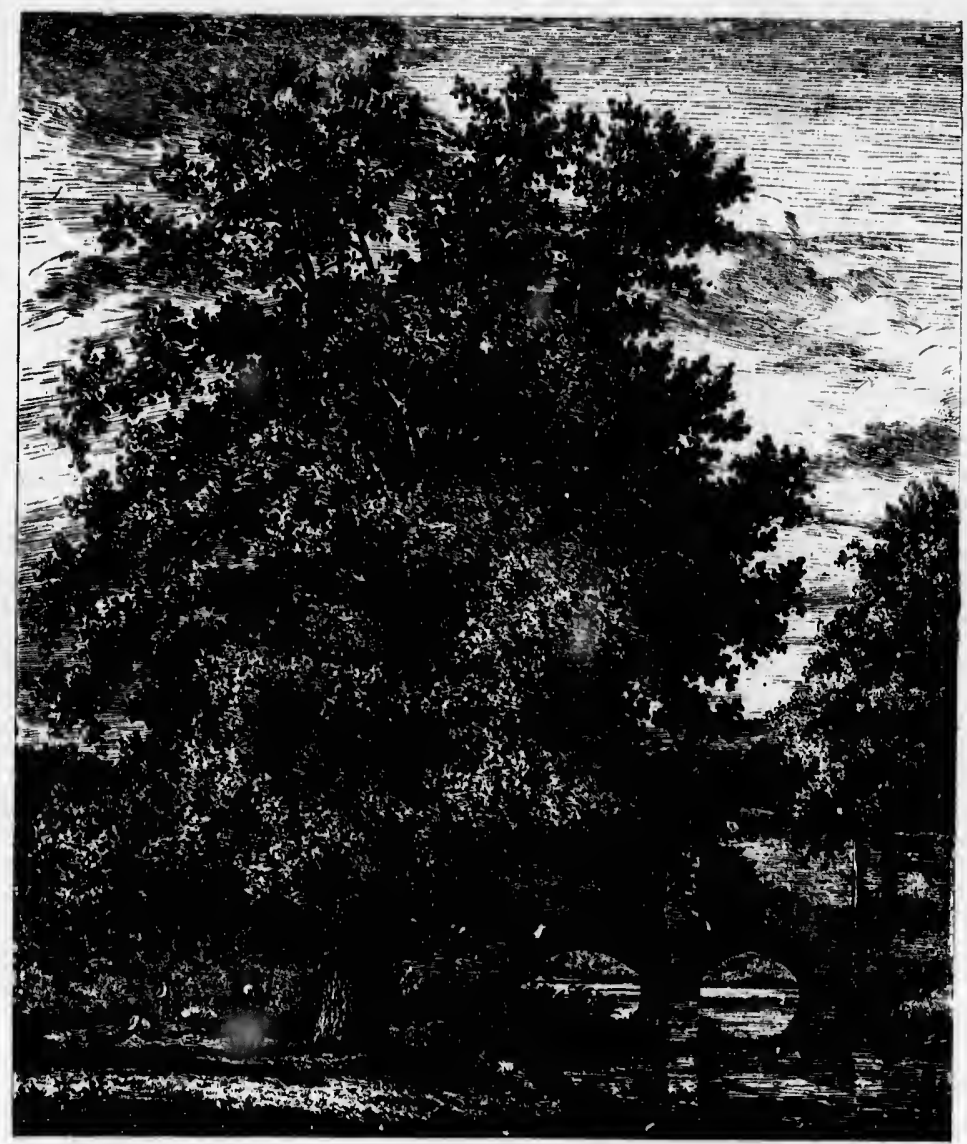

Black Bhiat at Bury fodmuends 
zontal rod, placed at the height of three feet from the ground, and thus a compact fence is made at once, in the progress of a single season. They are lopped in the course of a few years, and sometimes the trees are thinned out, which enables the remainder to acquire considerable dimensions, when a fence is formed of tree-trunks of a very solid description.

In France this variety attains a great height, some trees on the banks of the Seine at Rouen standing 150 feet high, and in this country trees are met with which range from 100 feet to 125 feet in height. As the cuttings will grow when inserted in the ground as readily as the willow, this species is propagated with the greatest ease.

Black Italian Poplar (P. monilifera).-This variety is sometimes called the necklace-bearing, as well as the Vanadian poplar, and is a tree of very rapid growth, being found growing in the district between Canada and Virginia, on the margins of lakes, where it generally attains a height of seventy or eighty feet, but is found reaching a higher altitude than this in Great Britain, on rich moist soil, becoming a large timber-tree in the space of a very few years. Its growth is more vigorous than that of the gray poplar, the side shoots taking a more horizontal range, being readily distinguished from the Lombardy poplar when a plant; by its young shoots being fluted towards the extremities, and of a darker colour; its leaves being also broader. It will grow well on poor soil, if its roots have access to water. 
When reared in plantations for the sake of its timber, the trees should stand moderately close, as a certain degree of confinement (without over-crowding) impedes the too luxurious growth of side branches, trees being known at the age of twentyfive years to reach a height of sixty feet, and contain forty-six cubical feet of timber. The wood makes good flooring, being very white, and also durable, if kept dry. The variety is easily propagated by cuttings.

There are several other species of poplars that are mostly of American origin, but are not very often cultivated, amongst which may be mentioned the Ontario poplar ( $P$. candicans), which a good deal resembles the balsam poplar, but has large heart-shaped leaves. This latter variety, however, cannot be grown profitably for timber, the branches becoming brittle as soon as the tree ceases to grow vigorously.

The Willow (Salix).-Natural family Amentacea ; Dicecia; Diandria of Linnæus. There have been enumerated about one hundred and forty different species and varieties of the willow, natives of widely different parts of the globe, and ranging in stature from the smallest kinds, known as osiers used in basket-making, of a height of only a few inches, to lofty trees which tower upwards fully eighty feet, there being no genus of plants, perhaps, which is so confused as the willow. This is said to have arisen from several causes, partly on account of many of the leading kinds having hybridised, and yielded a 
of its

, as a

rowd-

side

venty-

ontain

makes

tble, if

y cut-

at are

often

d the

al rehaped

grown

brittle

acea ;

been

ferent

videly

tature

sed in

es, to

feet, is so

arisen

ny of

ded a

great many intermediate varieties, and partly from the reason that, each species contain male and female plants, while the same species differ in appearance at certain times of the year, and the tree is apt to alter, and change its appearance from a variation of soil or climate.

About thirty species are natives of Britain, and these have been subdivided again into several more divisions and classifications, but there is no difficulty in naming and describing the most prominent kinds that are likely to be of service to the tree-planter, and best answer his purpose. We have understated the case, indeed, as to the great number of British and foreign willows that can be enumerated, for in quoting 150, that number of willows is figured and described in the Salictum Wobernense of the Duke of Bedford, which was published in 1829 , and since that time the entire number of species and allied varieties which have been enumerated in more recent publications amount to several hundreds, the numbers having been swelled up by the causes we have cursorily alluded to.

The willow is extensively used in the manufacture of charcoal, and is found superior to most other wood for producing that used in the manufacture of gunpowder; and although this application is but comparatively a very subsidiary one at the present time, the large consumption of charcoal in his day excited the fears of Evelyn, who, in his Sylva, states his apprehension that the progress of our iron manufacture 
would lead to the destruction of all our timber in the preparation of charcoal for furnaces, in 1788 there being eighty-six iron furnaces in England, of which twenty-six were heated by wood. At the period at which he wrote the contrivance of 'coking' coal was not known, and matters had so far altered in 1826 that there were then 305 iron furnaces in England which consumed coke in the manufacture of iron.

The White, or Huntingdon Willow (S. alba).-_This variety is more frequently planted as a timber-tree than any other willow, in favourable soils and situations growing from fifty to eighty feet in height, and forming a trunk from two to three feet in diameter. Excepting the gray poplar, there is no tree that produces so large an aniount of timber during the first twenty-five years of its growth. It makes a good pollard tree, and stands repeated loppings of its branches, its year-old shoots being remarkably strong and tough.

Russell's, or the Bediord Willow (S. Russelliana).This is another excellent variety for the production of timber, deriving its name from the Duke of Bedford, who first directed attention to it and brought it into notice. It will attain a height of upwaids of fifty feet, with a trunk from eight to nine feet in circumference, Johnson's willow at Lichfield being of this species; which was recorded some years back to have measured forty-nine feet in height, with a girth of trunk of twelve feet. 
The Goat Willow (S. caprea).-This is one of the most useful varieties amongst the broadest-leaved of the willow tribe, and deserves to be made use of to a greater extent than now obtains, though it is a common enough tree, and springs spontaneously in waste ground, especially in cold and marshy situations. The rapid progress it makes during its early youth is also a permanent one, its vigorous shoots being generally ripened to their extreme ends, and are not cut off by frosts, as is frequently the case with many quickgrowing trees, a two-year-old seedling plant commonly throwing out several shoots three or four feet in length; and invariably perfecting them under the most inhospitable circumstances. These shoots have a rich, glossy bark, which agreeably contrasts in spring time with the buds, that are white and prominent, which, again, relieved by the profusion of yellow catkins displayed by the male plant, give to it a bright and handsome appearance, which is often very striking when seen growing on sone swampy waste piece of land that otherwise would present a very dreary appearance.

The goat-willow, or sallow, is a capital tree for coppice, which may be cut down every three or four years, no other tree yielding so great an amount of loppings in an equally short period ; the produce being appliçable for poles, sheep-fences, rods for crabs, hoops, \&c., a vigorous stock on a congenial soil sometimes producing in one season a number of straight, clean shoots that vary from eight to twelve 


\section{4}

ENGIISH TREES AND TREE. PLANTING.

feet long, some of them being an inch in diameter at two or three feet from the ground.

In maritime situations it can be made the means of giving valuable shelter, as it withstands the effects of the sea breezes and spray better than most other plants. As a tree it will attain the leeight of forty or fifty feet, with a trunk from one and a half to two feet in diameter; and the timber is considered to be of better quality than that of any other of the willows.

Willow timber is useful for a large variety of agricultural purposes, and there are waste pieces of land upon many farms that are turned to no profitable account, that might be planted with willows to great advantage, and their produce be found to come in very acceptably. Being white, soft, and light, it is well adapted for rake and scythe handles; and the young wood makes capital hurdles, being lighter than much that is commonly used, such as hazel, and on this account is much handier, and allows of their being more readily moved from place to place, and less likely to become damaged when flung down upon the ground, which is commonly done, when they are injured by their own weight.

Willows can also be made the means of furnishing permanent embankments in those situations whe rivers and streams are apt to encroach upon the land. The branches are cut between October and April, and are formed into a kind of frame, which is made to extend from the channel of the water to the top of 
means

effects

other

rty or

o two to be of the

ety of ces of profitws to come $t$, it is d the ighter l, and their , and upon are

shing hisute

land. , and de to p of

the flow-bank, in the form of a gentle slope; the larger timbers being interwoven with the smaller spray, and the whole being covered with a few inches of the soil of the banks, gravel, or sand. After a short time the branches will throw out numerous fibres, and thus create a surface vegetation, which will resist the prejudicial action of the waters, by the consolidation of materials of a shifting character, and the willows being lopped yearly, a permanent embankment becomes established; and it is by resorting to such contrivances as these that the value of land becomes considerably augmented in certain situations; and trees of one kind or another can be made the agents for effecting considerable improvements.

A deep, rich soil in the neighbourhood of water develops tree-willows the best; but being extremely tenacious of life when young, they will grow and thrive in a greater or lesser degree, in soils of almost any quality, the willow being found occasionally in the driest land at high altitudes.

Of the dwarf willows, or osiers, we shall speak again under the heading of 'Osier beds,' of which there is a very great variety, and which could often be very profitably grown by the agriculturist whose land abuts upon tidal rivers, that are occasionally subject to overflow ; and we will conclude our notice of this variety in this section of our work by a short notice of the most ornamental of the species-the weeping willow.

The Weeping Willow is said to be a native of the 


\section{6 lWOLISI TREES AND TREL-PLAN'TING.}

Levant, the first that was planted in England being ascribed to Alexander Pope, at his villa in 'Twickenham. 'The account given of this circumstance is, that the poet received a present of a basketful of figs fiom Iaady Mary Wortley Montagu, from Turkey, and observing a twig in the hamper in which they were packed putting out a shoot, he planted it in his garden, and it soon became a fine tree, from which tive stock of weeping willows in England have originated, which now adorn the margins of many a lake and pond throughout the country ; and it is fortmate for the lovers of this tree that this little episode oecurred before his change of feelings towards Lady Mary, an account of which is very amusingly given by 'Thackeray, who says: "He wrote flames and raptures, and elaborate verse and prose, for Lady Mary Wortley Montagu; but that passion probably came to a clinax in an impertinenee, and was extinguished by a box on the ear, or some such rebufl; and he began on a sudden to hate her with a fervour much more genume than that of his love had been. It was a feeble, puny grimace of love, and paltering with passion. After Mr. Pope had sent ofl one of his fine compositions to Lady Mary, he made a second draft from the rough copy, and favoured some other friend with it. He was so charmed with the letter of Gay's that I have just quoted that he had copied that and amended it, and sent it to Lady Mary as his own. A gentleman who writes letters it deux fins, and after having poured out his heart to the beloved serves up 
being Likenthat fiom d obwere gialtive ated, and ce for arred Aary, n by rapMary came ished benuch t was with s fine draft inend Galy's t and $\Lambda$ after es up

the same dish rechauffe' to a friend, is noi very much in earnest about his loves, however much he may be in his piques and vanities when his impertinence gets its due.'

The Alder (Alnus glutinosa).-The alder belongs to the same natural family as the birch, but is not nearly so good-looking, being by no means an ornamental tree, its mamner of growth being somewhat uninteresting and gloomy, being altogether a plain kind of tree.

It is a native of almost every country of Europe, and thrives best in marshy situations, and may be regarded as the most aquatic tree indigenous to Britain. Although in some situations it may be seen growing more in the form of a large shrub than a tree, yet in others, when planted in a congenial soil in damp situations, or on the edge of rivers, it sometimes attains to the height of sixty feet. As it reaches, its prime when fifty or sixty years old, where timber is the object it should then be felled. When of considerable size, the imber of one of the varieties, of which there are several, is of a reddish colour, and often very finely veined, being sometimes locally called 'Scotch mahogany,' bearing some resemblance to mahogany when polished, though of a duller colour.

The bark of the alder contains a good deal of tannin, and if cut in spring the shoots dye a cinnamon colour, and the eatkins of the flowers a green, and for this purpose is resorted to by dyers in county 
districts, and especially in the highlands of Scotland. The largest trees that have been recorded is one that stood near the village of Haverland, in Norfolk, which measured, at the time its dimensions were taken, sixtyfive feet in height, and the bole, at a foot from the ground, twelve feet in circumference; and another, which stood in the Bishop of Durham's park at Bishop Auckland, was somewhat smaller.

The twigs of the alder are brittle, as well as the stem when green, but its uses are very varied and considerable. The shade does not injure the grass, and coppices of it are very useful for wintering outdoor stock on mountain grazings; and it supplies a large quantity of faggot-wood, and wood for making hurdles. The timber is used by last-mahers, cabinetmakers, turners, and others who require a soft wood to work upon. In fenny districts, where other varieties of trees refuse to grow, the alder makes a capital ledge plant; and also is found to be a free grower for several years on many soils of an opposite character, if the land has been well trenched. It is, therefore, a good tree in the hands of the planter who is desirous of making an immediare show round newly erected buildings, which lack the finish and adornment that trees are able to afford; while it is a good nurse for other sorts of a more valuable description that are sought to be established by the sea-side, where, without such shelter, they would refuse to grow.

As a reclaimer, however, of low-lying meadow 
land which is subject to being partially or continually flooded, the alder can be made to play a very important part. This is effected by ridging up the soil where the trees are intended to stand in summer time, and planting the young trees upon it in the spring. After they have stcod for a few years, the continual droppings of the leaves, and by the growth and fixing of the roots in the soil, the land becomes eventually dry and firm, and the intruding water kept off the adjoining land. By the edges of rivers, or in damp, low-lying situations, in planting the alder the soil requires no other preparation beyond ligging; the best times for planting being November and March, when the plants should be inserted in holes nine inches deep, made with a common garden spade, the distance at which the plants should stand from each other being four feet, and afterwards cut out as they increase in size, and thinned according to the vigour of the plantation.

Propagation.-The alder is best propagated by sowing the seeds, though it may be increased by suckers, or layers, the seeds being contained in small cones, which are renerally fit for gathering in the last fortnight in October. These, when collected, should be spread on a dry floor to the depth of six inches, when there is no chance of their getting mouldy; as over a harness-room, where there is a fire often kept up, and where the warmth beneath can reach the cones spread above; and here they should be allowed to remain till the first fortnight in 
April (the cones being turned over frequently in the meantime), when they should be thrashed, sifted, and cleaned, and slightly moistened for twenty-four hours, milk and water being recommended for this purpose.

The best site for a seed-bed is that of a moist meadow, which, after being dug over evenly, and finely (but not raked), should be marked out in beds four feet wide, with an alley of a foot width between the beds. The seed should be sprinkled upon the beds almost as thickly as it can lie without touching, and should then be carefully trodden in by the feet, until the soil becomes flat and even, and the seeds become blinded, as it is technically called; for they require no other covering. In moist meadow land, which is the best adapted for the purpose, the young plants will be nine inches high by November, or perhaps even higher; and they should then be transplanted into lines a foot and a half apart, the plants standing in the rows about six inches from one another. After standing thus for a couple of years they will be fit for being planted out permanently.

At one time it was customary to propagate alders by planting truncheons, or good-sized stakes which were lopped from off a pollard tree, the same being also done with willows; but this plan has been abandoned in favour of the one by raising plants from seed, which is the more reliable method; and nurserymien now make the raising of young trees such a prominent part of their business that the young plants can be bought very cheaply, and if 
$y$ in the ted, and $r$ hours, purpose. a moist ly, and in beds between pon the uching, he feet, e seeds or they land, young ber, or e transplants m one years itly. alders which being been plants ; and trees at the and if

purchased from those who made this branch their special study, the young trees will be in a reliable condition for planting out, each having been treated according to its special requirements, which the preceding pages will to a great extent have explained.

In some parts of the country the bark of the alder is stripped off a year before it is felled, but this looks unsightly, and may as well be done immediately after it is cut down, which is done in winter time. As the wood is subject to the attack of insects, where there is an opportunity of doing so it has been recommended to immerse the finer portions, immediately after felling, in a pit of water dug in a peat bog; the water of the pit being impregnated with a bushel or more of lime. It is not everybody that has a peat bog at their command to resort to, but in some districts where these abound, the wood so prepared will be more valuable, it is affirmed, for the purposes of the cabinet-maker in the manufacture of tables, or other articles of furniture. Alder, from the ease with which it can be perforated when green, and from its freedom of liability to split, is well adapted for wooden pipes; and is useful as timber in moist situations, such as for foundation piles, \&c.

The Horse-chesnut (Asculus hippocastanum).Natural family Hippocastanece; heptandria, monogynia of Linnæus. This beautiful tree is a native of Asia, and was introduced into Europe about the middle of the sixteenth century, finding its way, it is said, in the first 
place, from parts of Northern Asia to Constantinople, and from thence to Vienna; afterwards to Paris, where the first tree is recorcled to have been planted in 1815. It is the largest ornamental tree we have, and may now be regarded as one of the best of English trees for the purposes of embellishment; producing a profusion of rich and beautiful blossoms, which individually form pyramids of large white flowers, delicately marked with red and yellow (the scarlet flowering, horse-chesnut being a smaller variety), growing very rapidly, its branches assuming the form of a paraboloid, closely clothed with opposite digitated leaves of a deep-green colour. It is a splendid tree for the formation of avenues, one of the finest we have in this country being that of Bushey Park at Hampton Court, when the trees are in full blossom attracting crowds of visitors from London to see them, the flower-stalks emerging above the leaves, and the blossoms being generally expanded by the end of May.

The horse-chesnut attains a large size when standing alone in a somewhat moist meadow ; and it is a beautiful object as a lawn tree, particularly suited to those somewhat damp soils in the neighbourhood of water where many other kinds of trees would not flourish. It is remarkable for the rapidity with which it forms the whole season's growth, which is usually completed in three or four weeks, which, as it gives the young wood an opportunity of being matured early in the season, causes the tree to be 
nople,

Paris, lanted have, est of ment ; soms, white (the naller iming h op$t$ is a of the ishey f full on to aves, the

when nd it uited hood not with $\mathrm{ch}$ is h, as eing $o$ be

well adapted for cold and somewhat unfavourable situations, though as a high degree of temperature is necessary to expand the blossoms, and cause it to put on its most attractive form, it is only in warm and sheltered situations that it produces blossoms abundantly.

Many comparisons have been instituted as being suitable to the horse-chesnut, some of a favourable nature, as the ' giant's nosegay,' the ' gigantic hyacinth,' wlile another of an unfavourable description fixes it as an einblem of ostentation, in reference to the gay appearance of its blossoms, and the profusion with which they are scattered on the grass, with the comparative usclessness of its timber, and the worthlessness of its fruit, which is put to no useful purpose in this country; but although even hogs refuse to eat them either boiled or raw, sheep and deer will eat them whole, while, it is said, poultry will do so when boiled; while the Turks are accredited with the practice of grinding the nuts, to mix them with the food of their horses, from which, according to some, is the derivation of the name. Starch is also said to lave been made from them upon the Continent, where they are grown in considerable numbers in soine places.

The timber is soft and spongy, and not durable, and is therefore but of little value; its chief recommendation being that, as its fibrous roots permit of its being removed with safety when of a larger size than most treses will allow of transplantation, particu- 
larly after being frequently transplanted, this excellent qualification causes it to be fit for producing an immediate effect in forming lines and avenues, which slower-growing trees would take several years to equal, and altogether being a most valuable tree for the purpose of decorating lawn or park scenery.

Cultivation.-The nuts become ripe about the end of October, and they can be sown any time during the winter, a rich deep soil being the best for them to grow in, although they will strike freely in almost any description of land. Large and sound nuts should be chosen, as the size and vigour of the young plants are a good deal regulated by the quality of the nuts. A bed twenty yards long, of the usual width of four feet, will take about a bushel of nuts. These should be laid on the seed bed, and beaten down with the back of a spade, to keep them in their places, and should have about an inch and a half depth of soil spread over them. Either at the ages of one or two years, the seedlings should be transplanted into nursery lines, about a couple of feet asunder, standing in the rows from eight inches to a foot apart, and afterwards again removed every two or three years, when plants of large size are wanted, in order to maintain that bushiness of root and fibrous nature which is essential to their future prosperity.

There are several of the smooth-fruited kinds with yellow blossoms, known as the genus pavia, the nut not being inclosed in a prickly shell, as is the 
his exoducing ivenues, al years ble tree enery. the end during or them almost nd nuts e young lality of 1e. usual of nuts. beaten in their a half the ages e transof feet hes to a very two wanted, oot and $r$ future

d kinds avia, the is is the

case with the ordinary horse-chesnut, while the scarlet flowering variety is a very liandsome dwarf tree, which produces its flowers at an earlier age than the common one, and is of very ornamental appearance, when blended witl otler trees, or standing by itself.

The Lime-tree, Linden or Teil-tree (Tilia Europaca). -Natural order Tiliacece ; polyandria, monogynia of Linneus. There are several species and varieties of this tree, which differ from one another cliefly in the size and shape of their respective leaves; the most useful of the range, and the one most commonly met with, being the common lime. It is a native of the north of Germany, Russia, and Sweden, and is found upon the Alps in Switzerland, in Spain, in Portugal, the north of Italy, and Greece, varying in its characteristics according to soil or climate; in the colder ones its fragrant blossoms not expanding to their full extent. It has been said by some writers to be indigenous to Britain, having been found growing wild in Kent and Essex; but as it does not shed its seeds and spring up in uncultivated ground after the usual manner of an indigenous tree, it most probably is not a native of this country, though mention is made of its growing here as early as the sixteenth century. Though not usually a very large-growing tree, there are enormons lime-trees to be seen in Switzerland and Germany, and one is mentioned by Sir Thomas Brown growing in Norfolk as being ninety feet high, with a trunk forty-eight feet in circum- 
ference at a foot and a half from the surface of the ground.

The lime bears the smoke of cities well, and on this account is a good deal used for forming a venues in the cities on the Continent, more especially in Germany, where it is planted in lines along the streets and public promenades. The blossoms expand in July, and are extremely fragrant in lot weather, the heat reflected by the pavement and buildings appearing to strengthen their agreeable odour. It likes a good climate, and a rich alluvial or loamy soil, being unsuitable either for bleak situations or dry poor soils, and in this country the seeds are only ripened in the best seasons, and upon trees that are the most favourably situated; and when this is the case, when several lime-trees of different kinds stand together, and blossom at the same time, the seeds become hybridised, and produce various sorts, even although they are gathered from one tree; and this causes it often to be a difficult matter to perpetuate the same tree from seed.

Occupying the best situations suited to its growth, it becomes a lofty tree with branches depending downwards, clisplaying a great mass of foliage, of fine for'm and texture, which causes it to present a very complete and handsome appearance, particularly refreshing to the eye and senses when met with in a crowded eity. The following passage respecting the lime-tree occurs in Landor's Conversations:- Old trees in their living state are the only things that 
money cannot command. Rivers leave their beds, run into cities, and traverse mountains for it ; obelisks and arches, palaces and temples, amphitheatres and pyramids, rise up like exhalations at its bidding; even the free spirit of man, the only thing great on earth, crouches and cowers in its presence : it passes away and vanishes before venerable trees. What a sweet odour is there! Whence comes it? Sweeter it appears to me, and stronger than the pine itself. I imagine, said he, from the linden. Yes, certainly. Oh, Don Pepino, cried I, the French, who abhor whatever is old, and whatever is great, have spared it. The Austrians, who sell their fortresses and their armies, nay, sometimes their daughters, have not sold it. Must it fall? Oh, who upon earth would ever cut down a linden?'

Though destitute of the picturesque character which distinguishes the oak and some other trees, it is well balanced, and of an easy habit, having a great number of lateral branches, which often adorn the cultivated grounds or park-like meadows in which it is planted; and on suitable land it often attains a great size in a short period.

Cultivation.-The seeds are ripe in autumn, and may be sown in winter or early in spring; but trees are seldom raised from seed, which it is often difficult to obtain fully ripe, and plants are usually procured from layers, a plant being lopped over at the surface of the ground, which is easily formed into a stoo!. In winter, or early spring, the young shoots are bent 
down into the ground to the deptl of three or four inches, with their extremities placed in an upright position, which forms the future tree. The plants become rooted, and can be removed by November, the laying down of the shoots being performed in the winter, or early spring previously. When these are taken away, the shoots, the produce of the preceding summer, should be bent down in the same way as the preceding ones. The shoots sometimes :equire to be manured, and on account of the silex which it contains, it is well to mix a little sharp sand with it, where the land upon which the shoot stands is deficient in that element. After the third year, a healthy shoot will furnish as many as sixty or seventy plants every year, which on their removel generally average about two feet high. They should then bo set out into nursery lines, about two and a half feet apart, the plants standing in the lines about fifteen inches from each other. When they have stood thus for two years in the nursery lines, they will generally be about six feet high, and fit for planting out in the situations they are intended to finally occupy. The young tree can, however, be made to attain a large: size than this, and be fitted for removal, if it is transplanted every second year, which causes the roots to become bushy, or fibrous; the allotted width in the lines being increased upon each removal, so as to permit of the shapely development of the plant as it increases in size. It stands pruning well, and although 
or four upright plants ember, 1 in the cese are eceding as the ce to be it conwith it, ands is year, a seventy nerally then be alf feet fifteen od thus nerally $t$ in the . The large: s transoots to in the as to at as it though

bare of foliage in the winter time, it grows twiggy, and forms a good screen where one is desired.

In rich, sheltered soil it will grow at the rate of two fect yearly in stature, for the first fifteen or twenty years; after which its progress becomes the most marked, where there is sufficient space for its lateral branches, while the diameter of the trunk is being increased, eighty feet being usually the maximum height it attains in Britain, though Strutt describes a lime-tree growing at Moor Park in Hertfordshire nearly 100 feet high ; while one is recorded at Cobham Hall in Kent, the seat of the Earl of Cobham, with a trunk nine feet in diameter, anu ninety-seven feet high.

The timber of the lime, although soft and weak, is yet uscful for many purposes, being delicately white, and of a uniform colour throughout, on this account being very appropriate for all light work that requires to be partially paintcd, and then varnished over. All the exquisite carvings which Grindley Gibbons executed for so many palaces and churches in England, at the time of Charles II., were executed in timber from the lime. Being close in the grain, it is a good timber to work upon, resembling the maple in its quality of not being subject to warp, which has caused it to be called the ' carver's tree,' carvers and gilders using it for most parts of their wooden ornaments, having a clear smooth surface, which blunts the tool less than any other timber in the hands of the carver; and on 
account of its not being likely to warp, it is used for cutting-boards, and for the keys of musical instruments.

As the trunk of the tree is tall, and free from knots, it admits of the bark being stripped off it in long lengths, which are macerated in water till the fibrous layers separate, which are then divided into narrow strips. This is called bast, and in northern Europe it is worked into mats, and plaited into ropes ; the mats which are imported from the Russian ports in the Baltic, in which flax and hemp are packed, being made from the bark of the lime-tree in this way, and which is familiar to gardeners from the use they make of them in covering up delicate plants in the winter, as also in detached pieces for tying them up. As well as mats, ropes, nets, and coarse cloth are made from the inner bark, and in Russia the outside bark is frequently used instead of tiles for covering houses. The honey, the produce of the bees which feed on the blossoms of the lime, is considered to be of the finest quality that can be procured. Loudan points out this fact, and its remarkable delicacy, which causes it to sell at three or four times the price of common honey, being exclusively used in the preparation for medicine and in the manufacture of liqueurs, and procurable only at the little town of Kowno, on the river Niemen, in Lithuania, where there are large forests chiefly composed of this tree, 
sed for instru-

from fff it in till the ed into orthern ropes ; a ports backed, in this the use ants in g them cloth sia the les for of the is cone proemarkor four usively in the nly at len, in com-
The leading varieties of the Tilia Europaca are the broad-leaved platyplylla; the small-leaved microphylla; the red-twigged rubra; the cut-leaved laciniata; the yellow-twigged aurea; and the whiteleaved alba.

The American Lime (T. Americana).-There are several varieties of the American lime, which very nearly resemble the European species, but are hardier, and the leaves vary in size according to the different varieties, being finely serrated at the edges, and ending in acute points, the under surface being of a paler green than the upper one, the large-leaved being the finest sort, and this kind varies from the others also, in having a dark brown-coloured bark. In this country it is a month later in expanding its blossoms than the other, and its branches commonly take a wider range while young. In its native habitat, on the borders of Lake Ontario and Lake Erie, it attains a height of eighty feet, but it has not been cultivated to any considerable extent in England. Its properties resemble those of the European species, and it is made use of in America for the figure-heads of ships on account of its fitness for the purpose of the carver.

The lime is not at all a suitable tree for bleak and exposed lands, and although we have included it under the heading of these trees which thrive best in a moist situation, it must not be understood to be such as are thoroughly saturated with water, in 
282

ENGLISH TREES AND TREE-PLANTING.

which trees of the willow tribe advance so successfully; the moisture needing to be associated with a certain degree of warmth, thriving best in a rich loam, where it will attain to a considerable size. 


\section{CHAPTER XIII.}

THE FORMATION OF PLANTATIONS.

PLANTATIONs AND PLANTING-TRAVELLTNG BEEDS OF WEED8-THE TRANBPLANTATION OF LARGE TREES-8IR HFNRY BTEWART'S MCETHOD -TRaNgPlaNtiNg MachINE-RELATIVE VALUE OF TIMBER PLANTATIONS AND AR.ABLE LAND-USUAL METHODS OF FORMING PIANTATIONS -NOTCF, OR 8LIT-PLANTING-CROSS-CUT PLAN'ING-PIT-PLANTINGTRENCHED GROUND FOR PLANTING-VARIOUS DESCRIPTIONS OF SOIL8 ALI SUITED FOR PARTICULAR TREES-ADVANTAGES OF INTERBPERBING CONIFERE IN BROAD-LEAVED PLANTATIONS-PERMANENCY OF HARDWOODED PLANTATION8.

1. The Formation of Plantations.-As plantations are formed with widely different objects, and under totally different circumstances, we will allude to each department under separate headings, which may briefly be said to comprise the planting of coniferous or deciduous timber-trees for the improvement of estates, either for the sake of their timber or the shelter they afford, comprising such trees as the oak, ash, sycamore, native Sccitch pine, spruce-fir, beech, birch, Scotch elm, larch, willow, and poplar, which we will consider under the head of plantations.

2nd. Ornamental planting, for which deciduous trees of low growth are adapted, as lilac, laburnum, acacia, several varieties of flowering thorn, mountain ash, spindle-tree, elder, willow, service-tree; varieties 


\section{ENGLISH TREES AND TREE-PLANTING.}

which make a pleasing change by their blossoms and fruit respectively ; alder, almond, hazel, wild cherry, apple, \&c., including ornamental hardy trees amongst evergreens, calculated to furnish shelter and seclusion, such as the varieties of holly, evergreen-oak, laurel, yew, juniper, arborvitæ, and cedar, of which some are well adapted to grow as underwood, under the shade of the taller trees, as the holly, yew, box, privet, common juniper, \&c.

3rd. Osier beds.

4th. Coppice, consisting of trees which are cropped, or cut down periodically before they attain the size of timber-trees.

5th. Sea-side planting, by which tracts of unprofitable land may be made productive and valuable.

Plantations and Planting.-When it is intended to form plantations on a large scale, upon an extensive tract of land, the soil will be found to vary a good deal in most instances, and while loose, deep earth will grow trees of any description, in the low-lying portions which may be moist, trees of the willow, poplar, and alder tribe should be fixed upon, to stand in such situations ; a clayey soil, or a deep clayey gravel, being suitable for the oak, which it will be best to plant interspersed with larch, the latter being a surface-rooting plant, and the former deriving its sustenance from a greater depth; and as the larch plants will grow much more quickly than the oak, they are the means of affording valuable shelter to the young oak-plants 
in a very short period; even when all are inserted at the same time.

But it is generally usual, when it is intencled to form an oak plantation in exposed situations, to plant Scotch pines and larch for shelter beforehand; the oak plants being inserted a few years afterwards, when the other trees, intended to act as nurses, have made a certain amount of progress.

In low situations, in alluvial soil, silver-fir attains to a large size, and as this tree succeeds best for the first ten years of its life, when somewhat shaded and confined, faster-growing trees, such as larch and willow, should be planted amongst the silver-fir, which admits of being planted very closely when grown alone. On account of the young silver-fir succeeding under shade, it forms an excellent tree for filling up vacancies in woods when they occur. A mixture of other trees, such as those mentioned, relieve the monotony of appearance which, without their aid, plantations present that are composed solely of deciduous trees.

On the contrary, beech is more profitably grown alone than when mixed with other trees, for having a tendency to grow branchy and become bare-headed, while the timber is only valuable when the trunks are grown tall and clean, these results are hest attained when this species stands by itself, for otherwise it is apt to prevail over its associates, and grow in an umprofitable form.

Upon poor, dry, gravelly, or chalky soils, beech, 
birch, and the family of pines succeed the best. A grood deep soil, that may not be quite fitted for some kinds of trees, will often grow Scotch elm and ash, associated together, very well : the latter inclining to land that has a tendency to moisture, botll being about equally hardy trees. In gre :nd thai is quite swampy, the larger tree-willows, $c \ldots$. ne species of poplars will be found the best, and those in sucl situations will be found to advance very rapidly.

Trees of a hardy cliaracter are needed for high altitudes, and of the broad-leaved varieties the best kinds for forming plantations will be found to consist of the mountain-asl, goat-willow, Scotch elm, ash, birch, service-tree, trembling poplar, sycamore, and alder, the latter being especially fit for the moister portions in such situations. When narrow belts are planted to give shelter to agricultural land in exposed situations, they should be always one cliain in width, and it will be found advisabie to introduce underwood in these, which will grow beneath the taller-stancings trees, as lıolly, yew, juniper, hazel, \&c.

It may readily be seen what mistakes are likely to be committed by the inexperienced planter, who does not sufficiently take into consideration these different characteristics and necessities; or the loss that must invariably ensue from ignorance of the subject, and from making choice of trees that are unfitted for the positions they are intended to occupy, and, perlaps, more ignorance exists upon the subject of treeplanting amongst farmors than in any other branch of 
st. A

r some

d. ash,

ling to

being

quite

cies of

such

high

best

consist

, ash,

e, and

coister

ts are

posed

vidtl,

cwood

nciing

ely to

who

e dif-

that

bject,

for

per-

tree-

ch of

husbandry, and yet there is scarcely a farm in England that might not be improved by the judicious planting of a few trees. This want of knowledge could often be supplemented by the expenditure of a few shillings in the purchase of a good book upon the subject; but the English farmer has been twitted with not belonging to a book-buying class; upon the approach of bad times, when it becomes necessary to economise and cut down expenses, the first item that is fixed upon being generally the discontinuance of the subscription for the agricultural journal; which would often afford him most valuable information in difficult times, by which he might often either save or make money; but it is expected that the exigencies of modern agriculture in Great Britain will raise up a class of agriculturists who are not likely to overlook such useful auxiliaries as practical works that are able to give them valuable assistance in the daily business of their lives.

Before plantations upon a large scale are formed, the land should first be carefully gone over, and the sites of future roads be mapped out, so as to afford easy access to the timber. The surface of the ground is better seen when it is bare than after it is planted; and these lines may either be formed and left vacant, or planted with a species of trees which are useful at an early age, and may be cut down when the sites need to be used for roads. Larch, willows, and poplars are best adapted for this purpose, and when felled become of value for poles, pit-timber, props, 
sheep-hurdles, and many other uses as well that they can be applied to on a farm ; and the expense, which we will refer to again, is often comparatively trifling.

Many districts that at one time possessed a memorable notoriety for their bleakness and sterility have been converted into profitable land by the shelter which trees have afforded, through increasing the warmth and fertility of a district, to which must be added the productive value of plantations of timber. It has been suggested that belts of trees act as a kind of filter to the winds, that otherwise often waft the spawn of lichens and mosses, and cover what would otherwise be fertile land with a noxious vegetation.

This view of the subject has not received as yet, from the hands of those who are qualified to make the investigation, the amount of attention which the importance of the subject deserves. In many districts it may be seen that the trees which are placed next to a marshy heath have been so fully covered with lichen on the outside, that no part of the bark was visible to the eye: while the inner trees which compose the belt, away from the immediate contact of the barren picture, are perfectly free from these parasites, and after the plantation has attained sufficient size, the land has become fit for cereal crops, which without their aid could never have been grown.

It has been noticed by careful observers that, as well as cold winds, trees appear to act as a protection, and keep off the germs of those plants which are hostile to grasses and cultivated crops. 
SE IDS OF WEEDS WAFTED BY THE WIND, 289

Travelling Seeds of Weeds.-Every one has sometime or another noticed the seed of the thistle being conveyed about and wafted by the wind-' Light as a thistle-down' as the proverb goes-so that the elements of mischief are often wafted about; and it is a well-known fact that the slovenly farmer who permits his weeds to grow, not only allows an injury to be done to himself, but is also the means of injuring his neighbour, and thus it will be seen that with shelter also comes additional fertility.

Further, when standing timber las been felled, fertile land has been occasionally known to become sterile, whenever it has been allowed to lie under grass, but with the shelter of trees the pastures have retained their greenness and freshness perpetually; and, instead of becoming deteriorated, have improved in quality by remaining a few years out of tillage.

It has been pointed out before that in many parts of Great Britain, such as are to be found in the north, in the counties of Sutherland and Caithness, the Orkney and Shetland Islands, as well as regions yet further north still, as Iceland, that the remains of large trees are found in the mosses and bogs of such districts, which give a conclusive proof that both soil and climate were adapted for the production of timber, and as the latitude has not altered since the time when these relics were at one time green and flourishing, where now hardly a shrub is to be found, and where if trees be planted they will not grow, the winds appearing to master the young plants by their 
deleterious influence, there remains the probability that if grown timber of the more hardy sorts were planted, they would be able to withstand them, and through their influence the soil again recover the degree of fertility it was once clearly possessed of, as is evidenced by vegetable remains, as both soil and climate become affected, after a long interval of exposure, to those damp and bleaching winds.

Trees of a large size can now be removed with comparative ease, by those who are willing to incur the amount of expense that is necessary to effect their transplantation, which, although comparatively heavy when placed by the side of that incurred in the planting of ycung trees, which may be purchased for five shillings per thousand, or even less, would yet be small in comparison with the large amount of good that would be effected through their instrumentality, and the gain that would ensue from a large tract of useless land lying desolate and idle being reclaimed and made fit for agricultural purposes.

The correctness of this theory has been confirmed by the evidence of many travellers in northern countries. Sir Hans Sloane, in his observations upon the bogs of Ireland, points out that a great portion of those districts which are now covered with bogs (which are entirely unprofitable, except for the small amount of winter fuel they supply to the peasantry) must at one time have been clothed with forests of trees. The wood which is now commonly found in them is made into ornaments, which are sold under 
obability rts were nem, and over the ed of, as soil and l of exred with to incur ect their ly heavy $d$ in the ased for al yet be of good entality, tract of eclaimed

onfirmed rn counupon the ortion of th bogs he small asantry) orests of found in d under

THE TRANSPLANTATION OF LARGE TREES. 291 the name of Irish bog-wood, mounted in silver or gold, the wood being very dense and hard. Sir George Mackenzic and others remark the same as being the case in Iceland; while Broke, in his 'Winter in Lapland and Sweden,' observes the same change as having taken place in the north of Lapland and the islands. Hearne, in speaking of certain parts of the American continent, remarks that large tracts of land which at the time of his visit were covered with moss and swamp, must have been standing forests in the days of the fathers of the Indians then living.

Modern writers have also observed that, in many parts of the highlands and western islands of Scotland, where scarcely a tree is now to be seen, or at most only coppice, along the shores of the lochs or arms of the sea, there are found in the soil of the bogs, not only the trunks and roots of trees of a bygone period, the same as those of which we have been speaking, from which bog-oak ornaments are made, but the roots of oaks of large dimensions standing upon the surface; nor can the period have been very remote from the time at which they were growing, for in some of the wild and almost inaccessible glens that are difficult of approach, many large trunks still lie neglected, mouldering away by the
steady eflluxion of time.

The Transplantation of Large Trees.-Trees of large size, even, can be transplanted by those who are willing to incur the expense.

Evelyn, in his 'Sylva,' speaks of the transplanta- 
tion of large trees as follows:-'Veterem arborem transplantare, to transport an old grove, was said of a difficult enterprise. Yet, before we take leave of this subject, let us show what it io possible to be effected in this kind with cost and industry. Comte Maurice, the late Governor of Brazil for the Hollanders, planted a grove near his delicious paradise of Friburgh, containing six hundred cocoa-trees of eighty years' growth, and fifty feet high to the nearest bough. These he wafted upon floats and engines four miles long, and planted them so luckily that they bore abundantly the very first year, as Gaspar Barlæus hath related in his elegant description of that prince's expedition. Nor hath this succeeded in the Indies alone ; Monsieur de Fiat, one of the mareschals of France, hath with huge oaks done the like at Fiat. Shall I yet bring you nearer home? A great person in Devon planted oaks as big as twelve oxen could draw, to supply some defect in an avenue to one of his houses, as the Right Honourable the Lord Fitzharding, late treasurer of his Majesty's household, assured me, who had himself likewise practised the removing of great oaks, by a particular address, extremely ingenious, and worthy the communication. Choose a tree as big as your thigh, remove the earth from about it, cut through all the collateral roots till, with a competent strength, you can enforce it down on one side, so as to come with your axe at the tap root; cut that off, redress your tree, and so let it stand covered about with the mould you loosened 
em arborem

was said of ke leave of ssible to be ry. Comte or the Holparadise of es of eighty the nearest and engines luckily that , as Gaspar tion of that ded in the mareschals like at Fiat. reat person oxen could to one of Lord Fitzhousehold, actised the address, exmunication. emove the lateral roots enforce it r axe at the and so let u loosened from it, till the next year, or longer, if you think good, then take it up at a fit season; it will likely have drawn new tender roots, apt to take, and suffi cient for the tree wheresoever you shall transplant it. Some are for laying bare the whole root, and then dividing it into four parts, in form of a cross, to cut away the interjacent rootlings, leaving only the cross and master roots that were spared to support the tree; then covering the pit with fresh mould, as above, after a year or two, when it has put forth and furnished the interstices you left between the cross roots with plants of new fibres and tender shoots, you may safely remove the tree itself, so soon as you have loosened and reduced the four decapitated roots, and shortened the tap roots; and this operation is done without stooping or bending the tree at all. And if, in removing it, you preserve as much of the clod about the new roots as possible, it would be much the better.

'Pliny notes it as a common thing to re-establish huge trees that liave been blown down, part of their roots torn up, and the body prostrate. To facilitate the removal of such monstrous trees for the adornment of some particular place, or for the rarity of the plant, there is this further expedient. A little before the hardest frosts surprise you, make a square trench about your tree, at such distance from the stem as you may judge sufficient for the root; dig this of competent depth, so as almost quite to undermine it, by placing blocks and quarters of wood to 
sustain the eartl ; this done, cast in as much water as may fill the trench, or at least sufficiently wet it, unless the ground were very moist before. Thus let it stand, till some very hard fiosts do bind it firmly to the roots, and then convey it to the pit prepared for its new station, which you may preserve from freezing by laying stores of warm litter in it, and so close the mould the better to the straggling fibres, placing what you take out about your new guest, to preserve it in temper. But in case the mould about it be so ponderous as not to be removed by an ordinary force, you may then raise it with a crane, or pulley, hanging between a triangle, made of three strong and tall limbs united at the top, where a pulley is fastened, as the cables are to be under the quarters which bear the earth about the roots, for by this means you may weigh up and place the whole weighty clod upon a trundle, sledge, or other carriage, to be conveyed and replanted where you please, being let down perpendicularly into the place by the help of the foresaid engine. And by this address you may transplant trees of a wonderful stature without the least disorder, and many times without topping or diminution of the liead, which is of great importance when this is practised to supply a defect, or remove a curiosity.'

Sir IIenry Stewart's Method.-Sir Henry Stewart, of Allinton, in 1816, introduced an improved method of transplanting grown timber, by which not a root was broken, the trees being prepared beforehand for removal, his plan consisting of cutting all the roots 
ch water

y wet it, Thus let firmly to pared for freezing close the placing preserve it be so ary force, , hanging and tall tened, as iich bear you may upon a eyed and eerpendiesaid enant trees disol'der, on of the this is iosity.' Stewart, method t a root land for ie roots at some distance from the tree, which in ordinary gardening operations is known to be very often advantageous to growing trees, for when the long lateral roots are cut, the stumps, if not docked too short, throw out a large quantity of young fibres, which nourish the tree more effectually than the long tap roots, upon the principle that these various roots, branching out in rıw directious, tap, as it were, new sources of supplies of nourishınent from earth that has not been previousiy taxed and drawn upon for the support of the tree during the period of its growth.

According to the plan pursued by his method, handsome, thriving trees are first chosen, that are likely to stand the operation with the least risk of damage by the operation, and the lateral roots are divided. They are then left for two or three years, in order to give them time to make fresh roots. When this has been done, the tree will then bear removal without the necessity of cutting off the top, or mutilating it. The pits for the reception of the trees have, in the mean time, been got ready; for trees about thirty feet, with trunks about a foot in diameter, a pit with a diameter of eighteen feet will be necessary. The earth at the bottom of the pits is trenched to the depth of two feet, in the course of the trenching being well mixed with a compost of a different lature to that of the soil, the ground thus prepared being all the better for lying a year or more, so as to allow the soil to become mellowed by 
time. The planting is then managed by moving the earth to a proper depth, and placing the tree in the space formed, arranging the roots as nearly as can be done in their natural position, and covering them over with the earth, and if this is well done they will stand much more firmly than might be commonly supposed.

By the system followed by Sir Henry Stewart, he was enabled during the course of five years to convert a cold, naked field into a well-arranged, wellordered park, containing objects of sylvan beauty; he gives the following account of its conversion in liis 'Planter's Guide':- 'There was in this park originally no water, and scarcely a tree or a bush on the banks and promontories of the present lake and river, for the water partakes of both these characters. During the summer of 1820 the water was introduced; and in that and the following year the grounds immediately adjoining were abundantly covered with wood, by means of the transplanting machine. Groups and single trees, grove and underwood, were introduced in every style of disposition which the subject seemed to admit. Whiere the turf recedes from, or approaches, the water, the ground is somewhat bold and irregular, although without striking features of any sort; yet the profusion of wood, scattered over a surface of moderate limits, in every form and variety, gave it an intricacy and an expression which it had never possessed before.

By the autumn of the third year only, after the 
oving the ee in the as can be ing them they will ommonly

ewart, he s to coned, wellbeauty ; ersion in lis park bush on lake and aracters. s introgrounds covered nachine. od, were lich the recedes is somestriking d, scatary form pression Iter the execution, namely, 1823, when the Committee of the Highland Society honoured the place with their inspection, the different parts seemed to harmonise with one another, and the intended effects were nearly produced. What it was wished to bring forward appeared already prominent-what was to be concealed, or thrown into the background, began to assume that station. The foreground trees, the best that could be procured, placed on the eastern bank, above the water, broke it into parts witl their spreading branches, and formed combinations which were extremely pleasing. The copse of underwood, which covers an island in the lake, and two promontories, as also an adjoining bank that terminates the distance, was seen coming down nearly to the water's edge. What was the most important of all, both trees and underwood had obtained a full and deep-coloured leaf, and health and vigour were restored to them. In a word, the whole appeared like a spot at least forty years planted.'

Transplanting Machine.-Mention is made in the foregoing of the use of the 'transplanting machine,' an invention made since the time of Evelyn, by which trees of considerable size are enabled to be renoved without much difficulty ; but, by the ordinary method of using it, which Sir Henry Stewart improved upon, the trees were subjected to a good deal of mutilation, which it took a long tine to recover from. This machine was invented by Brown, the celebrated landscape gardener, about sixty years after Evelyn's time, and consisted of two very high wheels, an axle, and a 
pole; and upon those occasions when the trees were very large, a truck-wheel was used at the end of the pole. After the tree was considerably lopped, and the earth loosened from its roots, the pole was set up erect, and lashed to the stem of the tree, and a purcliase being inade to the upper part of the pole, the whole was pulled up at once, by sheer force, and afterwards drawi horizontally along to the place where the tree was to stand.

In Scotland and Ireland; it cannot be doubted but that the extinction of forests and the cutting dowl of timber have often been productive of varied climatic and other changes, as well as in connection with the nigration of birds and animals.

In a recent work by Mr. J. A. Harvey Brown upon the Capercaillie in Scotland, more commonly called the capercailzie, the history of the extinction and restoration of this fine bird is given, which was once one of the commonest birds in Scotland, and became extinct about 1762 , when it was last seen in the policies of Kirkmichael, Banffshire. Reference is made to the many theories which have been started as to the cause of its extinction, the author giving the one now most generally adopted, attributing the most likely features in the extirpation of the bird to be the destruction of great forests by tracks of fire, their being cut down by man as late as the days of Crom. well, their wasting away from natural causes, and their conversion into bogs; all resulting in the decrease and change of the food of the species, the 


\section{RESTORATION OF CAPERCAILLE INTO SCOTLAND. 299}

ees were

dd of the sed, and is set up d a purpole, the nd aftere where

ted but down of climatic with the

vn upon called on and as once beeame te polinade to to the ne now likely be the their Crom$\mathrm{s}$, and n the es, the loss of this wood having now been chiefly supplied by the replanting which began at the beginning of the eighteenth century, which, although coming too late to revive the dying species, has aided most materially in its restoration.

To lovers of sport, it may be interesting to add that the first attempts to restore the capercaillie into the sister kingdom appear to have been made in 1827, when a male bird was safely brought from Sweden, followed by a cock and hen in 1829 ; since then the work has gone on steadily, the largest importation being that which arrived in Taymouth in 1837-38, when, according to some accounts, there were forty-eight, and to others fifty-four, full-grown capercaillie received alive; since then the extension of the range of the bird has considerably increased, having been seen as far north as Blair Athole; as far east as Brechin ; as far sonth as Falkirk; and westwards as far as Dalmally, the most considerable extension having taken place eastwards along the valley of the Tay.

Relative Value of Timber Plantations and Arable Land.-At this particular time, when these lines are being written (at the end of the year 1879), there is a great discussion going on as to the unprofitable nature of arable land in some districts, and in these cases the planting of trees to a great extent has been suggested by some.

A calculation was made some years ago with reference to a plantation of ash, and it was found 
that it took thirty-seven years to produce a load of timber containing forty cubic feet, which at 1.s. $3 d$. per foot, realised $2 l$. 10s. Ninety trees per ace at this rate produced $225 l$, the price yielded by the brushwood, hop-poles, and thimmings at varions times paying the cost of looking after the yommg trees, and the final expense of felling, de. The land might have been let at $2 l$. per acre, which for thirty-seven yeurs, at five per cont. compound interest, would have realised ahout $203 l$, so that the gain was rather in favom of the trees.

Usuenl Methods of forming Plantations.-On accomnt of diflerence of sitnation, diflerence of soil, and the herbage which overspreads it, the methods of forming plantations are very diversified. 'The description of plants to be used will depend npon soil and exposnre, and the size of the plants thenselves must in turn depend npon what is aheady growing upon the land, and whether they will have to perform the duty of extirpating a rank herbage, or not, in the former ease strong plants being necessary.

Notch, or slit-phlenting.-In Scotland, a very expeditions and chenp method of planting is followed, that appears to be very little known or practised in England, which is called the notch, or slit-planting, system. This operation is performed by a small planting spade, or hand iron, the blade of which is about seven inches long, and its entire length about one and a half feet, and weighing something near two and a half pounds. This implement is struck 
a load 1.s. $3 d$. acre at by the is timey ees, and mighlit y-seven ld have ther in

On ac:of soil, acthorls 'Ihe

lipon thenlalready ll have age, or essilly. y expellowed, ised in lanting, small hich is about g near struck into the ground in a slunting direction with one hand, which causes it to penetrate more easily than when applied perpendicularly, the plant being inserted with the other, the planter having a bag tied round lis waist to loold the plants in, which he quickly takes from it. The tree is inserted in the ground on the further side of the hamd iron, and by giving it a twist, an openiag is made in the turf to receive the roots, a stamp of tice foot is then given upon the laised turf, which makes the whole firm, and the job is complete. An idea of the rapidity with which this operation can be done may be formed from the fact that, in a smooth, soft, lieath soil, a practised planter will insert from 3000 to 4000 plants with the hand iron, in one working day.

$\Lambda$ s well as being the most speedy and economical, it is also the nost successful, upon ground adapted for the system; which best applies to a dry, sandy, or gravelly moorland, with plants four or five inches in height, such as Scoteh pines and spruce that are twoyear-old seedlings, or that have been one year transplanted from the seed-bed ; for larches, either one- or two-year-old seedlings, or one year transplanted, and in othe: plants not exceding the age and height named.

This plan, or method, without any previous preparation of the land to fit it for the reception of the plants, would be regarded by most English planters as a very slovenly and inefficient one, in most instances ; but the fact is, the standing heath, when only of a 
moderate size, is more favourable to the growth of the young plant than if inserted upon a bare prepared surface, as its cover affords a great protection to the young plant; and while its roots do not injure them the same as those of a grassy vegretation, its open stems do not retain sufficient moistare to rot the plants.

The ordinary kind of moorland, situated at a considerable altitude, is not so well adapted for the growth of plants when it has undergone a certain amount of preparation as when left alone and undisturbed, on account of the pulverised portions being deprived of the shelter of the heath ; for those places absorb an excess of moisture which occasions the ground to swell during frost, and subside again in open weather, which causes the plants to be ejected: moor or peat ground being naturally apt to contract and shrink during the summer. By making merely the notch, or slit, with the planting iron, there is not the risk of the soil opening with its attendant cover on it, by which the roots are exposed at a time when they are most likely to be injured. This is so well understood by men of experience in these districts that if, in the progress of slit-planting, they come to a bare spot with a broken surface, they will move on to the nearest point endowed with a heathy sward, into which they will insert the plant.

In those extensive tracts of heath-land where this method of planting is followed upon an extensive scale, the plan is, to have a number of men who each advance regularly and keep at an exact distance from his 
owth of rrepared $\mathrm{n}$ to the re them en stems ants.

ed at a for the certain d undisas being e places ons the gain in jected : ontract merely e is not it cover e when so well listricts me to a e on to d, into ere this e scale, dvance m his neighbour, which is regulated by that at which the plants have to stand from each other. An overseer is appointed to every dozen men, to see that the work is done properly, and to keep pace with those who are more expeditious at the work, who are sometimes likely to leave the others behind them; for although an active, good workman is much to be desired, his superior exertions sometimes cause the more sluggish ones to scamp their work who are following him, who are ambitious of emulating his. progress, so far as appearances only are concerned, but do not perform their task thoroughly.

This method is, however, not practised with plants of great size, which are needed for rough ground when the heath is rank, and there is a heavy cover.

Cross-cut Planting.- Where the herbage is tall and rank, the method termed 'cross-cut planting' will be found the most appropriate, which consists of forming a slit with a common spade, in the first place, and then making a cross slit near to one end, the surface soil being raised, the plant inserted in the corner, and the soil pressed down with the foot. The spade needs to be a well-worn one, that has a sharp edge, and two-year-old seedlings which have stood one year in nursery lines of Scotch pine and larch, or two-yearold transplanted spruce, are needed for subduing coarse herbage that overspreads a soft soil, the plants always being large in proportion to the herbage they have to contend with, and if there is danger of this choking the plant, it should be cut away from the spot 


\section{ENGLISH TREES AND TREE-PLANTING.}

where the young tree is destined to stand; and on close and grassy soils a spadeful should be turned sver before the plant is inserted, and as those that are so treated have to be of a larger size, there is not that danger, as in the case of the smaller ones, of being ejected when the fine weather succeeds frost. That young plants are so ejected in bare ground is amply proved by the case of the native-grown forests, young plants never being found springing up in the bare spots, but associated with the brown heath they grow spontaneously, without any artificial aid, and in these cases a distinction must be drawn in the necessary course to pursue, in accordance with the nature of the cover on the land, which will cause it to be better adapted respectively for the notch system or the crosscut plan.

In making plantations, a description of land is often come upon where the surface is covered with a short sward of grasses and close-matted herbage. This is not nearly so favourable a soil to deal with as one covered with brown heath; and if plants are inserted in such land upon the notch system, the turf needs to be removed from the site where each plant is to stand, to about the depth of a couple of inches, and after the plant is notched into the ground the turf should be broken and placed around the stem of the plant, with the grass side downwards, and should the soil, as is commonly the case, be a stiff clay beneath, it should be loosened by a stroke or two of the pick before the plant is inserted. 
and on ned' sver it are so not that of being t. That is amply $\mathrm{s}$, young the bare iey grow in these ccessary re of the e better he cross-

is often a short This is as one inserted needs to it is to hes, and the turf $n$ of the ould the veneath, the pick

In ground of this description another plan is followed, which takes up more time, it is true, but is generally considered the most complete, which consists in digging over a spadeful where each plant is to stand during the summer or autumn, and inserting the young tree in the following spring.

Planting with the common spade by the cross-cut method is thus necessarily much more expensive than the slit-planting system, as the land has to be prepared for the insertion of the young tree by one man, while another plants it, and firmly establishes it in its proper position; the expense being still greater where the soil needs to be broken by the pick, or dug over by the spads.

Many of the moorland plantations in Scotland have been formed at a comparatively small expense, the number and description of plants inserted liaving been regulated by the amount of exposure ; in elevated situations, larch, spruce, and Scotch pine liaving been most profitably grown. When the land was rough and bare, 5,000 plants per acre have sometimes been used, which allows of a space of rather less than a yard for each to stand in. But in more sheltered situations, where the ground has been relied upon for the plants to take root, 3,000 have been found sufficient, a common proportion allotted being one-third of larch to two-thirds of Scotch pine, regularly mixed, so that when the plantation needs to be thinned out it may be made to consist of either all of one sort, or an admixture of both, according to circumstances, which 
are regulated by the quality of the soil, and which kind bids the fairest to turn out most profitably. The larch is unfortunately subject to a good many casualties, unless planted upon safe ground; but where it thrives it can be grown more profitably than any other tree, and it succeeds best on the slopes of ravines, on the alluvial banks of rivers, and in those situations where the soil, though it may be somewhat moist, is yet entirely free from stagnant water. The Scotch pine will grow anywhere, however dry the land may be, after it has once taken root.

Spruce firs succeed also in the same kind of soil which is most suitable for larch, although not so well adapted for a high altitude; and they can be planted much closer than larch, and the trifling cost at which a good deal of planting has been done in North Britain would astonish many a 'southerner'; for a large acreage has been covered with thriving Scotch pine and larch, at a cost for labour and trees which las not exceeded $12 s .3 \mathrm{~d}$. per imperial acre: this, of course, having been done upon the cheapest principle, that of 'notching,' in a good moorland, with a herbage of appropriate beath, the calculations being as follows :-

3,000 two-year seedling native Scotch pine at

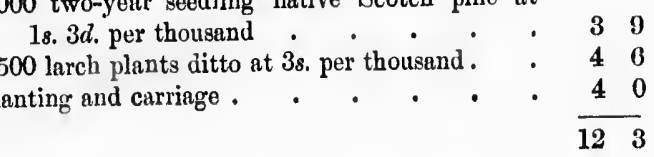

- There are many proprictors of umprofitable, sandy 
nd which

bly. The

ny casualwhere it any other avines, on situations moist, is he Scotch land may nd of soil ot so well ye planted $t$ at which in North er'; for a ng Scotch rees which e: this, of pest prinnd, with a ions being

๖. d.

39

40

40

$\overline{123}$

able, sandy land in the southern districts of England who have never given the subject of tree-planting sufficient attention, who would be very pleased, doubtless, to have improvements effected by these means, upon such easy terms or at approximate rates, and there is nothing to prevent them from having it done, for upon such spots as a grassy heath, where stouter plants are necessary, by the Scotch plan of the use of the planting iron, the calculation is usually made to stand thus :-

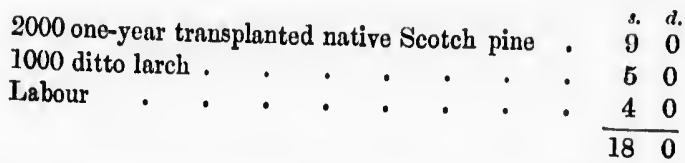

To this calculation the cost of carriage must be added, but thousands of acres have been planted in Scotland at an expense not exceeding an average of fifteen shillings per acre, even where a much higher cost has had to be incurred in places on account of the nature of the soil that has had to be dealt with, as, for example, where the ground has been covered with rank herbage, but adapted for being notched with the common garden spade, the expense of which has been estimated as follows :-

2,000 two-year transplanted native Scotch pine 1,000 one-year ditto larch $\dot{0} \cdot \quad$. 0160

Planting, at $78 . \quad$ • $\quad 068$

$$
\begin{array}{lll}
0 & 7 & 0 \\
\hline 1 & 9 & 0
\end{array}
$$

In Scotland, in moorland districts, seedling pines × 2 
and larches are more commonly used than the transplanted plants, though in exposed and bare grounds the one-year-old seedling Scotch pine, one year transplanted, seldom fails, and is very tenacious of life, which brings down the cost of the trees, and the expense of planting, when operations are performed to any extent, including those of draining and fencing, to a low sum, which seldom exceeds one pound per acre.

Some of the Scotch nurserymen grow trees upon a large scale that are thoroughly adapted for every kind of soil by previous preparation, the success of forest-planting much depending upon the quality of the plants, the prices of certain kinds varying according to the amount of trouble and labour that has been bestowed upon them, the following being about the usual scale for large quantities, plants that have stood two years in nursery lines-

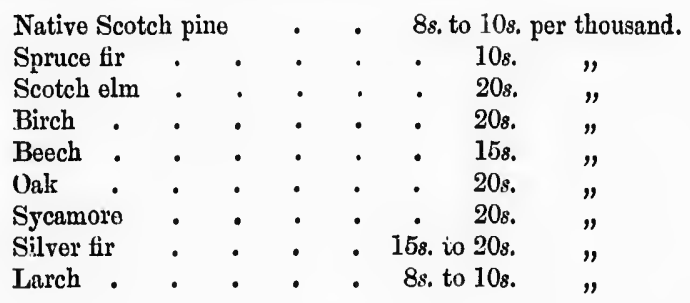

As a rule, two-year-old transplanted plants are the best to employ, for although those which have stood for three or four years in the nursery lines appear the stronger and better plants, they do not succeed so well, and very seldom grow freely for the first year or two after having been planted, the 
he transgrounds ne year acious of and the ormed to ncing, to per acre. ees upon or every iccess of ality of accordthat has ig about lat have and.

ants are ch have ary lines do not 'eely for' ited, the reason of this being that their roots are deficient of that fibrous bushiness upon which the success of a transplanted tree mainly depends, and which can only be insured by repeated transplantation, save in certain exceptional instances.

Pit-planting.-Upon deep, rich, and more sheltered soils, fitted for the reception of broad-leaved timbertrees, the system of pit-planting is commonly adopted, the pits being made a few months before the plants are inserted, which are usually two-year-transplanted hard-wooded trees. Pits are mostly made a foot and a half wide by fifteen inches deep; but the more capacious the pit, the better for the future tree, as its roots can be more effectually spread, and they enjoy a freer soil, into which they can strike in search of their proper nutriment. On this account, when the soil is hard, the bottom of the pit should be loosened with the pick.

After the bottom of the pit has been made quite soft, the surface sward should be chopped up and filled in first, and then covered to the depth of five or six inches with the excavated soil. By the time the plants come to be inserted a few months afterwards, the surface sward will have become considerably decayed, the planting being usually performed in dry and moderately sheltered ground in the beginning of winter; but in moist and exposed ground, at the beginning of spring. A man and a boy are usually paired off together for pit-planting; the man first taking out a spadeful or two of the earth 
that has been cast into the pit in the course of the preceding summer, while the boy afterwards holds the tree in position, and sees that the roots are properly spread and surrounded with soil, while the man fills in the pit. The plant should be inserted in the ground about an inch deeper than it stood in the nursery lines, which will be indicated by the soilmark round its stem, care being taken that the plant stands perpendicularly, when the earth should be well stamped down with the feet around it.

In a dry soil it will be found of great advantage to leave a concavity round the plant, which will retain the moisture and greatly assist in establishing it, though the reverse practice may often be seen to be followed, and the young tree left standing, as it were, on the summit of a little mound, which has the effect of shooting off the moisture to a distance, instead of reaching the roots of the growing plant, and upon the slopes of hillsides this principle is more than ever necessary to be observed, and the outer or under edge of the pit should be formed sufficiently high to intercept the rain, which otherwise would be apt to run down the hillside and escape, without performing the friendly office of which it is capable.

Trenched Ground for Planting.-Although, as previously shown, coniferous trees succeed best in ground that has been undisturbed when covered with a suitable heath, if not of too coarse description, yet for plantations of hard-wooded trees in lower situations, and in soil of a different description, no plantations 
of the ls holds are prothe man $\mathrm{d}$ in the 1 in the he soilhe plant ould be

vantage will reshing it, in to be it were, he effect tead of pon the an ever ler edge to interto run ing the igh, as best in ed with , yet for uations, atations succeed so well as those which have been established in trenched land, the ordinary calculation being that trees of this description will advance as rapidly in six years as in ten years in untrenched land. Some soils, especially dry, sandy ones, are covered with a matted herbage, consisting of the fescues and other wild grasses, which intercept the beneficial influence of the showers, the depth of its roots intercepting and appropriating the nourishment that would otherwise be enjoyed by the young trees.

The trenching thus greatly adds to the vigour of the young plantation, and where the subsoil is of inferior quality, it is better to bring it up to the surface. Ploughing, or even one-spit ordinary digging, is very inferior to trenching, as the roots of trees penetrate to a considerable depth, and a loose soil at bottom is necessarily of great advantage. The trenching should be done two spits deep, and this may even be improved upon, by thrusting a strong fork down into the lower strata, and giving it a kind of twist or lever turn with the hand and wrist. Expense-the cost of manual labour is the reason why this method is not more generally followed, but this will be found to be by no means all extra outlay. It is always necessary to keep the surface of young plantations clear from weeds for the first two or three years after planting, and the cost of doing this is considerably less upon trenched ground than upon ploughed land; and the expense of trenching has often been recouped by a heavy crop of potatoes, which like 
fresh ground, or other roots, such as carrots, which will bring a very heavy crop in some kinds of sandy soils.

Furze is not unfrequently found growing upon land that is excellently well adapted for the growth of timber, and this may be dealt with by first cutting the furze down, and then trenching the land; or by rooting up the furze, and pit-planting young trees of a suitable description. Larch is a valuable agent for extirpating furze, and when it is the intention to have a plantation of a different order of trees, yet it will be found advisable to intersperse the other trees thickly with larch, although they have to be removed after they have sm, thered the native cover by the confinement they have caused.

Upon those sites where timber has already stood, which does not produce shoots from the roots, as larch and Scotch pine, the only effectual way of dealing with the hard soil, and fibrous interlacing of the old roots, is by trenching, which otherwise would ordinarily require from eight to ten years to rot before the ground would be in suitable condition for the growth of another crop. Birch, oak, and the various species of the willow are the best kinds of trees to form a cover for the ground, after timber has been felled, birch very often springing spontaneously after Scotch pine; but when plantations are to be continued, it is the best plan to insert in spots of ground that have been duly prepared beforehand, birch, beech, oak, willow, or whatever kind of trees 
is, which of sandy

ng upon growth cutting ; or by trees of gent for to have $t$ it will er trees removed by the y stood, coots, as way of acing of e would rot betion for and the kinds of iber has ineously e to be spots of rehand, of trees may be decided upon, before the removal of the old timber, when it will be ready to take its place.

Various Descriptions of Soils suited for Particular. Trees.-Almost any kind of soil will grow different kinds of trees, which will attain to a considerable size; and in forming plantations, it is well to keep in mind, as nearly and as closely as possible, what description of trees would pay best to grow and suit the local demand and consumption, and the distance at which broad-leaved trees are planted depends very much upon the value of the young timber in the neighbourhood. In almost all the northern parts of the kingdom, beginning at Leicester, in the Midland counties, and proceeding northwards as far as Aberdeen, there is always a demand for wood for the purpose of making bobbins, that are used in the manufacturing districts, and since the invention of the sewing-machine, more especially, the demand for reels for sewing cotton has been very great, and young timber suited for this purpose is often very valuable.

About 1,500 plants of the broad-leaved varieties, per acre, are very commonly used, with about an equal number of larches, firs, or any other variety to be first thinned out; thus placing the young trees about four feet apart: but sometimes only 1,000 per acre are used of the more valuable hard-woorled trees, which allows a distance of about eight feet and a half between each, and 2,000 of the quicker-growing kinds, to be removed early, as the plantation proceeds in its 
course of growth, this applying more particularly to tolerably sheltered situations.

In cold, rough, exposed situations, thicker pianting is, however, found more desirable, as well as in those places where the surface soil is covered with furze. By planting larches pretty thickly, they will generally manage to extirpate this growth, as well as other herbage that requires to be subdued; and show the useful effects of thus alternating with hard-wooded trees, plants of two-year-transplanted larches and Scotch pine, as before recommended, allowing the plants to stand only about three and a half feet asunder.

If the ground has been well grubbed and carefully planted, in most cases the undergrowth of objectionable herbage will give but little trouble; yet it occasionally happens that it becomes necessary to examine the plantations in about three years' time, and cut out any that are likely to outgrow the treeplants. The danger of this occurring will, however, be considerably lessened if, at the time of cutting the furze, the stems are cut over with the bill, or hook, close to the surface of the ground, and the tops regularly spread over the roots, it will thus form a close cover, and so confine them as greatly to check the development of any further undergrowth that is likely to prove injurious.

A somewhat similar method is also found to be efficacious in the case of fern, which rises to a great height in some districts, and without proper care is 
ularly to

er piantell as in red with they will well as nd show -wooded hes and ving the alf feet

nd careof obble ; yet ssary to 's' time, he treelowever, ting the or hook, ps regua close eck the that is

$d$ to be a great care is sometimes apt to prevail over young plantations; for when these are cut down, they quickly spring up again, and produce fresh shoots, and it is found the better plan to break over the stems, and bend the Jeaves down to the surface of the ground, in those situations where there is any chance of their overtopping the young plants; fern prevails to a great extent in some of the sandy districts of the southeastern counties, as well as in the more humid ones of the western counties of England.

Advantages of Interspersing Coniferce in Broadleaved Plantations. - Besides the advantage of subduing an objectionable surface herbage, when trees of the coniferous order are planted with hard-wooded trees of a more valuable kind, they act as nurses, and supply an amount of shelter that is extremely favourable to the progress of the slower-growing varieties of trees. As well, they are the occasion of preventing them from acquiring a bushy form, and cause the boles to run up tall and straight, which is a very valuable feature in a timber-tree, and healtlyy plants will generally advance with leading shoots, so that in close plantations there is seldom anything more required than judicious thinning, where otherwise a good deal of trouble might have to be incurred in pruning, an operation that is only very imperfectly understood by many woodmen, the production of timber being always more effectually managed by the unaided operations of nature, the leading shoots being forced upwards by their natural endeavours to 
get air and light, and so a clean trunk is grown, free from large knots and imperfections.

In naturally formed forests, where trees of all sizes and ages may be seen growing together, although the strongest prevail, and confine the proportions of the weaker trees, yet the latter in turn perform a very useful office to the former, for they subdue the progress and check the strength of their side branches, which are gently pressed by the weaker trees, and cause them to form cleaner boles than otherwise would have been the case.

Thinning Plantations.-Thinning is an operation that demands care and judgment, and needs to be done pretty early, in those situations where the trees have been closely planted for the sake of shelter; and these thinnings are often of considerable service for agricultural uses of one kind or another; but it

$\checkmark \quad$ is when the trees begin to grow tail and feeble, their height outstripping a proportionate girth, that thinning becomes incumbent; and it is at this period that the exercise of sound judgment is necessary, is some kinds endure confinement better than others; as, for example, pines will allow of closer crowding than larch, and when the latter grow vigorously in a mixed plantation, it is betier to allow the strongest to stand along the outsides, and also by the different openings, as they will grow into value, and make satisfactory progress in those positions; the larch requiring $a$. large amount of foliage to mature healthy and sound wood. This is, indeed, the case, 
rown, free

ees of all gether, althe pror in turn , for they h of their he weaker oles than

operation eds to be the trees f shelter ; le service ; ; but it eble, their hat thineriod that , its some 's ; as, for ling than usly in a strongest different nd make he larch mature the case, more or less, with every description of tree, but with the larch in particular, and many ignorant foresters complacently lop away the lateral branches of trees, leaving only a bare trunk, thinking thereby they are developing its growth; but the strength of trees is maintained as much through the instrumentality of their branches and leaves as from the root, and in pruning every tree a due proportion of side branches should always be left, to promote its healthy growth and progress.

It has been estimated that larch plantations, at the age of forty years, should contain from 200 to 250 trees per acre, when they are supposed to be worth about $100 l$. per acre, the previous thinnings having paid an equivalent for the rent of the land, and every expense incurred in the formation of the plantation; but the value of timber varies a good deal, though these thinnings of the young trees do not, being always in demand for certain purposes, in the neighbourhood of coal mines especially, being much in request for pit timber; and when larch is interspersed with oak, in a suitable soil, it has been reckoned to pay a greater profit than can be obtained from any agricultural crop. It is also a great improver of the soil, which is always covered with a fine, grassy surface beneath larch, well adapted for cattle and young stock, that may often be turned into larch plantations, when the trees have attained a sufficient size to place them beyond the reach of injury. 


\section{ENGLISI TREES AND TREE-PLANTING.}

As a tree to be ultimately thinned out, the Scotch pine does not incrense its cubical contents with the same rapidity an the larch, except in those instances where the soil is not congenial to the growth of the latter. When this turns out to be the case, the larel can be cleared out in the early thimnings. I'ine plantations at the age of thirty years are generally allowed to stand at the rate of 700 or 800 per acre, which allows a distance of seven or eight feet from tree to tree, and after this it is usual to fell about 100 trees per acre, every four or five years afterwards; regulating the admission of air and light in proper proportions. Unless Scotch pines are kept pretty close, they are apt to become branchy, and less valuable as timber, requiring a somewhate opposite treatment to 'arch.

It sometimes happens that, in thinning a plantation composed of hard-wooded trees and mixed trees, a Scotch pine, or some other variety of tree that has been inserted for shelter, presses too closely upon the more valuable tree; and yet the shelter it affords cannot well be dispensed with. Under these circumstances, the branches on the side of the tree which press too closely on its more important neighbour should be removed, and the tree itself at a subsequent thinning, when it has fully performed its office of nurse, and there is no longer occasion for its services being retained.

The distance that broad--leaved trees should stand apart will depend at times upon their situation. In 
e Scotch with the instances ho of the the larch s. P'ine renerally oer acre, eet from ll about rs afterlight in ore kept chy, and c oppo-

plantaed trees, ree that ly upon affords circume which ighbour subsets office for its d stand on. In belts, they admit of being placed much closer together than when in the depth of the forest; for so situated, they enjoy a much lareror proportion of air and light. It is commonly estimated that thinnings slould commence in a plantation of trees standing four feet apart from one another, when they attain a height of twelve or fifteen feet, the inferior trees which press too closely upon the others being removed; and by the time they are twenty feet high, lialf the number originally planted should liave been removed. At a height of thirty feet, they should stand apart fully seven feet upon an average, standing at about the rate of 800 to the acre. When at a height of forty feet, which is usually attained in about the same number of years, the trunks which will have run up tall will require the addition of girth to produce valuable timber; and at this stage, space must be left in the full development of the foliage of the trees, and this is generally estimated to be obtaincd when they stand about a dozen feet asunder, or at the rate of 300 trees, or ratler nore, to the acre.

We have mentioned forty years a it period when broad-leaved trees will have attained a considerable size, but the tree-willows and poplars will make as 11 h progress in twenty year's, in a rich, soft, moist soil, as the lard-wooded varieties do in forty years. Beech is a tree that sliould not be made use of, to intersperse anongst other trees in a plantation, but should be planted in groups by itsclf, 
where the object is the obtaining of good timber. Although luxuriously in a deep, rich, dry soil, it succeds better than any other hard-wooded tree in dry soils of inferior qualities, being especially well adapted for cultivation in calcarcous soils. Planted singly, the beech is apt to ramify near the ground, and although, when in this form, its appearance is very ornamental as a park or lawn tree, its timber is only valuable when produced in great lengths; and when planted somewhat thickly together, beech-trees may be grown fifty to sixty feet in height, with a clean trumk; the entire height of such trees being 100 feet, when they have been kept close enough during their early progress, to prevent the spreading of their lateral branches.

At the age of forty years, an acre of elm, ash, or sycamore is generally found to contain from 2,500 to 3,000 cubical feet of timber ; but at the age of sixty years the amount of measurable timber will be doubled. The ash is more commonly grown in the southern counties of England than either elm (Scotch) or sycamore, which are more commonly found in North Britain. The oak grows at a slower rate than the three kinds mentioned, but as it springs from the stools of trees that have been felled, and thus forms excellent coppice, its growth and yield on the whole may be said to equal that of the other varieties. It will be as well to remark here, that when oak-trees are felled, or any other kind of tree which springs from the root, the top of the stools 


\section{PERMANENCY OF MARD-WOODED PLANTATIONS. 321}

should be formed into a convex shape by the axe in order to prevent the surface from retaining water, which is otherwise calculated to injure it.

Permanency of Hard-uooded Plantations.-Plantations of hard-wooded trees are generally permanent; up to eighty years the spaces being gradually widened, to allow of the proper development of the largest trees. But long before this period is reached, plantations of broad-leaved trees become very irregular as regards the size of the timber, and in the relative distances which the trees occupy to each other, which is caused by the growth of stools that produce saplings which occupy degrees of space proportionate to their size and strength, upon all sides young trees being in the course of springing up that will ultimately be able to take the place of the larger trees that are felled from time to time; in this respect differing from larch or pine woods, which are gradually felled, and cleared entirely away, at successive stages of their growth. The selection of the varieties of trees, however, to form plantations is seldom a matter of choice, but becomes one of expediency, or necessity, when the best possible results are sought to be obtained in a course of treeplanting managed in accordance with the best known principles for insuring the largest amount of profit. 


\title{
CHAPTER XIV.
}

\author{
ORNAMENTAL PLANTING.
}

LILAC-LABURNOM : CULTIVATION-ALMOND: CULTIVATION-THE LARGEFRUITED ALMOND-THE HAZEL: CULTIVATION-UNPROFITABLE FILBGRT PLANTATION MADE PROFitable-CONSTANTINOPLE HAZEL-THE IIAWTHORN : CULTIVATION.

IN the formation of ornamental plantations it is, of course, desirable to produce an immediate effect, and this can be obtained by making use of trees that lave been frequently transplanted into nursery lines, by which the bushiness of the roots (repeatedly referred to before), essential for their successful establishment, has been encouraged and developed; some trees, as the horse-chesnut, arlmitting of removal when of considerable size, if these precautions have been taken beforehand. This is one very important point, and another consists of making choice of trees which are suited for the aspect, soil, and shelter they will have to endure.

Some kinds of trees are well adapted to furnish shelter to others in the form of narrow, outside belts, as several varieties of holly, evergreen-oak, yew, juniper, laurel, arbor vitx, cedar, \&c. ; and in situations of great exposure, where there are natural difficulties to be overcome before trees can be suc- 
cessfully planted, the common and scarlet elder, mountain ash, Scotch pine, aspen, sycamore, service-tree, laburnum-with its graceful clusters of drooping yellow flowers-beech and birch, are all
appropriate.

Beneath the shade of any of these may be planted, in the form of underwood, box, yew, privet, holly, and juniper, which are all evergreens, so that there need not be any bare places; and the dark green foliage of most of these causes a plantation to wear an air of seclusion and shelter, which could not be given by the deciduous trees of low growth adapted for plantations that are of an ornamental description, such as many varieties of thorn, which are very pleasing to the eye, both in the season of blossom and fruit, acacia, laburnum, lilac (the two latter forming an agreeable contrast of colour in their blossoms when associated together), almond, elder, hazel, cherry, spindle-tree, willow, apple, maple, service-tree, \&c.

When a perfect effect is sought for, in warm situations upon an open border, a great finish is obtained by making use of some of the plants of the natural family Solanea, to which the love-apple, or tomata, and the egg-plant belong. Though the young plants require to be forwarded in a hot-bed, they may be made to produce fruit in warm and sheltered
borders.

The tomata is too well known to need description, but both the round and the long variety of the white egg-plant (the Solamem melongenn of Linneus) are 
cultivated in the garden of the Horticultural Society, the plants, which are annuals, being first raised to the height of nine or ten inches in the stove, and then planted in the borders in the open air, where they grow to the height of two or three feet. The fruits of both kinds are large, that of the long sometimes measuring eight inches in length.

To this tribe, it may incidentally be remarked, belongs the Solanum Sodomeum, or Dead Sea apple-

Dead Sea fruits, that tempt the eye,

But turn to ashes on the lips-

which has been so celebrated in fabulous history, and perplexing in true, that is found upon the borders of the Dead Sea, whose desolation causes it to be a fit locality for the exercise of superstitious terrors in connection with the dreadful judgment visited upon the cities of the plain recorded in Biblical history.

Of these apples Josephus, the Jewish historian, says:- They have a fair colour, as if they were fit to be eaten ; but if you pluck them with your hand, they vanish into smoke and ashes.'

The Solanum Sodomeum is, indeed, a purple eggplant, witl large, handsome fruit; a species of cynips sometimes attacking and puncturing the rind, upon which the inside gangrenes, and is changed into a substance like ashes, the outside continuing to preserve its beautiful appearance.

Henry Teonge, a chaplain in the English fleet. states that he saw these 'apples' in 1675, and gives a 
Society, sed to the and then here they The fruits sometimes

emarked, a apple-

tory, and borders it to be a errors in ted upon istory. historian, were fit our hand, rple eggof cynips ind, upon d into a s to prelish fleet. d gives a correct description of their decayed condition. The country about the Dead Sea, says he, 'is altogether unfruitfull, being all over full of stones, which look just like burnt syndurs. And on some low shrubbs there grow small round things, which are called apples, but no witt like them. They are somewhat fayre to look at, but touch them and they moulder all to black ashes, like soote, boath for looks and smell.'

Pocock, a later traveller, though he makes mention of the Dead Sea fruit, and alludes to their popular description, says, 'I saw nothing of them; but, from the testimony we have, something of the kind has been produced. But I imagine they may be pomegranates, which, having a tough, hard rind, the inside may be dried to dust, and the outside remain firm.'

Other travellers also, upon whom the account of these 'apples ' had made a deep impression, and tried to procure some specimens, met with disappointment, as in the case of Marati, who writes- No person could point out to me in the neighbourhood that species of fruit called the apples of Sodom, which, being fresh and of a beautiful colour in appearance, fall to dust as soon as they are touched.'

These apples, associated with the mysterious Dead Sea, in whose bitter waters no fish can live, with bitumen, and sometimes, as it has been reported, with smoke issuing from its surface, have piqued the interest of many writers and travellers ; but Hasselquist 
not only found the apples, but pointed out the cause of the disease.

Milton refers to these apples as adding to the anguish of the fallen angels after their transformation upon Satan's return from the temptation of Eve.

A giove hard by,

There stood

- . laden with fair fruit, like that

Which grew in Paradise, the bait of Eve,

Us'd by the 'Tempter: on that prospect strange

Their earnest eyes they fix'd, imagining,

For one forbidden tree, a multitude.

The fruitage fair to sight, like that which grew

Near that bituminous lake, where Sodom placed;

This more delusive, not the touch but taste

Deceives; they fondly thinking to allay

Thoir thirst with gust, instead of fruit

Chew'd bitter ashes, which the offended taste

With sputtering noise rejected.

Although not coming exactly under the heading of tree-planting, being allied to gardening operations, those who are desirous of doing so, may raise plants of the Solanum Sodomeum by sowing the seeds in a rich hot-bed, which, about the middle of May, will produce plants fit to be transplanted to a warm sunny border; and, if properly cared for, the fruit will ripen in August.

When trees are required of great size, for park decoration or similar positions, the common and purple beech, British and scarlet American oaks, planetree of various kinds, Indian cedar, the cedar of Lebanon, lime-tree, elms of different kinds, and 
the cause

ig to the formation Eve.

heading perations, ise plants seeds in a May, will Irim sunny will ripen , for park and puris, planecedar of nds, and especially the horse-chesnut, are all very handsome and appropriate ones to make use of.

The soil which is to form the site of ornamental plantations should always be first well trenched and exposed to the frosts of winter, in order that the clods may be well pulverised; the trenching to be done two feet deep, and if the under soil is of inferior quality, it is better to place it upon the surface. If well-manured and cropped beforeliand with potatoes, the crop will prove valuable for its own sake; and also be found an excellent preparation for the reeeption of young trees, and the surface is made thoroughly clear of weeds, that often spring up freely, but which the potato-crop will effectually smother.

The ground properly prepared, the ornamental effect of plantations is much increased by the tasteful arrangement and grouping of trees which possess a distinguishing appearance at different times of the year. The most conspicuous varieties for ornamental effect in autumn are the red and scarlet American oaks, the species of maple that comprehend specimens of various sizes, which are all extremely handsome, excepting the sycamore, which is a somewhat plain-looking tree, though imposing on account of its size; wild cherry, aspen, and numerous other trees, of which a description will be found given, each under its proper title.

In ornamentai plantations evergreens always play a very prominent part, of the varieties spoken of 
before, such as laurel, box, juniper, arbutus, $y^{`} v$, and evergreen oak, or ilex. Evergreens are best transplanted in September, though many writers recommend another time of year; but it has got to be understood that at this season the plant is not in quite a dormant state, and if means are taken to prevent the ruots from exposure to drought, no sooner is the plant transferred to its new situation, than it begins immediately to throw out a number of rootlets, which are a great help in establishing it in its changed position, wet or cloudy weather being chosen for this operation. Such trees as holly wiil always be found to answer best when so planted, if they are removed from one neighbouring plot of ground to another; but in the event of their having to be packed up and sent from a long distance, winter $n{ }^{\prime}$ early spring will, perhaps, be found the best time to choose for their transplantation; but in this case the plants should have been disturbed or transplanted in the previous September, so as to cause them to throw out a number of spongioles.

Deep, fertile land, which is elevated above the rise of water, is capable of growing a large variety of hard-wooded trees, each of which have already been described in detail; and there now remains to mention the various low-growing, deciduous trees which play an important part in ornamental plantations.

Lilac (Syringia).-Natural family Olcince. Of the common lilac there are two varieties, the light purple 
colour which confers the name of 'lilac' to materials and substances which resemble in colour the wellknown blossoms of the tree; and white. There are also Persian and Chinese lilac. All are readily propagated by suckers from the roots, and soon strike, and take root quickly, the suckers being produced in abundance; for, although a native of Persia, the lilac is now thoroughly acclimatised in this country.

The common variety appears to have been introduced into Britain either before or during the reign of Henry VIII., for in the inventory taken by order of Cromwell, of the different articles in the gardens of the Palace of Norwich, are enumerated 'six lilac trees which bear no fruit but only a pleasant smell.'

Laburnum (Cytisus).-There are two species of this very ornamental tree most commonly found throughout Britain, which is so highly esteemed as an embellishment along the margins of ornamental plantations, Cytisus Laburnum; the common, or English laburnum, and C. L. Alpinus, the Alpine, or Scotch laburnum.

It is a native of the hilly districts of France, Switzerland, Germany, and Italy, and was introduced into this country at the close of the sixteenth century, seldom growing above twenty feet in height, except when associated with trees of a taller growth which shelter it, and cause it to run upwards, under which conditions it will sometimes attain a height of thirty and forty feet. 
It is very hardy, and will grow rapidly in exposed, cold situations, and on this account is well adapted for shelter to other trees of an ornamental description, but more tender labit. It blossoms in May and June, and as the young plants can be bouglit for a few shillings per thousand, and hares and rabbits prefer the bark and young shoots to those of any other tree, when there is a cliance of these animals doing damage to a plantation, it is customary to plant a number of laburnum plants as food for them, and thus divert their depredations from other more valuable trees. By being frequently transplanted, they may be grown to a large size, and yet be fit for removal, so as to produce an immediate effect.

Cultivation.-The seeds become ripe in the beginning of winter, which are yielded in pods, and are poisonous. These should be sown in light, friable ground, two or three inches apart, and covered with nearly an incl depth of soil. Plants at one year of age are generally a foot high, when they should be removed into nursery lines, two feet apart, the plants standing in the lines about a foot asunder, where they will often make an average advance of three feet during their second year's growth. After the second year standing in nursery lines, they should be removed, or at most after three years; they should then be permanently placed out in the situations they are intended to occupy, or else be again trans- 
exposed, adapted cription, May and sht for a rabbits of any animals mary to food for m other transand yet mediate

e beginand are friable ed with year of ould be e plants where of three ter the ould be should uations trans- planted into wider nursery lines, commensurate with their increased size.

The wood of the laburnum is valuable for all purposes where strength and elasticity are required, such as for pegs, wedges, pulleys, and blocks; articles of turnery; and by cabinet-makers for certain uses; though it is seldom produced above a foot in diameter. Although growing with great rapidity, it soon forms heart-wood of a beautiful description, varying from a brown to a dark green, and occasionally a black colour, which makes a striking contrast to the more recently formed iayers of sap wood. Flutes and other musical instruments are occasionally formed fiom laburnum, but many of the purposes for which it once was used are now supplied by lignum vitce.

There are several varieties, as the purple-flowered and wing-leaved species; purpureus and wolgaricus, which are very handsome, and are frequently engrafted upon stocks of the common labirnum six feet in height. The purple-flowering forms an interesting hybrid between the common laburnum, the purple blossoms of the hybrid being tinged with buff:

The Almond (Amygdalus communis, and A. ama$r u s$ ). - The almond is remarkable for blossoming on its bare branches, and as, in this country, it is chiefly cultivated for the beauty of its blossoms, the common kind, and the double flowering dwarfs, are liked best. 
Poetical allusion has been made to the charming peculiarity of the almond-tree-

The hope, in dreams, of a happier hour,

That alights on misery's brow,

Springs out of the silvery almond flower,

That blooms on a leafless bough.

One of the most beautiful tales of the Greek mythology is founded upon this property of the almond-tree. According to an old tradition mentioned by Servius, Phyllis was changed by the gods into an almond-tree, which is called Phylla by the Greeks. Some days after this metamorphosis, her lover, Demophoon, revisited Thrace, and when he heard of the sad fate of Phyllis, he ran and clasped the tree in his arms, which, although at that time stripped of its leaves, suddenly shot forth and blossomed, as if still sensible of tenderness and love. The absence of Demophoon from the house of Phyllis, according to the legend, suggested to Ovid the beautiful epistle, which is supposed to have been composed by the Thracian Queen about the fourth month after her lover's departure.

Cultivation. - The almond is raised from seed like the peach, for varieties, or for stocks for grafting upon, and by budding on its own, or plum stocks for propagating special varieties, or continuing the same. Although the produce is very inferior to that which is imported, the almond ripens in England, the fruit being chiefly produced upon the young wood of the previous year, and partly on sinall spurs of two or three years 
gr th. Lecording to Haller, bitter almonds are xis on to birds and quadrupeds.

The Large-fruited Almond (var. Macrocarpa).ine llowers of this $r$ iets twice as large as those of the common soil, a waso remain perfect in the tree for a much longer time, the fruit also being much large being perhaps the most beautiful of any of the species. Lindley, in the 'Botanical Register,' describes a specimen in the garden of the Horticultural Society, which he states is increased by budding upon plums and other irupaceous plants.

The Hazel (Cory \& Avellana).-The common hazel comprehends a great number of varieties, amongst which are included filbe $s$ and the great cob nut, and as an ornament is one of the best deciduous trees for underwood, the male catkins making their appearance in September, on the previous year's shoots, but are not fully expanded till the succeeding season, the female flowers appearing about February, and in April are in full blow, being small, and of a beautiful red colour. Few plants retain their leaves longer after being touched by the frost, which changes their foliage into a rich yellow colour, which sometimes causes the tree to remain an ornamental object for some months, till the leaves are finally shed adding richness and seclusion to clumps and narrow belts of trees.

When trained as a standard, it forms a very ornamental tree, often showing a profuse display of catkins, which commonly continue in bloom during 


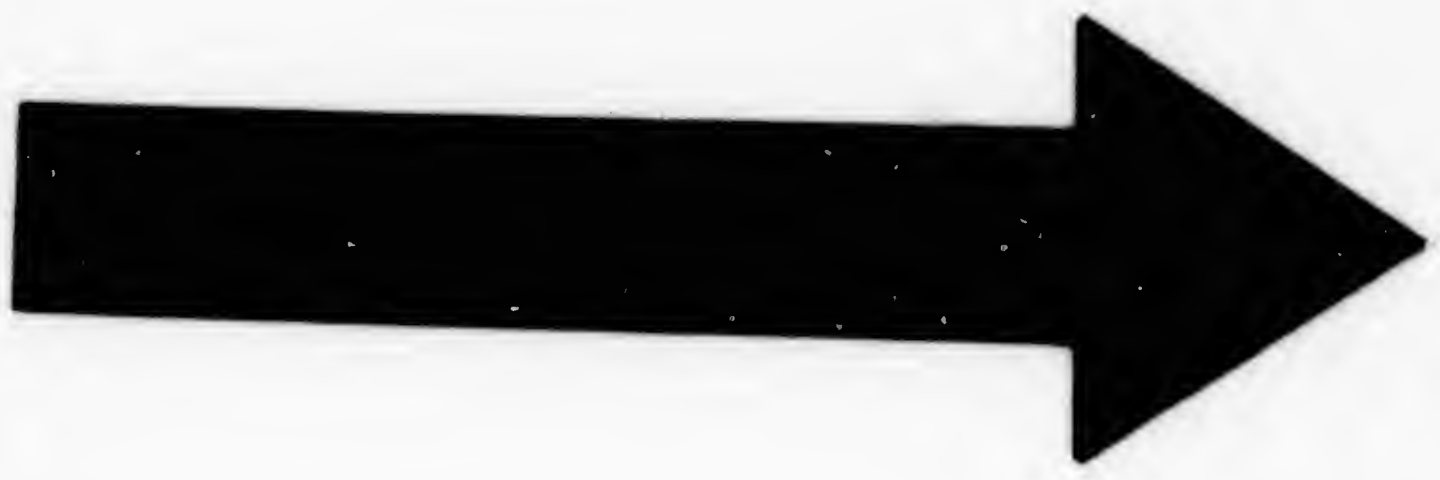




\section{IMAGE EVALUATION \\ TEST TARGET (MT-3)}
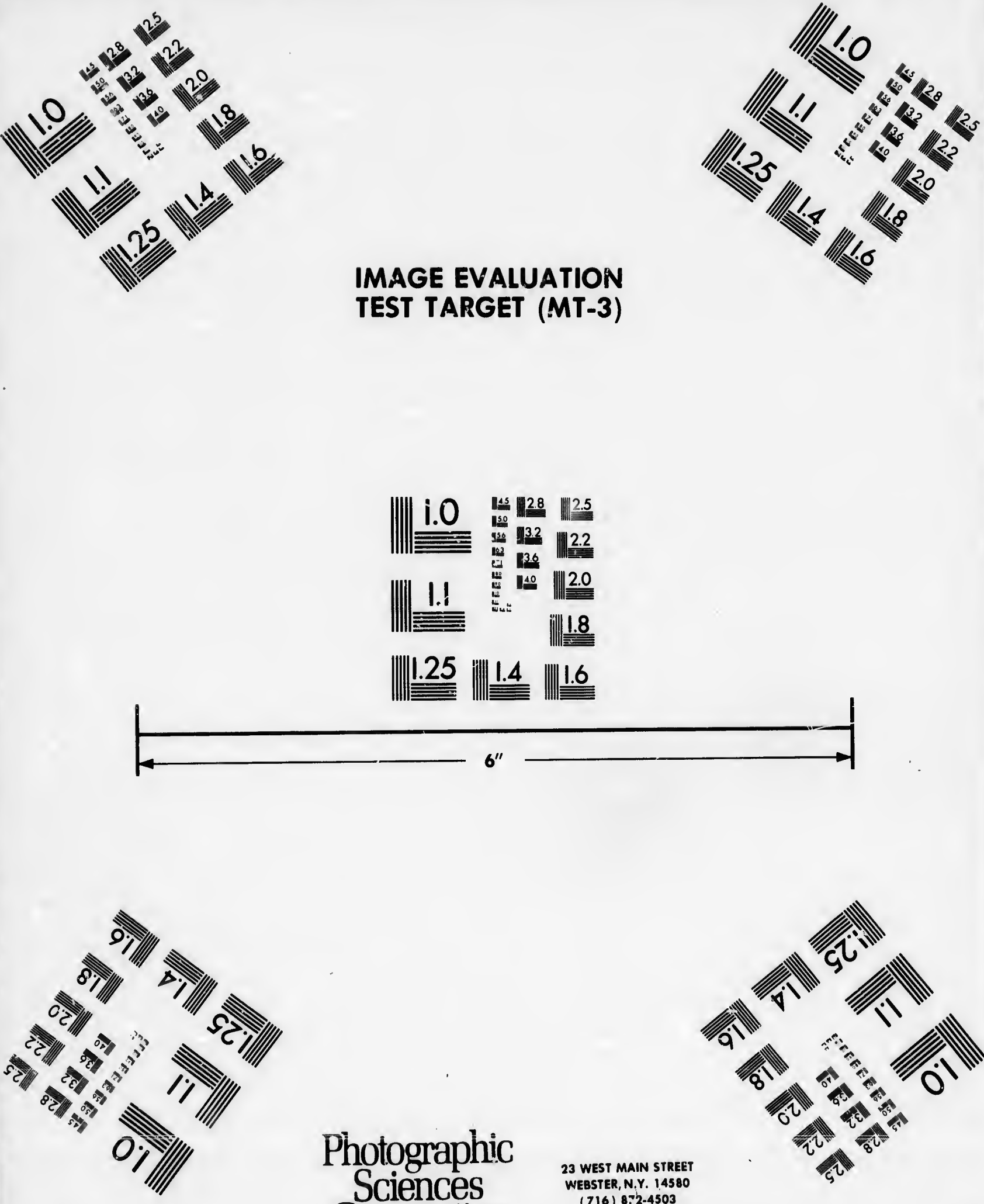

Photographic Sciences Corporation
23 WEST MAIN STREET WEBSTER, N.Y. 14580

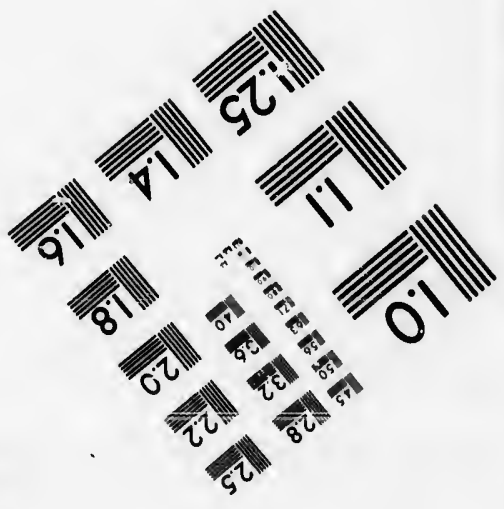



winter and spring, at a season when such objects are most appreciated.

It is said the hazel was originally imported into Italy from Pontus, and known among the Romans by the name of $N u x$ Pontica, eventually changed into that of Nux Avellana, from Avellino, a city of the kingdom of Naples.

The filbert, which is not a distinct species, but merely a variety of the common hazel nut, owes its name to the corruption of the original English name for it, 'full-beard,' descriptive of the large fringed husk, which distinguishes it from the common hazel nut, though Gower, the old English poet, adapts to it the classical legend we have quoted of Phyllis and the almond-tree :

Phillis

Was shape into a nutte-tree,

That all men it might see;

And after Phillis, Philberd

This tree was 'cleped.

There are several kinds of filberts; white, red, frizzled, and cosford being considered the best; the cob nut being an excellent keeper, and growing in a more upright form than the other varieties.

Cultivation. - The hazel is readily propagated by nuts, which ripen at the end of autumn and beginning of winter, according to climate and situation; and as the size and vigour of the seedling plants will be in proportion to the size of the nuts employed for seed, the largest only should be used. The nuts should be sown in winter or early spring, in light, sandy soil, 
the covering being an inch in depth. One bushel of seed is sufficient for a bed of thirty lineal yards four feet in width. The plants kreak through the ground towards the lose of May, and require no further care than being kept clear of weeds during the course of the summer. If the plants come up strongly, they should be removed into nursery lines at a. year oid, but if somewhat weakly, they should be allowed to remain in the seed-bed for two years. The plants should stand in nursery lines a couple of feet asunder, and ten or twelve inches apart in the lines, from whence, after remaining two years, they are removed to their final destinations.

Unprofitable Filbert Plantation made Profitable.An interesting account has been published of a gentleman (the Rev. G. Swayne) who, having a plantation of filbert-trees, which for the first twenty years of their existence produced but very little fruit, at last suspected the cause to arise from a want of male blossoms. He therefore procured a number of catkins from the common hazel, and suspended them over the scarlet blossoms of his filberts, the result being that, the first year of the experiment, he had more filberts than during the twenty preceding ones. In order to make sure that this result was owing to the farina of the male blossonis, he made the experiment of some with and some without such assistance, and found that fruit was produced only upon those trees where the male blossoms had been applied. He communicated his method to a neighbouring farmer's 
wife, who had a row of barren trees, who tried the experiment with the like success, and to evince her gratitude the next season sent the reverend gentleman half-a-dozen pounds of very fine filberts, from four stunted old trees that had not borne any fruit for a great number of years.

Constantinople Hazel (Corylus colurna).-This is the only species of the genus which attains to the size of a timber-tree. The distinguished gardener L'Ecluse is said to have brought the nuts of this tree from Constantinople in 1582, and Linnæus describes a fine tree, growing in the Botanical Garden at Leyden, of this species that had been planted by L'Ecluse. It was first cultivated in England by Ray, in 1666, and has been mostly grown in the neighhourhood of London, having made but little progress in any other part of the kingdom, although it may be readily propagated by nuts, as well as by grafting on the common hazel. It has a white bark and horizontal branches, being quite hardy, and ornamental in appearance, and will attain to the average height of our ordinary timber trees, and seems, somehow, to have been unaccountably overlooked and neglected by English tree-planters. A fine specimen may be seen at Sion House standing upwards of sixty feet in height.

The Hawthorn (Cratogus).-The hawthorn makes the best hedge plant that is to be found in the shape of the sharp-spined or common hawthorn ( $C$. oxycartha), the family being composed of hard.wooded 
ed the ce her tleman m feur $t$ for a

This is to the rdener is tree scribes den at ted by ray, neighrogress it may rafting rk and ornaverage somed and ecimen rds of

makes shape C. oxyvooded

trees, some of the varieties being very ornamental and beautiful when in full bloom; the flowers appearing in the month of May, from which it derives its popular name of 'May,' or ' May blossom.' Although it grows quickly when young, when it attains the height of a tree, it makes wood very slowly, and lives to a great age; the trunk of an old hawthorn having a gnarled, picturesque effect, supporting a broad and full crown of branches that is full, at the proper season, with countless blossoms. The timber is exceedingly hard and durable, the trunks being sometimes split into two or three divisions.

There are several distinct species, as well as many varieties, the scarlet blossomed hawthorn being very handsome, as well as the fruit and white hybrids. The double flowering is one of the most ornamental for shrubberies.

One variety, the selebrated Glastonbury thorn, in favourable situations, flowers as early as Christmas (to which the monks of the dark ages attached a popular legend), and ordinarily in January or February.

Cultivation.-The seeds, or haws, as they are called, should be gathered in Octcber, and they do not vegetate the first year. After being gathered, they require to be laid in a heap to rot, but not in sufficient bulk to allow them to heat, and afterwards to be mixed with about a third of their bulk of sand, and the heap covered over with soil, from three to six inches thick (in the same way that roots are 
covered), and are kept in this way till the following October and November.

The seed should be sown in beds, formed of a rich light hazel loam, though they will grow in almost all soils that are not too retentive; a moderately damp soil agreeing with the young trees better than a dry one; light, gravelly, sandy soils not suiting a seedling crop, as they are apt to get burnt up before they are strong enough to resist the influence of the sun. As soon as the young plants show themselves, a hoe should be drawn along the rows, the drills in seed furrows standing sixteen inches asunder; it being the best method to sow the seed in drills from an inch to an inch and a half deep. When the plants are large enough, they require to be handweeded, and too much care cannot be bestowed in keeping the young plants clear of weeds.

The Mountain Ash (Pyrus aucuparia).-Natural family Rosacece ; icosandria, dipentagynia of Linnæus. This is not only a highly ornamental tree in a plantation, but a very useful one, for although it never attains to a great size, yet it grows very fast aring the first eight or ten years of its life, and is well adapted for giving shelter to slower-growing trees, for although of a deciduous order, the closeness of its branches soon affords shelter. It admits of being planted at a great height, where many other trees would not grow at all, and is the means of giving a valuable amount of shelter in bleak and exposed situations. 
It rises in an upright manner when young, and afterwards forms a well-shaped head, its habit of growth not being influenced by prevailing winds.

In Scotland it may be frequently seen growing in great perfection amidst Highland scenery, when it is locally called the 'rowan tree ' and ' quickbeam.' The stems are covered with a smooth grey bark, the branches being of a purplish hue when young. In the months of May and June it produces highly fragrant white blossoms, which change into a profusion of scarlet berries that become ripe in October, which causes the terminal shoots to bend down with their weight, and glisten amongst the many varied tints of autumn foliage. The buds begin to expand about the beginning of April. When loaded with its clusters of red berries, it has a very rich effect in shrubberies and ornamental plantations, but is not nearly so much applied in England as it deserves to be for this purpose, when it would be found a most useful tree, both as affording shelter and for decorative purposes, the blossoms being produced in large bunches, and composed of fine spreading petals, something like those of the pear-tree, but smaller.

Cultivation.-The berries become ripe in autumn, when they should be collected, and placed in a pit mixed with sand, and be turned over regularly every two or three months, in order to allow them to become regularly decomposed. They should be sown in the ordinary seed-beds early in the second spring after they have been collected, or during the second 
winter, the seeds being spread on the surface, and properly regulated with a rake with such a proportionate distribution as will permit of the plants springing up about two inches apart. When two years old, the young plants should be removed into nursery lines, the rows standing two feet apart, and the plants about six inclies from each other in the rows. When lifted from the seed-bed, however. before being transplanted, their straggling roots should be cut off. The young trees will generally attain a height of four or five feet after standing for two years in the nursery lines, when they will be fit for permanently planting out. If plants of a larger size are required, they should be again transplanted, of course allowing more space for their greater development, and they will then be in a condition to furnish an immediate effect when it is wanted. As a hedgerow tree to give shelter, the mountain ash has no superior, while it also forms excellent coppice.

There are many cultivated varieties, besides the common mountain ash, all of which are highly ornamental in appearance, and valuable for decorative planting, none more so perhaps than the weeping variety, which may be easily propagated by grafting upon stocks of the common sort of service-tree. Some of the varieties are distinguished by having larger leaves than ordinarily, while others have larger fruit. There is also a yellow-berried rariety which is very handsome, and forms an excellent contrast when blended with others. Although these all pro- 
e, and

a pro-

plants

en two

ed into

$\mathrm{rt}$, and

in the

er. be-

should

ttain a

or two

fit for

ser size

ted, of

evelop-

furnish

hedge-

has no

les the

y orna-

orative

reeping

rafting ce-tree.

having

larger

which

ontrast

all pro-

duce seed abundantly, they cannot be relied upon to reproduce the same variety, which in all cases must be done by grafting, and none attain to the size of timber-trees, their chief value consisting in being useful additions to the ornamental belt of trees that may be planted to afford shelter, or to stand in ornamental plantations.

Some fine specimens of the mountain ash are to be seen growing in Inverness-shire, which are forty feet high, the trunks being two feet in diameter, but this is an unusually large size. It attains to an age of several centuries in a cool and moist climate, the timber being strong and elastic, and valued for subsidiary purposes, as for those of the wheelwriglit and turner. It is seldom attacked by disease, and the bark is possessed of a valuable tanning principle.

The Service-tree (Pyrus aria).-The mountain asl is sometimes erroneously called the service-tree, but although classed by botanists in the same genus, it is a different tree, its leaves being entire, light green above and downy underneath, which give to it a bright and lively appearance when its foliage is agitated by the wind.

This also is a hardy tree of great duration, and very closely resembles the mountain ash in almost every particular, except that it very seldom reaches a height of forty feet, its stature being very diversified, and depending for its full development upon the most favourable conditions of soil and climate suited to its habit. It is incigenous to most of the hilly 
districts on the continent of Europe, and grows very freely for the first six or eight years of its life, after which it is apt to incline to a bushy habit, and its upward growth becomes very slow.

Wild Cherry (Cerasus).-This is another genus, comprehending several varieties, which deserves to be much more extensively employed in ornamental planting than at present falls to its lot. The wild cherry, or gean, as it is called in Scotland, can be included amongst our timber-trees, for it may be seen growing in Highland glens at a height of from forty to fifty feet, with a trunk two feet in diameter. The numerous members of this family are indigenous throughout Europe, and differ a good deal in the size and colour of the leaves, the size and quality of their fruit, their rapidity of growth, and ultimate height and bulk, which are necessary considerations in ornamental planting; the Portugal and common laurel belong to the same family.

The common cornel cherry blossoms early, and bears handsome berries, which used to be used as fruit for pies and puddings when the cultivated fruit was not so easily obtainable as at present. The common and blue-berried cornels have red twigs, and make an excellent appearance in an ornamental shrubbery. The wood of the common cornel is very hard, and was spoken of by Virgil as a material in use for weapons of warfare, bona bello cornus. The dwarf species (succica) may also be seen commonly growing in the Highlands of Scotland, and in alpine 
ws very

e, after and its

genus, rves to amental he wild can be nay be f from ameter. igenous in the ality of iltimate erations ommon

ly, and ased às ed fruit

The twigs, amental is very erial in s. The nmonly alpine

districts on the European continent, the berries being considered to possess stomachic properties.

The wild cherry will do very well in almost any kind of soil, so that it is not composed of pure clay, and is dry; a sandy loam iying upon an open subsoil being the most congenial to its growth, succeeding well also upon chalk and rocky positions, when the surface soil may consist only of a thin layer; but although it is very hardy, and will grow at a considerable height, it will only develop itself to the full extent of which it is capable of attaining on low and sheltered land.

In alpine situations it may be seen growing in the clefts of rocks, forming a picturesque object during the whole season, from spring time, when it throws out its pure, rich blossoms, to autumn, when it displays the brilliant tints of its foliage. When grown as a timber-tree, it generally attains its full size in sixty years. Its wood is of a reddish colour, something resembling mahogany, being close-grained and capable of taking a fine polish, and on this account is useful and valuable for cabinet-making purposes. It assumes ¿. fuller and handsomer shade of colour after having been steeped in lime water, and this process as well prevents it from fading when exposed to sunshine, and can be profitably grown as a timber-tree. The stocks are generally used by nurserymen on which to graft all the cultivated kinds of cherries that are valued for the sake of their fruit.

Cultivation.-The ripe fruit is collected when in- 
tended for the purpose of seed, and is mixed with double its quantity of sand, in the same way as previously described with other berries, and they can be sown any time from November till February, in beds of the usual size, the covering of soil being one inch deep.

Some of the plants commonly make their appearance towards the end of spring, but in the case of others, owing to the stones not having decayed so as to perinit of the earth's influence upon the kernel, they lie dormant until the second spring, when the principal crop will be seen. At the end of their first year's growtl, the plants should be lifted from the seed-bed, and trar planted in the usual manner into lines at a distance of six or eight inches apart from one another, the lines being a couple of feet asunder. After standing thus for two years, they will generally be five or six feet high, and be ready for planting out, growing quickly in almost any dry soil.

The perfumed cherry (C. mahaleb), which is commonly seen growing in France and the South of Germany, is quite hardy, and is a very ornamental shrub, and will grow in any kind of soil, however poor, if it be only dry. It reaches a height of about twenty feet, its wood being hard, brown, and capable of taking a high polish, and, when of sufficient size, is on this account valuable, emitting an agreeable fragrance, and being appreciated by cabinet-makers. In France the branches, both in a green and dry state, are liked for fuel on account of their fragrance 
h douviously e sown eds of e inch

ppearcase of l so as kernel, en the ir first in the $r$ into from under. ierally ig out, conlath of mental wever about apable t size, eeable akers. d dry rrance

while burning, and the kernel of the rut is used by perfumers for scenting soap. This species has many seedling varieties, all of whish will stand in exposed situations.

The Virginian Bird Cherry (C. Virginiana), the late flowering or American Bird Cherry (C. scrotina), as well as $C$. pardus (a Greek name given by Theophrastus), the Bird Cherry, the fruit being successively green, red and black, are all very ornamental, according to the season of either flower or fruit; and they possess this recommendation to all lovers of the different objects of animated nature, who delight in seeing singing birds affect their shrubberies and plantations, that they yield an abundant supply of food to these birds, particularly the blackbird and thrush, the former of which may be seen familiarly darting in and out where these trees abound, and will reward their owners by their musical warblings. They also afford good shelter for game, and are well adapted to form underwood.

They may be propagated either from seed or by layers. If seed is used they should be sown when thoroughly ripe a few inches apart, and they will all spring during the course of the first season, after which they should be placed in nursery lines in the usual manner when a year old.

Spindle-tree, or Euonymus.-Natural order Celastracea, belonging to Tetra-Hexandria Monogynia, of the Linnæan system. The common spindle-tree is very hardy and tenacious of life, and will grow fairly 
well in ground of almost any quality, but reaches its greatest height in a deep, rich soil, that is moderately wheltered, with a trunk from a foot to a foot and a half in diameter.

Owing to its numerous white, fibrous roots, which retain within their hold a good portion of soil, it admits of being successfully removed at almost any age or size, and is thus a very useful tree in the hands of the planter. It is propagated either by layers or seed, and is a good tree for planting upon steep declivities, as on account of the nature of its roots it is an excellent medium for retaining the loose soil upon slopes that is otherwise apt to crumble down, and performs a useful office upon the brink of excavations and similar positions.

There are several varieties, the leading species occupying a station half-way between shrubs and trees, varying in height from ten to thirty feet. Their blossons, which appear in the beginning of summer, on account of being the same colour as the leaves, produce little or no effect, but in the autumn the seed-vessels make their anpearance in great numbers, which are of delicate colours, mostly pink or white, that when ripe expand and exhibit seeds of a rich yellow, which, as they hang on the tree for a long time, give it a very attractive appearance; the bestlooking being that with white capsules, which furnishes a stronger contrast to the seeds. The wood is finely grained, hard, and white, and was once used extensively in the manufacture of spindles-hence its 
name-musical instruments, netting needles, the finer articles of turnery, skewers, \&c.

The handsomest tree of the genus is the broadleaved spindle-tree, $E$. latifolia, which is a native of France, Germany and Switzerland; its leaves being broad and shining, and the fruit highly ornamental; this sort seldom rising above a height of twelve or fifteen feet. As well, there are several varieties of dwarf evergreen $\varepsilon$ hrubs, that are very useful in affording shade and seclusion in plantations.

The Elder.-The elder belongs to the genus Sambucus; natural order Caprifoliacece, and to Pentandria Trigynia of the Linnæan system. The black 'Elderberry,' as it is commonly cailed, S. nigra, is generally regarded as a tree of very humble pretensions, and it is a disagreeable tree to many, as its blossoms and foliage, when grown extensively, emit a faint, sickening odour, and is believed to be somewliat unwholesome in hot weather; but it can be made a most useful adjunct, on account of the shelter it is enabled to confer upon other, and less hardy trees; especially in districts which have tc contend with sea exposure, making a capital fence in bleak, maritime situations.

Its medicinal properties have been made use of throughout Europe from the earliest data of medicinal history, occupying a conspicuous place in the works of Theophrastus, and being held in high estimation by Boerhaave, the great physician, the leaves being narcotic, purgative, and acrid; the flowers in 
decoction being diaphoretic. The berries at one tine were extensively used for being fermented into wine, which was formerly often drank in winter time, and given to persons before retiring to bed, who were sufiering from colds. Evelyn mentions a tradition of a family in Spain, who were said to become gradually enervated, and at last died, owing to the fact that their house was situated amongst elder trees. It yields a profusion of creamy, white blossoms in open situations about June, which are succeeded by heavy crops of black berries, and usually attains a height of twenty feet in this country. As well as wine, elderflower water is made, and is considered to b: a cooling and refreshing application for the skin. As before stated, its chief value consists in its being adopted for a screen fence: in bleak exposure, the points of the shoots are cut off, and the tree, in naking fresh efforts of growth, becomes branchy; and gives shelter along its entire height, and will generally advance with a vigour that is seldom equailed by any other plant; in fertile soils often producing shoots five or six feet long in a single summer.

Propagation.-The elder is readily propagated from young shoots, the joints of which are generally from six to ten inches apart. Each cutting or slip should be trimmed so as to have a joint close to its lower extremity, from which the future roots will issue; and another near the top, from whence will proceed the branches of the plant, the cuttings being about a foot long. These should be inserted 
time wine, , and were on of ually that It open leavy eight ldercool-

to about half their length in the ground any time from November till the end of February, when they will be found readily to strike, and make such progress as often to be several feet in height at the end of the first summer. They should be put into lines two feet asunder, and stand in the rows about a foot apart.

The Scarlet-berried Elder (S. racemosa).-This variety is by far the handsomest of the genus, and presents a very ornamental appearance, succeeding best in a somewhat late climate, being a native of the middle and South of Europe, and of the mountains of Siberia. It is equally as hardy as the common species, the young wood yielding racemes of flowers which open with the expanding leaf in spring, the foliage being of a bright colour, anci extremely handsome, its fruit resembling clusters of scarlet grapes in miniature, which attain their brightest hue long before the leaves are shed in autumn, and when in full fruit presents a very beautiful appearance. It is, however, sometimes shy in producing fruit, though it always blossoms with due regularity, a circumstance which may possibly be attributed to the influence of late frosts, as it is known to yield fruit abundantly in the late districts in the Highlands of Scotland. When deprived of its leaves, its chesnut-coloured bark, and the prominent buds in its young shoots, give to it a pleasing appearance when standing amongst other trees.

Another variety, $s . n$. virescens, differs from the 
ordinary black elder in its berries being of a green colour, and its bark whiter, its growth being equally as free and vigorous. As well, there are the 'parsley leaved' and the 'gold and silver blotched' varieties, which are of stunted giowth, but occasionally found useful as ornamental varieties. 



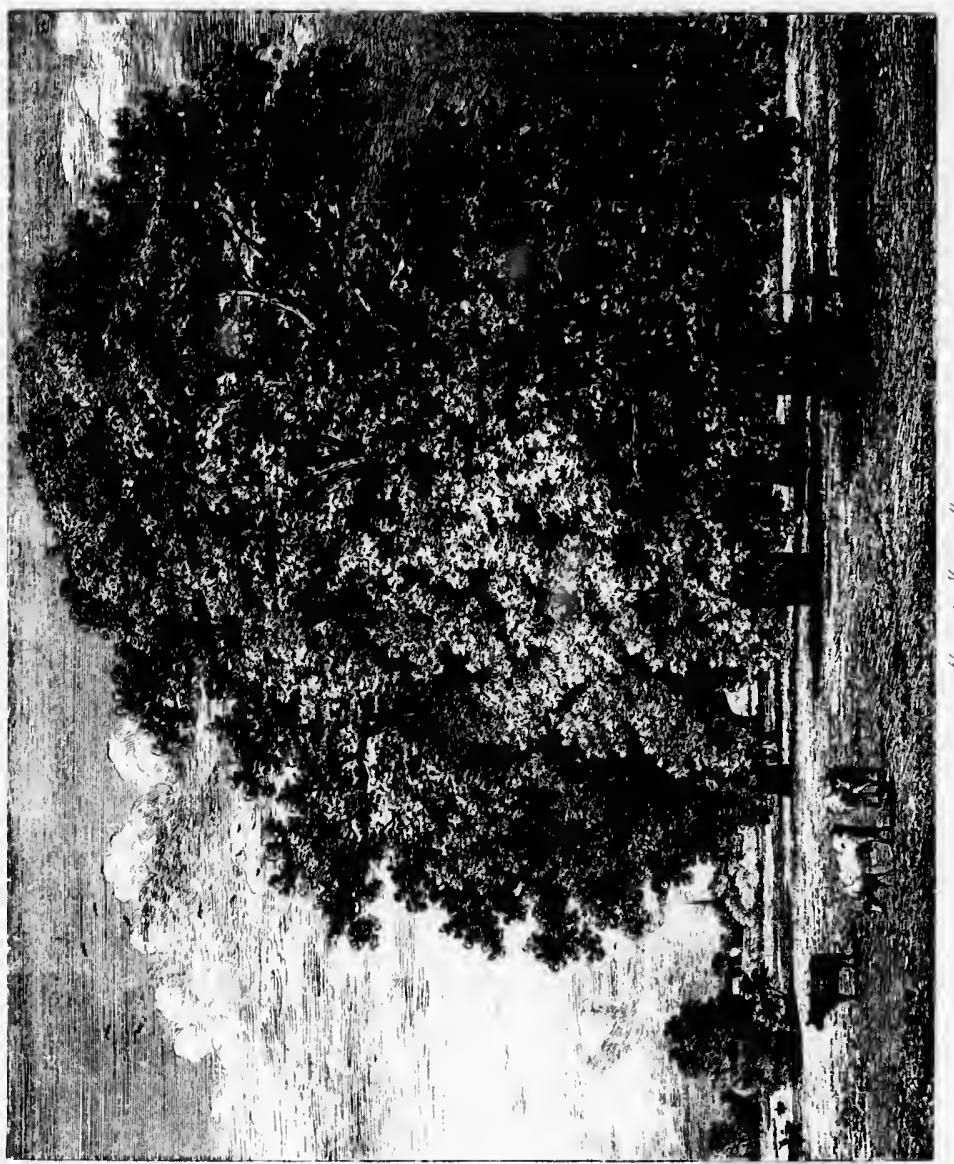




\section{CHAPTER XV.}

ORNAMENTAL PLANTING-(continued).

FVFRGREENS-THE LAUREL-THE LADREL CHERRY, OR COMMON LAURELCULTIVATION-THE PORTUGAL IAUREL CHERRY-PROPAGATION HOLLY-CULTIVATION-BOX-PROPAGATION-PKIVET-ARBOR VITAJUNIPER-THE VIRGINIAN JUNIPER-THE SPANISH JUNIPER-THE COMMON BAVIN.

EveraReENS.-As deciduous trees furnish in summer the most attractive features in ornamental plantations, in the same degree evergreen trees in winter afford a large amount of 'furnishing,' and redeem from bareness the otherwise unclothed aspect a plantation would wear that was made up entirely of leafless boughs; and the beautiful leaves of the glistening holly, with its red berries, and various broad-leaved laurel trees, the yew, box, privet, cedar, \&c., all furnish a mass of dark green foliage very welcome to the eye during the torpor of winter, when the greater part of vegetable creation is in a quiescent condition.

Of the evergreen timber-irees of the coniferous order, which are so well fitted to make a background to an ornamental plantation, we have spoken at length, as well as the evergreen oak, a tree of most useful description, and there remain to be described the lower growing evergreen trees and shrubs.

First anongst these is justly considered the laurel ; 
but, as pointed out, the beautiful evergreens popularly called the common laurel and the Portugal laurel do not belong to the genus Laurus of botanists, but to that of Cerasus, or cherry.

The Laurel (Laurus nobilis).-Natural family Laurino; Enneandria monogynia of Linnæus. The noble laurel, or sweet bay, is the laurus of the Romans, and the daphne of the Greeks, used in their sacrifices, and was consecrated to priests and heroes. It is a native of the South of Europe and North of Africa, but was introduced into Britain several centuries ago, and now occupies a deservedly high place amongst evergreens, forming a dense mass of picturesque foliage, and is abundantly covered with berries, which are dark purple, nearly approaching black in colour.

In some parts of Italy it grows sufficiently high to take rank with trees, yet is so prolific in suckers and low shoots as to cause it to wear the appearance of a gigantic shrub, both the leaves and the berries having a sweet, fragrant odour.

It requires an open, well-drained soil to grow vigorously, so as to enable its young wood to get matured, and be capable of sustaining the effects of frost. It mostly inclines to assume a conical form, and possesses a naturally spreading tendency by producing suckers in shoots from the root, by which it is readily propagated, either by dividing the roots or by layers.

The Laurel Cherry, or Common Laurel (Cerasus 
laurocerasus).-When seen at its best, this is one of the finest evergreens we have, its leaves being large and massive, with a high polish. It is, perhaps, more resorted to as a plant for decorative purposes than almost any other, and on this account is fixed in all kinds of soils, some of which are not suited to its favourable growth and development. In a wet, hard, or retentive soil, it soon becomes affected by the frost, being a native of the West of Asia, and growing wild in woody and sub-alpine regions in the mountains of Persia, and in unsuitable positions it only yields a scanty foliage of sickly liue, and a crop of bare twigs. Affecting shade, it requires a rich, deep, free soil in a sheltered situation, where it becomes highly ornamental underwood, and will often produce shoots from two to three feet in length in the course of a season, and when young is the fastest growing evergreen we have that is adapted for our climate, spreading out in the form of a large bush, rather than assuming the proportions of a timbertree.

It was introduced into Britain in the beginning of the seventeenth century, and is mentioned by Parkinson as growing at Highgate, in his Paradisus, which was published in 1629, and in sheltered situations forms a highly ornamental hedge or screen, the chief use of the plant being for...embellishment, its stems failing to yield a proportionate thickness in relation to their length. The leaves are sometimes used when green, in small quantities, for imparting the flavour of 
bitter almonds to confectionery, but water distilled from the leaves is embued with prussic acid, and on this account becomes poisonous. The principal varieties of the common laurel are the variegated and the narrow-leaved.

Cultivation.-The laurel cherry may be propagated either by seed, cuttings, or layers. The berries become ripe in autumn, when they should be washed to relieve them of their pulp, and immediately sown; but the best plan is to raise plants from cuttings taken in September, and plant in sandy soil partially shaded. These should be a foot long, and of the same season's growth, but having attached to them about an inch of the wood of the previous year's formation, from which the roots will spring that are to sustain the future plant, the cuttings being inserted six inches in the ground. During the following summer these twigs or cuttings will form roots and shoot out to some small extent, and when they begin to close upon one another they should be transplanted into nursery lines at such a distance apart as will allow them to become bushy, and after standing for a year or two they will then be fit to be transplanted out into beltings or shrubberies, or wherever they may be required to stand. If placed along the drives of a wood, they are of a highly decorative appearance, their berries being a favourite food of pheasants, and many a sylvan scene may be vastly improved by the addition of a number of laurels.

The Portugal Laurel Cherry, or Common Porlugal 
stilled

nd on variead the gated ecome elieve at the sen in 1aded. ason's ach of which future in the twigs some n one irsery em to r two beltquired , they erries any a dition rlugal

Laurel.-This variety, although it does not grow so rapidly as the common laurel, is more hardy and luxuriant upon soils of very opposite qualities, and is one of the best evergreens adapted for the climate of England. It is a native of Portugal and Madeira, and was introduced into this country in 1648.

It forms a very compact and ornamental evergreen liedge, as well as assuming the shape of a handsome bush when grown singly, its leaves being so profuse as to show only the recently formed wood; in its native habitat attaining a height of from twenty to thirty feet, and when grown from seed, and pruned early in favourable situations, it will here attain the size of a dwarf tree. The flower-spikes make their appearance early in June, which in due time are succeeded by berries of an oval shape which turn from green to a deep purple colour by the end of autumn.

Propagation.-The Portugal laurel can be raised from cuttings in the same way as described for the common laurel, but when produced from seeds they form the landsomest plants. These need to be collected and dried in a mixture of sand, and kept spread out upon a dry floor until March, when they should be sown. If planted in the autumn, when the seeds become ripe, the young plants will generally make their appearance in March, when they are likely to suffer from the effects of late frosts.

If the young plants come up too thickly, and stand too closely upon the seed-bed, they should be

$$
\triangle 42
$$


transplanted into nursery lines at the end of the first season; but if they have enough room, they may be left standing until they have completed their second year's growth, after which they should be removed and made to stand for two years in lines, allowing sufficient space for each plant to develop its foliage, after which they will be quite ready for planting out.

Holly (ilex).-Natural family rhamni; tetandria, tetragynia, of Linnæus. There are about sixteen species of holly, chiefly distinguished by the varieties of leaves.

The Common Holly (Ilex aquifolium) is a very widely spread plant, being found growing in warm climates as also in cold ones, abounding in most European countries, as well as in many of Asia, and also upon the American Continent; it is found indigenous throughout Britain, being a tree of great longevity that will grow in almost any kind of soil, providing it be not too wet.

Martin first discovered the difference of sexes in the holly, some being hermaphrodite, as well as male and female; and when the top shoot is preserved, the holly will in time grow up to be a large tree, though as a hedge plant it is highly esteemal, cine cially when grown in the vicinity of a gentleman's residence, or as the boundary to a flower-garden, lawn, or pleasure ground. When partially shaded in a ca gial soil, its prickly foliage possesses a dark givelish of the richest description, which 
the

may their $\mathrm{d}$ be lines, velop $y$ for

$d r i a$ xteen ieties

very

warm

most , and indigreat soil,

res in male rved, tree, colseman's trden, haded ises a which

strikingly contrasts with its scarlet berries, and as an ornamental evergreen it possibly has no equal, possessing as it does also the great merit of growing vigorously under the shade ${ }^{-}$and drip of other trees; in this respect being : only equalled by the yew amongst evergreen trees.

The holly forms an almost impenetrable hedge, and for this purpose would doubtless often be more commonly used were it not for its slow growth; and there are some very tall holly hedges in different parts of the country, as the holly walk in the neighbourhood of Frensham, near Farnham, in Surrey, which is mentioned by Bradley as being nearly sixty feet high, and which, if now standing, must of necessity consist of a row of closely-planted trees, though, perhaps, originally a hedge; another lofty hedge having been described at Tynningham, near Dunbar, which was planted by the Earl of Haddington, the author of a treatise on trees before referred to.

Evelyn also had a fine holly hedge at Say's Court, near Deptford, the planting of which was suggested to him by Peter the Great, who took up his abode in Evelyn's house when he worked in the Deptford Dock-yards. Evelyn praises this fence in the following laudatory terms:- Is there under Heaven a more glorious and refreshing object of the kind than an impregnable hedge, of about four hundred feet in length, nine feet high, and five in diameter, which $I$ can show in my new raised gardens at Say's Court (thanks to the Czar of 
Muscovy), at any time of the year glistening with its armed and varnished leaves, the taller standards at orderly distances, blushing with their natural coral.'

- It would doubtless be more corrmonly used as a hedge plant in agricultural districts were it not for two drawbacks. It cannot be safely transplanted when it has attained a considerable size, and its under branches are subject to the attacks of sheep and vermin, which eat them during protracted snow storms that prevail in the north especially, and the plants do not readily send out new shoots to supply these deficiencies, which cause the hedge to become defective and unsightly. It may, however, often be used as an adjunct tc a hawthorn hedge if some holly plants are inserted of the same size as the thorn at the time of planting, placed a few paces apart. Although these in a few years will become almost losi to sight, yet they will eventually spread so freely as to give to the hedge nearly the appearance of an evergreen fence during the winter months, which will greatly add to its appearance, and the degree of shelter it affords.

The closeness of the leaves of the holly causes it to yield a large amount of shelter in proportion to the space it occupies, and while it does not luxuriate at a very high altitude, it is quite hardy in moderately elevated situations, usually attaining a height of from twenty to thirty feet in a wild state, but reaching to a much higher one, as before said, when cultivated in congenial soil. 
th its cls at oral.' as a ot for lanted ad its sheep snow d the upply ecome en be holly rn at $\mathrm{Al}-$ t losit ely as of an which ree of ses it on to uriate rately from ng to ed in

The timber is white and hard, and capable of taking a fine polish, being sometimes dyed black and used as a substitute for ebony, and is employed by the cabinet-maker, as well as for articles of turnery, and in the manufacture of objects known as 'Tunbridge ware.' The bark contains a large amount of viscid matter, and forms birdlime when macerated in water, fermented, and afterwards separated from the fibres.

Cultivation.-The holly is usually propagated by seed, the berries being collected in winter, after they become ripe, when they need to be mixed up with about dcuble their quantity of sand, and turned over every month or six weeks, continual turning tending to decompose the berries more equally than when this is not attended to. In the following winter, during open weather, the seed should be sown in rich, dry soil, of a free open quality, the beds to be of the usual width of four feet, and partially shaded, in such a situation as admits of their having either the evening or mornirg sun upon them. Some of the plants will make their appearance in the following May, but a portion of the seed will remain dormant in the ground until the following spring, it not unfrequently happening that these will form the principal crop, in this case the germination of the seeds occupying a period of sixteen or eighteen months from the time of sowing, so that the surface of the seed-bed during this interval cannot very well be disturbed, and on this account it is necessary not to 
sow the seeds in soil of a clayey nature, which is apt to form a surface crust, and as well become so consolidated that the roots are unable to take hold, and they will die off. The young plants should be removed into nursery lines after two seasons' growth, the lines being a foot asunder, and the plants standing a fegw inches from each other in the jows, and removed again into wider spaces every second or third year, their removal being regulated by the health and vigour of the plants; for if too much checked in their progress by the transplantation, they will lose their leaves, and it will take a couple of years to recover from its effects, but this will not happen if the proper season has been chosen for transplanting them (which is best done in September), and carc has been taken not to expose the roots to the effects of drought. When standing in nursery lines, the spaces between should be well dug, which will have the effect of eausing the roots to throw out numerous tibres, upon the same principle that the horse-hoe is applied to agricultural crops, the digging having an excellent eflect in preparing them for removal, and stimulating their future growth.

Box.-Natural family Euphorbiacea; Monocia tetrandria of Linnaus. The box-tree is a native of all the midcle and southern parts of Europe, attaining a larger size in western Asiatic countries, flourishing in early times, it is said, upon many of the barren hills of England. Boxhill, in Surrey, owes its name to the number of trees which used to dis- 
play their myrtle-shaped leaves of bright green colour in the depth of winter, but they have now all disappeared, leaving only the legacy of the name they were instrumental in conferring.

Two species are only mentioned by botanists, but there are several varieties, the dwarf box (Buxus suffruticos $\alpha$ ) being a distinct species from the cominon box (sempervirens), the former never by any chance attaining to the dimensions of the latter, notwithstanding many persistive endeavours to bring about this result.

When allowed to grow to its full height, it will attain an altitude of twelve to fifteen feet; but in Turkey and Asia Minor it will grow double that leight. It is thoroughly hardy, and will resist the severest cold during winter, but is susceptible to the slightest touch of frost during the season of its growth. On rich land that is partially sliaded, the leaves are of a dense green, and the swelling outline of the tree exhibits a mass of verdure that is unequalled perhaps by any other plant in the dreariest season of the year, when the ground perchance may be covered with snow; but on poor land exposed to the full influence of the suu's rays, its foliage becomes of a faded, or yellowish green, and loses the compactness which distinguishes it when situated in more congenial positions, and although the tree will accommodate itself to various soils, a sandy loam, or deep alluvial soil, are the most favourable for its growth and development. 
It forms a capital hedge, and admits of pruning at any season of the year, and of being clipped into any shape or form that may be desired: the end of June is the best time for cutting box. There are several varieties of gold and silver-edged box, which, it is presumed, owe their effect to having been grown in poorish soils of certain qualities, for these, when freely grown in a shaded situation, lose their distinguishing variegation, and become assimilated to the common variety.

Propagation.-Although plants may be raised from seed, this is seldom or never done, as the cuttings grow freely. The slips should be of the same year's growth with about half an inch of the older wood attached, to form the root of the plant. These should be inserted in lines about a foot or less asuuder; the cuttings being an inch or more from one another in the lines, and should be transplanted after having stood thus for two seasons. Another method is to sink a bushy plant deep into the ground, when the branches readily strike out into roots, and at the end of a year it may be lifted, and the plants divided.

The timber is in demand for those purposes where strength, beauty, and a capability of high polish is required, being used in the manufacture of musical and mathematical instruments; and is remarkably durable when properly seasoned, and is said to be the only European wood that will sink in water; it is used by the printer for wood-cut illustrations, as 
pruning ed into end of ere are which, grown , when distinto the

raised

ne cute same e older These or less from lanted nother round, ts, and plants

where lish is unsical rkably to be ter ; it ons, as

it admits of a finish as sharp and fine as metal; and as it takes the ink much better, is in demand for engraving. Its growth is very slow, yet it well merits cultivation on account of its embellishing qualifications, seldom in this country producing timber until it is one hundred years old; the largest amount of timber that was ever felled at one time in this country probably being when the box-timber was cut down at Boxhill in 1815, which was sold for upwards of $10,000 l$.

The Dwarf Box (Buxus sempervirens suffruticosa), which is extensively used as edging for garden walks, is easily propagated by dividing the plants, which in course of time grow very thick and bunchy.

The Minorca Box (Buxus Balearica) has leaves which are three or four times the size of the common box, and the tree attains to large dimensions in its native country, but it is less hardy, and the timber is very inferior.

Privet (Ligustrum).-Natural order Oleina ; Diandria monogynia of Linnæus. When found growing wild in woods and hedges, privet is usually deciduous ; but under cultivation it becomes an evergreen, in which form it is commonly recognised as a familiar hedge-plant in this country. It is extremely hardy, and will thrive in almost any soil and situation, and is especially valuable as a suburban plant for the decoration of gardens in somewhat confined quarters, as it will stand the smoke of cities, and is indifferent to the drip of other trees, although to produce gcod 


\section{ENGLISH TREES AND TREE-PLANTING.}

flowers it requires an open situation, a crowded position not being the natural one of any plant. The colour of the berries varies from purple or black to white or yellow, and they remain on the branches during winter, but are seldom eaten by birds unless the season happens to be unusually severe, and they can procure nothing else.

Like a good many other plants that have been for a long period under a course of cultivation, several varieties have become established which differ from one another in the shape of their leaves, flowers, and fruit; the most common of the latter assuming the form of elegant purple clusters. In some instances the leaves grow by threes, and are enlarged at the base, and also are variegated.

It stands pruning well, and may be cut into any form at pleasure, and is a very useful plant for forming a screen fence, or for relieving the stems of taller trees from a bare appearance which they will otherwise present in a shrubbery or ornamental plantation, and is a most useful plant of a subsidiary order, being of a very ductile nature.

Arbor Vitce (Thuja occidentalis). - The arbor vitæ is a native of Canada, but it has been long established in this country, and although familiar to most in the form of an evergreen shrub, it is occasionally met with of sufficiently large size for its timber to be used by the turner and cabinet-maker, the wood being considered more durable than almost any other. 
cowded

The lack to anches unless d they

been vation, differ owers, uming ne inlarged

to any formtaller otheration, order, vita lished in the met to be wood any

In America it develops itself with the greatest freedom when the roots have access to abundance of water, and accordingly is found to grow most freely in swamps and marshes. In dry situations it becomes stunted, and never attains to any size or great degree of perfection.

It is said that the first tree of this species which was sent to Europe was planted in the reign of Francis I., in the Botanic Garden at Fontainebleau. When burnt, the wood emits an agreeable odour, and is said to have been used by the ancients at their sacrifices, and hence the name from the Greek word thuo, to sacrifice. Although a handsome plant, which may often be used to great advantage in blending with other trees of the shrubbery, it is not of a nature that causes it to be resorted to so freely as many others.

Juniper.-This genus comprehends a number of evergreen shrubs and low trees that are natives of all quarters of the globe, embracing fully twenty species, which again run into almost an endless number of varieties.

The Common Juniper (Juniperus communis) is met with in all the countries of Europe, alike on fertile and barren soils, on hills or in valleys, upor open sandy plains, as well as in close, moist woods, on the sides of hills growing with a tall trunk, but on the tops of mountains or in bogs becoming only a tufted shrub.

In England it is chiefly met with upon open 
downs which rest upon a sandy or chalky subsoil; and in the forest of Cawdor Castle, in Scotland, some trees are to be seen which measure upwards of twenty feet in height, with trunks from a foot and a half to two feet in circumference. Growing in ground of such very opposite qualities, its character changes a good deal according to circumstances, and while, when situated in a dry, deep, loamy soil, it gains the height of a dwarf tree, in fine gravel, and in wet situations, it only becomes a low-spreading shrub.

Its name is said to be derived from the fact that the berries remain on the plant for two years, and are found at various stages of maturity: hence the name of the shrub from junior, younger, and pario, to produce-i.e. while some of the fruit is ripe, a younger crop is still in course of being produced. The principal use of the berries is for flavouring gin, but they form a powerful diuretic, and are used a good deal in medicine, and they require to remain on the tree two years before they assume the black colour which indicates their maturity, having a peculiar aromatic odour, with a somewhat bittersweet pungent taste. In distillation with water they produce a volatile terebinthinate oil of a greenish colour, the flavour and diuretic properties of Hollands being due to the presence of this oil, oil of jumiper being used as a diuretic in medicine. The oil from juniper is also much appreciated in the preparation of varnish, while the spray is used as fuel where it abounds, for smoking hams, so as to give them a 
absoil ; , some rds of and $\mathrm{a}$ round langes while, is the in wet ab.

that $\mathrm{s}$, and e the rio, to pe, a uced. gin, sed a main black ig a itterthey enish ands iiper from ation re it m a

recherché flavour. When grown in a loose, open soil the roots yield long, tough fibres, which in the Highlands of Scotland are split up, and woven into creels and hampers that are used in carrying to and fro agricultural produce, noted for their durability, and their capability of resisting the influence of alternate drought and moisture.

The Virginian Juniper (J. Virginiana).-This is the tallest and hardiest tree of the genus, being often met with in its native country sixty feet high with a trunk two feet in diameter. This is the red American cedar, and was introduced into Britain in the early part of the seventeenth century, and it will attain similar dimensions in this country.

It grows best in a rich, deep soil, and where the land is very moist it will at times assume the form of a broad-spreading tree, but generally takes that of a beautifully formed conical evergreen, and as it is very hardy, no better tree could be planted in a shrubbery for the purpose of giving shelter to more tender plants. When reared from seed, its progress will be as rapid as that of the Scotch pine, and it is apt to produce a great many seedling varieties, which differ in the shape and size of their foliage and habit of growth, as well as in the structure of their branches, many of which will be found to turn out very handsome.

The seeds slould be sown in beds of the usual form, and the seedling plants transplanted into nursery lines when they are one year old, or at most 
two years, and afterwards again transplanted every second year, until they are finally established in the positions they are destined ultimately to occupy.

The quality of the timber varies a good deal in the different varieties, being mostly of a brown colour, with a fine grain that is capable of taking a ligh polish, and on this account is a useful wood for the purpose of the cabinet-maker, and is often used in articles of turnery.

The Spanish Juniper (J. thurifera), or Incensebearing Juniper.-This is one of the handsomest species we have growing in this country, and it is now established in general cultivation, forming a beautiful low, evergreen tree, seldom exceeding a height of thirty feet, and having a pyramidal head. Its large black berries, when they become ripe, form a strong contrast to its vivid green foliage, and few trees can be found that will present a more ornamental appearance in a shrubbery or upon a lawn.

The Common Savin (J. Sabina).--In some of the Greek islands this variety is found growing as a tree, though it only attains a height of a few feet in this country, being indigenous in France, Spain, and Italy, in the form of a low-spreading evergreen shrub. It is one of the least ornamental of the genus, but is sometimes considered interesting as a variety, the plant when disturbed or bruised giving out a strong, disagreeable odour, the leaves and tops having a bitter, hot taste, of an acrimonious order, which is 
every in the y.

leal in colour, a high or the ised in

ncensesomest $\mathrm{d}$ it is aing a ling a head. , form , and more pon a of the a tree, $n$ this Italy, b. It but is $y$, the trong, ing a ich is

due to the presence of an essential oil that is obtained in considerable quantity by distillation with water, both the latter and alcohol extracting its active principles. Savin is known as a powerful stimulant, both internally as well as externally when applied to the skin, and is used in the practice of medicine. It is said to produce abortion if eaten by domesticated animals during pregnancy.

There are several varieties, all of which readily strike root, and can be propagated by fixing the prostrate branches into the ground.

The Bermudas Cedar (J. Burmudiana).-This is a species of West Indian juniper, and although it was introduced into this country upwards of two hundred years ago, its cultivation has not become general like that of the Virginian juniper-a much more modern importation-being too tender for the climate of Britain, except in the most favoured situations. In its native country its dimensions assume those of a tall tree, while here it seldom exceeds the stature of a shrub. The timber of the Bermudas cedar is esteemed for its fragrance, being a preventive of moth and other insects, and therefore very appropriate for clothes-presses or drawers, and is employed by the cabinet-maker for inlaying, and is used in the manufacture of black lead pencils.

The common juniper forms capital underwood, and is well adapted as shelter for game, its cover being the favourite resort of the woodcock. 


\section{CHAP'TER XVI.}

OSIER BEDS.

LAYING DOWN AN OBIER PLANTATION-THE LONDON OLAT-VARIETIFS OF SOIL-DURATION OF OSIER PLANTATIONS-MFNDING OSIFR PLANTATIONS-CUTTINA OSLERS-TIIF PREPARATION OF RODB FOR WRITF BASKETS-COUCIING-VARIETIES OF OSIFRB-TILF SPANIARD-THF NEW KIND-THE GELSTFR-THE GREEN-LEAVED OSIER-TIE BROWNARD, OR SILVER OSIER-THF FRENCH-THE IIOLLANDER-THE BITTER OKNARD-THF GTONE OSIER.

Osier Beds.-The osier is a native of most parts of Europe, and is found springing up spontaneously by the margin of rivers and other watery places, the term being usually applied to the basket-making willows, but more especially to the salix viminalis, or common osier, and its varieties. The common osier is, however, soft and brittle, and has been superseded by better kinds, more adapted for the purposes of the basket-maker, many of which would be undistinguishable to ordinary observers, but are vell known and appreciated by those accustomed to use and handle them.

A good deal of confusion thus exists with respect to the names and varieties of the salix, being indifferently called willows by some, and technically termed rods by basket-makers in the neighbourhood of London, where they are grown to a large extent 
on the banks of the Thames, the 'Great Metropolis' being a very large customer for baskets of all kinds ; and in common parlance the word osier is often used for any kind of willow-tree, of which there are many varieties, some attaining the size of timber (which the dwarf willows never do), as the arborescent willow, that grows to a large size by the side of rivers, of which we tre reminded in the Psalms, when the Children of Israel moumed their captivity-.'By the rivers of Babylon, there we sat down, vea. we wept when we remembered Zion, we hanged our harps upon the willows in the midst thereof;' and the. weeping willow we have before described, which is a native of the Levant, but thrives uncommonly wel! in England, in those situations that are not tco coid for it.

Basket-making is a very ancient business in England, and as the Romans taught the Britons a good many things, it has been supposed that, in turn, the latter taught the art to the former, from the mention of a basket, in Martial, that was brought to Rome by painted Britons, which appeared to excite appreciation in the capital of the world; and the ancient Britons occasionally made their boats of basket-work of willow, which they afterwards covered with the skins of animals, and so constructed a craft remarkable for its lightness and buoyancy. The Romans, however, regularly used the willow in the form of binders, or withes, as they are termed in England, to tie up the vines to their poles. 
The shoots of the yellow willow (Salix vitellina) are more slender than those of the osier, and being very tough, are especially well adapted for the purpose of the basket-maker; and there are other varieties which have thrown the common osier a good deal out of general cultivation, some of them possessing considerable merit, the best variety of the salix viminalis, a common osier, being known by various names, as Snake Osier, Brindled Osier, Blotched Osier, and Speckled Osier, which are indeed all the same thing; but the appearance of osiers varies very much according to the ground in which they are grown, being sonetimes of a green, and at others of a yellowish-brown colour. The velvet-topped and apple-tree osier follow next in order of appreciation, while the long-skin closely resembles the ordinary osier in appearance, but is of smaller growth, firmer and touglier, its wood being also lieavier.

The varieties grown on the banks of the Thames are mostly of a red colour, but it has been observed that the action of light has a great effect upon the colour of osiers, in some seasons being of a yellowislbrowl, which may be regarded as their ordinary colour, and in others of a dull green ; in fine sunny clear seasons they become of a bright red colour; in cloudy ones, they turn a dull mahosany shade. Those called rods and willows by the London basketmakers comprise several varieties, which have got to be commonly cultivated, and comprise the kinds called the Skit Willow, the Godstone, or Hornrod, of 
which there are a couple of varieties; the Wire Hornrod, which takes its name from, and is esteemed for, its toughness; and the Water Hornrod, which is of very inferior quality, as is also the Yellow, or Dutch Willow, which not only grows rough and twiggyan objectionable habit for the basket-maker,-but is of so soft a substance as not to bear soaking so well as the other kinds. We will afterwards speak of other varieties in detail; but in laying down an osier bed, it is necessary to choose the most profitable and useful varieties that can be obtained, as some kinds are comparatively worthless for manufacturing purposes, though all are extremely valuable in giving consistency to oanks and embankments that are in danger of being washed away.

Laying down an Osier Plantation.-The best situation for an osier bed is 1pon land that is subject to tidal overflow, and therefore not fitted for the growth of any other crop, and it shonld first be trenched about fifteen or sixteen inclies (leep. Sets are then cut of the kind it is desired to propagate, the sets being about fifteen inches long, which are planted at various distances, according to the quality of the soil. Where the soil is light and the supply of moisture imperfect, and likely to be interrupted, and the shoots of the plant are likely in consequence to be fewer and shorter, it is usual to place them in rows about a foot and a half apart, standing about fifteen inches from each other in the rows, the sets being inserted in the ground ahout half their length 
in such soils and situations, the lighter kinds that are used for making small baskets answering best. If they were not planted so thickly as this, instead of drawing one another up straight and slender, they would be apt to grow branchy and crooked, and thick and clubby next the stools.

In stronger and richer soils, the rows should stand two feet apart, and the plants a foot and a half asunder in the rows, for the strong plants will attain a height of ten or a dozen, or even thirteen feet; and if the same plan of closer planting were followed with these, there would not be sufficient space for all the shoots to ripen which the stool would throw out; and while a few of the leading ones would draw one another up very tall, they would obscure the action of the light upon the others, and being unable to ripen their wood, it would become soft and pithy, and unfit for the purpose for which it was designed, if grown for sale for basket-making.

The sets are cut from the lower part of the shoots, and, in the case of the larger sorts of osiers, are grenerally about the thickness of the little finger, and they strike more strongly than sets taken from the top end, which, although they will grow readily enough, will always throw out comparatively small shoots.

Osier's grow to the greatest perfection on strong, rich and loamy soils, and they succeed very well on marshy land which consists of a nixture of peat. On the banks of the Thames in Berkshire, where the 
that are best. If nstead of der, they ked, and

s should ad a half ints will thirteen ing were sufficient he stool leading all, they pon the wood, it tlie pursale for

e shoots, re geneand they the top enough, oots.

strong, well on of peat. ere the soil is light, and consists of a good portion of sand, the French, Goldstone, and a variety which is locally known by the sobriquet of Black Jack, do very well, the most luxuriant growths being upon soils that are situated on the banks of rivers of an alluvial nature, that are flooded by every tide-this being the case on the banks of the Severn, which is celebrated for its unusually high tides.

Some of the largest and best osiers are grown on the banks of the Thames and Kennet, in Berkshire and Oxfordshire, none perhaps exceeding those in size and bulk of crop that are grown near London, between Chelsea and Riclimond, on the banks of the Thames. The soil is naturally rich in that area, and the lands are generally overflowed at high water, and the sediment which is left behind is equivalent to constant manuring, as from the traffic on the river about these parts the water is kept in a continuous turbid condition, and a top dressing of rich mud is left behind upon each occasion.

The London Clay.-The different qualities of the soil on the banks of the Thames are made clearly apparent by the varied growth of the osier beds, willows and rods of excellent quality being grown as high up the river as Kingston and Ditton; but above, at Staines, Shepperton, Chertsey, Windsor, and Maidenhead, the soil changes, and the crops, though of considerable bulk, are far inferior in quality to those grown lower down, and can only be used for making the coarser kinds of hampers that are used 
for packing-baskets; but where the subsoil of blue London clay crops up, when the roots of the osiers come in contact with it, they invariably die off.

Osiers, to be most profitably grown, require a strong staple, with a compact subsoil that will retain the moisture which is necessary to the plants during the period of their growth, but they will not succeed upon strong clayey land that in summer time becomes hard, dry, and full of crocks, through which the moisture evaporates.

Varieties of Soil.-Certain kinds of osiers will, however, grow and do very well upou light lands, if the subsoil is moist with springs, as is often the case, for which such kinds as the Spaniard, the French, and the New Kind are best adapted; but the crop will always be found to be smaller, shorter, and less bulky than when grown in strong loam, the best situations for osier beds being in low situations, when the water drained from the ligher lands keeps them constantly supplied with moisture, although they may be grown on elevations where the land is springy, as well as on slopes, yet not so successfully.

Duration of Osier Plantations.-Upon land best suited for their growth and development, osier beds will last for a very long time, with a little occasional mending where the standing crop has become defective. Seventy or eighty years is no uncommon period for a good osier bed to last; but where they are grown upon the lighter soils, or in those situations that are only imperfectly supplied with moisture, 
of blue

e osiers ff.

quire a 11 retain during succeed ime bewhich

ars will, lands, if he case, French, he crop nd less he best s, when s them h they pringy,

ad best

$r$ beds asional defecmmon e they rations isture, their duration will only be for fifteen or twenty years, and to cause them to yield the most profit they will then need to be thrown up and laid down afresh. But by the banks of rivers, in those situations where there is an abundant supply of moisture, their cluration is considerably greater.

Mending Osier Plantations.-A few of the stools in an osier plantation die off every year, and in some seasons this happens to a considerable extent, but they can be mended very easily, the chief casualties occurring when the winters, having been very mild, are succeeded by severe weather in March and April. In these unfavourable seasons it is by no means uncommon for two-thirds of the crop to die off, and stout shoots are found to make no effort to push out in the spring, this kind of weather being very fatal to osier plants.

When mending has to be performed, the largest and smoothest rods are chosen of the kind required, and their butt ends are cut in a slanting direction, and they are inserted into the ground to the depth of nine inches or so, by the side of the dead stools, the rod being inserted whole, and not cut into the form of a set, as in the case of making a fresh plantation. The object of doing this is to prevent their being smothered by the older stools, which would happen if they were cut; but being left of their full height, they enjoy the benefit of light and sun for a great portion of the summer, before the others can grow high enough to interfere with them, but after 
two year's they are cut back to the lieight of the other stools.

Cutting Osiers.-Osiers for basket-making are cut every year, and a clear profit of $20 l$. per acre is estimated to be obtained from good osier beds. The proper time for cutting is hrtween the tall of the leaf and the rising of the sap' '. 'ng. If tle crop is cut late in the spring, it tendi wo weaken its future production; and although osiers are sometimes cut before and after the period named, it is well to avoid this in general practice. Those wlo make a business of growing osiers for basket-making sort them, after they are cut, according to their different sorts and sizes, separating the long and thick from the short and small ones, and the rough from the smooth osiers. The stock that is intended for the manufacture of brown baskets is then dried and stacked, care being taken in drying them not to lay them too closely together, or they will heat, like a hay crop that has been insufficiently made, and they will then be useless for the purpose of basket-making, as the leated parts decay and become rotten, and the same consequence will arise if, after the osiers have been dried and stacked, rain penetrates the stack, which it is therefore highly necessary to exclude.

The Preparation of Rods for White Baskets.Osiers that are intended to be made use of in the manufacture of white baskets need to have the bark stripped from off them. In order to effect this, after they have been properly sorted, they are placed in 
are cut acre is s. The of the he crop s future mes cut o avoid ousiness m, after i'ts and e short smooth anufactacked, em too ty crop ill then as the e same e been which

kets.-in the e bark , after ced in wide and shallow trenches in an upright position, with their butt-ends resting in water, which should not be less than four inches deep. A rivulet with a gravelly bottom, where such is to be found, answers the same purpose equally well, and they are placed in an upright position, and secured there by posts and rails.

When the sap rises in the spring, they will begin to bud aud blossonn, much in the same way as if planted in the ground, and will be in fill leaf about the beginning, or the second week in May, at the same time throwing out spangioles or rootlets, about an inch in length. When these results take place, the sap is then sufficiently raised to admit of the bark being removed, and this is effected by drawing the rod briskly through an instrument called a break, which, pressing the bark, causes it to burst and separate from the rod.

Couching.-When, lowever, the weather is unseasonably cold, which will sometimes happen to be the case, a difficulty is experienced in stripping off the bark thoroughly, a thin underlayer remaining attached to the rod, which is caused by the cold checking the flow of sap, so that the bark cannot be taken cleanly away. To remedy this, recourse is had to a method called couching, which is occasionally obliged to be resorted to, for otherwise the rods will present a brown and discoloured appearance, which will very much reduce their commercial value. This process consists of laying down the rods in a sheltered 
position that is well watered, and covering them over thickly with straw, or any other covering that will thoroughly exclude the external air. In a fortnight's time they will shoot in the same way that barley does under the process of malting, and will spire, as it is technically called, all over, when the bark will be found to separate freely. After this has been done, they must be placed in an upright position against some railings, where the air can pass thoroughly through them, and be carefully dried; after which they must be stacked away in some building where they will be perfectly dry, and to which no moisture can have access. If they are stored away in a clamp conclition, or any water get to them afterwards, they will become clamaged.

Varieties of Osiers.-The leading varieties of osiers not before fully mentioned may be briefly enumerated as follows:-

The Spaniard, or Spaniard Rod.-There are several varieties of this kind, some of a very excellent and useful quality, while other's are of a very inferior description. The Black-budeled is a useful variety, that is made use of for finishing the rims and handles, and also the bottoms of certain kinds of baskets, while the Gray Spaniard is used for coarse brown packing-baskets, and is considered a tolerably good variety for such purposes, as well as the Brown Spaniarl; but the Horse Spaniard is of very inferior quality.

The New Kind (Salix forbyana). - The new kind 
of them ng that 1 a for'tay that nd will ien the er this upright an pass dried; n some and to ey are ter get ties of briefly

c are cellent nferior ariety, indles, askets, brown good Brown ferior kind

somewhat resembles the Spaniard in its characteristic of strength, being equally strong: winile it is more pliable and easier to work.

The Gelster.-The Gelster is also very similar to the Spaniard in its main qualities, and is of more tapering form, but the butt-end yrows very thick.

The Green-leaved Osier.-The Green-leaved Osier, or Ornard (Salix rubra), is considered an excellent and tough variety when the bark is left on, and is . thought the best kind to make use of in the manufacture of carboy baskets used by drysalters.

The Brown Rod, Brownard, or Silver Osier (Salix: IIoffmanniana).-This is a somewhat short species of osier, but of a firm quality, and good for certain purposes, as for eel weels, or baskets, and is silvery on the under side of the leaf.

The French, French Rod, or Real French.-This variety is a good deal grown for small fancy basketwork, and in Franee is muel used by wine-coopers, for twigs for binding on the numerous wooden hoops that are plaeed round French wine easks. It is grown to a somewhat large extent in France, and derives its name from the faet of being almost universally used in that country.

The Hollander.-The Hollander, which takes its name from having been brought originally from the Dutch coast, where it may be seen growing in large quantities, very much resembles the new kind in quality, though it differs from it in appearance.

The Bitter Ornard (Salix purpurea).-This variety 
assumes a slender form, and is tough, and well adapted, like all the other ornards, to grow in wet land that is commonly covered with water. The Blunt-leaved Ornard (Salix Lambertiana) is an inferior variety, as well as the Rose Ornard (Salix Helix), and the Bastard French: these are all of a poor kind, and fit only for making the commonest hampers and fish baskets, being brittle, which causes them to break in the working, the snapped ends projecting outwards and inwards in an unsatisfactory manner.

The Slone Osier.-The stone osier is another variety well adapted for fine basket-making, and is a good deal grown along the banks of the Kennet, where it is considered to be a very good soil.

In France, where the niceties of osier-growing are more attended to than in England, on account of a greater demand for the small fancy baskets that are sold in large quantities, they have a system in some parts of the country, where very fine, slender osier shoots are required, of cutting rods up into short pieces, and then laying them in drills a short distance apart from each other, the result being that the roots strike from several points of the buried surface, producing a iumber of slender shoots, an upright shoot springing from almost every eye. In England, bulk and quantity are more generally ained at, and a coarser trade in basket-making is followed to a greater extent.

Osier growing is well worthy the attention of those who have land adjoining streams that is either 
periodically flooded, or naturally of too wet a description to produce ordiuary agricultural crops. Many such waste tracts are to be seen in different parts of the country, where nothing will grow save sub-aquatic plants that are of little or no value, that might be profitably appropriated to the production of osiers.

nother and is Kennet,

rowing ccount ts that em in lender p into short g that ouried ts, an

e. In ainied lowed

of either 


\section{CHA PTER XVII.}

\section{IJEDGE-ROW TIMBER.}

EXCESSIVF QUANTITIES OF HEDGF-ROW TIMBER-MOST SUITABIL: TREFS FOR HEDGE-ROWS-ORNAMENTAI, HEDGE-ROWS-MANAGEMENT OF HEDGE-ROW TIMHER.

Hedge-row Timber.-Although the quantity of timber grown along the divisions of fields by the road sides, and to mark the boundaries of estates, at first sight may not appear so very great, except in a few counties, as Warwickshire, that are remarkable for the great number of trees dotted all over the face of the country, it is supposed to be greater in its entirety than the whole bulk which is produced in close woods and forests. The importance of hedge-row timber is, therefore, much greater than is commonly supposed; and although in some districts these may be overcrowded, yet in many districts the want of trees rauses the landscape io appear bare and uninteresting, and in many parts of North Britain the crops often suffer from that want of shelter which trees could be made the means of affording.

Both extremes are, however, to be avoided, for while on the one hand excess of shelter exhausts the 
soil, and inpoverishes the crops, and often exercises an unwholesome effect during humid autumn seasons; on the other, in exposed situations, from an absence of shelter, not only pasture land, but crops of every kind are retarded, more particularly in the spring of the season, when it is very necessary that young crops should have a good start. $\Lambda$ s the season further advances the unchecked winds damage the stems of the growing cereal plants during summer, while in autumn the damage they cause in shedding the grain is often very considerable; and where high winds prevail in some parts of North Britain that are destitute of shelter, the gales which frequently occur towards the end of June or beginning of July not only frequently disturb and injure the plants, but are sometimes known to actually drift them away; this happening most frequently when rough weather comes after turnips lave been singled out, which are more particularly liable to suffer from high winds.

In windy situations, plants shauld be employed that are stout in proportion to their height; some trees which have been already described being better calculated to give shelter than others; and where single trees are not sufficient, a screen should be formed of shelter-giving varieties.

Excessive Quantities of Hedge-row Timber.-It is in these situations that ledge-row timber becomes most valuable, and it is, as well, a great improver of the natural scenery of a district where trees are somewhat scarce; but, without doubt, there are many localities

$$
\text { c c }
$$


that suffer from too large an amount of hedge-row timber, where they exclude the daylight and harbour vermin. On this account many farmers object to trees, and would gladly see them all felled, although it would materially injure the beauty of the rural scenery of a district; and no doubt an excessive quantity of hedge-row timber has an injurious effect very often, not only in the exclusion of daylight, but does positive injury to crops where the wrong kind is made use of, as the ash, which is ruinous to graincrops within the influence of its roots ; and yet it is a tree that may be commonly seen adopted for this purpose.

Mast suitable Trees for Hedge-row Timber.-One of the best trees for a hedge-row is the English Elm (U. campestris), and it is the one most generally preferred in England. It admits of being placed in the position it is intended to occupy when it is compara. tively of a large size as a plant, owing to its bushy roots, which allow of its removal beyond the size of most young trees, which is a very important matter, as hedge trees are apt to be injured by vermin. Its figure is tall and erect, the spread of its branches not being very great, and by proper management some valuable timber may be produced. The elm makes a useful pollard, and will allow of being frequently lopped, furnishing a good deal of timber in a comparatively short space of time. There is, however, one objection to it, which is found in the number of suckers it throws up from the root, 
dge-row harbour bject to lthough he rural xcessive us effect ght, but ng kind o grainet it is a for this

r.-One ish Elm illy prein the ompara.s bushy size of matter, in. Its ranches gement he elm being timber here is, in the e root,

though this ceases to be an objection if young trees are wanted.

The various kinds of oak all make good hedgerow trees, for although not standing so erect as the English elm (which is less spreading in its habit than $U$. montana), the roots of the oak strike deeply down into the earth, having a strong tap root, and in consequence is not injur.ous to the crops in its vicinity, being less dependent upon the surface soil for its support than many other trees. Also, it breaks out into leaf later than most other trees, and thus does not intercept the influence of the sun's rays upon the young growing crops at a time when warmth and light are of the most service to them.

Hedge-row trees very often fail when planted, and this commonly arises from the fact, that the young trees have been allowed to grow to a comparatively large size without repeated removals into nursery lines, a necessity which has been repeatedly brought before the reader's notice in the present work, by which the roots become far better adapted for transplantation, and establishing themselves in a new situation. At other times they are not sufficiently protected from the damage that is likely to ensue from cattle; while the exposure, and nature of the ground, is not sufficiently taken into consideration very often.

In situations that are too windy and exposed for many of the broad-leaved varieties of trees, that might otherwise be chosen, the mountain-ash, service-

$$
\text { c o } 2
$$


tree, sycamore, Scotcl elm, beech, and the hoarypoplar (Populus canescens), are the most likely kinds to succeed; the mountain-ash, service-tree, and sycamore being the most unyielding to the influence of rough winds, keeping well balanced heads and a proper form; while others would get dwarfed, and bent in the prevailing direction of the wind, the three kinds named growing erect even at great elevations, and preserving shapely heads.

When evergreen trees are desired, the holly, though slow growing, makes a good hedge-row tree, as well as the evergreen oak, the tallest being Turner's evergreen, while the Fulham oak, a sub-evergreen, is also a valuable kind for this purpose.

For the formation of rows of trees, not intended to be interspersed amongst general agricultural crops, but as objects of ornament or shade, for avenues of approach, or to mark the boundaries of any tract near a residence, where embowering shade and seclusion are required, the horse-chesnut is one of the most suitable trees, its beautiful blossoms in the spring presenting a rich appearance at that particular season, while at all others its full foliage and handsome shape causes it to be a very useful tree for the purpose.

The lime, with its large umbrageous head, coupled with its sweetly smelling blossoms, has perhaps no superior. The plane is also a very suitable tree, as well as the sycamore, Scotch elm, Spanish chesnut, and beech; which are all of a spreading habit of 
hoary-

ly kinds nd sycauence of and a fed, and he three evations,

e holly, ow tree, Turner's ergreen, ntended al crops, nues of 1y tract d secluof the in the rticular d handfor the coupled aaps no tree, as chesnut, abit of growth, which causes them to be very appropriate for this purpose; and for the formation of a stately avenue, or an approach to a mansion, the tall English elm is a very imposing object, and is frequently made use of on this account.

Ornamental Hedge-row Trees.-When ornament is desired in hedge-rows, there are various flowering plants that may be had recourse to, the laburnum and scarlet horse-chesnut being extremely well adapted for this purpose. An ordinary hawthorn hedge may be considerably beautified and improved by selecting some of the strongest and most vigorous stems that are making their way upwards, and grafting upon them the handsomest varieties that are most attractive when in flower, as the scarlet and double red, the most ornamental kinds for blossom and habit of growth being Cratogus macracantha, C. glandulosa, C. prunifolia, C. punctata, $C$. coccinea, and $C$. aronia. Holly hedges may be so trained as to allow the strongest stems at regular intervals to run upwards, when in time they will assume the dimensions of moderate sized timber, and the top be trained in any shape that may be considered desirable, when grown in a somewhat round form, and covered with scarlet berries, presenting a very handsome and attractive appearance. Ivy adds greatly to the appearance of trees when ornamentation is desired, but this is very often shunned under the supposition that it impedes the growth of the tree. But ivy does no harm in climb- 
ing over trees, when it creeps gradually upwards, though if perchance it completely twines round a branch, it would undoubtedly act as a ligature, and prevent the descent of sap, and so in time destroy the branch above it; but as ivy is a creeping plant, and not a twining one, this circumstance will but very rarely occur.

Management of Hedge-row Trees.-In planting trees in hedges, their roots should not be sunk beneath the surface below their natural depth, the object being so to place the upper fibres as that they may obtain the advantage of every shower that falls. For the first few years after the young plant has been piaced in its position, the vigour of its growth will be much promoted if the surface of the ground is kept loosened, and free from the herbage, -specially matted grass, and other natural vegetation, to an extent which will correspond with the range of its roots.

The method of pruning hedge-row trees is another point of great importance. Many persons are in the habit of clearing the trunk of all the lateral branches to a considerable height, and allow the top ones to take just what form they please. The result of this course of treatment is, that the tree has a tendency to spread, and form a large head; and in some kincls, as the oak, these will ramify to such aii extent as to produce limbs of nearly equal magnitude to the trunk, and in the case of all trees it will have the effect of retarding the height and increasing the 
upwards, round a ure, and troy the ant, and ut very planting ee sunk pth, the at they at falls. ant has growth ground pecially , to an of its

another e in the ranches ones to of this ndency kincls, it as to to the ive the ng the breadth of the tree, which is just the opposite result, perhaps, it may have been intended to produce. When the production of useful timber in the hedgerow is sought for, the treatment should be very different, attention being mostly required to be directed to the top, or leading shoot, and the. branches nearest to it, with the view of continuing the upward growth of the trunk, and preventing it from getting cleft and divided into forks. To carry this out effectually, the leading shoot needs to be preserved, and the competing ones shortened to about half their length, which bear any proportionate size to the main one, the same principle being carried out with all the side branches that grow too luxuriantly, which will check their progress more or less in proportion to the distance they are cut from their extremities; which will cause the principal flow of sap to be directed to the main shoot, or stem, which will be greatly increased in height in consequence, and the remaining portions of the branches can be removed in future years at a period when the bole will have attained such dimensions as not to cause their removal close to the trunk to blemish the timber as they continue of small diameter. If large boughs are removed at any time, and the timber is made coarse with large knots, its value will be decreased at least one-third.

September is the best time for lopping trees, as the wounds are immediately healed by the descending sap; and if hodge-row trees are carefully treated, 
their timber will be found invariably hard and good, and as well clean grown. When in the forest, the thick planting which is natural to trees in such a situation supersedes the necessity of much pruning; but when they stand singly, trees have a tendency to ramify, and if the pruning is done early and skilfully, there will be no necessity for the removal of any very large branches, by which the value of the timber becomes greatly deteriorated, and this part of their management is very important.

In many very exposed situations, the broad-leaved varieties of timber-trees, save those of an exceptionally hardy nature, cannot be got to grow singly in hedge-rows, without the shelter of plantations. For this purpose belts of coniferous trees are well adapted, and these may afterwards be felled, when single lines of trees have been successfully raised through the instrumentality of the protection they have afforded. The hedge-row trees when fully established will not only continue the shelter from field to field, and so equalise the climate throughout the year, but combine utility with greatly enhanced beauty of the rural scenery, which is naturally a point of much consideration with most landowners desirous of the improvement of their estates.

Climate has everything to do with the kind of trees that are planted, but it is impossible to compute the extent to which even climate may be modnied by judicious planting of the forerunners of all our broadleaved varieties, the principal of which are the Scotch 
THE INFLUENCE OF CLIMATE ON TREES. 393

pine, larch, and spruce-fir ; by the use of these, the area of our broad-leaved trees may be much extended, both as regards latitude and elevation. The larch is seldom found growing as a hedge-row tree in highly cultivated districts where there is a good climate, yet, nevertheless, it might be much oftener made use of, and is a very suitable tree for the purpose, and would offer a pleasing variety to those more universally resorted to. It grows quickly, is less subject to disease in isolated positions than when standing in masses; no other tree is less injurious to grain crops, while its deciduous habit enriches the soil by the annual falling of its leaves: planted singly, however, in rough situatioris, it is apt to become unsightly, and bent by prevailing winds. 


\section{4}

ENGLISI TREES AND TREE-PLANTING.

\section{CHAPTER .XVIII.}

COPSE-WOOD.

USES OF COPPICE-WOOD-VARIETIES OF COPSE-WOOD-COPSN-WOOD OR UNDERWOOD-MANAGEMENT: OF COPPICE-MAKING CHARCOAL.

CoPSE-WOOD, or coppice, is cultivated very often for widely different reasons, and often with distinct objects in view, and consists of trees which, unlike the coniferous order, spring freely from the root when they are cui down periodically, before they attain the size of timber trees, or, as in the case of the oak, after the timber has been felled.

There are many situations in rural scenery when copse-wood possesses greater powers of embellishment than standing timber even, softening the outline, and producing an agreeable vista in the forest that is often highly desirable, in such positions where taller trees would cramp and exclude a distant prospect. By the margins of lakes and rivers, on islands, in various odd corners and bare situations, a clump of coppice becomes a capital cover and finish; in narrow belts it forms an excellent screen fence; and in a variety of ways is often a very important section of tree-planting, especially when a profitable return is aimed at. 
Uses of Coppice-wood.-The product of copsewood is applied to a great many uses. Oak and beech are chiefly raised on account of their bark, and are allowed to attain a larger size for this reason than most other trees, being lopped over at various times, which is regulated by the soil and climate at different periods, ranging between fifteen and fiveand-twenty years, the felling of the trees for the sake of their bark being executed at the end of spring, the bark being harvested in early summer.

There are many situations in which the oak, as well as other trees (but more especially the oak, on account of the long tap root which it sends down to a great depth in the soil), makes no perceptible progress after thirty years, which is commonly due to a subsoil that is unsuitable to its growth or habit, and in such positions to grow coppice pays better than timber, whatever the want of progress may arise from, which will sometimes be caused from the effects of a bad climate, the oak becoming dwarfed and stunted when growing at a great elevation, or in too cold situations. The root-ends of oak coppice are used by the wheelwright for making wheel spokes, and after the bark is stripped off, the wood is sold for charcoal and other purposes, the ordinary product of oak coppice at the age of twenty-five years being generally estimated at from $30 l$. to $35 l$. per acre, after all previous and current expenses have been paid, or somewhere about twenty-five shillings per acre annually, after interest, \&c., has been de- 
ducted. The rule observed in the management of coppice is, that whenever at any period of its $\mathrm{g}_{1}, \mathrm{w}$ th the yearly increase does not amount to the interest of the 'money, as a low rent for the land, to cut it down; sometimes even when quite young, oak coppice may be seen without any vigorous shoots at the extremity of the branches, the spray terminating in a feeble and curled manner, this being a sign that its vigorous progress has become arrested, when it should be lopped over, a common result being that in many situations a far greater bulik of timber as well as value is ensured when coppice has been cut two or three times in fifty years than if the trees had been allowed to stand for the same number of years.

Beech is less valuable than oak as coppice, but the same stunted habit of growth will distinguish it in certain situations, and dead twigs be seen towards the top occasionally, when it should be cut down, ard both it and the oak after this has been done will produce shoots from their stools equally as vigorous as upon land that is capable of producing better native timber. The common uses to which other coppice-wood is put are for poles of various kinds, handles to implements, lioops, hurdles, charcoal, firewood, \&c.

Varieties of Copse-wood.-Besides oak and beech, which are chiefly valuable for the sake of their bark, there are other kinds more specially fitted for particular soils and situations. Thus in a damp soil in 
nent of $\mathrm{g}_{1}$,wth interest cut it g, oak shoots termieing a rested, result bulk of ce has if the umber ce, but uish it wards down, done lly as lucing other kinds, arcoal,

beech, bark, paroil in low-lying situations the different varieties of the willow may be profitably cultivated. Besides the dwarf willows for basket making, of which we have spoken at length under the heading of osier beds, which are cut down yearly, there are other varieties more particularly fitted for coppice, which are generally cut every five, six, or seven years, the produce being mostly applied and used for poles, hurdles, scythe and rake handles, and for making crates, \&c. ; the goat sallows ( $S$. caprea) being an excellent variety of willow for these purposes, in soil best suited to its growth, making shoots eiglit to ten feet in length in the course of a single season, and in bad soil even producing a profitable crop where nothing else could be grown that would pay nearly as well. Although willows like moisture, stagnant water is not beneficial to them, and a greater yield is obtained from land that is drained and relieved of stagnant water to within a few feet of the surface, even in the case of willow coppice.

Hazel makes good copse-wood, liking a dry soil, and although it does not attain a very large size it yields an early return, which in some districts is very paying, being sometimes cut every second or third year, and for some purposes, as that of hoops for barrels, it is considered of equal quality to oak, and when intended for this application is generally allowed to stand for five years; but hazel, as a rule, is not as much grown in the form of coppice as of underwood. 
The Spanish Chesnut is a good variety of coppicewood, springing freely after being lopped over, and making good hop-poles, \&c., making the best stakes, or for any purpose where it comes into actual contact with the soil, the amount of leaves which it sheds being of especial value, in sandy districts, in forming a top soil.

Ash coppice is useful for many agricultural purposes, as hop-poles, hurdles, handles of implements, as well as for many uses where strength and elasticity are needed. Besides the kinds named, the elm, maple and alder will all spring freely from stools, but are not so generally cultivated for coppice, the revenue from copse-wood being a good deal influenced by local demand, as, for instance, the hazel is much in demand in the vicinity of potteries, for making crates in which earthenware is packed, being fit to be lopped for this purpose every second or third year.

Copse-wood as Underwood.-Copse-wood when grown beneath trees takes the form of underwood, the hazel being a good deal used for this purpose, especially on the borders of plantations, or woods, where it also acts as a screen fence, but when grown beneath the shade of other trees, the quality of coppice is likely to be deteriorated, and its yield lessened, unless in exposed situations where shelter may
be desirable.

When coppice is interspersed with timber trees, the oak is the best for it to accompany or grow with, as it comes into leaf late in the season and does not 
give that deep shade which some trees would cause; as well as for the reason stated before, on account of its tap root providing sustenance for the tree at a great depth downwards, and not taking the resources of the surface soil.

Although the larch cannot be strictly spoken of as a coppice-tree, inasmuch as it does not spring from the roots when lopped over, yet it is a very appropriate one to grow interspersed with timber, filling up the vacant places in the same way that copsewood generally stands, for it rises with an upright figure, and soon becomes valuable, and as its roots spread near the surface of the soil other trees generally do very well in its vicinity, and in the case of the oak especially, when associated with it, all the resources of the soil are called into requisition, the top part being appropriated by the larch and the lower by the oak.

Management of Coppice.-In cutting down copsewood it has to be borne in mind that, as a future crop will be expected at a certain period, the stools require to be cut clean and smooth, so that water may not find a lodgement, and so close to the ground that the shoots which are to form the subsequent crop may spring close to the roots and not at some distance above them, in which case they are likely to be injured and blown off by the wind, a bill-hook being the best instrument for cutting ordinary coppice; but in the case of oak coppice, which has been allowed to attain considerable size, it is the common practice to 
saw all the stems which exceed four inches in diameter, and cut the smaller ones with a bill-hook, or an adze, and by cutting them upwards the stools are left unblemished.

After oak timber has been felled with a view of allowing the stools to form subsequent coppice, the top of each stool should be cut upwards in a convex form, so as not to hold water, taking care to avoid injury to the bark that remains, in the operation, which will protect the stool from any parasitic fungoid growth that might otherwise infect it.

As the stools of large trees are frequently more difficult and reluctant to yield a young growth than smaller ones, it is often necessary to clear away the surface herbage around them, which oauses them to spring forth much more freely. The second year after the timber has been taken away, the shoots should all be carefully inspected, and the supernumerary ones removed out of the way, the number left depending upon the judgment of the forester, according to the space occupied by the stool, and the purpose for which the springing coppice is destined. In the instance of oak coppice that may be intended to stand for fifteen or twenty years, it is generally usual to allow more stools to remain than it is ultimately intended there should be, and afterwards thin the smallest ones out, and bark them when about eight or ten years of age. Oak forms the only exception in this respect, all other copse-wood being cleared off at once, any other method being calculated to do 
in di-hook, stools

iew of ce, the convex avoid ration, c fun-

more than le surspring er the all be les r'eending to the se for $n$ the ed to usual nately n the eight eption ed off to do

harm to the growing crop of other species. Oak and bircl: are felled at the time we have specified, on account of its being most suitable for bark; but all other sorts of coppice-wood should be cut down between the middle of autumn and the middle of spring.

In forming coppice of oak, chesnut, or willow, they should be planted at distances of five or six feet apart from one another, with larch interspersed, to act as nurses. In the case of oak plantations, larch or Scotch pine are generally first planted on the site, and the young oak trees inserted after the firs have got to be a certain height, a few years afterwards, and these are cut down after having performed their allotted task as nurses. Stout plants of larch, as they grow quickly, do well when planted at the same time as other copse-wood, on account of the shelter which they afford. Hazel, and the trees which are only needed to acquire a comparatively small size, should be planted at distances of four or five feet.

The inroads of cattle and sheep are very destructive to young copse-wood, and these should be carefully guarded against; but in the case of some plantations, as of larch, when the trees have acquired a certain size, and cannot very easily be injured, a good bite of tender grass is often to be had, and, under proper supervision, they may be made usetiul and available for young stock, though the practice of turning them into plantations is not 
generally looked upon with any degree of favour, and its use demands proper care and attention.

Where copse-wood is cultivated to any considerable extent, it is advantageous so to manage matters as to cause a portion to come on in perpetual rotation, which may be cleared and prit to profitable use yearly. By this means not only will an annual return be made in the shape of income, but the hands employed upon the cultivation, and who are constantly kept at work in thinning, cutting, barking, \&c., will do their work in a more thorough manner from constant practice, which will canse the plantations to be managed in a superior form, and succeed better from the details being more effectually performed than when done by hands that are only occasionally employed, especially where charcoal is constantly made.

Making Charcoal.-Charcoal in some districts finds a ready sale, and is always more or less a marketable commodity, and is formed by the refuse, or waste parts of coppice-wood that cannot be profitably used or sold, after being cut in suitable lengths, being placed in a heap, and covered over with a slight covering of earth, and then set fire to. Where wood is covered up, so that it cannot feel the full action of the atmosphere, it burns with a smothered flame, and the volatile parts are driven of by the heat, so that there remains behind the residuum in the exact form of the original woody substance, even in its distinct layers, the woody form alone resisting the action of 
favour, onsidertters as otation, ble use unal ree liands re conarking, manner plantasucceed ly pernly ocis conts finds ketable $r$ waste ly used being slight e wood ction of ne, and so that ct form distinct tion of

the heat. All parts of the plant, whether solid or fluid, make charcoal; and from a number of experiments that have been made upon different plants and their various parts, it is shown that the green parts contain a greater proportion of charcoal than the rest, the proportion diminishing in autumn, when the green parts begin to be deprived of their gilutinous and extractive juice.

The quantity of charcoal, however, differs in various plants, as well as in different parts of the same plant: the proportion in the plants examined by Proust of wood charred being represented as follows :-

$$
\begin{aligned}
& \text { Black ash . . . . . . . . } 0 \cdot 25 \\
& \text { Guiacum . . . . . . . } \quad . \quad+0.24 \\
& \text { Pine . . . . . . . . . . } 0.20 \\
& \text { Green oak } \quad . \quad . \quad . \quad . \quad . \quad . \quad . \quad . \quad .020 \\
& \text { Heart of oak . . . . . . . . . . } 0.19
\end{aligned}
$$

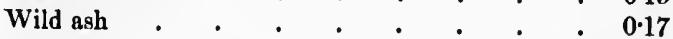

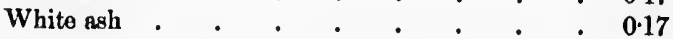

Chemists regard charcoal as consisting of a triple compound, the ingredients being carbon, hydrogen, and oxygen. 


\title{
CHAPTER XIX .
}

\author{
SEASIDE PLANTING.
}

PLANTATIONS ON THE COABT OF NORFOLK-PINEASTER FORESTS AT THE GULF OF GABCONY-MANAGEMENT-VARIETIFS OF TREES BEST BUITED For sEaside pLaNTING.

Seaside Planting.-Seaside planting in England is comparatively a new thing, very little having been done till towards the close of the first half of the present century, when some very $\mathbf{n}$ teworthy instances arrested the attention of planters, and created a good deal of interest upon the subject, trees having been successfully established upon soil of apparently the poorest description in the close neighbourhood of the sea, which used to be regarded as totally unfit for vegetation.

The influence of the sea spray is felt for a considerable distance over many tracts of land in close proximity to the sea, and that which has been done of late years proves to demonstration that these otherwise barren districts can be made fertile, by establishing upon them forest trees. These trees in such situations are not only valuable on their own account in the production of timber, but they afford a shelter which was never enjoyed before by adjoining lands, the fertility of which is, in consequence, considerably increased. 
Plantations on the Coast of Norfolk.-In 1840, and the three following years, some plantations were formed on the estate of Sir Thomas Fowell Buxton, on the cliffs on the northern extremity of the county of Norfolk, close to the Yarmouth Roads, the surface of the soil being poor for the most part, and the subsoil consisting of a hard, ferruginous gravel, ranging from 200 to 300 feet above the level of the sea, embracing a space of about 114 acres.

Several kinds of trees were used in the formation of these plantations, the goat willow, and the pineaster especially, having been found to succeed well, both these kinds standing sea-exposure. An account of the formation of these plantations was furnished to the Highland Agricultural Society by the late $\mathrm{Mr}$. Grigor, of Norwich, to whom the Society awarded their gold medal.

The success of these plantations was attributed to several circumstances, and details of manage ient: the land, in the first place, having been carefully trenched to the depth of a foot and a half; next to the erection of screens, six feet in height, composed of furze, brushwood, and similar materials; to making use of plants of the best description two or three years of age that had been transplanted a year in nursery lines before their permanent removal, by which a bushiness of root was encouraged which enabled the young plants to establish themselves, being closely inserted at the time of planting, standing about two and a half to three feet apart in the 
first instance; and to carefully hoeing the land for two years after it had been planted, during which period remunerative root crops were obtained from amongst the young plants, the whole expense being -trenching, $6 l$. per acre ; fencing, plants, and planting, rather more than $4 l$. per acre; making the total cost upwards of $10 l$. per acre, exclusive of the hoeing, the cost of which did not reach to more than a fourth part of the value of the crops of parsnips, carrots, and cther roots that were raised; the result being achieved in the face of many discouragements, and forebodings of total failure on the part of neighbouring planters, who would not believe the plan could ever be made to succeed, which is now evidenced by their close approach to the sides of the German Ocean, what was formerly an unproductive tract of land now being clothed with thriving plantations, from which large quantities of thinnings have been obtained.

The same was also suiccessfully done in 1840-42 by Mr. Grant, of Glenmorriston and Moy, N.B., who formed several hundred acres of thriving plantations; and, as well, plantations of considerable extent were formed on the sands of Culbin, which occupy several thousand acres of the north-west corner of the county of Moray, N.B., and are composed of small hills of sand, varying from twenty to a hundred feet in height, the surface of which is continually shifting through the influence of the wind.

In the case of Mr. Grant's plantations, the land is 
PINEASTER FORESTS IN THE GULF OF GASCONY. 407.

id for

elevated from twelve to thirty feet above high-water mark, and is one mile inland, the plantations consisting of native Scotch pine and larch, so that little or no fencing was required, the leading feature in this instance being that the plantation was bounded by a vast expanse of undulating sand, with a surface given up entirely to abandonment, marked only by the wavy ripples caused by the wind, and upon which nothing ever arose in the furm of vegetation, except a clump or two of bent crass here and there.

The plants established themselves successfully, except in a few instances where the drifting sand mastered them a short time after their insertion; and upon examining some of the roots six years after they had been planted, it was found they had extended themselves to an almost incredible distance, some of the roots being upwards of twenty feet in length, to which numerous fibres were attached, developed by the fine particles of sand, which, penetrating in so many directions, caused the trees not to suffer from drought; while the hold or grip they had on the land, after they had taken root for a few years, enabled them successfully to resist the influence of the wind, which offers a very lively illustration of the advantages to be derived fron planting upon a loose soil with a clean surface, whether the land may happen to be either poor or rich.

Pineaster Forests at the Gulf of Gascony.-But although seaside planting in Great Britain is but of comparatively modern date, a very remarkable 
example was furnished in France by M. Bremontier of the Administration of Forests, in 1789, who planted pineaster trees at the Gulf of Gascony, upon downs perpetually shifted by the wind, which, before he commenced his operations, consisted only of a monotonous succession of sandy hillocks, entirely destitute of vegetation. A commission was appointed by the French Government in 1811, to report upon the result of this undertaking, which reported that 12,500 . acres of downs had been covered with thriving plantations by means of sowing pineaster seeds, by a method which was as remarkable for its simplicity as its success.

The plan consisted of sowing two pounds of pineaster seed in conjunction with four to five pounds of broom seed per acre, and immediately the sowing was done, covering it with branches of pine or other trees, beginning at the side next the sea, or from the quarter from whence the wind most commonly prevailed; the sowing being done in narrow zones, in a direction at right angles to that of the wind, the first sown zone being shielded by a line of hurdles, this zone protecting the second, the second the third, and the third the fourth, and so on continuously. After the sowing was done, the ground was immediately thatched with branches overlopped to protect the seed, with the liurdle fence that had been placed to intercept the course of the sand wherever seed was sown; the surface of the sand being immediately thatched. Sea-weed, reeds, and 
METHOD OF PLANTINA ON THE SEA-SHORE. 409

rushes were also used, as well as branches with the leaves on for thatching, and were found to answer equally as well.

The broom made its appearance first, the plants having reached a height of six inches in two months or less, attaining three or four times that altitude before the close of the first season. The pineaster plants only reached a height of three or four inches during the course of the first season, and it takes seven or eight years for them to overtop the broom, which in those downs will sometimes reach twelve or fifteen feet, during which time they will perform the duty of nurses to the young pineaster trees. At the age of ten or twelve years, the pines will get the mastery of, and extirpate the furze, at which age they will be thinned out, and the thinnings used for the purpose of thatching the downs not yet recovered.

Such is the method that was followed in the formation of these extensive plantations, which, together with others in the sands of Bordeaux, which lie between that city and Bayonne, are the chief support of a great proportion of the inhabitants, who prepare resin and tar from these pineaster forests.

Management.-'The best method of management that can be pursued in those places where it is desirable to form a seaside plantation where the land is mucl exposed to the influence of the sea, is to raise a screen fence, composed either of turf, brushwood, hurdles, or of any materials that can be most conveniently 
obtained. The higher this sureen fence can be raised, the more efrrablity it will answer its intended purpose, and cxteud its influence over a wider surface. The most difficult site near the seaside upon which to establish a plantation is that which is exposed to the effects of a rough sea, and is only a few feet above hign-water mark, sloping gradually upwards from the sea, without any undulating formation which is able to confer a certain amount of shelter. Lines of screen-fences in these situations should be erected successively every twenty, forty, fifty, or up to one hundred yards apart, according to the degree of exposure to which the land is subject. When the area is sufficiently elevated above the sea level, it will not feel the influence of the sea spray to such a damaging extent, and numerous fences will be unnecessary; but in very exposed situations, a cover of brushwood spread over the seeds, in addition to the screen fences, is advisable to ensure success.

Light sandy soil in close contiguity to the sea is sometimes found covered witr a matted coating of the coarser kinds of native $\mathrm{g}$. asses, the roots of which have a very adverse influence upon the growth of young trees, and act as a great impediment to their first establishment; and any soil that produces herbage of this objectionable nature is difficult to cover with healthy plantations, and this difficulty is only to be overcome by trenching, which is best done a few months before the young plants are in- 
an be tended $r$ surupon ich is only a dually g forint of ations forty, rding subabove le sea erous posed the ble to ea is ating ts of owth it to uces $t$ to culty best in-

serted, so as to allow sufficient time for the buried herbage to get decomposed.

Varieties of Trees best suited for Seaside Planting.- The pineaster, as shown in the instance of the pineaster forests in the Gulf of Gascony, endures the influence of the sea uncommonly well; and it consists of several varieties, all of which do well in sand or in poor soils, not really thriving so well in either wet or fertile soil, for in these the shoots are more succulent, and do not get thoroughly matured, and are thus less able to bear the severe weather than loose vigorous shoots, the product of a dry, poor soil, or of sand, being particularly well adapted to grow in the latter, possessing long bare roots which do not admit of its being trunsplanted so successfully as other varieties whose roots are improved by transplantation, a two-year old seedling plant seldom taking root when removed; the best plants to $u$ 'e being those that have stood in the seed-bed for one year only, and one year more in nursery lines, which brings them up to two years of nge, this very peculiarity specially adapting them for growing in sand, in which they are able natn ally to throw out numerous fibres of their own accord, which they wonld be unable to do in a more retentive soil. The long root strikes down to a great depth, and thus in a measure the tree becomes independent of drought and the casualties aring from a shifting surface, which would be fatal to many other varieties. 


\section{2}

ENGLISH TREES AND TREE-PLANTING.

In pure, shifting, dry sand, as well as the pineaster, the native Scotch pine, the Black pine of Austria, and the Corsica pine will all do well; and if the site is not too close to the sea, but removed somewhat from its influence, larch interspersed among these will also answer, and if these are employed, one-year seedlings, one year transplanted, or twoyear old seedlings, one year transplanted, should be used. In very dry situations the firs should be planted in September, and the larch at the end of October, or all may be planted during open weather in winter, or early spring, the plants being placed two to three feet apart; and an open cover of brushwood spread over the surface will be found a great protection and help to the young plants.

If the ground is not very dry, and a good deal exposed to the influence of the sea, the best time for transplanting the plants will be in the month of April, and pines are specially well adapted for sandy situations. In a heavier description of soil, which is sometimes found near the sea-shore, there are other trees suitable for maritime situations, as the goat-willow, the Huntingdon willow, and the Bedford willow, all of which will stand a sea-exposure very well, the variety of willows being very considerable.

The common alder and beech may often be employed, as well as the common sycamore, the Norway and scarlet maple. The grey poplar may also be used, but none of the other varieties of poplar. As living screen fences the black elder, as well as the scarlet elder, are very efficacious, and these will stand 
e pinebine of 11 ; and moved among loyed, $r$ twould be ald be end of eather placed brushgreat

d deal time nth of sandy which e are as the dford very able.

e emorway so be As s the stand

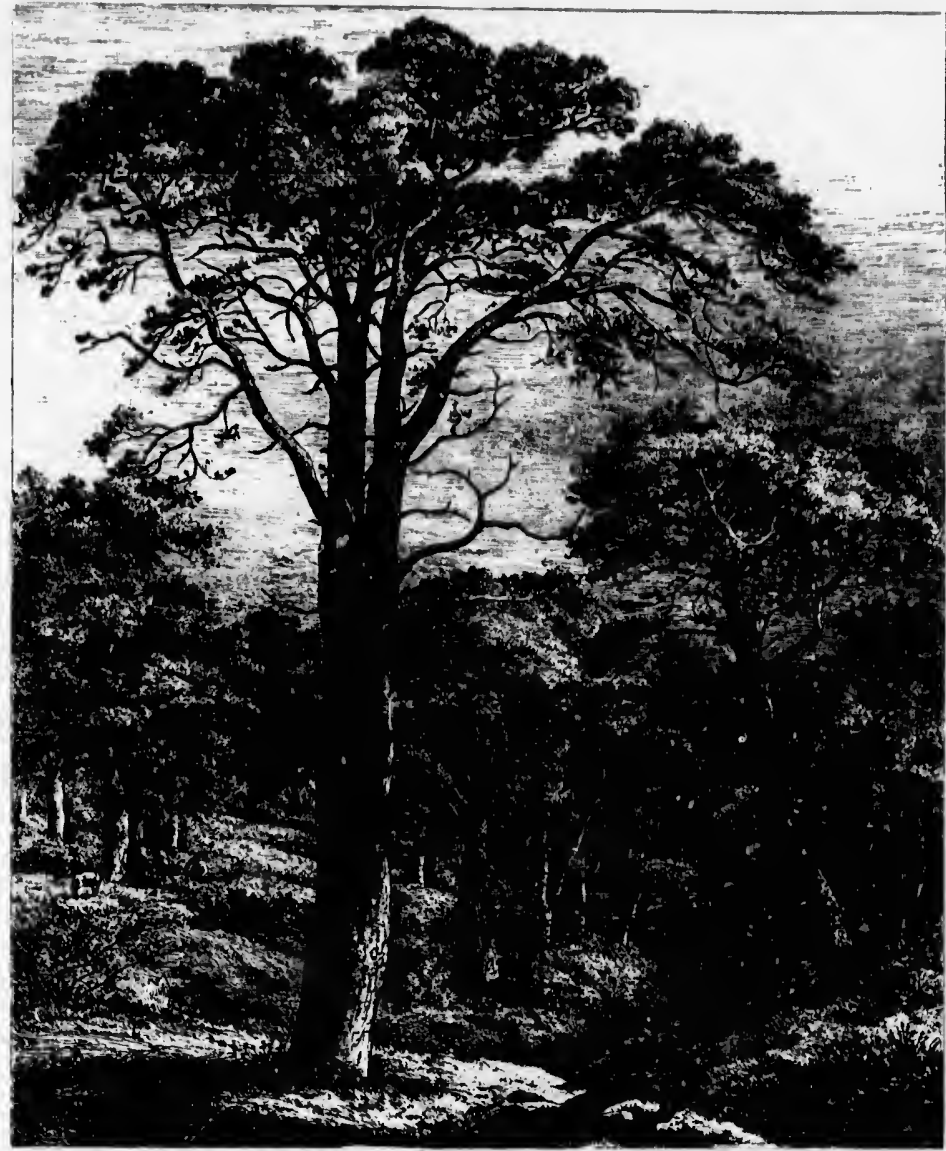



the first brunt of the sea breeze, and temper the wind to the more valuable trees that follow in rotation. It may be commonly scen in maritime situations in the case of plantations of trees, that the outer ones exposed to the influence of the wind are disfigured in shape, and bent in accordance with its prevailing current, as well as being dwarfed and stunted; but as the plantation advances, the trees become taller, and of better figure, so that a sloping line might be drawn of gradually ascending trees, as they are farther removed from the influence of the sea-exposure. An outer belt of elder trees-a tree of very humble pretensions in the ordinary way-will thus be found to render effectual service as a nurse to the more valuable varieties.

Among the low growing shrubs which stand seaexposure well will be found the sea-buckthorn (Hippopho rhamnoides), the snowberry (Symphoricarpos racemosus), the evergreen barberry (Mahonia aquifolia), and the German tamarisk (Myricaria Germanica). The latter makes a capital hedge, and although not generally attaining any considerable size, the stems will sometimes arrive at the dimensions of a tree. One of these may be seen growing against the side of the small inn called the Captain Digby, which stands at the edge of the cliff at Kingsgate, in the Isle of Thanet, near the North Foreland lighthouse, that has a stem the thickness of a man's thigh, and in many seaside places the German tamarisk may be seen forming a pretty green hedge of a highly ornamental character. 


\section{CHAPTER XX.}

HEDGES.

OLD-FASHIONED ENGLISI HEDGES- -VARIETIRS OF HEDGE PLANTS-THE HAWTHORN-PLANTING THE 'QUICKS'-PRUNING-THE CRAB TREETHE RLACKTHORN-BEECH HEDGES: CULTIVATION-TBE HORNBEAM -THE MAPLE-HEDGES FOR WET OR BOFGY LAND-HOLLT HEDGES - FURZE HEDGES-ASCENT OF THE SAP IN TREES.

THE old-fashioned English hedge-row, lofty and wide-spreading, and frequently occupying about a quarter of the field it was originally planted to enclose, was often a picturesque object at various seasons of the year, gay with the wild rose at one time, and at another nearly sinothered with the white blossoms of the hawthorn; but these are fast disappearing in many parts of Great Britain, the exigencies of modern husbandry not permitting their existence any longer in the form they used commonly to be met with, when the soil was less valuable than at present.

Although a certain pang of regret is sometimes felt at the gradual disappearance of these ancient hedges, whose lot it is to be sacrificed to the necessities of the age, and the progress of improved husbandry, it must be confessed that, in addition to the waste of valuable land they occasioned, they 
were great harbourers of vermin, and for these oldfashioned, wide-spreading hedges the neatly trimmed one about a quarter their size has now to be substituted in those situations where hedges are required for shelter, which will interpose no obstacle to the free action of sun and air upon the growth and ingathering of the crops.

Varieties of Hedge Plants.-The plants most suitable for the formation of heciges are, first the hawthorn, which, from its quick growth, long life, rigid habit, and stubborn character, as well as its readily adapting itself to most kinds of soils, has recommended itself to the notice of most planters throughout England; next the crab-tree, which used to be a favourite hedge-plant with the two or three last generations of English farmers that have passed away; the blackthorn, still more extensively used, the sour fruit of which (sloes) country children were in the habit of gathering and eating; the beech, which, on account of the shelter it will afford, is well worthy of being more extensively used than it is by planters, for liedges of beech can easily be trained to stand in a comparatively narrow space from fifteen to five-and-twenty feet high, retaining their leaves during the winter in a withered condition; the hornbeam, which was also a favourite hedge-plant with our ancestors, also retaining its foliage, but not for so long a time as the beech; and the maple, which will conclude the list of deciduous hedge-plants that are commonly used in this country. 
The evergreen hedges comprise the holly, which is first in importance; the furze, which, although regarded as a very inferior hedge-plant, is made use of in some localities. and is a handsome object with its rich, gold-coloured blossoms, which are displayed throughout a great portion of the year; and the privet, which latter stands the smoke of cities well, and also the drip of trees. Other trees are occasionally made use of for hedges, as the yew and box, but they are not sufficiently free growing to be in general request.

The Hawthorn (Cratcegus Oxycantha).-A description of the method of raising hawthorn plants has been given before, and these vary very much in size after one season's growth, from six to nine inches being generally considered a fair height for the hawthorn to attain; but by good management in a soil particularly well adapted for them, they will sometimes rise a couple of feet ligh during the first season, after which they take the name of 'quicks,' or ' quicksets.'

Planting the Quicks.-The ground should be trenched two spits deep along the site of the intended hedge, three or four feet wide, and some well rotted farm-yard manure forked in, which should be done some little time previous to planting.

The tops of the plants should be cut off two or three inches above the soil-mark, which will be readily perceived upon the stem, and the top roots should be shortened, but none of the fiblous roots 
ly, which lough rede use of t with its displayed $l$ the priwell, and asionally box, but general

descripants has h in size c inches the hawin a soil Il somehe first quicks,'

ould be ntended 1 rotted be done

two or will be cut away. The plants should then be inserted in the trench made for their reception, standing six inches apart, the soil being drawn towards their roots to keep them in their places without force or pressure being used to squeeze in the roots. For the first four or five years the health and vigour of the hedge will mainly depend on the proper preparation of the soil, and its being kept slear of weeds. Hedges or fences are commonly associated with ditches and banks in accordance with the various requirements of different localities, and are often protected with posts and rails, and other contrivances during the carly period of their growth ; but we need make no mention of these, which usually are included under the heading of farm operations; but after the quicks have been planted, and the weeds appear, both sides of the young hedge should be carefully hoed over, for the double purpose of killing the weeds, and smoothing over any irregularities of the soil, as well as loosening it, so that it may enjoy the advantages of the rain and dews that fall; and this hoeing should not be deferred, but done early in the season, about April, and repeated during the summer, as well as in autumn.

If the weeds are allowed to grow large, they will deprive the young hedge of a great part of the nourishment it ought, in receive, as well as calling for a heavier stroke from the labourer performing the work, and the risking of a stray blow or two falling upon, and injuring, the hedge-piants. The early re- 
moval of weeds in the season, and following it up afterwards cluring the summer and autumn, as recommended, will be found of great ultimate benefit.

A variety of methods of practice prevail as to the pruning of hedges; some people cutting them during the first yoar of their growth, while others defer it till the second, third, fourth, or even fifth year, but it will be found the best plan not to cut them during the first season, unless they have grown more than a foot high. If they exceed this, however, it may be desirable to cut off their tops to the height of a foot or eighteen inches. If pruned too immoderately, early pruning is without doubt likely to be injurious; but if, on the other hand, it is deferred too long, the hedge is api to grow naked at the $\mathrm{b}$ som. At the end of the second year's growth matters will have assumed a more definite form, and the hedge should then be trimmed so as to stand a foot or eighteen inches above the previous year's growth, and any of the lateral side shoots which extend more than fifteen or eighteen inches from the stems of the plants should have their tops cut off. This will have both the effect of thickening the hedge in its natural growth, and will prevent the accidents which often arise from the heavy weight of snow which sometimes falls upon them, which they are unable to bear; and the same practice should be followed the third year, the hedge being cut with a. smart stroke of the bili upwards, so as to shape it somewhat in the form of a cone, gradually narrow- 
$\mathrm{ng}$ it up is recomefit.

ail as to ing them le others ven fifth ot to cut ve grown his, howps to the uned too bt likely nd, it is naked at s growth orm, and o stand a us year's hich exfrom the cut off. ning the vent the weight of iich they hould be at with a. shape it narrow- ing towards the top, which will be the strongest form it can be inade to assume.

Pruning.-By treating the hedge after this fashion, it will be closer at the bottom, and have fewer gaps in it, than if the pruning is deferred till three, four, or even five years, which some writers insist upon. It is true that the stems will not run up so tall by this method, but the development of growtl in the shape of a tall stem means a thin bottom to the liedge, the naked stems having no side branches.

When the object is to raise an occasional tree at certain distances in the hedge, the proper course doubtless to ensure this end would be to leave the top alone, and treat it in the same manner as would be followed in developing the growth of any other tree, which then becomes no longer a hedge-plant. Where these gaps occur in the lower part of a hedge, hares and rabbits, dogs, pigs, and other depredators which have the chance, force their way through them, and the hedge, for purposes of chief utility, is destroyed; a thorougl good hedge requiring to be dense and bushy at bottom, capable of iestraining the attempts of intruders to force a way through.

By this method of treatinent, a fence of hawthorn, at five years of age, will keep back any kind of cattle; but after three years of age, an annual trimming will be required to keep it in proper bounds and shape, the best time for cutting being either October or March, the wood being softer and more easily cut in the latter month than in the former.

$$
\text { F } E 2
$$


As the hawthorn will in time assume the dimensions of a tree, and if not prevented, shed its bottom limbs, and spread out its upper branches, and form the ordinary spreading liead that trees assume, it is found necessary after certain intervals of time, according to the quality of the soil, to cut it down, the period varying from ten to fifteen years, either partly or wholly. Hedges are also cut down or reduced to three feet and a half to four feet at times, which operation is called breasting; and also entirely to the surface of the ground, in order to renew them, which is an effectual way of doing so where the roots stand sufficiently thick together to send up young shoots enough to form a complete fence. Laying and plashing are also performed, with a view of renewing hedges, as well as other methods of treatment which scarcely corre within our province to allude to, forming, as it does, a part of farm routine or labour, which we do not profess to speak of upon this occasion.

The Crab Tree (Pyrus malus). - The crab-tree is generally considered to follow next in point of usefulness to the hawthorn, but it does not make nearly so impervious a fence. It is more subject also to discase, as the attacks of American blight, as well as those from various aphides, caterpillars, \&c., which in some seasons will entirely spoil the appearance of a hedge. Where plants are required to be reared for the formation of hedges, the crabs or fruit require to be gathered in October, when they become ripe, 
dimen-

bottom nd form ne, it is me, acwn, the either own or t times, entirely w them, ne roots young ing and enewing t which ude to, labour, on this -tree is of usenearly also to well as which ance of reared require e ripe, and laid in a heap all through the winter to rot, for the purpose of separating the pulp from the pips, or seeds, the heap being turned over three or four times in the course of the winter to cause the pulp to become thoroughly decayed.

By March this will have become effected, when the proper time for sowing will have arrived. Drills should be drawn for the reception of the seed, and some sand mixed up with the rotten mass to separate the seed from it, which is best done by rubbing it through the hands, so that it may be equally distributed along the drills; the same course of culture being followed in the preparation of the ground, hoeing, \&c., as prescribed for the hawthorn.

When planted in rows in wursery lines, they should stand fifteen inches apart, and the plants be two or three inches from one another in the rows: the stoutest will be strong enongh to be planted out after having stood in nursery lines for one year, but the weakest will have to remain for two or three years; they require to be grown with a free growth, and not be allowed to assume a stunted habit, from which there will always be a great difficulty in recovering them. They need to be planted in the hedge entire, without cutting, until they have established themselves for a year in their permanent situations ; they will then throw out numerous shoots, and be stout and strong in proporticn, and frequently reach the lieight of four feet in the course of the first year, being proportionately bushy. 
The seeds of the apple should not be used for raising hedge-plants, for although the fruit will only be crabs, they never grow with the vigour of the wild stock. Nurserymen use these to graft apples upon, on account of their making dwarf standards upon which to graft the cultivated apple, a large number of these seels being produced in Herefordshire and other cyder districts that have escaped the crushing of the cyder seed, and are sold to nurserymen to raise stocks from. These stocks can be readily recognised by their large leaves, and from their being almost without spines.

The Blackthorn (Prunus spinosa).-The blackthorn was extensively used as a helge-plant at one time, as may be seen from the numerous remains of old hedges all over the country; but its sprays are neither so numerous, nor so sharp as those of the hawtliorn, and is consequently very inferior, except in certain situations, for, being of free growth and very hardy, it answers well in positions of great exposure, and also in a damp soil when liawthorn would not succeed so well.

It is a useful plant to employ in filling up the gaps in old ledges; but if made use of for this purpose, plants that have been raised from seed should be used, as they are less liable to throw out suckers than suckers themselves, the tendency of the blackthorn to throw out these being one of the principal objections to its use, as they prove injurious to the neighbouring crops. 
ed for

ll only of the apples ndards large reforded the urseryan be from

blackat one ins of iys are of the except $h$ and great vthorn

ip the

$r$ this seed w out of the of the ve in-

The $n$ get lipe in October, when they should be gi hu'ed and put up into a heap to rot, and allow $i$ to remain until the spring, being turned over a lew times in tine ir rrval The eariy part of Mry is generally considere ne west time for sowing the seeds, but the sowing should not be deferred later than the $e^{\text {r }}$ of May. The same method of treatment is pursued with the young plants as followed in the case of the hawthorn; but as they grow stronger than the hawthorn, and have long tap roots, they should not be allowed to remain in the seedbed for two years, on accunit of its root, which is likely to get damaged in the course of removal after it has attained a certain size, which nay be the occasion of killing the plant. They should, therefore, be transplanted into nursery lines after they have completed the first season's growth, the plants being moved as carefully as possible, so as not to disturb the ground, which should be afterwards made smooth with a rake, as a second crop of plants will often make their appearance as good as the first.

The blackthorn may often be made use of when. associated with other trees, forming excellent cover, its spines being useful to repel intruders, but as a hedge-plant, pure and simple, it is very inferior to the hawthorn.

Beech Hetges.--The beech (Fagus sylvatica). When a tall hedge is wanted, capable of giving shelter to farm buildings, or indeed anywhere where it may be required, the beech is a tree well worthy of being 


$$
\text { - }
$$



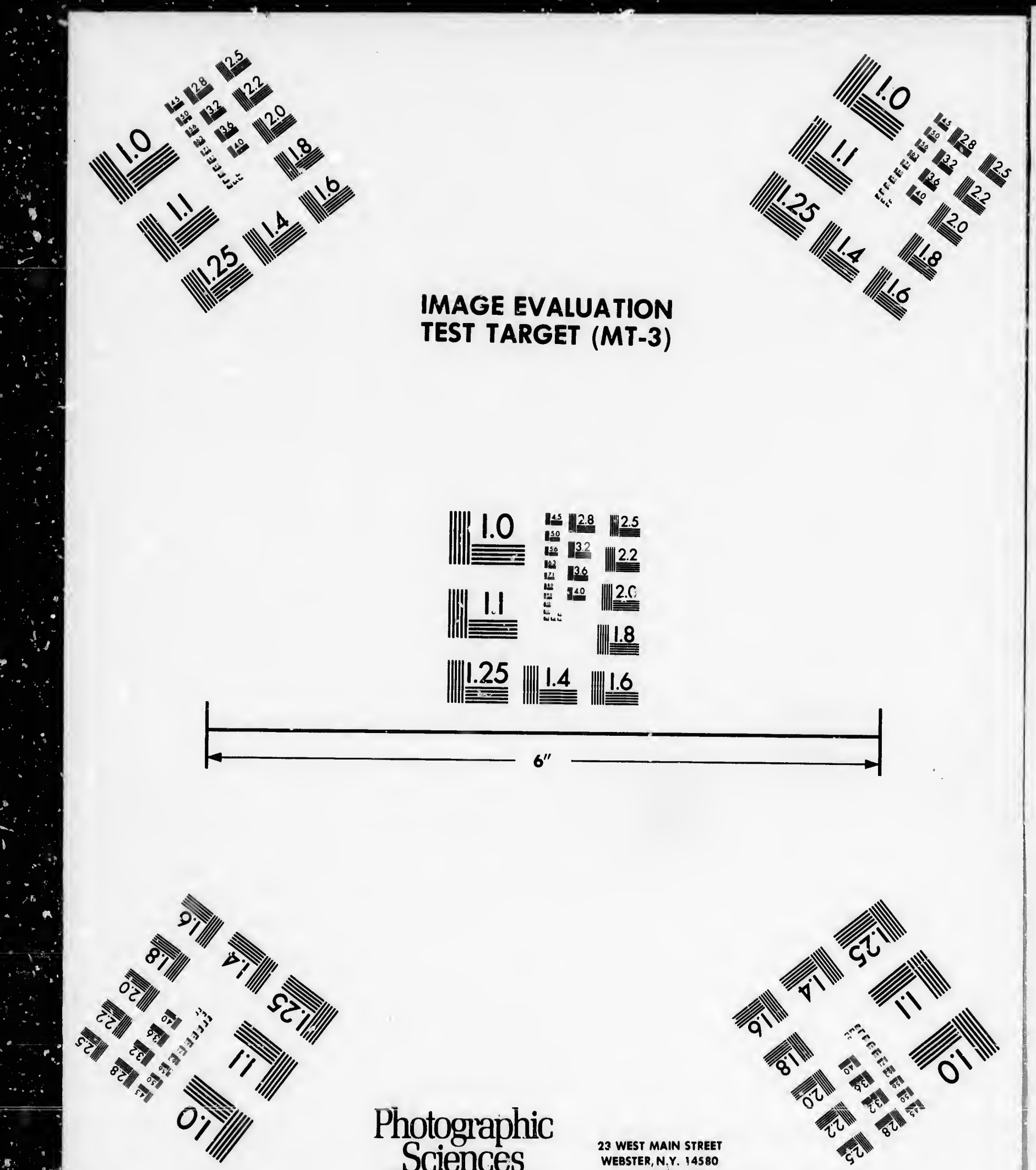

Photographic Sciences Corporation
23 WEST MAIN STREET WEBSTER, N.Y. 14580

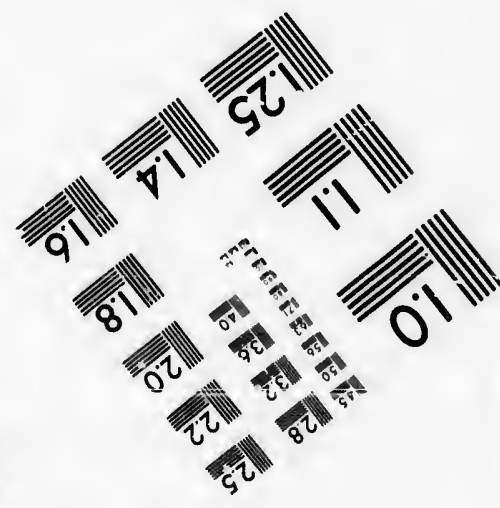



more extensively made use of than obtains at present. It is nearly as good as an evergreen, from the fact of its retaining the leaves upon its branches in a withered state; and it may be trained to any height - thirty feet, if necessary.

Upon the Continent, beech heuges are often formed in the shape of trellis-work, the young trees being planted about eight inches apart, in a slanting direction, crosswise, at an angle of forty-five degrees. Sometimes the bark is peeled off at the parts of contact, and the two are thus inarched together; being kept in proper position in the first place by the withies with which they are tied; thus forming a hedge of a most interesting as well as an useful description.

Beech hedges require to be well trimmed, and not allowed to run wild; the best season for trimming or cutting them being the summer; though this is opposed to the notions of a good many people who think that it causes bleeding; but if cut in the month of July, the piants will throw out numerous buds and shoots, which will give greater density to the hedge. Any awkward side-shoots that make their appearance should be cut off.

The beech-mast gets ripe in November, and it is generally gathered after it falls from the trees. The seed should be sown in drills, and covered with soil about the thickness of an inch in February or March, which is the best time for sowing. In the succeeding winter, the seedlings must be transplanted into 
present. fact of $\mathrm{s}$ in a height

formed s being direcegrees. f conbeing oy tha aing a ful de-

$d$, and nming this is e who n the ierous ity to their

it is The h soil arch, ceedinto nursery lines, which stand about a foot and a half asunder, the plants standing three or four inches from each other in the rows. They should remain in nursery' lines for a couple of years, when they will mostly have attained a height of eighteen inches to two feet, when they will be ready for permanently planting out; but another transplantation into wider nursery lines will improve them considerably and add to the strength of their roots, and they may remain two or three years longer without injury to their final transplantation, as would be the case in the instance of some trees, and by using forward plants a larger hedge can be more readily obtained. While the young trees are in the seed-bed, they should be kept clear of weeds in the usual way. In fixing a site for a permanent hedge, the land should be dug for a width of three feet, and sufficiently deep to permit of the roots being laid down without injury, the roots not to be pruned after the first year.

Tive Hornbeam (Carpinus betulus).-The hornbeam also makes a capital hedge in exposed situations, being able to endure rough winds; but it will not thrive on many soils, loams and clay suiting it best, but not succeeding in chalk, where the hornbeam refuses to grow, the beech often growing luxuriantly. The foliage is not so long retained as the beech, but it stands pruning well ; and while it will form as large a hedge as beech, it will not be so strong, nor afford the same amount of shelter.

The seeds when gathered ripe in October require 
to be laid in a heap to rot for twelve months, being sown in the same way as beech-mast, but with a smaller amount of cover, half an inch depth of soil being sufficient. When the young plants make their appearance, the treatment needed is the same as that required for the beech.

The Maple (Acer campestre).-The maple, although occasionally used as a fence, is very inferior to those which have veen previously mentioned, as it affords comparatively little shelter, and the leaves do not remain attached to the branches in a withered state.

Hedges for wet or boggy land.-Where the land is wet or boggy, the plants to have recourse to for the formation of hedges are the willow, birch, alder, and elder. All of these will grow readily from cuttings, except the alder, nothing more being required than taking off the shoots, and dividing them into lengths of about twelve inches long, and inserting them in the ground in a straight line, or in the form the intended fence is required to assume. A willow fence is easily made by cutting off good shoots three or four feet in length and inserting the cuttings in the ground, lattice fashion, in the same way as described for the beech, with horizontai rods fastened along the top to keep it firmly in its place, which will require a good deal of trimming to keep it shapely; but this the willows will bear remarkably well, and can be done at any time, no cutting appearing to injure its vitality to any appreciable extent.

Holly Hedges.-The holly (Ilex aquifolium) has 
, being with a of soil e their as that

hough those affords not reate.

land is or the $r$, and ttings, than engths em in he infence ee or in the cribed Ig the equire th this an be rre its been before described, and allusion made to holly hedges, but a few more details are necessary with respect to planting, pruning, \&c., which it will be desirable to furnish. Good holly hedges are sometimes injured by being cut at the wrong time of the year, many persons performing this operation at the beginning of winter, which, by removing the foliage, exposes the stems of the plants to the frost; the best time for cutting evergreen hedges of all kinds being in the course of the spring, after the frosts have gone, or during summer. Whenever the hedge is trimmed it is impossible to use the shears without in some degree injuring its appearance, as the leaves must necessarily be cut; but if this is cone in the summer time about midsummer, or even a little later, the aftergrowth covers over the cut leaves and bare ends of twig, and the bedge in consequence wears a smoother and handsomer appearance, it being necessary to use shears, and not a bill-hook in trimming a holly-hedge, as the leaves are so tough and thick as to resist the hook ordinarily used in cutting hedges.

After the seeds are sown in the seed-bed in March or April, a few branches of evergreens laid over them, to protect the rising plants both against frosts and the influence of the sun, will be found advantageous. It is generally supposed, as a matter of course, that it is the best plan to remove the shading materials durirg a fine sunny day, so that the young plants may receive benefit, but the heat of the 
sun is injurious to holly plants that are just emerging from the ground.

They require to stand in the seed-bed for two years, and then be planted out into nursery lines, twelve inches asunder, the plants standing in the rows two or three inches from one another. The holly requires to be transplanted either in the month of May or August and September. If planted earlier in the year than May, there is a great chance of their not succeeding; and if planted later than September there is also equal risk, failures during the winter months being very common with the holly. After standing in the nursery lines for two years (they may be allowed to remain for four years, but not longer, without transplantation) they must be again placed out into nursery lines, standing a foot apart from each other in the rows, the spaces between the rows being proportionately wider. They will be about fifteen to eighteen inches high about this time, the holly growing but. slowly, but the transplantation will give them bushy, fibrous roots which are highly necessary for their future welfare.

The ground should be well trenched and manured ready for the reception of the young plants, along the site of the intended hedge, in the same way as prepared for the hawthorn, and a dull or rainy day be chosen for setting the plants. A garden line should be stretched along, and a hole dug witli a spade, large enough for the roots of the first plant to be laid in it without being cramped, and a second 
hole should be dug farther on, a foot apart, the labourer working backwards; the soil from the second hole filling up the first one, the third the second, and so on till the whole row is completed, the soil being made firm before it is put round the roots of each plant. They should afterwards be trodden down firm with the feet, each plant being held in the hands while this is being done, to keep it in an upright position.

The young trees must be kept free of weeds, and the ground well hoed, the holly well repaying all the attention that can be bestowed upon it. The young hedge will not require any pruning for the first two seasons; but af ierwards the side shoots will require a little trimming, so as to direct the growing hedge in a shapely form, the most suitable being generally considered to be with a rounded top, and not a flat one, of about a foot in width, the bottom being three feet wide in a mature hedge.

If the plants receive a severe check in planting which will sometimes be the case if transplanted in dry weather, when it becomes advisable to dip the roots in water before planting them-they will assume a stunted appearance, and it will be the best course then to cut them down in the beginning of April, which is the only safe time in which to perform the operation, care being taken not to cut the stems lower down than the ground-mark. The cutting will cause the plants to throw out strong healthy shoots, and the hedge will progress faster than if left to 
recover itself without such treatment. If this needs to be done, at the same time the soil should be dug over between the plants, and made thoroughly clean, and freed from weeds, if there are any. When the ground is poor also, manure will be of great assistance to the plants, and cause them to grow stronger; holly growing in almost every soil tolerably well, excepting wet ones, but it takes eight to ten years to make a hedge four to five feet high, which is a drawback, but it makes one of the handsomest and best of hedyes, and is an object of beauty at all times, with its evergreen foliage, particularly appropriate for gardens and pleasure grounds.

Furze Hedges.-The furze (Ulex Europea). Very few people would think of making use of a furze hedge from choice, yet in sandy and other positions where there is a great diffic ${ }^{1+} \mathrm{y}$ in establishing trees, the furze hedge is not to be despised, and is often really a very ornamental and handsome object, being covered with a profusion of yellow blossoms throughout the greater part of the year. Upon a raised bank, covered with ivy which can be made to grow, the furze hedge looks remarkably well, and becomes sufficiently ornamental for the neighbourhood of dwelling-houses that have been fixed in these situations for the sake of a healthy site, good drainage, or high position.

A bank should be thrown up two and a half or three feet high, made flat on the top, along which a drill should be drawn, in which the seeds should be 
is needs be dug y clean, ien the assistronger ; y well, rears to a drawad best times, opriate

Very

furze ositions trees, s often , being roughraised grow, ecomes od of situaainage, alf or hich a ald be sown in March or the beginning of April. During the first year the plants will reach a height of nine inches or a foot; and they require no attention till the second year, when their tops need cutting over with the shears, the best time for doing this being the months of April or May, and this operation should be repeated every year afterwards, at any time during the summer months, but the hedge should not be cut in the winter, as frost frequently kills furze. The constant summer cutting will prevent the furze from getting bare at the bottom, or wearing that dead appearance which is otherwise a great drawback to its good looks. If furze-plants are used instead of seed, they should be planted nine inches apart.

The presence of evergreens in the form of trees, no matter how employed, is a great finish and adornment to any landscape, especially in those of circumscribed dimensions, which lack the grandeur that mere space often confers. It was at one time a common error that evergreens never parted with their leaves, which may be traced back to the mythology of the Greeks; and thus Theophrastus relates that, in the country of Cortynia, in Crete, a plane tree was stated to be growing by a fountain, which never shed its leaves, beneath the shade of which Jupiter was said to have had his interview with Europa. Yet it has been remarked before by writers that Theophrastus was himself acquainted with the fact of the fall of the leaves if evergreens, as every accurate ob- 
server of nature must be, though they do not actually fall till the young leaves have begun to appear; so that trees of this sort are never left wholly without leaves, and by a mixture of evergreeus with deciduous trees, we are certainly in this country enabled to obtain the most delightful arboricultural results.

In Darwin's 'Natural History of a Voyage to South America' it is said that_- In South America, Australia, and the Cape of Good Hope, the trees are all evergreens. The inhabitants of these, and the intertropical regions generally, thus lose, perhaps, one of the most glorious, though to our eyes common spectacles in the world, the first bursting intc full foliage of the leafless tree. They may, however, say that we pay dearly for our spectacle by having the land covered with mere naked skeletons for so many months. This is true, but our senses thus acquire a keen relish for the exquisite green of the spring, which the eyes of those living within the tropics, sated during the long year with the gorgeous productions of those glowing climates, can never experience.'

It has been observed that, generally speaking, the trees whose leaves are expanded soonest are those which lose them earliest, as may be seen in the lime, horse-chesnut, and some other trees ; the rule, however, having its exception in the case of the elder, its leaves appearing early in the season and falling very late; while the common ash is peculiar on account of coming late into leaf, and the leaves faliing from the tree at the end of summer. 
Areent of the Sap in 'Trees.-The leaves of 110 st deciduous trees fall upon the approach of winter; but cold is not considered the principal cause of this natural phenomenon, but is to be attributed principally to the course of the sap being interrupted, when the vessels of the leaf dry up and contract, and soon after fall. The physiologists of past generations were very much in doubt through what part of the stem the ascent of sap was annually made, some supposing that it took place through the bark, and others that it passed through the pith. But experiment and observation showed that the progress of the sap was not arrested in trees that had been deprived of their bark, while in the case of some hollow trees the sap regularly ascended, and certain boughs were annually covered with leafy verdure.

It is now, however, fully understood that the course of the sap lies through the woody layers; and in such trees as have only a small cylinder of woody layer left, the sap will perform its allotted course without interruption. Coulon discovered this fact through an accidental circumstance while having a row of large poplar trees cut down. In one tree which had been circularly sawn, that had fallen, but which still held to its stump by its centre, he saw bubbles of liquid and air rising upwards from the inner fibres, and giving out a distinct sound. This led him to try various experiments on those trees which still remained to be felled, and upon boring them with a large auger, he discovered that the frag- 
ments which were taken from the outer layers of the wood were almost dry, but they became more moist as the auger penetrated more deeply; and when it arrived at the centre of the stem, the sap began to flow out at the surface, thus proving that the ascent of the sap takes place in the woody layers, its course being mostly developed in those which lie the nearest to the medullary canal. The result of these experiments was communicated to the Academy of Sciences, and they were repeated by Desfontaines and Thouin, who confirmed its accuracy, and thus, sccording to Longfellow-

From the earth's loosened mould

The sapli ig draws its sustenance and thrives;

Though s. icken to the heart with winter's cold,

The drooping tree revives.

The softly warbled song

Comes from the pleasant woods, and coloured wings

Glance quick in the bright sun, that moves along

The forest openings.

When the bright sunset fills

The silver woods with light, the green slope throws

Its shadows in the hollows of the hills,

And wide the upland glows. 


\section{SMITH, ELDER, \& C0.'S PUBLICATIONS.}

of the moist hen it gan to ascent course learest experiiences, houin, ing to

\section{Under the Sanction of Her Majesty the Queen.}

In Five Volumes, demy 8ro. price 18s, each.

THE LIFE OF HIS ROYAL HIGHNESS

THE PRINCE CONSORT.

By SIR THEODORE MARTIN, K.C.B.

With Portraits, a Facoimile, and an Index.

NEW VOLUME BY ROBERT BROWNING.

Fep. 8 vo. 58 .

DRAMATIC IDYLS. SECOND SERIES.

By ROBERT BROWNING.

LiFE OF Lieut.-GenERAL SiR JAMES OUTRAM. By Major-Grankal Sir FREDERIC J. GoldSMID, C.B., K.C.S.I.

2 vols. demy 8 vo.

A BELEOTION from the POETRY of ELIZABETH BARRETT BROWNING. Second Series. Uniform with the First Series. Crown 8vo. 7s. 6d.; gilt cdges, 8s, $6 d$.

A SELECTION from the POETICAL WORKS of ROBERT BROWNING. Second Series. Uniform with the First Serics. Crown 8vo. 7s. 6d.; gilt
edges, 8s. 6d.

PABSAGES from the PROSE WRITINGS of MATTHEW ARNOLD. Crown 8vo. 7s, 6d.

SHAKSPEARE'S KNOWLEDGE and USE of the BIBLE. By CilARIEs WordswokTH, D.C.L., Bishop of S. Andrews, and Fellow of Winchester College. Third Edition. With Appendix, eontaining alditional Iliustrations and Tercentenary Sermon
prcached at Stratford-on-Avon. Crown 8vo. 7s, 6d.

PHILOSOPHY of CHARLII DIOKENS. By the Honourable ALRERT s. G. CANsiNG, Author of ' l'hilosophy of the Waverloy Novels,' \&e. \&c. Crown 8vo. 7s, 6d.

MIXED ESSAYS. By Matthew Arnol.d. Second Edition. Crown 8vo. 9s.

REASONABLE SERVICE. By W. PAGE RoBerTs, MI.A., Incumbent of S. Peter's, Vere Strect, formerly Vicar of Eye, Suffolk, Author of ' Law and Goll.' Fourth
Edition. Crown $9 v 0.6 s$.

ALLAOODDEEN : a Tragedy, and other Poems. By the Author of 'Constance'se. Crown 8vo, 6s.

NEW and OLD : a Volume of Verse. By John Adpington Srmonds, M.A., Author of 'Renaissance in Italy.' Crown 8vo. 98 .

RENATSSANCE in ITALY: Age of the Despots. By Joun AdDingToN SrmosDs, M.A. Second Edition. Demy 8vo. 16s.

The POETRY of ASTRONOMY. By Richard A. Proctor, Author of 'The Borderland of Science,' 'Scienee Byways,' \&c. \&o. Crown 8vo.

Tho POWER of SOUND. By EDmond Gurngy, late Fellow of Trinity College, Cambridge. Rogn $8 \mathrm{vn}$.

London: SMITH, LLDER, \& CO., 15 Waterloo Place. 


\section{RURAL ENGLAND.}

'A series of books of really incomparable freshness and interest.' - AтHLN suм.

'Books unsurpassed in power of observation and sympathy with natural objects l'y enything that hus appeared since the days of Gilbert White.'-DAILY Nuws.

Large crown 8 ro. $108,6 d$.

\section{THE GAMEKEEPER AT HOME;}

OR, SKETCHES OF NATURAL HISTORY, POACHING, AND RURAL IJE.

A beartifully ILLUSTRATED EDITION, with 41 Illustrations specially drawn for the work by CliarLes WHYMPER.

"The great merit of "The Qamekeeper at Home." as of its companions, is that they are eminently trutliful and practical, as well as delightfnlly descriptive. 'The library of good hooks ou. the country is not so large but that anv additious qre exceedingly welcome; and since White wrote his "Ninturu? History of Selborne" we have had nolhing more dellghtful than "The Ganiekeeper at Home" nnd "Wild Life in a Sonthern County." They are cheap enough to be within the reach of all ; they aro portable enough to be carried in the pooket; yet they contain a great variety of infornation, given in a plossant thongh gossipy style, and are the very books to be on the slielves of the country gentleman among those that he treasures for constant reference. - EDINBURGH liEvikw.

*** Also, the THIRD EDITTON, without Illustrations, crown $\mathbf{3}$ vo. 5 s.

WORKS BY THE SAME AUTHOR.

SECOND EDITION. Crown 8vo, 7s. 6d.

\section{WILD LIFE IIN A SOUTHERN COUNTY.}

"Even a "i ire delightful book than " The Gamekeeper at Home." It is diffienlt to give more than the vaguest. A of a volume so full of interesting matter. It must be defined as a mullum in paivo encyclopædia of country sights and country matters. Tho autbor is at once the closest and the most catholic of observers. Nothing escaped him in the enimate creation; he is also intensely interested in the phenomena of the atmosphere and tho wenther; and he has nuch to tell about the liabits of the country people and their odd and primitive ways of thinking. Open the book where you mity you cannot fail to find something attractive; and as it is imposeible to do it reasonable justice in a review, we can oniy recommend our readers to procure it.'-SATURDAY REVIEW.

Crown 8vo. 5s.

\section{THE AMATEUR POACHER.}

"More enjoyable thau its predecessors. Wo lave tho most clelicate painting of the minutest details of our rural landscespes, with realistic sketches it eloquent langunge of tho changirig seenery of English seasons. It is full, too, of the lively autobiographic al reminiscences which always give truth and colour to a book. We advise all lovers of the country to get "The Amateur Poacher " and read it for themselves.'-SATURDAY REVIEW.

\section{Crown 8 ro. $7 s, 6 d$. \\ GREENE FERNE FÁRM.}

\section{By RICHARD JEFFERIES.}

'Mr. Jefferies is as fascinating as ever. Nothing can be more true to the life than his minute descriptions of rural scenery, or of the idiosynctacies, manners, nud talk of the rustics in a seclinted parish under tho slopes of the Downs. . . . Having all the merits and charms of the author's peculiar style, the book makes as enjoyable reading as any of his other volumes.'-THE TISFs.

Two vols. crown 8 ro. $12 s$.

\section{HODGE AND HIS MASTERS.}

by RICHARD JEFFERIES, Author of 'The Gamekeeper at Home' \&c.

'Two pleasant volumes. ... Delightful peeps are here and there obtained of waving wheat ficlds, or an old-fashioned farm-house, as morning lifts round Hodge's karder?; in another aphere of art wo should look in vain for their homeliness and benuty anve on the canvares of Millet.'-ACADrisy.

'A complete account of all the element3 that go to mako up the agrleultural population of England. We have pictures of every class who live beyond cities. . . A description of rutral life as accurate as it is artistic, as practica? and useful as it is pleasant and attractive. This last work of the talented and keen observer has a value far surpassing his pre vious ones. ... Nothing so gool lins ever been written on the subject, nothing in the lenst ajproaching to it. The hook possesses a charm and a fresnness of its own, which forms a graceful setting to the many valuahlo pens of information it contains ; and it will extend in cities a knowledge of the wants, of the 'eficieneics, anil of the virtues of our agricultural population.'-EXAMINEn.

London: SMITII, ELDER, \& CO, 10 Watgion I'lice. 
SNAT.

al objects ly s.

RAL LIEE. ecially

are eminently 1. tho country his "Naturu? Home" and all ; they are niation, given ountry gentle-

$5 s$.

NTY.

ive more than iltum in prorro losest and the sely interested

$t$ the habits of here you may le justice in a

the minutest nging seenery h always give Poacher" and

ais lis minute 8 in a sceluied the author's Tinfs.

ne' \&e.

g wheat ficlds, here of art we CADKMY.

population of

of rural life

is last work of

ng so good lias

sesses a charm

finformation

ies, and of the

ce. 
